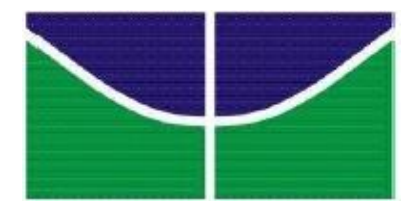

Universidade de Brasília

Faculdade de Educação

Programa de Pós-Graduação em Educação

INCLUSÃO DIGITAL DE PROFESSORES: Um olhar sobre a formação dos alunos do curso de Licenciatura em Pedagogia da Faculdade de Educação da Universidade de Brasília 
Diego Viana Porto

\title{
INCLUSÃO DIGITAL DE PROFESSORES: Um olhar sobre a formação dos alunos do curso de Licenciatura em Pedagogia da Faculdade de Educação da Universidade de Brasília
}

\begin{abstract}
Dissertação de mestrado apresentado ao Programa de Pós-Graduação em Educação da Universidade de Brasília como requisito parcial à obtenção do grau de Mestre em Educação, na linha de pesquisa Educação, Tecnologias e Comunicação sob orientação do Professor Dr. Gilberto Lacerda Santos.
\end{abstract}

Brasília - DF, 2016. 


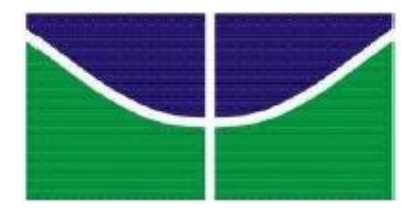

\section{Universidade de Brasília}

Faculdade de Educação

Programa de Pós-Graduação em Educação

\section{INCLUSÃO DIGITAL DE PROFESSORES: Um olhar sobre a formação dos alunos do curso de Licenciatura em Pedagogia da Faculdade de Educação da Universidade de Brasília}

Dissertação de Mestrado apresentada ao Programa de Pós-Graduação em Educação da Faculdade de Educação da Universidade de Brasília, como requisito parcial para obtenção do grau de Mestre em Educação, na linha de Pesquisa Educação, Tecnologias e Comunicação, aprovada em 14 de abril de 2016 pela Banca Examinadora constituída pelos professores: Prof. Dr. Gilberto Lacerda Santos (UnB) - Orientador e Presidente da Banca Examinadora; Profa. Dra. Lívia Freitas Fonseca Borges (UnB) - Avaliador Interno; Prof. Dr. Afonso Galvão (UCB) - Avaliador externo, e; Profa. Dra. Raquel de Almeida Moraes (UnB) - Avaliador suplente. 
Ficha catalográfica elaborada automaticamente, com os dados fornecidos pelo(a) autor(a)

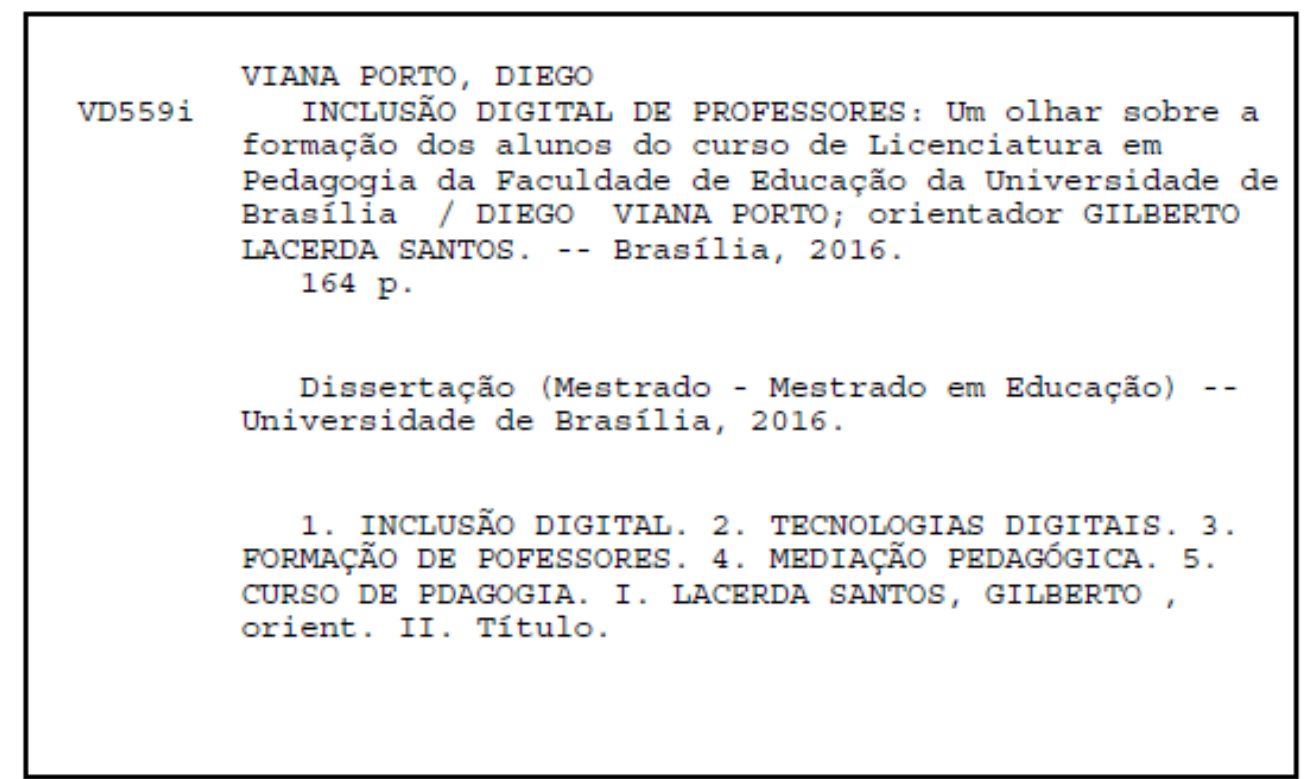




\section{AGRADECIMENTOS}

A Deus,

À minha família,

À Diretoria, Administrativos e Corpo Docente da Faculdade de Educação,

Ao meu Orientador Prof. Dr. Gilberto Lacerda Santos,

Aos meus amigos,

Aos meus colegas de curso e do grupo de pesquisa. 


\section{RESUMO}

Esta pesquisa teve como objetivo analisar se o Curso de Licenciatura em Pedagogia da Universidade de Brasília promove a inclusão digital de seus alunos, proporcionando uma atividade docente mediada pelas Tecnologias Digitais de Informação, Comunicação e Expressão e para uma sociedade cada vez mais digital. A investigação procurou estudar a função social de um curso de Pedagogia, o papel do professor face à Sociedade Digital, a formação de professores e sua importante missão na promoção da inclusão digital de seus alunos, além do próprio conceito de inclusão digital nesse contexto. Nessa perspectiva, a abordagem adotada foi a qualitativa, em um estudo de caso, no qual os instrumentos de geração de dados - a entrevista semiestruturada e o questionário - foram utilizados para subsidiar a análise crítica do produto gerado pelo curso de Licenciatura em Pedagogia da Universidade de Brasília, os acadêmicos finalizando o curso, os futuros professores. A pesquisa revela que as poucas oportunidades curriculares, a infraestrutura regular e a baixa propagação dos conceitos e conhecimentos pelos professores do curso em relação à temática estudada tornam muito difícil a aquisição, pelo aluno, de habilidades e conhecimentos necessários para sua inclusão digital e formação para possibilitar uma atividade docente mediada pelas TDICE visando à promoção da aprendizagem de seus futuros alunos.

Palavras-Chave: Inclusão digital; Tecnologias Digitais de Informação; Comunicação e Expressão; Formação de Professores; Curso de Pedagogia. 


\begin{abstract}
The aim of this research is to analyze if the Undergraduate Course in Licensing of Pedagogy of Brasilia University has been efficient at the promotion of digital inclusion for their students, providing them teaching activities guided by Digital Information Technology, Communication and Expression, and for an increasingly digital society. This investigation intended to study the social function of this Pedagogy Course; the teacher's role face the Digital Society; the formation of teachers, and their important mission to promote the digital inclusion of students, beyond the own concept of digital inclusion in this context. On this perspective, the qualitative approach was adopted in a case study, where the instruments of data collecting -the semi-structured interview and questionnaire- were used to subsidize the critical analysis of results by academics in a final stage of course, the future teachers. This research reveals that the little curricular opportunities, the regular infrastructure, the low propagation of concepts and knowledge by teachers of the course, in relation to the studied theme, turn up very difficult the acquisition by students. They don't have access to enough skills and knowledge required for theirdigital inclusion and formation to enable a teaching activity guided by TDICE, aiming the promotion of learning by future students..
\end{abstract}

Keywords: Digital Inclusion; Digital Information Technology; Communication and Expression; Formation of Teachers; Pedagogy Course. 


\section{LISTA DE GRÁFICOS}

Gráfico 1 - Gênero dos Alunos do Curso Presencial de Pedagogia .................................................. 69

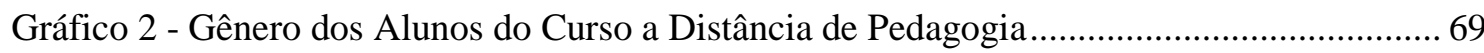

Gráfico 3 - Renda Familiar dos Alunos do Curso Presencial de Pedagogia ................................. 70

Gráfico 4 - Renda Familiar dos Alunos do Curso EAD de Pedagogia ......................................... 70

Gráfico 5 - Faixa Etária dos Alunos do curso Presencial de Pedagogia ...................................... 71

Gráfico 6 - Faixa Etária dos alunos do Curso a Distância de Pedagogia ...................................... 72

Gráfico 7 - Andamento dos Alunos no Curso Presencial de Pedagogia ....................................... 73

Gráfico 8 - Andamento dos Alunos no Curso a Distância de Pedagogia ...................................... 74

Gráfico 9 - Carreira de Docência: Alunos do Curso Presencial de Pedagogia.............................. 74

Gráfico 10 - Carreira de Docência: Alunos do Curso a Distância de Pedagogia ........................... 75

Gráfico 11 - Turma/Turno do Curso Presencial de Pedagogia..................................................... 75

Gráfico 12 - Alunos por Polos do Curso de Pedagogia a Distância................................................ 76

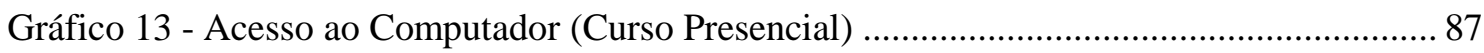

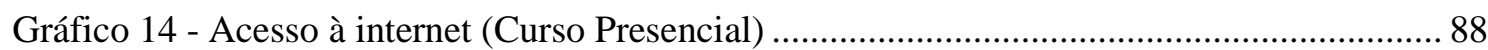

Gráfico 15 - Forma de Acesso ao Computador e Internet (Curso Presencial) ............................. 90

Gráfico 16 - Acesso aos Dispositivos Tecnológicos (Curso Presencial) ..................................... 90

Gráfico 17 - Acesso à Sala de Multimídia ou Videoconferência (Curso Presencial)................... 91

Gráfico 18 - Acesso aos Serviços On-line (Curso Presencial) .................................................... 93

Gráfico 19 - Estado de Conservação dos Equipamentos Tecnológicos (Curso Presencial)........ 93

Gráfico 20 - Acesso aos Dispositivos Tecnológicos e Digitais (EAD) ..................................... 95

Gráfico 21 - Forma de Acesso aos Computadores e Internet no Polo de Estudo (EAD) ............. 97

Gráfico 22 - Condição de Funcionamento dos Equipamentos Tecnológicos............................... 98

Gráfico 23 - Formação para Trabalhar com as TDICE (Presencial) ........................................ 101

Gráfico 24 - Formação para trabalhar com as TDICE (EAD) ............................................... 102

Gráfico 25 - Disciplina sobre a Teoria da Temática Educação e Tecnologias (Presencial)...... 103

Gráfico 26 - Disciplina sobre a Teoria da Temática Educação e Tecnologias (EAD) ............... 104

Gráfico 27 - Disciplina sobre a Prática da Temática Educação e Tecnologias (Presencial) ..... 105

Gráfico 28 - Disciplina sobre a Prática da Temática Educação e Tecnologias (EAD) .............. 107

Gráfico 29 - Necessidade da Disciplina sobre as TDICE na Graduação (Presencial) ............... 109

Gráfico 30 - Necessidade da Disciplina sobre as TDICE na Graduação (EAD) ........................ 109

Gráfico 31 - Cursou Alguma Disciplina a Distância (presencial) ........................................... 110

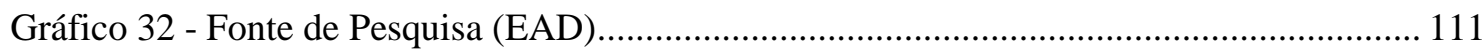

Gráfico 33 - Docência Mediada pelas TDICE (Presencial) ………....................................... 115

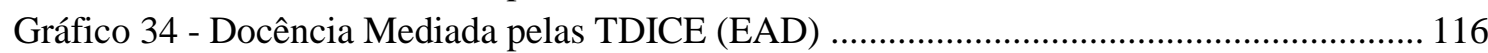

Gráfico 35 - Equipamentos digitais utilizados pelos professores (Presencial)........................... 117

Gráfico 36 - Equipamentos digitais utilizados pelos professores (EAD) .................................. 118

Gráfico 37 - Softwares Utilizados Mediante Demandas do Curso (Presencial).......................... 118

Gráfico 38 - Softwares Utilizados Mediante Demandas do Curso (EAD)................................ 119

Gráfico 39 - Softwares Utilizados para Comunicação com os Alunos (Presencial) .................. 119

Gráfico 40 - Softwares Utilizados para Comunicação com os Alunos (EAD) ........................... 120

Gráfico 41 - Finalidades Didático-pedagógicas das TDICE (Presencial) ................................... 121

Gráfico 42 - Finalidades Didático-pedagógicas das TDICE (EAD) ....................................... 123

Gráfico 43 - Tecnologias nas Salas de Aulas (Presencial) ........................................................ 128

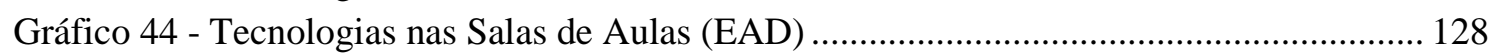

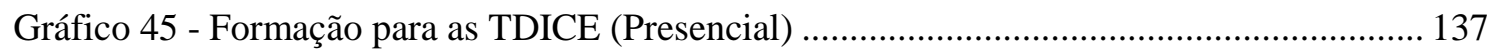

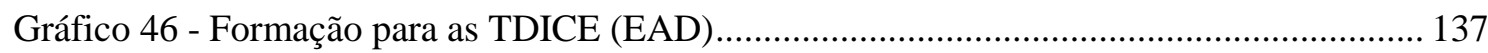

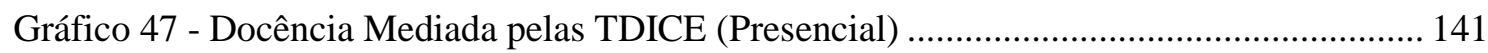

Gráfico 48 - Docência Mediada pelas TDICE (EAD) ............................................................... 141 


\section{LISTA DE SIGLAS}

ANFOPE - Associação Nacional pela Formação dos Profissionais da Educação

EAD - Educação a Distância

FE - Faculdade de Educação

LDB - Lei de Diretrizes e Bases da Educação Nacional

MEC - Ministério da Educação

PA - Projeto Acadêmico do Curso de Pedagogia

PPP - Projeto Pedagógico do Curso de Pedagogia

PROINFO - Programa Nacional de Informática na Educação

TDICE - Tecnologias Digitais da Informação, Comunicação e Expressão

TIC - Tecnologias da Informação e Comunicação

UNB - Universidade de Brasília 


\section{SUMÁRIO}

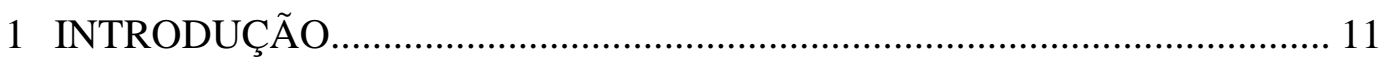

1.1 Trajetória da Pesquisa (motivação, experiências e observações)..... 16

1.2 Problema de Pesquisa.................................................................. 19

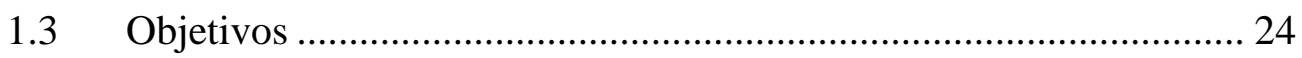

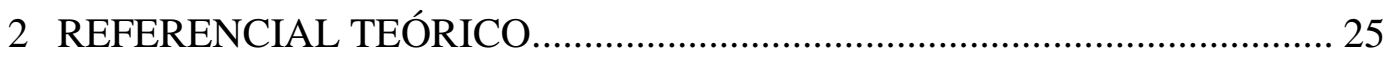

2.1 Educação, Tecnologias e Sociedade da Informação ......................... 26

2.2 Formação de Professores para a Sociedade da Informação .............. 30

2.3 Inclusão Digital de Professores ........................................................ 40

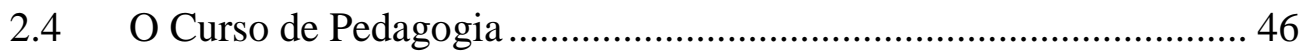

2.5 Breve Histórico da Formação dos Cursos de Pedagogia no Brasil ... 52

2.6 O Currículo e o Curso de Pedagogia da UnB.................................... 61

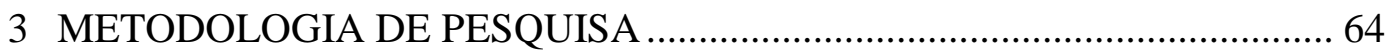

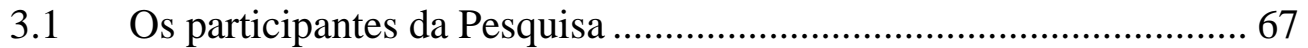

3.2 Instrumentos e Procedimentos para Geração de Dados .................... 76

3.2.1 Questionário ............................................................................. 76

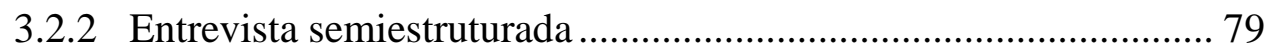

4 ANÁLISE DOS DADOS e discussão ......................................................... 82

4.1 Infraestrutura Tecnológica e Digital .............................................. 84

4.2 O Currículo do Curso de Pedagogia e as TDICE............................. 99

4.3 Os Docentes e as TDICE na Graduação.......................................... 113

4.4 TDICE na Sala de Aula ................................................................. 124

4.5 Docência Mediada pelas TDICE .................................................... 133

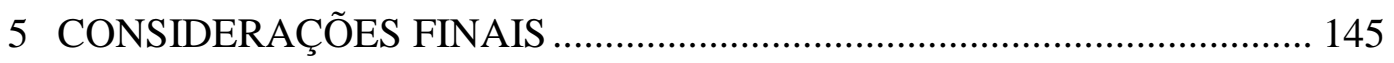

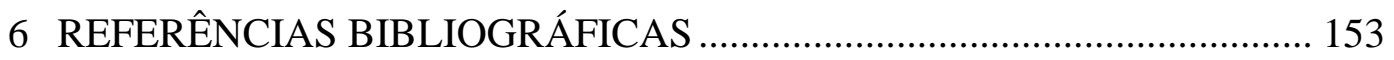

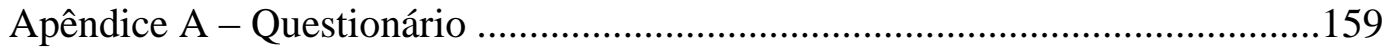

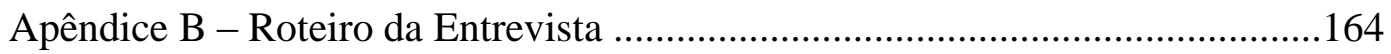

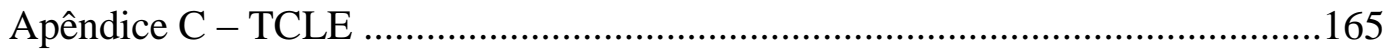




\section{INTRODUÇÃO}

O rápido e crescente desenvolvimento da Informática, a mudança cultural, o emprego de novas tecnologias, a alteração de valores e costumes, as alterações ambientais e comportamentais são de tal magnitude que as instituições educacionais e sociais não têm conseguido acompanhá-las. A educação tem necessidade de se adequar para atender a uma sociedade que se diverte, faz compras e estuda pelas redes de comunicação e internet. Enquanto a sociedade muda e experimenta desafios mais complexos, a educação formal continua, de maneira geral, organizada de modo previsível, repetitivo, burocrático, pouco atraente. Apesar de teorias avançadas, predomina, na prática, uma visão conservadora, repetindo o que está consolidado, o que não oferece risco nem grandes tensões (MORAN, 2013, p. 12). O autor defende que

A escola precisa reaprender a ser uma organização efetivamente significativa, inovadora, empreendedora. Ela é previsível demais, burocrática demais, pouco estimulante para os bons professores e alunos. Não há receitas fáceis nem medidas simples. Mas essa escola está envelhecida em seus métodos, procedimentos, currículos.

O ambiente educacional tem que se familiarizar com as transformações perante os avanços científicos e tecnológicos e assim constituir uma aprendizagem inovadora que leva o indivíduo a estar inserido na cultura digital. Em um mundo em constante mudança, a educação escolar tem de ser mais do que uma mera assimilação certificada de saberes, muito mais do que preparar consumidores ou treinar pessoas para a utilização das tecnologias de informação e comunicação.

A escola precisa assumir o papel de formar cidadãos para a complexidade do mundo e dos desafios que ele propõe. Preparar cidadãos conscientes, para analisar criticamente o excesso de informações e a mudança, a fim de lidar com as inovações e as transformações sucessivas dos conhecimentos em todas as áreas (KENSKI, 2012). Nesse cenário, é fundamental que a educação seja capaz também de responder às novas necessidades que se apresentam. Não se esquecendo da função social da educação formal, que é trazer ou disponibilizar para as novas gerações o conhecimento acumulado, necessário para a construção do presente e, sobretudo, do futuro. 
O professor precisa estar preparado para os novos e crescentes desafios desta geração que nunca esteve tão em contato com as Tecnologias Digitais de Informação, Comunicação e Expressão (TDICE) e fontes de acesso ao conhecimento. A formação inicial e a contínua atualização e aperfeiçoamento de professores é uma necessidade diante dos desafios e das mudanças rápidas que caracterizam a nossa sociedade. Segundo (GOMES, SILVA e NUNES, 2013, p. 71),

O docente sem base sólida na sua formação cultural, científica e pedagógica não tem tranqüilidade e firmeza para ensinar com os conhecimentos exigidos para os padrões da sociedade contemporânea".

A partir dos questionamentos iniciais, foi realizado um pré-levantamento bibliográfico com a finalidade de demarcar o objeto de investigação. Vários estudos foram desenvolvidos visando pesquisar as mudanças ocorridas em nossa sociedade em virtude das transformações impostas pelo avanço tecnológico (p. ex., GOMEZ, 2010; LÉVY, 2010; CASTELLS, 1999); a relação da educação frente às tecnologias (p. ex., KENSKI, 2012; MORAN, 2013; SANTOS, 2003; BELLONI, 2005); a formação de professores e sua inclusão digital (p. ex., FREITAS, 2010; CARVALHO NUNES, 2012; ALMEIDA, 2004; SILVA et al., 2005; SILVA, 2011; FERREIRA e LACERDA SANTOS, 2014; LACERDA SANTOS, 2010, 2014; BUZATO, 2003, 2007) e a função social e missão de um curso de Pedagogia (p. ex., PIMENTA, 2011; LIBÂNEO, 2010; SAVIANI, 2007, 2012). De uma forma geral, as pesquisas desenvolvidas apontam para a importância da inserção da educação nesta nova cultura digital. Realça-se a necessidade de o professor estar preparado para lidar com os novos e crescentes desafios desta geração que respira as TDICE. Marc Prensky denomina esta nova geração de "Nativos Digitais", os indivíduos que já nasceram imersos no mundo digital e que têm, cada dia mais cedo, aprendido e dominado os recursos digitais de forma veloz. Segundo Prensky (2001, p. 47),

Os alunos de hoje - do maternal à faculdade - representam as primeiras gerações que cresceram com esta nova tecnologia. Eles passaram a vida inteira cercados e usando computadores, vídeo games, tocadores de música digitais, câmeras de vídeo, telefones celulares, e todos os outros brinquedos e ferramentas da era digital. Em média, um aluno graduado atual passou menos de 5.000 horas de sua vida lendo, mas acima de 10.000 horas jogando vídeo games (sem contar as 20.000 horas assistindo à televisão). Os jogos de 
computadores, e-mail, a internet, os telefones celulares e as mensagens instantâneas são partes integrais de suas vidas.

Por outro lado, os professores, por não terem nascido ou se formado no contexto de tal efervescência tecnológica, precisam ser capacitados em serviço, enfrentando determinadas dificuldades, quais sejam: falta de tempo, turmas lotadas, deficiência no desenvolvimento pedagógico desde a universidade, ausência de equipamentos adequados na escola e formação continuada inadequada.

A necessidade de pesquisar a formação inicial de professores nas universidades emerge como uma continuidade dos estudos que tratam das temáticas que envolvem educação e tecnologias. A missão docente é um desafio permanente e de grande complexidade, devendo, no entanto, o professor ter uma formação inicial com solidez e uma contínua atualização. Especificamente em cursos de Pedagogia, nos quais o docente estará em contato com esta nova geração culturalmente digital, se torna muito importante uma formação apropriada do professor.

Observa-se que os cursos de formação de professores estão na ponta da execução de grandes e importantes políticas públicas de promoção da inclusão digital de docentes. Podemos citar o Projeto UCA, ProInfo, Programa Banda Larga nas Escolas, Tablet Educacional, TV Escola, Projetor Proinfo, e-Proinfo, etc. O MEC tem feito vários investimentos em políticas públicas visando à inclusão digital e formação dos professores para lidarem com as TDICE na escola. Para Braga e Lacerda Santos (2012, p. 12),

Sem o cidadão digitalmente incluído, todo projeto de desenvolvimento científico e tecnológico baseado no acesso à Sociedade da Informação tende à falência e à promoção de mais exclusão social. Assim sendo, a promoção da inclusão digital de todos deve ser encarada como um desafio do Estado, como um direito para o exercício pleno da cidadania.

A pesquisa em questão se desenvolveu a partir do estudo da formação dos alunos do curso de Pedagogia da Universidade de Brasília, com um olhar para a inclusão digital do pedagogo como base e possibilidade para uma docência mediada pelas novas tecnologias. Novas Tecnologias: são as tecnologias atualmente em evidência em nossa cultura, determinando nossa forma de agir, pensar, relacionar, 
trabalhar, estudar e divertir. Classificadas como tecnologias digitais (informática, dispositivos portáteis, aplicações, instrumentos, internet, computadores, etc.).

O curso de Pedagogia da Universidade de Brasília, em seu projeto acadêmico, aponta que o futuro dos sistemas de educação e da formação deve necessariamente se apoiar numa análise da mutação recente da relação com o saber em função da quantidade e da velocidade dos saberes produzidos e da capacidade de renová-los. Relata que, pela primeira vez no curso do desenvolvimento da humanidade, a maioria das competências adquiridas por uma pessoa a iniciar sua vida profissional se tornará obsoleta bem antes de chegar ao final de sua carreira. Acoplada a essa constatação está a nova natureza do trabalho, que faz com que trabalhar signifique cada vez mais aprender, compartilhar saberes e produzir conhecimentos.

O projeto acadêmico do curso de Pedagogia da UNB ainda reconhece que as tecnologias da comunicação e da informação ampliaram consideravelmente e alteraram muitas funções cognitivas humanas, além do uso que tinha sido feito da memória, da instrução, da percepção, do raciocínio, etc. Com isso, informações e conhecimentos podem ser produzidos e compartilhados entre um grande número de indivíduos, aumentando assim o potencial de inteligência coletiva dos grupos humanos e modificando profundamente a noção de tempo e espaço na educação e na formação, e sobretudo introduzindo o conceito de comunidade de aprendizagem em rede.

Será que o curso de Pedagogia da Universidade de Brasília, conforme documentos oficiais, Projeto Acadêmico e Projeto Político Pedagógico do curso de Pedagogia da Universidade de Brasília, promove a inclusão digital de seus alunos, proporcionando ensinamentos para uma atividade docente mediada pelas novas tecnologias e para uma sociedade digital? Uma interrogação foi lançada sobre o processo de formação de professores para uma sociedade informatizada e conectada às redes de comunicação. O desafio das universidades se consolida em formar os profissionais incluídos digitalmente para atuarem na sociedade da informação. Percebeu-se, então, a necessidade de investigar se o curso de Pedagogia da Universidade de Brasília promove a inclusão digital de seus alunos, futuros professores. 
A expressão "sociedade da informação" passou a ser utilizada como substituto para o conceito complexo de "sociedade pós-industrial" e como forma de transmitir o conteúdo específico do "novo paradigma técnico-econômico". A realidade que os conceitos das ciências sociais procuram expressar refere-se às transformações técnicas, organizacionais e administrativas que têm como "fator-chave" não mais os insumos baratos de energia - como na sociedade industrial - mas os insumos baratos de informação propiciados pelos avanços tecnológicos na microeletrônica e nas telecomunicações. Essa sociedade pós-industrial ou "informacional", como prefere Castells, está ligada à expansão e reestruturação do capitalismo desde a década de 80 do século que terminou. As novas tecnologias e a ênfase na flexibilidade - ideia central das transformações organizacionais - têm permitido realizar com rapidez e eficiência os processos de desregulamentação, privatização e ruptura do modelo de contrato social entre capital e trabalho característicos do capitalismo industrial (WERTHEIN, 2000).

O avanço da tecnologia da informação vem mudando o ensino e a maneira como se aprende. E, provavelmente, vai continuar a mudá-lo, seja buscando integração de mídias com o ensino tradicional, seja substituindo ferramentas tradicionais de ensino por aparatos tecnológicos, ou mesmo utilizando os meios eletrônicos como forma de levar a educação a lugares de difícil acesso. Freitas (2010, p. 349) ressalta que para formar futuros professores para o trabalho com nativos digitais, faz-se necessário enfrentar a responsabilidade de uma constante atualização, a defasagem entre o seu letramento digital e o do aluno, e manter o distanciamento possibilitador de um olhar crítico diante do que a tecnologia digital oferece.

Torna-se, então, muito importante ter uma formação inicial que proporcione a inclusão digital do professor. A necessidade da promoção de ações de inclusão digital específicas para professores surge, dentre outras coisas, da compreensão de que a sociedade da informação é espaço para reflexão acerca das necessidades evidentes de democratização do acesso aos recursos informáticos, de um projeto de educação libertadora e particularmente de formação de professores para o uso crítico e criativo da informática na educação (LACERDA SANTOS, 2003, p. 9). 
Esta pesquisa se propõs a analisar se o curso de Pedagogia da Universidade de Brasília promove a inclusão digital de seus alunos, proporcionando uma atividade docente mediada pelas TDICE e para uma sociedade cada vez mais digital. Implicando estudar a função social de um curso de Pedagogia, o papel do professor face à Sociedade Digital, sua importante missão na promoção da inclusão digital de seus alunos, além do próprio conceito de inclusão digital nesse contexto.

Para tanto, passou-se ao estudo dos aspectos envolvidos na pesquisa por meio de um vasto levantamento documental para a compreensão do papel do professor enquanto mediador de inclusões digitais. De modo que a abordagem adotada será a qualitativa, em um estudo de caso, no qual os instrumentos de geração de dados, a entrevista semiestruturada e o questionário serão utilizados para subsidiar a análise crítica do produto gerado pelo curso de Pedagogia da Universidade de Brasília, acadêmicos finalizando o curso, os futuros professores.

\subsection{Trajetória da Pesquisa (motivação, experiências e observações)}

Desde quando cursava o ensino médio, juntamente com o curso técnico em agropecuária (2003), eu ficava impressionado ao observar como o emprego da tecnologia conseguia aumentar a produtividade e a eficiência no segmento onde era empregada. Observava como era possível maximizar o desempenho em determinadas tarefas adotando artefatos tecnológicos mais desenvolvidos. Tive clara a ideia de que independentemente da atividade que fosse desenvolver poderia, de alguma forma, ter vários benefícios empregando uma tecnologia ou técnica para o fim proposto.

Vislumbrando o avanço tecnológico e a difusão maciça da informática e internet, cursei um curso técnico em informática (2005), a partir do qual surgiu a oportunidade de trabalhar juntamente com professores quando fui aprovado em um concurso no cargo de técnico de tecnologia da informação no então Centro Federal de Educação Tecnológica de Januária (2007), atualmente Campus do Instituto Federal de Educação, Ciência e Tecnologia do Norte de Minas Gerais. Na oportunidade atuava como suporte ao setor de ensino da instituição, tendo como tarefas, principalmente, a manutenção em laboratórios de informática, nas redes de computadores e internet, 
manutenção e configuração de computadores e impressoras. O que me chamou atenção, na época, era a dificuldade que os docentes tinham para lidar com os aparatos tecnológicos, computadores e internet. Como atuava próximo aos professores no setor de ensino da instituição, sempre era requisitado para alguma tarefa com o intuito de ajudar os docentes e o serviço pedagógico em alguma atividade específica. Ali percebi que a classe de professores, de uma forma geral, não tinha sido formada para lidar com as tecnologias que se consubstanciavam.

Ao ingressar no curso superior na área de Informática, Análise e Desenvolvimento de Sistemas (2007) pude conhecer e trabalhar com uma grande quantidade de ferramentas e aplicações que potencializavam o ensino-aprendizagem. Começava a imaginar como poderia ser útil uma prática docente mediada pelas tecnologias e, sobretudo, pelo computador e internet. Sentia que as aulas poderiam ser mais produtivas se pudéssemos contextualizá-las com algumas aplicações e/ou ferramentas tecnológicas. Como seria interessante estudar geografia e poder utilizar o Google Erth, ou trabalhar com geometria e utilizar um software em 3D, desenvolver uma didática para a disciplina de artes utilizando um software como o Corel Draw, ou trabalhar a expressão dos alunos com o emprego dos blogs, redes sociais, etc.

Finalizando o curso superior, ingressei como aluno em uma especialização em Tecnologias Educacionais (2009) para conhecer mais sobre a influência das tecnologias na educação, as potencialidades, os desafios, as teorias, etc. Com os conhecimentos adquiridos passei a ter uma visão mais ampla e especializada da temática tecnologia + educação. Cheguei a cursar outra especialização, agora em Educação a Distância (2012), que é uma modalidade de ensino que tem relacionamento muito estreito com a tecnologia e cada vez mais me convencia de que a aproximação das tecnologias com a educação, com propósito e objetivos bem definidos, seria benéfica, desejável e imprescindível.

Quando já tinha finalizado o curso superior na área de informática e cursado a especialização em Tecnologias Educacionais, prestei concurso para a carreira docente (2010) e atuo até hoje como professor no Instituto Federal de Educação, Ciência e Tecnologia do Norte de Minas Gerais no Campus Arinos. Como professor, realizei experiências com as TDICE que imaginava poder agregar valor às aulas. Logo percebi 
que ao empregar uma tecnologia, envolver o computador ou internet, os alunos ficavam mais motivados e animados para as tarefas que seriam desenvolvidas. Buscava, de certa forma, fazer com que as tecnologias ajudassem na contextualização do conteúdo que fôssemos trabalhar.

Em experiências e também observando colegas em atuação, percebia que a tecnologia, o computador e a internet por si só não elevavam a um patamar maior a aprendizagem que estava sendo desenvolvida. A falta de planejamento e definições de propósito e objetivos bem delimitados acabavam por acarretar um rendimento não satisfatório do emprego de uma determinada ferramenta/aplicação, e em muitos dos casos aquela ferramenta ou aplicação acabava atrapalhando o processo de aprendizagem por não ter bem delimitado o objetivo/propósito de sua utilização.

Com o passar do tempo observei a facilidade que os alunos do ensino básico tinham de lidar com as tecnologias, ao contrário de muitos dos educadores. Eles pareciam já estar habituados com os aparatos tecnológicos e demonstravam uma facilidade muito grande de aprender como trabalhar com eles. Cada vez mais sentia que, pela forma de atuação dos professores, da escola e do sistema de ensino, estávamos ficando distantes dos alunos por não contemplarmos, na escola, alguns de seus aspectos culturais, principalmente quando ouvia, em reuniões pedagógicas, que teríamos que proibir qualquer tipo de aparelho digital ou tecnológico em sala de aula ou que os professores não gostavam de trabalhar com computadores/internet.

Participei de alguns cursos de formação de professores visando à inclusão digital e percebi de perto as dificuldades e anseios da classe em geral em relação ao trabalho e utilização das tecnologias na escola. Notava-se a dificuldade de grande parte dos docentes em lidar com ferramentas e equipamentos de uma área para a qual eles não foram preparados e observava neles uma grande vontade de aprender a manusear, compreender e utilizar as tecnologias no ambiente escolar e em casa para auxílio às atividades pedagógicas.

Percebia um imenso potencial que a inserção e aproximação das TDICE à educação nos possibilitava enquanto educadores, haja vista as inesgotáveis fontes de pesquisa, aplicações, softwares, ferramentas tecnológicas, etc., mas também a falta de 
preparo dos professores para lidarem com as TDICE e com o novo perfil de aluno e a forma como o ensino ainda é propagado nas escolas, tendo o professor como centralizador, sujeito ativo no processo de aprendizagem, e os alunos com postura passiva, a falta de oportunidade para os alunos se expressarem, um ensino tradicional industrial para um público novo, que se sentia deslocado e desmotivado com a escola e a educação.

Ao ingressar no programa de mestrado, acompanhei de perto várias discussões acerca da formação de professores para atuação na sociedade da informação. Várias indagações surgiam em relação à formação que a própria Faculdade de Educação da UNB estava proporcionando aos seus alunos do curso de Pedagogia.

Observando a representatividade do curso de Pedagogia da UNB, seu alcance nacional servindo de referência na formação de professores no país e também a particularidade de que o profissional formado como pedagogo atua perante um público jovem que possui uma sintonia muito grande com as TDICE, percebe-se o quanto é importante esse profissional ter uma formação que lhe proporcione uma didática mediada pelas TDICE, para um público culturalmente imerso na cultura digital, condizente com a sociedade da informação e que possibilite sua atuação na inclusão digital de seus alunos e os guie perante os bits e bytes propagados em meio à cibercultura. Pois, alunos sem acesso contínuo às redes digitais estão excluídos de uma parte importante da aprendizagem atual: do acesso à informação variada e disponível on-line, da pesquisa rápida em bases de dados, bibliotecas digitais, portais educacionais; da participação em comunidades de interesse e debates e publicações on-line, enfim, da variada oferta de serviços digitais (MORAN, 2010, p. 9).

\subsection{Problema de Pesquisa}

O professor precisa se formar no uso pedagógico das TICs, a fim de aperfeiçoar sua ação docente no letramento dos alunos. Ele precisa transcender o espaço físico e tangível do livro impresso para adentrar, sem medo, o universo do imaterial e virtual, apreendendo distintas formas de leitura e escrita (GOMES, SILVA e NUNES, 
2013, p. 79). A formação docente precisa estar atualizada com o desenvolvimento cultural, social e econômico de nossa sociedade. Kenski (2012, p. 106) cita que

\begin{abstract}
A formação de qualidade dos docentes deve ser vista em um amplo quadro de complementação às tradicionais disciplinas pedagógicas e que inclui, entre outros, um razoável conhecimento de uso do computador, das redes e de demais suportes midiáticos (rádio, televisão, vídeo, por exemplo) em variadas e diferenciadas atividades de aprendizagem. É preciso saber utilizá-los adequadamente. Identificar quais as melhores maneiras de utilizar as tecnologias para abordar um determinado tema ou projeto específico ou refletir sobre eles, de maneira a aliar as especificidades do "suporte" pedagógico (do qual não se exclui nem a clássica aula expositiva nem, muito menos, o livro) ao objetivo maior da qualidade de aprendizagem de seus alunos.
\end{abstract}

Observa-se o grande investimento que o governo federal vem fazendo na educação e formação de professores por intermédio de políticas públicas para a formação e atualização docente. Do outro lado desta história estão as faculdades de educação que proverão a formação dos futuros professores. Levando-se em consideração a importância da adequação da educação à sociedade da informação e o investimento de políticas públicas para este fim, nos falta perguntar como tem sido conduzida a formação dos docentes que atuarão e serão responsáveis por propagarem a inclusão digital perante seus alunos.

O projeto acadêmico do curso de Pedagogia da Universidade de Brasília relata a preocupação com a formação de um profissional para um mundo globalizado e atualizado com as mudanças originadas da reestruturação do mercado de trabalho. Nele é ressaltado que a crescente incorporação da ciência e da tecnologia aos processos produtivos e sociais advinda da globalização da economia provocou uma reestruturação do mundo de trabalho em escala planetária. Relata que ao passar de uma base eletromecânica para uma base microeletrônica que atingiu todos os setores da vida social e produtiva nas últimas décadas, o sistema produtivo alterou a relação entre educação e trabalho. Assim, passou-se a exigir que não somente se amplie a base do conhecimento do trabalhador, mas que ele viesse a possuir habilidades cognitivas, comportamentais e tecnológicas diferentes das exigidas pelos modos de fazer vigentes na era do fordismo/ taylorismo (UNB, 2002). 
O projeto acadêmico do curso ainda traz como um desafio o compromisso de formar profissionais para a atuação pedagógica mediada pelas tecnologias em meio à sociedade da informação e do conhecimento.

Um desafio complementar no novo currículo é o da formação para e pelo uso das tecnologias da informação e da comunicação (TIC) em educação. É uma resposta que cabe à Faculdade de Educação realizar, fiel à sua missão, formando educadores na sociedade da informação e do conhecimento (UNB, 2002).

Para conseguir vencer este desafio de formar pedagogos aptos a um mercado de trabalho globalizado, reestruturado e em rede, o projeto acadêmico do curso prevê que a formação deverá se iniciar com uma compreensão do papel da tecnologia na evolução das sociedades para chegar a entender como ela faz parte do processo de desenvolvimento cultural no mundo moderno. Essa visão deverá permear todo o curso e se concretizar em duas modalidades distintas: nas Oficinas de Comunicação e Tecnologia e na vivência das tecnologias interativas on-line, resultado da incorporação de tais tecnologias ao processo de formação e de aprendizagem, tirando partido da flexibilização dos tempos e espaços propiciada pelas TIC. Esta formação, oferecida em Oficinas e Seminários e o mais possível vivenciada em todos os espaços curriculares, deverá ser alcançada tanto teórica quanto vivencialmente.

No projeto político-pedagógico do curso de Pedagogia da UNB é apresentado um plano de desenvolvimento e implantação de gestão da tecnologia de informação, visando atender aos processos que demandam das universidades novas formas de gestão da educação superior tendo em vista as especificidades das tecnologias da informação e comunicação aplicadas a contextos educativos, que possibilitou a aquisição de equipamentos e software para a modernização do aparato tecnológico, e dessa forma possibilitando:

1- Modernização do ambiente de aprendizagem com o uso de recursos visuais (data-show, TV, etc.), internet (FE Wireless), laboratórios, webmail próprio, várias plataformas Moodle, portal institucional, sistemas de automatização de rotinas (reservas de salas e solicitação de cópias via web), biblioteca virtual, suporte permanente aos recursos tecnológicos e aos usuários. 
2- Disponibilização de notebook para professores.

No projeto político-pedagógico é ressaltado, entretanto, que para atender à demanda crescente em torno de atividades que requerem o uso das TIC, faz-se necessário ampliar a infraestrutura tecnológica da Faculdade de Educação, de modo a contemplar ações de: avaliações de desempenho acadêmico; estágios obrigatórios previstos na legislação pertinente para os alunos a distância; defesas de trabalho de conclusão de curso em conformidade com a legislação pertinente também para os alunos a distância; atividades de laboratório de ensino, previstas nos projetos pedagógicos dos cursos; pesquisa. Uma projeção inicial dessa ampliação prevê:

1- Iniciar um debate com todos os professores e alunos sobre a visão estratégica da FE em relação às novas tecnologias e sua utilização no processo de ensino-aprendizagem, e a partir dessa discussão estabelecer metas quanto à infraestrutura da rede informática da FE, assim como da formação dos professores e funcionários para seu uso eficiente;

2- Reestruturar a rede elétrica, que atualmente encontra-se totalmente defasada, impossibilitando os demais avanços;

3- Elevar a quantidade e autonomia de funcionamento dos servidores de rede, switch's, router's e access point's em caso de falta de energia;

4 - Modernizar e substituir os equipamentos obsoletos no laboratório de administração da rede e estações de trabalho;

5 - Dotar os laboratórios de ensino de graduação com equipamentos modernos, com melhores níveis de sensibilidade, com maior velocidade de processamento, etc., de modo a tornar mais eficiente o ambiente de ensino-aprendizagem, no que diz respeito ao desenvolvimento das atividades práticas;

6 - Dotar as salas de aula com equipamentos e condições necessárias à apresentação de aulas com maior eficiência e conforto para professores e estudantes, mediante a disponibilização de espaço físico apropriado, com boa iluminação e 
ventilação e com equipamentos necessários à apresentação de aulas usando recursos tais como conexão à internet, "data-show", telas de projeção, bons quadros-negros, mobiliário adequado e outros instrumentos;

7 - Ampliação e criação de novas salas de aprendizagem eletrônica, destinadas aos alunos dos cursos de graduação, equipadas com computadores, impressoras e outros acessórios necessários à aprendizagem eletrônica de modo a permitir que professores e estudantes façam uso de um conjunto de ferramentas, tais como softwares e plataformas de aprendizagem, em um ambiente eletrônico que permita o pleno desenvolvimento das atividades de ensino-aprendizagem (UNB, 2012).

Diante do reconhecimento da necessidade de se adequar e atualizar a estrutura, o currículo e a concepção perante a sociedade da informação e do conhecimento, nos resta saber se o curso de Pedagogia da Universidade de Brasília promove a inclusão digital de seus alunos, proporcionando ensinamentos para uma atividade docente mediada pelas novas tecnologias e para uma sociedade cada vez mais digital.

Marilda Aparecida Behrens afirma que o advento da economia globalizada e a forte influência dos avanços dos meios de comunicação e dos recursos de informática aliados à mudança de paradigmas da ciência não comportam um ensino nas universidades que se caracterize por uma prática pedagógica conservadora, repetitiva e acrítica. Ressalta também que:

As exigências de uma economia globalizada afetam diretamente a formação dos profissionais em todas as áreas do conhecimento. Tornase relevante alertar que o profissional esperado para atuar na sociedade contemporânea exige hoje uma formação qualitativa diferenciada do que se tem ofertado em um grande número de universidades (BEHRENS, 2013, p. 75).

Uma interrogação foi lançada sobre o processo de formação de professores para uma sociedade informatizada e conectada às redes de comunicação. $\mathrm{O}$ desafio das universidades se consolida em formar os profissionais incluídos digitalmente para atuarem na sociedade da informação. Percebeu-se, então, a necessidade de se investigar se o curso de Pedagogia da Universidade de Brasília promove a formação de seus alunos, futuros professores, para uma docência mediada pelas TDICE. Algumas 
questões podem ser inferidas para se questionar a formação dos pedagogos da Universidade de Brasília:

- Qual o envolvimento existente entre os alunos do curso de Pedagogia da Universidade de Brasília com as TDICE em sua formação?

- Como eles percebem a inserção das TDICE na sala de aula? Eles conhecem as possibilidades da utilização das tecnologias no processo de ensino e aprendizagem?

- Eles se sentem confortáveis e capazes de proporcionar situações educativas mediadas pelas TDICE com seus alunos?

\subsection{Objetivos}

Este dissertação foi delineada como um estudo qualitativo, no qual ocorreu um levantamento de dados com os alunos finalizando o curso de Pedagogia da UNB sobre a sua formação, com o propósito de buscar a percepção destes acadêmicos acerca de sua inclusão digital e aptidão para uma atividade docente mediada pelas TDICE. Neste sentido, a seguir, apresentam-se os seguintes objetivos que delimitam a presente pesquisa.

Objetivo Geral: Analisar se o Curso de Licenciatura em Pedagogia da Universidade de Brasília proporciona aos seus alunos uma formação que possibilite uma docência mediada pelas TDICE.

Objetivos Específicos: Identificar o envolvimento dos alunos do curso de Pedagogia com as TDICE em sua formação; observar qual a percepção dos alunos do curso de Pedagogia em relação à inserção das TDICE na sala de aula; perceber se os alunos se sentem preparados para uma docência mediada pelas TDICE, sobretudo no processo de ensino-aprendizagem. 


\section{REFERENCIAL TEÓRICO}

Para compreensão dos aspectos envolvidos com o objetivo da dissertação, foi proposto o estudo teórico para servir de base ao alcance do entendimento das dimensões que compõem a temática a ser explorada. Poderão ser encontradas pela dissertação várias definições e expressões para caracterizarem as novas tecnologias que são utilizadas e difundidas em grande escala em nosso dia a dia e sociedade.

Para Lacerda Santos (2014), o conceito de TDICE, em plena evolução, reflete o momento de efervescência cultural em que nos encontramos. Quando as TDICE, decorrentes da Informática, surgiram e foram, de uma forma ou de outra, aplicadas a contextos educativos, eram simplesmente designadas como TE (Tecnologias Educativas). Em seguida, se percebeu que eram mais do que TE, conceito que envolvia todo tipo de tecnologias materiais e intelectuais usadas para fins pedagógicos, incluindo as mais convencionais. Passou-se a empregar o acrônimo TIC, o qual designa exclusivamente as Tecnologias de informação e comunicação (TIC), as quais são uma categoria das TE. Em seguida, notou-se que TIC também era uma sigla muito abrangente, especialmente no que se referia à natureza digital de tais tecnologias. Passou-se, assim, a empregar o $\mathrm{N}$ de "novas", para distingui-las das "velhas", como a $\mathrm{TV}$, o retroprojetor e o rádio.

Em meados dos anos 90, integra-se a letra $\mathrm{E}$ à sigla, tendo em vista a construção da percepção de que um dos diferenciais mais importantes de tais tecnologias está na possibilidade de livre expressão que elas permitem, por meio dos dispositivos da internet 2.0. Contudo, diversos pesquisadores ainda percebem a necessidade de melhor especificação do conceito. Por se tratar das TDICE, vários autores passaram a incluir a letra D e a usar o acrônimo TDICE, o qual designa as Tecnologias Digitais da Informação, Comunicação e Expressão (LACERDA SANTOS, 2014).

O termo novas tecnologias expresso na dissertação se refere às Tecnologias Digitais da Informação, Comunicação e Expressão (TDICE), que são assim definidas por Lacerda Santos (2014, p. 530), por promoverem a convergência de todas as mídias e 
por serem suportes privilegiados e inovadores para que nos informemos com mais intensidade, nos comuniquemos com mais agilidade e nos expressemos com mais liberdade. As "TDICE” são oriundas das Ciências da Computação, as quais, cada vez mais, têm influenciado a forma da sociedade se desenvolver.

\subsection{Educação, Tecnologias e Sociedade da Informação}

Nesses tempos acelerados em que as informações circulam freneticamente aparecendo e desaparecendo antes de serem compreendidas e apropriadas, a escola, contrariamente ao que por vezes se acredita, torna-se ainda mais necessária como agência encarregada de possibilitar às novas gerações o acesso ao conhecimento sistematizado produzido pela humanidade ao longo da história. Segundo Saviani (2012),

[...] a escola não pode, também ela, surfar nas ondas do imediatismo, das informações dispersas e na superficialidade dos estímulos multifacetados e dos apelos midiáticos. Em lugar disso cabe-lhe propiciar o acesso ao conhecimento que é mais do que informação. Conhecimento significa compreender as relações entre os fenômenos, entender como a realidade se processa, como a sociedade se organiza, como os homens se relacionam entre si. Conhecimento é, pois, compreensão de relações e o simples acesso às informações não garante isso.

A partir do conhecimento sistematizado, propiciado pela educação escolar, as crianças e jovens poderão se mover com segurança no universo das informações processando-as adequadamente, discriminando entre as falsas e as verdadeiras e diferenciando entre o que é e o que não é relevante (SAVIANI, 2012).

Passamos por transformações em nossa sociedade que demandam uma reestruturação de nosso sistema de ensino e educação. Vivenciamos uma época em que a colaboração, a interatividade e o acesso à informação se fazem presentes cotidianamente na vida das pessoas. Para Castells (1999, p. 565), as funções e os processos dominantes na era da informação estão cada vez mais organizados em torno de redes. As redes constituem a nova morfologia social de nossas sociedades e a difusão da lógica de redes modifica de forma substancial a operação e os resultados dos processos produtivos e de experiência, poder e cultura. Embora a forma de organização social em redes tenha existido em outros tempos e espaços, o novo paradigma da 
tecnologia da informação fornece a base material para sua expansão penetrante em toda a estrutura social. $\mathrm{O}$ autor afirma que

[...] a convergência da evolução social e das tecnologias da informação criou uma nova base material para o desempenho de atividades em toda a estrutura social. Essa base material construída em redes define os processos sociais predominantes, conseqüentemente dando forma à própria estrutura social (CASTELLS, 1999, p. 567).

Segundo Castells (1999, p. 119), uma nova economia surgiu em escala global no último quartel do século XX. Ele a chama de informacional, global e em rede para identificar suas características fundamentais e diferenciadas e enfatizar sua interligação.

[...] é informacional porque a produtividade e competitividade de unidades ou agentes nessa economia (sejam empresas, regiões ou nações) dependem basicamente de sua capacidade de gerar, processar e aplicar de forma eficiente a informação baseada em conhecimentos. É global porque as principais atividades produtivas, o consumo e a circulação, assim como seus componentes (capital, trabalho, matériaprima, administração, informação, tecnologia e mercados) estão organizados em escala global, diretamente ou mediante uma rede de conexões entre agentes econômicos. É rede porque, nas novas condições históricas, a produtividade é gerada, e a concorrência é feita em uma rede global de interação entre redes empresariais.

A economia global fez surgir regras econômicas em comum em todo o mundo. Em meio aos três pilares (economia, sociedade e cultura), existe uma redefinição nas relações produtivas de poder e experiência. Essas relações de produção transformaramse numa forma de capitalismo informacional e para que elas sejam entendidas se faz necessária a análise do processo produtivo, do trabalho e do capital. Graças às novidades trazidas pela era tecnológica, ocorreu uma difusão de culturas pelo mundo, tornando-o cada vez mais virtualizado, isso porque o espaço-tempo foi encurtado, fazendo com que aumentasse a velocidade da informação passada.

Castells (1999, p. 462) expõe que o novo sistema de comunicação criado pelo avanço tecnológico transforma radicalmente o espaço e o tempo, dimensões fundamentais da vida humana. Localidades ficam despojadas de seu sentido cultural, histórico e geográfico e reintegram-se em redes funcionais ou em colagens de imagens, ocasionando um espaço de fluxos que substitui o espaço de lugares. O tempo é apagado no novo sistema de comunicação já que passado, presente e futuro podem ser 
programados para interagir entre si na mesma mensagem. O espaço de fluxos e o tempo intemporal são as bases principais de uma nova cultura, que transcende e inclui a diversidade dos sistemas de representação historicamente transmitidos: a cultura da virtualidade real, no qual o faz-de-conta vai se tornando realidade.

A interconexão, as comunidades virtuais e a inteligência coletiva seriam, de acordo com Lévy (2010), os princípios que regem esta nova cultura, "a cibercultura". O ciberespaço e a cibercultura foram determinantes para o surgimento de novas formas de sociabilidade, novas organizações e novas formas de manifestações sociais e culturais. O que caracteriza a atual revolução tecnológica não é a centralidade de conhecimentos e informação, mas a aplicação desses conhecimentos e dessa informação para a geração de conhecimentos e de dispositivos e de processamento/comunicação da informação, em um ciclo de realimentação cumulativo entre a inovação e seu uso (CASTELLS, 1999, p. 69).

Gomez (2010, p. 16) elucida que assim como os jornais, as revistas, o rádio, o telefone, a TV, os filmes e os DVDs são produtos de uma cultura e geram cultura e sociabilidade em seu entorno, a internet, como um artefato cultural, tem gerado a cibercultura, produto de uma relação de trocas entre a sociedade, a cultura e as novas tecnologias de base microeletrônica graças à convergência das telecomunicações com a informática. Kenski (2012, p. 22) observa que

[...] na atualidade, o surgimento de um novo tipo de sociedade tecnológica é determinado principalmente pelos avanços das TDICE de comunicação e informação e pela microeletrônica. Essas novas tecnologias, assim consideradas em relação às tecnologias anteriormente existentes, quando disseminadas socialmente, alteram as qualificações profissionais e a maneira como as pessoas vivem cotidianamente, trabalham, informam-se e se comunicam com outras pessoas e com todo o mundo.

A educação tem a missão de se adequar para contemplar e atender a uma sociedade que se diverte, faz compras e estuda pelas redes de comunicação e internet. Costumes estes que formam um novo perfil para o aluno que já nasce em meio à tecnologia e conectividade. Belloni (2005, p. 69) nos alerta que o avanço tecnológico no campo das comunicações torna indispensável e urgente que a escola integre esta nova 
linguagem audiovisual - que é a linguagem dos alunos - sob pena de perder o contato com as novas gerações.

O desafio das políticas públicas se consolida em formar os profissionais para atenderem esta demanda por uma educação inclusiva e pautada na utilização da grande quantidade de informações disponíveis para uma constituição de conhecimento embasado na reflexão e crítica. Belloni (2005, p. 10) defende que

A escola deve integrar as tecnologias de informação e comunicação porque elas já estão presentes e influentes em todas as esferas da vida social, cabendo à escola, especialmente à escola pública, atuar no sentido de compensar as terríveis desigualdades sociais e regionais que o acesso desigual a estas máquinas está gerando.

Kenski (2012, p. 38) deixa claro que as novas TICs não são apenas meros suportes tecnológicos. Elas têm suas próprias lógicas, suas linguagens e maneiras particulares de comunicar-se com as capacidades perceptivas, emocionais, cognitivas, intuitivas e comunicativas das pessoas.

A educação tem que estar inserida nesse novo contexto de automação do conhecimento, almejando uma aprendizagem significativa por meio de tecnologias. $\mathrm{O}$ ambiente educacional tem que se familiarizar com as transformações frente a esse novo paradigma educacional tecnológico e assim constituir uma aprendizagem inovadora que leva o indivíduo a se sentir como um ser globalizado.

Kenski (2012, p. 59) observa que as escolas não têm verba suficiente para manutenção e atualização permanentes dos programas e realização de treinamentos para todo o pessoal pedagógico e administrativo do estabelecimento. É preciso que verbas cada vez maiores sejam previstas nos orçamentos para esses itens, além da aquisição de novas máquinas e novos programas. Esses são apenas os problemas iniciais na relação entre as escolas e o uso das TDICE. Segundo Belloni (2005, p. 87),

O avanço tecnológico tende a aprofundar as desigualdades tanto entre as nações como entre as classes sociais. Enquanto as escolas particulares investem na informatização, colocando à disposição dos alunos aparelhos sofisticados e exigindo dos professores que se preparem, na escola pública isto é considerado um luxo. 
É evidente que a escola tem um papel crucial nos processos de inclusão digital dos cidadãos, desenvolvendo junto a todos as competências, habilidades e conhecimentos necessários para seu uso irrestrito, responsável, mobilizador e autonomista das NTICE, Novas tecnologias da informação, comunicação e expressão. Sem o cidadão digitalmente incluído, todo projeto de desenvolvimento científico e tecnológico baseado no acesso à Sociedade da Informação tende à falência e à promoção de mais exclusão social. Assim sendo, a promoção da inclusão digital de todos deve ser encarada como um desafio do Estado, como um direito para o exercício pleno da cidadania (BRAGA e LACERDA SANTOS, 2012, p. 12). Ferreira e Lacerda Santos (2014, p. 53) apontam que não existem fórmulas pedagógicas miraculosas para que as escolas possam integrar adequadamente as TDICE, Tecnologias digitais da informação, comunicação e expressão, em sua dinâmica de funcionamento. Mas, qualquer que seja a direção da discussão, é senso comum que o professor é ator protagonista desse processo, sob cuja atuação repousa, portanto, o pertencimento da escola à Sociedade Informacional e sua pertinência no que diz respeito à formação para a cidadania nesta nova sociedade.

\subsection{Formação de Professores para a Sociedade da Informação}

Com o passar do tempo o giz vem cedendo espaço ao computador para se adequar ao mundo globalizado que se conecta às novas tecnologias, sendo assim o professor precisa investir continuamente na construção e reconstrução de seus conhecimentos pedagógicos e tecnológicos, procurando dessa forma criar uma reflexão do impacto que essas inovações têm causado nas instituições de ensino, levando em consideração as condições de trabalho que lhe são oferecidas (SANTOS, 2003).

O contexto em que trabalha o magistério tornou-se complexo e diversificado. Hoje, a profissão já não é mais a mera transmissão de um conhecimento acadêmico ou a transformação do conhecimento comum do aluno em um conhecimento acadêmico. A função de ensinar dos docentes é um reconhecimento complexo de fazer aprender alguma coisa, o saber fazer, saber como fazer e saber por que se faz. Não é tarefa fácil para os professores, por isso é preciso investir na sua formação e no seu conhecimento, bem como na produção deste (ROLDÃO, 2007). 
A formação assume um papel que transcende o ensino que pretende apenas uma atualização científica, pedagógica e didática e se transforma na possibilidade de criar espaços de participação, reflexão e formação para que as pessoas aprendam e se adaptem para poder conviver com a mudança e a incerteza. Enfatizam-se mais a aprendizagem das pessoas e a forma de torná-la possível do que o ensino e o fato de alguém esclarecer e servir de formador.

As novas exigências sociais têm direcionado e encaminhado a formação e a ação docente para novos rumos, ou seja, o docente deve ser um professor diferente, capaz de se ajustar às novas exigências da sociedade, do conhecimento, dos meios de comunicação e informação, dos alunos e dos diversos universos culturais. Carvalho Nunes (2012) salienta que, em razão das demandas postas pela atual sociedade da informação e do conhecimento, a educação é conclamada a se modificar, seja na tentativa de humanizar processos de tecnologização das relações sociais, seja na busca de contribuir com a formação de cidadãos preparados para atuarem em face da flexibilidade e da mutabilidade do mundo contemporâneo.

É fundamental que a instituição formativa conceba e situe a prática de ensino como elemento articulador da formação do professor e garanta o envolvimento das diferentes disciplinas do curso de formação, para que se possa contribuir com o projeto, oferecendo subsídios e participando concretamente da sua orientação, acompanhamento, execução e avaliação. Sacristán (1995) defende a necessidade de desenvolver a profissionalidade dos professores no contexto de uma maior qualidade no ensino; para atingir este objetivo, é preciso fazer um esforço de compreensão das "práticas" nas suas diversas configurações.

Transformar a educação e produzir uma nova profissionalização docente é tarefa social, coletiva, que envolve o Estado, os docentes e toda a sociedade. Não obstante, as TICs não vêm substituir nem tirar a importância da Pedagogia, dos docentes ou de sua formação; pelo contrário, vêm reforçar sua necessidade. O novo perfil e o novo papel docente que o sistema escolar requer devem articular antigas e novas necessidades de aprendizagem docente, entre as quais a própria administração das TICs para fins de ensino e aprendizagem (OLIVEIRA, NUNES e DOS SANTOS, 2012, p. 100). 
O projeto de formação deverá assegurar a adoção de propostas avaliativas permanentes que permitam analisar os avanços do processo e os redirecionamentos que se fizerem necessários. Vale reiterar que a qualidade da educação e da formação de professores está diretamente relacionada ao estabelecimento e à implementação de políticas educacionais que valorizem o magistério, contemplando igualmente a formação inicial e continuada de professores juntamente com sua valorização. Estas são as condições essenciais para se proporcionar um ensino de qualidade, acesso e permanência dos alunos na escola, tornando-a, de fato, democrática.

O saber vem se descentrando em relação ao que foi seu eixo durante os últimos séculos: o livro. Estamos vivendo em plena era da comunicação e da informação, graças ao fenômeno da globalização e, mais especificamente, ao advento da internet e da ciência da computação. O contexto do mundo globalizado é caracterizado pela praticidade e justamente por uma visão de totalidade em todo e qualquer empreendimento que se queira realizar.

Martin-Barbero (2014, p. 83) elucida que a aprendizagem ao longo da vida, exigida pelos novos modos de relação entre conhecimento e produção social, as novas modalidades de trabalho e a reconfiguração dos ofícios e profissões, não significa o desaparecimento do espaço-tempo escolar. Mas as condições de existência desse tempo, e de sua particular situação na vida, se veem transformadas radicalmente não só porque agora a escola tem que conviver com saberes-sem-lugar-próprio, mas porque inclusive os saberes que nela são ensinados encontram-se atravessados por saberes do ambiente tecnocomunicativo regidos por outras modalidades e ritmos de aprendizagem que os distanciam do modelo de comunicação escolar.

Estamos caminhando para uma nova fase de convergência e integração das mídias: tudo começa a integrar-se com tudo, a falar com tudo e com todos. Tudo pode ser divulgado em alguma mídia. Todos podem ser produtores e consumidores de informação. A digitalização traz a multiplicação de possibilidades de escolha, de interação. A mobilidade e a virtualização nos libertam dos espaços e dos tempos rígidos, previsíveis, determinados. O mundo físico se reproduz em plataformas digitais, e todos os serviços começam a poder ser realizados, física ou virtualmente (MORAN, 2013, p. 14). 
Gomez (2010, p. 100) elucida que a mudança de postura dos professores será uma decorrência do acesso, uso e recriação da rede. Não se deve colocar o professor como protagonista das mudanças no viés daquele que não foi formado para tal situação, mas sim como aquele que aprende ou pode aprender permanentemente e por isso ensina.

Os estudantes podem participar de conferências eletrônicas desterritorializadas nas quais intervêm os melhores pesquisadores de sua disciplina. A partir daí, a principal função do professor não pode mais ser apenas a difusão dos conhecimentos, que agora é feita também por outros meios. Sua competência deve deslocar-se no sentido de incentivar a aprendizagem e o pensamento. $\mathrm{O}$ professor torna-se um animador da inteligência coletiva dos grupos que estão a seu encargo. Sua atividade será centrada no acompanhamento e na gestão das aprendizagens: o incitamento à troca dos saberes, a mediação relacional e simbólica, a pilotagem personalizada dos percursos de aprendizagem (LÉVY, 2010, p. 173).

Em relação à educação, Kenski (2012, p. 47) argumenta que as redes de comunicação trazem novas e diferenciadas possibilidades para que as pessoas possam se relacionar com os conhecimentos e aprender. Já não se trata apenas de um novo recurso a ser incorporado à sala de aula, mas de uma verdadeira transformação, que transcende até mesmo os espaços físicos em que ocorre a educação. A dinâmica e a infinita capacidade de estruturação das redes colocam todos os participantes de um momento educacional em conexão, aprendendo juntos, discutindo em igualdade de condições, e isso é revolucionário. A autora afirma que

As mudanças contemporâneas advindas do uso das redes transformaram as relações com o saber. As pessoas precisam atualizar seus conhecimentos e competências periodicamente, para que possam manter qualidade em seu desempenho profissional (KENSKI, 2012, p. 47).

Precisamos formar professores que vislumbrem além da ferramenta ou tecnologia que estarão utilizando. Necessitamos de docentes que possam analisar de forma crítica a informação que absorvem, refletindo e gerando conhecimento. Belloni (2005, p. 24) adverte que é fundamental reconhecer a importância das TIC e a urgência de criar conhecimentos e mecanismos que possibilitem sua integração à educação; é também preciso evitar o "deslumbramento" que tende a levar ao uso mais ou menos 
indiscriminado da tecnologia por si e em si, ou seja, mais por suas virtualidades técnicas do que por suas virtudes pedagógicas.

Kenski (2012, p. 21) pontua que a evolução tecnológica não se restringe apenas aos novos usos de determinados equipamentos e produtos. Ela altera comportamentos. A ampliação e a banalização do uso de determinada tecnologia impõem-se à cultura existente e transformam não apenas o comportamento individual, mas o de todo o grupo social. Ela ressalta que a grande revolução do ensino não se dá apenas pelo uso mais intensivo do computador e da internet em sala de aula ou em atividades a distância. É preciso que se organizem novas experiências pedagógicas em que as TICs possam ser usadas em processos cooperativos de aprendizagem, em que se valorizem o diálogo e a participação permanentes de todos os envolvidos no processo (KENSKI, 2012, p. 88). A autora esclarece que

Para que as TICs possam trazer alterações no processo educativo, no entanto, elas precisam ser compreendidas e incorporadas pedagogicamente. Isso significa que é preciso respeitar as especificidades do ensino e da própria tecnologia para poder garantir que o seu uso, realmente, faça diferença. Não basta usar a televisão ou o computador, é preciso saber usar de forma pedagogicamente correta a tecnologia escolhida (KENSKI, 2012, p. 46).

Torna-se muito importante o planejamento para a utilização das TDICE em sala de aula. Para que uma tecnologia possa agregar valor ao processo de ensinoaprendizagem se torna necessário um bom plano pedagógico do seu uso.

Atualmente, com a grande difusão e o fácil acesso à tecnologia e com o aumento crescente no número de usuários, os problemas em relação ao uso das novas ferramentas tecnológicas também começam a preocupar. Moran (2013, p. 54) relata que em muitas ocasiões o aluno se torna dependente ou até mesmo "escravo" de tais ferramentas tecnológicas, como a internet por exemplo, e em inúmeras vezes deixa até mesmo de cumprir suas obrigações devido aos atrativos recursos que essas ferramentas oferecem. Há facilidade de dispersão. Muitos alunos se perdem no emaranhado de possibilidades de navegação. Não procuram o que está combinado, deixando-se arrastar para áreas de interesse pessoal. Moran (2013, p. 57) alerta que 
Ensinar utilizando as tecnologias traz uma série de desafios cada vez mais complexos. De um lado, temos mais informação, variedade de materiais, canais, aplicativos, recursos. Essa variedade exige capacidade de escolha, avaliação e concentração. As TDICE, principalmente as redes sociais, podem nos ajudar ou nos atrapalhar. É muito fácil nos distrair, passear pelas telas, pelas imagens, sem que haja tempo para focar o essencial, para ler com atenção, para compreender em profundidade. $\mathrm{O}$ maior perigo de todos é navegar muito e conhecer pouco de verdade; distrair-nos muito e concentrarnos pouco; saber um pouco de tudo e não compreender os fenômenos de verdade.

Em relação à utilização do computador em casa, também há o problema de a criança ou jovem deixar de fazer os deveres e trabalhos para ficar navegando na internet atrás de bate-papos, jogos e outras coisas do gênero. É perceptível que o computador leva o estudante à desconcentração e o estimula a omitir seus deveres, o que consequentemente prejudicará seu estudo e seu desempenho escolar. Necessita-se de uma forte dose de atenção do professor, pois diante de tantas possibilidades de busca, a própria navegação se torna mais sedutora do que o necessário trabalho de interpretação. Segundo Moran (2013, p. 57),

Diante de tantas possibilidades de busca, a própria navegação torna-se
mais sedutora do que o necessário trabalho de interpretação. Alunos e
professores tendem a dispersar-se diante de tantas conexôes possíveis,
de endereços dentro de outros endereços, de imagens, textos e
mensagens, que se sucedem e se intercomunicam ininterruptamente
nas múltiplas telas dos diversos recursos móveis que temos à
disposição.

O perigo está no encantamento que as tecnologias mais novas exercem em muitos (jovens e adultos), no uso mais para entretenimento do que pedagógico e na falta de planejamento das atividades didáticas. Sem planejamento adequado, as tecnologias dispersam, distraem e podem prejudicar os resultados esperados. Sem a mediação efetiva do professor, o uso das tecnologias na escola favorece a diversão e o entretenimento, e não o conhecimento (MORAN, 2013, p. 59).

Outro ponto preocupante é a prática da cópia ou plágio de conteúdos, atividades, textos encontrados na internet para trabalhos escolares. Muitos alunos utilizam este tipo de recurso, e isso mostra que de certo modo o computador e a internet facilitam as coisas de uma maneira prejudicial ao aluno, fazendo com que ele não se esforce para conseguir realizar sua obrigação. Também há casos em que o trabalho 
escolar é feito pelo aluno, porém possui informações equivocadas que foram retiradas de fontes errôneas na internet. Mais uma vez o acompanhamento e a instrução do professor se fazem muito importantes. Silva (2008, p. 358) relatando o problemas com os plágios na universidade elucida que,

[...] na busca por caminhos mais fáceis e mais velozes, e tendo como aliada a natureza aparentemente pública do conteúdo on-line, além da disponibilidade/acessibilidade dos hipertextos digitais, na universidade essa prática tem-se dado de forma mais abrangente e acentuada, haja vista a velocidade na transmissão das informações - cruas ou refinadas - e a grande quantidade de textos/obras à disposição do leitor na internet.

Um obstáculo grandioso para a difusão e o uso das tecnologias é o acesso. Nem todos os alunos têm computador; além disso, muitas vezes o acesso à internet é restringido pela velocidade ou pela disponibilidade de tempo (em casa, no trabalho ou na lan house). Não basta haver distribuição de equipamentos e acesso à internet para os professores. É preciso que essas ações de democratização do acesso estejam integradas a outros programas de atualização e formação dos professores.

Uma grande dificuldade do docente é a reconstrução da sua prática pedagógica, principalmente quando os pressupostos educacionais que orientam o uso das TDICE são diferentes da concepção de ensino e de aprendizagem do partilhado na escola. Além disso, alguns docentes acreditam que, utilizando as tecnologias nas suas aulas, eles podem perder o controle da situação, já que os estudantes podem ter acesso prévio ao material a ser estudado.

Outro problema gerado é a intensificação do trabalho docente. O professor passa a ficar on-line no mundo web e tem seu trabalho prolongado ao longo do dia. Segundo Oliveira (2010, p. 87) hoje o ritmo de trabalho do professor é maior que o de algum tempo atrás, quando ainda não adotavam as tecnologias da informação em sua prática cotidiana.É possível perceber que o trabalho docente está mais comprimido na jornada normal de um dia. Eles têm que desenvolver mais atividades, preparar mais aulas, orientar mais alunos, ler dezenas de e-mail's, etc. em um intervalo de tempo que não aumentou nos últimos 30 ou 40 anos. O autor elucida que 
Em um mesmo espaço de tempo, a tarefa de buscar informações e conhecimentos que possam ser revertidos nos alunos, aumentou consideravelmente. Até bem pouco tempo atrás, tinham apenas livros para procurarem conteúdos para suas aulas e atividades docentes. Agora, principalmente com a internet, possuem à sua disposição uma infinidade de possibilidades de pesquisa. Por isso, os professores sentem seu trabalho comprimido no mesmo tempo de que dispunham antes do incremento das TIC (OLIVEIRA, 2010, p. 88).

Antes de utilizarem as tic's, eles preparavam aulas basicamente utilizando livros, artigos, revistas, etc. Atualmente, entretanto, as possibilidades de busca de informações expandiram-se tanto, especialmente com a internet, que se um professor fosse tentar esgotar todos os sites sobre um determinado assunto, ele levaria dias, ou até mesmo semanas, para preparar uma única aula. Hoje, segundo Oliveira (2010, p. 89), o trabalho do professor não se limitaria mais apenas a instrução das novas gerações, mas estaria envolvido em um conjunto de atividades que demandaria um alto grau de polivalência. Ao professor da era da informática seriam cobradas desde competências relacionadas ao trabalho em equipe, flexibilidade, iniciativa e criatividade até o domínio de sua própria formação e gerência de suas emoções.

A intensificação do trabalho docente se daria, então, em grande parte, porque a relação dos professores com os alunos seria mais complexa e multidimensional. Ela comportaria tensões e dilemas importantes e seria determinada por fatores ambientais: pobreza, violência, etc (OLIVEIRA, 2010, p. 89)

Oliveira (2010, p. 93) salienta que é preciso se levar em consideração que o professor, um profissional da educação que sofre todos os males advindos da desvalorização da educação brasileira, passa por grandes dificuldades em compreender as tecnologias da informação como inovações implicativas no seu processo de trabalho. $\mathrm{O}$ autor esclarece que as pesquisas sobre essa temática ainda são muito incipientes, os cursos de licenciatura em geral não discutem as TIC e as autoridades educacionais não conferem a elas a devida relevância. Portanto, conhecer as tecnologias da informação e suas implicações para o trabalho docente são competências fundamentais para 0 professor do século XXI. Significa obter maior controle sobre o seu processo de trabalho e garantir maior posição no embate entre capital e trabalho. 
Santos (2003) salienta que estamos em um momento especial na história da Educação, num ínterim entre o giz e o computador. Essa transição gera expectativas, impõe novas posturas para se organizar e gerenciar uma escola, uma sala de aula, pessoas. É importante ressituar as funções do professor, de seu trabalho no tempo, aproveitando suas experiências, frutos de uma história, e que indicam a necessidade de se adotar novas posturas para que as mudanças emergentes do mundo sejam acompanhadas. A adoção de novas posturas pertence a todos que estão comprometidos com a ação educativa.

Aos educadores se faz de muita importância a apropriação das TDICE, para que se possa estabelecer a inserção dos alunos na sociedade da informação, podendo passar aos alunos todos os recursos que as tecnologias educacionais nos oferecem. $\mathrm{O}$ professor tem uma grande importância nessa disseminação do saber, implicando toda uma preparação que começa em sua formação, capacitando-o a estar apto a utilizar, ter noções computacionais e explorar as novas ferramentas tecnológicas, para que este possa criar aulas as mais interativas e envolventes possíveis, tornando os alunos seres ativos na sua constituição do saber. Para Freitas (2010, p. 340),

Os professores precisam conhecer os gêneros discursivos e linguagens digitais que são usados pelos alunos, para integrá-los, de forma criativa e construtiva, ao cotidiano escolar. Quando digo integrar é porque o que se quer não é o abandono das práticas já existentes, que são produtivas e necessárias, mas que a elas se acrescente o novo.

O papel dos profissionais que atuam na educação é mostrar ao aluno para que serve o conhecimento e apontar formas de alcançá-lo. Ele precisa enxergar-se, apenas, como uma parte do processo de aprendizado. Teremos professores interagindo uns com as aulas dos outros e contribuindo com um conhecimento específico em determinada área, estabelecendo assim uma rede de criação de conhecimento. O conceito de curso, de aula, também muda. Hoje, ainda entendemos por aula um espaço e um tempo determinados. Mas, esse tempo e esse espaço, cada vez mais, serão flexíveis.

Para Masetto (2013, p. 142), o professor assume uma nova atitude. Embora, vez por outra, ainda desempenhe o papel do especialista que possui conhecimentos e/ou experiências a comunicar, o mais das vezes ele vai atuar como orientador das atividades 
do aluno, consultor, facilitador, planejador e dinamizador de situações de aprendizagem, trabalhando em equipe com o aluno e buscando os mesmos objetivos.

As instituições formadoras de nível superior precisam, além de inclusão de disciplinas e conteúdos sobre o uso das TICs em seus currículos das licenciaturas, incluindo a Pedagogia, oferecer instalações físicas, pessoas e materiais adequados a uma formação científica e tecnológica do futuro professor. Há necessidade urgente de investimento na formação de professores para utilizar o potencial das tecnologias em favor de sua formação e do processo de ensino-aprendizagem (NUNES, 2012, p. 45). O autor cita que

\begin{abstract}
A formação docente precisa ser compreendida como um continuum, envolvendo três etapas: a inicial, a indução e a continuada. Os professores necessitam da formação continuada para estarem em dia com as mudanças em curso na educação, assim como necessitam de acompanhamento no seu início no magistério em escola privada ou pública ou quando precisam exercer a docência em um sistema de ensino novo para eles (NUNES, 2012, p. 46).
\end{abstract}

O professor continuará lecionando, e enriquecerá esse processo com as possibilidades que as tecnologias interativas proporcionam, para receber e responder mensagens dos alunos, criar lista de discussão e alimentar continuamente os debates e pesquisas com textos, páginas da internet, até mesmo fora do horário específico da aula. Ressalta-se que

Saber usar os dispositivos de comunicação, mas também refletir como eles afetam e contribuem para a vida das pessoas; saber como a informação na internet, a partir da produção e das observações pessoais, pode contribuir para a experiência social; saber como a tecnologia permite esse registro e como sua convergência com as pessoas permite achar questões em comum para uma melhor organização e realização social; por fim saber como uma pedagogia dialógica e crítica pode ir além do simples âmbito da informação e dos dados, promovendo a liberdade de expressão e a autonomia para aprender (GOMEZ, 2010, p. 134).

A educação pode modificar-se significativamente com a introdução das tecnologias. As paredes das escolas e dos ambientes educacionais se abrem, as pessoas se intercomunicam, trocam informações, dados, pesquisas. A educação escolar precisa compreender e incorporar mais as novas linguagens, desvendar os seus códigos, 
dominar as possibilidades de expressão e as possíveis manipulações. É importante educar para usos democráticos, mais progressistas e participativos das tecnologias, que facilitem a evolução dos indivíduos (MORAN, 2013, p. 53).

A educação, nesta sociedade que respira a conexão e interatividade, necessita acompanhar as mudanças ocorridas e possibilitar o preparo do aluno para sua inserção no meio social. O uso das tecnologias na escola precisa ser integrado ao projeto pedagógico da instituição considerando as histórias de vida e características de professores, alunos e das próprias turmas (NUNES, SILVEIRA e XAVIER, 2012). A educação tem a obrigação de contemplar tais temas na escola, seja na formação de professores ou como conteúdo para alfabetização de alunos. Privar tais atores do contato e conhecimento sobre os recursos tecnológicos utilizados no dia a dia pelos alunos e sociedade em geral se consolida em uma omissão da escola, que tem o dever de disciplinar e apontar maneiras de desfrutar das tecnologias para criação do conhecimento.

\subsection{Inclusão Digital de Professores}

Para Santos (2007, p. 19 apud LACERDA SANTOS e FIRMINO, 2014, p. 37) a inclusão digital pode ser considerada como um conjunto de ações permeadas pelas TDICE que possibilitam ao indivíduo que a possui ascender social e economicamente, visto que a posse, a produção e a disseminação da informação podem ser consideradas, à luz desta nova sociedade, as atividades econômicas e sociais primárias. Caracteriza-se por uma mudança comportamental e atitudinal, que ocorre no momento em que o sujeito atinge um nível de conhecimento e habilidades que lhe permita utilizar, interagir e processar dados e informações utilizando-se de recursos tecnológicos aliados ao desenvolvimento de competências na área motora, cognitiva e afetiva. Para Gomez (2010, p. 12),

A inclusão digital vai além do ler e do escrever. Trata-se de entender, significar, de pensar e dar sentido ao mundo a partir do nosso contexto cultural. É a habilidade e a possibilidade para entender e usar informação em múltiplos formatos, é a visualização, a escuta e a colaboração com os outros, é achar e produzir textos e utilizá-los para a própria vida. 
A democratização do acesso à informação por meio do acesso à internet é um fator fortemente relacionado à inclusão social. Neste sentido, pode-se afirmar que a inclusão social é diferenciada no contexto da sociedade da informação. Demo (2002) elucida que ser excluído é sobremaneira estar à margem do conhecimento. Nesta perspectiva, o analfabeto não é somente aquele que não sabe ler, mas é o sujeito que não consegue trabalhar elementarmente o conhecimento para reconstruí-lo. Desta forma, se o computador insere os sujeitos sociais nos diversos fluxos da sociedade em que vivem, o não desenvolvimento de habilidades para este uso pode se constituir em elemento de exclusão (FERREIRA, 2009, p. 34).

O conceito de inclusão digital implícito em políticas públicas de inclusão digital, atualmente, não leva em consideração a assimilação de competências e habilidades necessárias para que os indivíduos obtenham sucesso em quaisquer ações mediadas pelas TDICE. Seja em ações voltadas para o relacionamento, para a formação profissional, para o exercício pleno da cidadania, ou em ações voltadas para sua formação acadêmica, inicial ou continuada. Sua concepção está baseada em esforços do Governo Federal em universalizar a penetração das TDICE em todas as esferas sociais. Desta forma, acredita-se que a posse de equipamentos e sistemas aliados a programas de ampliação da oferta de internet é suficiente para a inclusão digital destes indivíduos. Não verificam, entretanto, a qualidade do acesso (LACERDA SANTOS e FIRMINO, 2014, p. 45). Os autores enaltecem que

[...] essas políticas públicas de inclusão digital têm implícitas em si o conceito de um indivíduo cuja inclusão digital já está presente em níveis significativos ou que ela será construída durante seu projeto de implantação e execução, até a sua conclusão. Não conseguem ou não querem se apropriar do conceito de que há, de fato, a necessidade de se construir novas linguagens, atitudes e estratégias para que o uso destas TDICE seja significativo para o sucesso nestas ações (LACERDA SANTOS e FIRMINO, 2014, p. 46).

Ferreira (2009, p. 35) expressa que os problemas oriundos da implantação de políticas públicas para a inclusão digital são decorrentes da preocupação maior com a inserção do hardware e software. O que gera pouca ênfase aos aspectos sociais contextuais desses programas, que deveriam também ser enfatizados para que as tecnologias pudessem fazer a diferença. $\mathrm{O}$ autor ainda realça que 
[...] o acesso ao computador e à internet é decisivo para o avanço da inclusão social na sociedade da informação. Contudo, os modelos baseados em conectividade e equipamentos são insuficientes (FERREIRA, 2009, p. 41).

Lacerda Santos e Firmino (2014, p. 46) ressaltam que, quando falamos em inclusão digital no campo educacional, ainda existe um agravante: sendo os educadores os responsáveis pela formação destes novos cidadãos, ativos, críticos e transformadores, está implícita, na função social da escola, a responsabilidade de atuar, efetiva e significativamente, na inclusão digital de seus alunos. Os autores esclarecem que grande parte destas TDICE será inserida no ambiente escolar pelos alunos. De forma não sistematizada, os alunos estarão trazendo para o microcosmo que é a escola, as demandas e os anseios da sociedade, cujos aspectos socioeconômicos, políticos e de relações sociais já foram transformados pelas TDICE. A sociedade está cobrando dos nossos alunos novas formas de se informarem, comunicarem e expressarem, nas mais diversas relações sociais. E, infelizmente, estas habilidades não estão sendo desenvolvidas por meio do ensino tradicional (LACERDA SANTOS e FIRMINO, 2014, p. 47).

A sociedade da informação é caracterizada pela abundância informacional; a exigência no desenvolvimento de habilidades específicas para lidar com a informação; comunicação; predomínio da competência informacional; desenvolvimento e utilização de novas tecnologias educacionais e de recursos para recuperação da informação. Essas características impõem alguns desafios a serem enfrentados, tais como: exigência de novas posturas com relação à forma de ensinar e aprender; educação permanente; domínio sobre as novas tecnologias e a formação de pessoas.

O grande desafio dos profissionais da educação e da informação está na capacidade de organizar, selecionar e filtrar informações relevantes a cada contexto; em meio à quantidade imensa de dados disponíveis, os professores tornam-se responsáveis pela promoção da mediação entre a sociedade da informação e os seus alunos (PASSOS, SOUZA e SANTOS, 2007). Lacerda Santos, Ferreira e Castro (2014, p. 53) observam que 
A inclusão digital de professores, apesar de vir surgindo gradativamente como necessidade pedagógica há várias décadas, é ainda uma abordagem extremamente inovadora na sala de aula e no trabalho docente, constituindo um importante desafio para formadores de formadores, para os professores em ação e para os responsáveis por políticas públicas para o setor.

A inclusão digital de professores para promover a inclusão social não pode ter como base somente o suprimento de equipamentos e conectividade. A inclusão digital deve envolver uma gama de recursos, cuja finalidade seja ampliar os poderes social, econômico e político destes educadores e, consequentemente, de seus alunos e de toda a sociedade (FERREIRA, 2009, p.40).

Para Almeida (2004), a inclusão digital de professores consiste na formação para a incorporação do uso da informática nos processos educativos, tendo como base o domínio da tecnologia, a atuação docente usando tais tecnologias e a articulação disso com teorias educacionais relacionadas a essa prática. Com o avanço da Sociedade Informacional surgem desafios no sentido de ampliar a capacidade educativa e cultural de se usar as mídias digitais fundadas no computador.

É necessário, pois, que se aprenda a buscar informações e construir habilidades individuais e coletivas para que se possa impulsionar a elaboração de novos conhecimentos no âmbito escolar. Sob essa perspectiva de emergência da construção de saberes para a integração do cidadão à sociedade informacional é que surgem termos como inclusão digital, alfabetização digital e letramento digital. A inclusão digital de professores engloba a alfabetização digital e o letramento digital (LACERDA SANTOS, FERREIRA e CASTRO, 2014, p. 56).

Para Lacerda Santos, Ferreira e Castro (2014, p. 56), há diferenças entre ser alfabetizado e letrado. O letramento digital é, pois, a situação do sujeito que, conhecedor de técnicas e TDICE, é capaz de usá-las, para agir no seu meio social, fazer inferências, intervir de forma a transformar esse meio. Alfabetização e letramento possuem significados muito próximos, mas não são considerados semelhantes.

Buzato (2003 apud SILVA et al., 2005, p. 33), esclarece que as pessoas alfabetizadas não são necessariamente "letradas", pois apesar de saberem ler e escrever 
muitas pessoas não conseguem construir uma argumentação, interpretar um gráfico, encontrar um livro em um catálogo, etc. Para o autor, o letramento é a competência que vai além da aprendizagem de um código linguístico, que possibilita a construção de sentidos e consequentemente a construção de conhecimento, com base no que foi aprendido. Logo, letramento digital seria a habilidade para construir sentido, capacidade para localizar, filtrar e avaliar criticamente a informação eletrônica. Silva et al. (2005, p. 33) descrevem que

O letramento é a competência em compreender, assimilar, reelaborar e chegar a um conhecimento que permita uma ação consciente, o que encontra correspondente no letramento digital: saber utilizar as TICs, saber acessar informações por meio delas, compreendê-las, utilizá-las e com isso mudar o estoque cognitivo e a consciência crítica e agir de forma positiva na vida pessoal e coletiva.

Freitas (2010, p. 339) entende o letramento digital como o conjunto de competências necessárias para que um indivíduo entenda e use a informação de maneira crítica e estratégica, em formatos múltiplos, vinda de variadas fontes e apresentada por meio do computador-internet, sendo capaz de atingir seus objetivos, muitas vezes compartilhados social e culturalmente.

A razão pela qual temos necessariamente que pensar em letramentos digitais quando refletimos sobre a inclusão digital não é tão trivial quanto pode parecer à primeira vista. Não se trata apenas de reconhecer que o acesso às TIC pressupõe a capacidade de receber e produzir informação por meio da escrita utilizada em dispositivos digitais, algo que o senso comum sobre a inclusão digital costuma denominar "alfabetização digital". Trata-se de ampliar qualitativamente o conceito de inclusão, como se fez e se tem feito em relação à escrita em sentido amplo, contrastando a ideia mais restrita de alfabetização com a noção mais ampla e socialmente significativa de letramento (BUZATO, 2007, p. 142). O autor

[...] propõe uma visão dos letramentos digitais como redes complexas de letramentos (práticas sociais) que se apóiam, se entrelaçam, se contestam e se modificam mútua e continuamente por meio, em virtude e/ou por influência das TIC (2007, p. 168).

Gomes, Silva e Nunes (2013, p.76) expressam que o letramento digital do professor deve torná-lo capaz de, na sua ação docente, desenvolver atividades como, por 
exemplo, a leitura de vídeo musical, que envolve o processamento de imagens, música e narrativa, dele exigindo múltiplas competências e habilidades no manuseio de variadas formas estéticas. Segundo Passos, Souza e Santos (2007), o letramento digital será efetivo quando as pessoas alfabetizadas em informação forem capazes de saber:

- como se organiza o conhecimento;

- como encontrar e interpretar a informação;

- como usar a informação para construir o seu próprio aprendizado;

- como construir o seu próprio conhecimento.

O desenvolvimento de uma cultura informacional, nesta sociedade, evidencia a atuação de dois profissionais, os educadores e os profissionais da informação, pelo fato de estarem diretamente ligados com a formação de indivíduos, nas questões de acesso, seleção e interpretação da gama de informações disponíveis. Esses profissionais são estimulados a alterar suas formas de atuação. Moran (2013, p. 26), expressa a importância do perfil do professor para a sociedade da informação, e destaca que ele precisa assumir o seu papel de pesquisador em serviço, tornando-se um orientador/ mediador intelectual, ou seja, aquele que informa, ajuda na escolha de informações mais importantes, trabalhando com elas e fazendo com que se tornem significativas aos seus alunos, possibilitando a eles maior compreensão, avaliação e condições de reelaborar e adaptar esses novos elementos ao seu contexto pessoal. Gomes, Silva e Nunes (2013, p. 79) enaltecem que

[...] se nossas crianças, jovens e adultos necessitam estar incluídos digitalmente, os docentes também precisam estar formados para utilizar adequadamente as TICs em prol da alfabetização e do letramento desse público, base para as demais aprendizagens necessárias ao seu pleno desenvolvimento como cidadãos.

Para Lacerda Santos, Ferreira e Castro (2014), a inclusão digital de professores deve ser capaz de inserir de forma definitiva o professor na Sociedade Informacional. Contudo, essa inserção só pode ser considerada efetiva se o professor for capaz de, além de fazer uso do que aprendeu para suas necessidades pessoais, empregar esse saber para todas as articulações sociais, o que inclui, obviamente, o seu trabalho com os educandos. São necessárias, desse modo, modificações nas estratégias de formação para a inclusão digital, para que possam se dar abalizadas por um conteúdo teórico 
relacionado às habilidades linguísticas de seu público-alvo, voltadas para o uso dos conhecimentos para intervenção social (inclua-se o trabalho pedagógico com alunos) e vinculadas com as instituições, nas quais atuam os sujeitos em formação.

Moran (2013, p. 49) lembra que há inúmeros aplicativos, programas e recursos que podem ser utilizados de forma criativa e inovadora. $\mathrm{O}$ autor afirma que o papel do educador é fundamental se agrega valor ao que o aluno sozinho consegue fazer com a tecnologia; e o aluno aprende mais se, na interlocução com o educador e seus colegas, consegue avançar muito mais do que se aprendesse sozinho. As tecnologias estão cada vez mais próximas do professor e do aluno, em qualquer momento; são mais ricas, complexas, atraentes. Exigem um profissional mais interessante que elas, mais competente que elas. Caso contrário, os alunos sempre encontrarão uma forma de darlhe as costas e de considerar o papel desse professor irrelevante, o que é muito triste e, infelizmente, costuma acontecer com frequência.

A popularização da internet e da informática exige um novo dinamismo do ensino. Necessita-se responder à demanda e atender a um público culturalmente digital. A inclusão digital permite acesso maior às informações aos alunos e professores. A possibilidade de pesquisar, ler e conhecer sobre os mais variados assuntos navegando na internet confere ao aluno um novo perfil de estudante, que exige também um novo perfil de professor. O professor é o ponto-chave em todo esse processo perante seu papel de mediação e problematização do conhecimento, um professor que não se resume a ensinar, mas que também aprende com o aluno. A instrumentalização quanto ao uso da tecnologia não é o suficiente para que os professores sejam realmente incluídos digitalmente, então torna-se importante que estes professores compreendam a essência e o conceito da tecnologia na educação e saibam utilizá-la para a realidade de sua prática pedagógica.

\subsection{O Curso de Pedagogia}

Ao pesquisar sobre a formação do curso de Pedagogia, identificaram-se os diferentes momentos históricos de sua constituição, as alterações na organização curricular e as influências sofridas em função do contexto sociopolítico do país no perfil 
profissional do pedagogo. Essa investigação permitiu, também, distinguir, de acordo com o contexto histórico, com quais funções o profissional da Pedagogia se relacionava.

A abordagem deste tema refere-se a uma grande discussão sobre o processo de formação de pedagogos e sobre a utilização das novas tecnologias durante sua formação inicial. O presente texto apresenta os aspectos relacionados com a formação do pedagogo no Brasil a partir da perspectiva teórica de autores como Libâneo (2010), Pimenta (2011), Saviani (2007, 2012), dentre outros. Será apresentada, a seguir, a conceituação, um breve histórico sobre o curso de Pedagogia no Brasil e sobre as mudanças na formação dos pedagogos nas últimas décadas, tendo em vista a importância do perfil deste profissional na sociedade atual.

Ao longo da história da chamada civilização ocidental, a Pedagogia foi se firmando como correlata da educação, entendida como o modo de apreender ou de instituir o processo educativo. Efetivamente, a educação aparece como uma realidade irredutível nas sociedades humanas. Sua origem se confunde com as origens do próprio homem. Na medida em que o homem se empenha em compreendê-la e busca intervir nela de maneira intencional, vai se constituindo um saber específico que, desde a paideia grega, passando por Roma e pela Idade Média chega aos tempos modernos fortemente associada ao termo pedagogia (SAVIANI, 2007, p. 100).

As conceituações para o termo pedagogia multiplicam-se, o pedagógico desdobra-se em múltiplos enfoques e a esperada unificação das perspectivas se desfaz. Outros negam-lhe caráter científico, considerando-a predominantemente como arte de educar. Para alguns ela é antes técnica do que arte, enquanto outros a assimilam à filosofia ou à história da educação, não deixando de haver, até mesmo, quem a considere como teologia da educação. Outra forma de entender a pedagogia é dada pelo termo "teoria", definindo-a como teoria da educação. Mas há, também, definições combinadas como ciência e arte de educar, ciência de caráter filosófico que estuda a educação apoiada em ciências auxiliares, e teoria e prática da educação (SAVIANI, 2012, p. 117).

Para Saviani (2012, p. 1), a Pedagogia desenvolveu-se em íntima relação com a prática educativa, constituindo-se como a teoria ou ciência dessa prática, sendo, em 
determinados contextos, identificada com o próprio modo intencional de realizar a educação. Ao longo de vários séculos, a Pedagogia construiu uma rica tradição teórica e científica sobre a prática educativa que deve continuar a ser desenvolvida, a despeito e até mesmo por causa das inúmeras negativas de que foi alvo na história do pensamento humano. $\mathrm{O}$ autor acredita que

[...] o conceito de pedagogia se reporta a uma teoria que se estrutura a partir e em função da prática educativa. Para ele, a pedagogia, como teoria da educação, busca equacionar, de alguma maneira, o problema da relação educador-educando, de modo geral, ou, no caso específico da escola, a relação professor-aluno, orientando o processo de ensino e aprendizagem (SAVIANI, 2007, p. 102).

Libâneo (2010, p. 29) aponta que a Pedagogia ocupa-se dos processos educativos, métodos, maneiras de ensinar, mas antes disso ela tem um significado bem mais amplo, bem mais globalizante. Ela é um campo de conhecimentos sobre a problemática educativa na sua totalidade e historicidade e, ao mesmo tempo, uma diretriz orientadora da ação educativa. O pedagógico refere-se a finalidades da ação educativa, implicando objetivos sociopolíticos a partir dos quais se estabelecem formas organizativas e metodológicas da ação educativa. O autor define a Pedagogia como

[...] o campo do conhecimento que se ocupa do estudo sistemático da educação, isto é, do ato educativo, da prática educativa concreta que se realiza na sociedade como um dos ingredientes básicos da configuração da atividade humana (LIBÂNEO, 2010, p. 30).

Seguindo nesta linha de pensamento, Libâneo (2010, p. 30) conceitua a educação como sendo o conjuto das ações, processos, influências, estruturas, que intervêm no desenvolvimento humano de indivíduos e grupos na sua relação ativa com o meio natural e social, num determinado contexto de relações entre grupos e classes sociais. É uma prática social que atua na configuração da existência humana individual e grupal, para realizar nos sujeitos humanos as características de "ser humano".

Libâneo (2010, p. 29) faz uma crítica da ideia simplista e reducionista de senso comum que muitos pedagogos têm de que Pedagogia é o modo como se ensina, o modo de ensinar a matéria, o uso de técnicas de ensino. O pedagógico somente em sentido metodológico e aos procedimentos. O autor defende que o pedagógico perpassa toda a sociedade, extrapolando o âmbito escolar formal, abrangendo esferas mais amplas da 
educação informal e não formal. Libâneo acredita que a Pedagogia é uma reflexão teórica a partir e sobre as práticas educativas. Para o autor,

Ela investiga os objetivos sociopolíticos e os meios organizativos e metodológicos de viabilizar os processos formativos em contextos socioculturais específicos. As práticas educativas ocorrem em muitos lugares e em muitas instâncias. Elas acontecem nas famílias, nos locais de trabalho, na cidade e na rua, nos meios de comunicação e, também, nas escolas. Não é possível mais afirmar que o trabalho pedagógico se reduz ao trabalho docente nas escolas (LIBÂNEO, 2010, p. 14).

Para Pimenta (2004, p. 8), o pedagogo é o profissional que estuda e que se insere na práxis da educação na sociedade. Portanto, vale dizer que esse estudo somente pode ser realizado como pesquisa das manifestações educativas, incluindo o ensino, que ocorrem nas sociedades. Para isso, são necessários os fundamentos de várias áreas do saber, inclusive daquelas que estudam o ensino. Sua inserção profissional será transformadora e propositiva se baseada nesses princípios. E ocorrerá nas instituições educativas existentes e a serem criadas, não apenas a escola.

A Pedagogia não é, certamente, a única área científica que tem a educação como objetivo de estudo. Também a Sociologia, a Psicologia, a Economia, a Linguística podem ocupar-se de problemas educativos, para além de seus próprios objetos de investigação e, nessa medida, os resultados de seus estudos são imprescindíveis para a compreensão do educativo. Entretanto, cada uma dessas ciências aborda o fenômeno educativo sob a perspectiva de seus próprios conceitos e métodos de investigação (LIBÂNEO, 2010, p. 37).

Pimenta (2004, p. 3) afirma que a Pedagogia é um campo de conhecimento específico da práxis educativa que ocorre na sociedade. Diferentemente dos demais que não têm a educação como objeto específico de análise, mas que a ela podem se voltar. O curso de Pedagogia se constitui no único curso de graduação no qual se realiza a análise crítica e contextualizada da educação e do ensino enquanto práxis social.

Libâneo (2010, p. 38) defende que a Pedagogia é um campo de estudos com identidade e problemáticas próprias. Seu campo compreende os elementos da ação 
educativa e sua contextualização, tais como o aluno como sujeito do processo de socialização e aprendizagem; os agentes de formação (inclusive a escola e o professor); as situações concretas em que se dão os processos formativos (entre eles o ensino); o saber como objeto de transmissão/assimilação; o contexto socioinstitucional das instituições (entre elas as escolas e salas de aula).

Desde a Grécia, delineou-se uma dupla referência para o conceito de pedagogia. De um lado, foi se desenvolvendo uma reflexão estreitamente ligada à filosofia, elaborada em função da finalidade ética que guia a atividade educativa. De outro lado, o sentido empírico e prático inerente à Paideia entendida como a formação da criança para a vida reforçou o aspecto metodológico presente já no sentido etimológico da pedagogia como meio, caminho: a condução da criança.

Saviani (2012, p. 3) esclarece que a problemática da Pedagogia remonta à Antiguidade, tendo se desenvolvido numa linha de continuidade, de certo modo ascensional, até chegar a ocupar, na atualidade, um lugar reconhecido no campo acadêmico-científico, e observa que nem sempre essa problemática foi tratada sob o nome de pedagogia. Ou seja: a trajetória histórica da problemática da Pedagogia não coincide necessariamente com a trajetória histórica do termo "pedagogia". O termo "pedagogia", é evidente, surgiu na Grécia. Da Grécia, tanto o termo quanto a problemática pedagógica transladaram-se para Roma.

Para o autor, é interessante observar que a passagem do grego para a língua latina deu origem a "paedagogatus", substantivo masculino da quarta declinação que significa educação, instrução; "paedagogus" e "paedagoga", com o sentido de pedagogo, preceptor, mestre, guia, aquele que conduz; e "paedagogium", substantivo neutro significando tanto a escola, mais especificamente destinada aos escravos, como as crianças que frequentam essa escola. Assim, a problemática pedagógica expressavase pelas palavras "paedagogatus" e "institutio", não se registrando o termo "paedagogia". No latim clássico a palavra "instututio" assumia o significado de educação ou formação, absorvendo o sentido grego de "paideia", posteriormente incorporado ao termo "pedagogia" (SAVIANI, 2012, p. 4). O autor cita que 
Foi a partir do século XIX que tendeu a se generalizar a utilização do termo "pedagogia" para designar a conexão entre a elaboração consciente da idéia da educação e o fazer consciente do processo educativo, o que ocorreu mais fortemente nas línguas germânicas e latinas do que nas línguas anglo-saxônicas. E esse fenômeno esteve fortemente associado ao problema da formação de professores (SAVIANI, 2012, p. 6).

Para Saviani (2012, p. 6), a questão da formação de professores irá exigir uma resposta institucional apenas no século XIX, quando, após a Revolução Francesa, se coloca o problema da instrução popular e de onde deriva o processo de criação de Escolas Normais, como instituições encarregadas de preparar professores.

A partir, porém, do século XIX, a necessidade de universalizar a instrução elementar conduziu à organização dos sistemas nacionais de ensino. Estes, concebidos como um conjunto amplo constituído por grande número de escolas organizadas segundo um mesmo padrão, viram-se diante do problema de formar professores, também em grande escala, para atuar nas referidas escolas. E o caminho encontrado para equacionar-se essa questão foi a criação de Escolas Normais, de nível médio, para formar professores primários, atribuindo-se ao nível superior a tarefa de formar os professores secundários (SAVIANI, 2012, p. 7).

Para o autor, neste contexto, configuram-se dois modelos de formação de professores:

a) modelo dos conteúdos culturais-cognitivos: para este modelo, a formação dos professores esgota-se na cultura geral e no domínio específico dos conteúdos da área de conhecimento correspondente à disciplina que o professor irá lecionar;

b) modelo pedagógico-didático: contrapondo-se ao anterior, este modelo considera que a formação propriamente dita dos professores só se completa com o efetivo preparo pedagógico-didático.

$\mathrm{Na}$ história da formação de professores, constatou-se que o primeiro modelo predominou nas universidades e demais instituições de ensino superior, que se encarregaram da formação dos professores secundários, ao passo que o segundo tendeu a prevalecer nas Escolas Normais, ou seja, na formação dos professores primários. 


\subsection{Breve Histórico da Formação dos Cursos de Pedagogia no Brasil}

A formação e constituição do curso de Pedagogia em nosso país passou e ainda passa por diversas discussões e conflitos em relação à sua finalidade e identidade. Desde sua idealização até os dias atuais se apresentaram algumas dicotomias no campo da formação do educador: professor versus especialista, bacharelado versus licenciatura, generalista versus especialista, técnico em educação versus professor.

Saviani (2012, p. 123) relata que uma marca na trajetória da Pedagogia foi seu caráter polêmico. Especialmente ao longo do século XX, o pensamento pedagógico foi atravessado por tendências contrapostas, a disputar a hegemonia do campo educativo. Pedagogia conservadora versus pedagogia progressista; pedagogia católica (espiritualista) versus pedagogia leiga (materialista); pedagogia autoritária versus pedagogia da autonomia; pedagogia repressiva versus pedagogia libertadora; pedagogia passiva versus pedagogia ativa; pedagogia da essência versus pedagogia da existência; pedagogia bancária versus pedagogia dialógica; pedagogia teórica versus pedagogia prática; pedagogias do ensino versus pedagogias da aprendizagem e, dominando todo o panorama e, em certo sentido, englobando as demais oposições, pedagogia tradicional versus pedagogia nova.

Para Libâneo (2010, p. 9), tem sido difícil obter consenso sobre questões cruciais: o que deve ser um curso de Pedagogia, o que define um trabalho como "pedagógico", em que consiste a formação pedagógica e o exercício profissional do pedagogo, se há lugar para especialização ou habilitações, qual a diferença entre pedagogo e professor, pedagogo e educador etc.

O curso de Pedagogia foi instituído pelo Decreto n. 1.190/39, que ao organizar a Faculdade Nacional de Filosofia, a estruturou em quatro seções: Filosofia, Ciências, Letras e Pedagogia acrescentando, ainda, a de Didática, considerada como "seção especial". Todos os cursos da Faculdade Nacional de Filosofia e, dado o seu caráter de modelo padrão, também das demais faculdades de Filosofia, Ciências e Letras instaladas no país, se organizaram em duas modalidades: o bacharelado, com a duração de três anos, e a licenciatura. O curso de Pedagogia foi definido como um curso de bacharelado ao lado de todos os outros cursos das demais seções da faculdade. O 
diploma de licenciado seria obtido por meio do curso de didática, com a duração de um ano, acrescentado ao curso de bacharelado. Está aí a origem do famoso "esquema 3+1" (SAVIANI, 2007, p. 117).

Segundo Saviani (2012, p. 35), foram definidos, para todos os cursos, os respectivos currículos plenos. Para o curso de Pedagogia foi previsto o seguinte currículo:

- $\quad 1^{\mathrm{o}}$ ano: complementos de matemática; história da filosofia; sociologia; fundamentos biológicos da educação; psicologia educacional.

- $\quad 2^{\circ}$ ano: psicologia educacional; estatística educacional; história da educação; fundamentos sociológicos da educação; administração escolar.

- $\quad 3^{\text {o }}$ ano: psicologia educacional; história da educação; administração escolar; educação comparada; filosofia da educação.

Por essa composição curricular se percebia que a disciplina de psicologia educacional se destaca, pois é a única disciplina que figura em todas as séries. Em seguida posicionam-se história da educação e administração escolar, figurando em duas séries. Às demais disciplinas reservou-se apenas um ano de estudo.

O curso de didática, com duração de um ano, compunha-se das seguintes disciplinas: didática geral; didática especial; psicologia educacional; fundamentos biológicos da educação; fundamentos sociológicos da educação; administração escolar. Assim, no caso do bacharel em Pedagogia, para obter o título de licenciado, bastava cursar didática geral e didática especial, uma vez que as demais já faziam parte de seu currículo de bacharelado (SAVIANI, 2012, p. 35).

Para Saviani (2012, p. 36), o modelo implantado com o Decreto n. 1.190, de 1939, instituiu um currículo pleno fechado para o curso de Pedagogia, em homologia com os cursos das áreas de filosofia, ciências e letras e não o vinculando aos processos de investigação sobre os temas e problemas da educação. Com isso, em lugar de abrir caminho para o desenvolvimento do espaço acadêmico da Pedagogia, acabou por enclausurá-lo numa solução que se supôs universalmente válida em termos conclusivos, agravando progressivamente os problemas que se recusou a enfrentar. Com efeito, 
supondo que o perfil profissional do pedagogo já estaria definido, concebeu um currículo que formaria o bacharel em Pedagogia entendido como o técnico em educação que, ao cursar didática geral e espacial, se licenciaria como professor.

Essa estrutura prevaleceu até após a aprovação da primeira Lei de Diretrizes e Bases da Educação Nacional - LDB - n. 4.024, de 20 de dezembro de 1961. Pouco depois, o Parecer CFE 251/62 mantém o curso de bacharelado para formação do pedagogo e o Parecer CFE 292/62 regulamenta as licenciaturas. Uma nova regulamentação para o curso de Pedagogia foi baixada pelo Parecer CFE 262/69, que abolia a distinção entre bacharelado e licenciatura, mas mantinha a formação de especialistas nas várias habilitações. Dessa forma ficou instituída uma base comum de conhecimentos pedagógicos e uma parte diversificada responsável pela formação dos especialistas (PIMENTA, 2011, p. 12).

Segundo Saviani (2012, p. 39), a entrada em vigor da lei da reforma universitária (Lei n. 5.540/68) aprovada em 28 de novembro de 1968 ensejou uma nova regulamentação do curso de Pedagogia, levada a efeito pelo Parecer n. 252/69 do CFE, de autoria de Valnir Chagas, do qual resultou a Resolução CFE n. 2/69, com a seguinte ementa: "Fixa os mínimos de conteúdo e duração a serem observados na organização do curso de Pedagogia”. Argumenta no parecer que a profissão que corresponde ao setor de educação “É uma só e, por natureza, não só admite como exige 'modalidades' diferentes de capacitação a partir de uma base comum". Para o autor, o parecer

Considera, assim, que os diferentes aspectos implicados na formação do profissional da educação podem ser reunidos sob o título geral de curso de pedagogia, que constará de uma parte comum e outra diversificada. A primeira deverá dar conta da base comum e a segunda, das diversas modalidades de capacitação, traduzidas na forma de habilitações (SAVIANI, 2012, p. 39).

Saviani (2012, p. 40) ainda cita que o Parecer também argumenta que, embora o curso comporte várias habilitações, como todas elas resultam de um curso único, devem supor um só diploma. Posiciona-se, ainda, contra a simetria com os demais cursos que formavam professores para o ensino médio, levando a um duplo título: o de bacharel e o de licenciado. Embora propusesse que o título a ser concedido fosse o de 
bacharel, o Plenário do CFE aprovou emenda do Conselheiro D. Luciano Duarte fixando como título único o de licenciado.

A promulgação da Lei 5.692, de 11 de agosto de 1971, fixou as diretrizes e as bases para o ensino de $1^{\circ}$ e $2^{\circ}$ graus, e tornou a escolaridade obrigatória para todas as crianças dos 7 aos 14 anos. Como consequência, houve a expansão das matrículas dos alunos e uma demanda de escolas e de formação de professores a curto prazo, como num efeito "dominó": para formar professores para o $1^{\circ}$ grau, abriram-se cursos de $2^{\circ}$ grau com habilitação para magistério, as licenciaturas curtas para formar professores da $5^{\circ}$ à $8^{\circ}$ série, os cursos de Pedagogia para formar professores para o magistério de $2^{\circ}$ grau.

Saviani (2007, p. 120) afirma que essa regulamentação do Curso de Pedagogia, não obstante as tentativas de modificação, de iniciativa do próprio Conselho Federal de Educação e do movimento organizado dos educadores, permaneceu em vigor até a aprovação da nova Lei de Diretrizes e Bases da Educação Nacional (n. 9.394), em 20 de dezembro de 1996. O aspecto mais característico da referida regulamentação foi a introdução das habilitações visando formar "especialistas" nas quatro modalidades indicadas (Orientação Educacional, Administração Escolar, Supervisão Escolar e Inspeção Escolar), além do professor para o ensino normal. Segundo o autor,

[...] a dupla suposição revelou-se inconsistente. Nem as funções correspondentes aos mencionados "especialistas" estavam bem caracterizadas, como o próprio Valnir Chagas irá reconhecer poucos anos depois, nem se poderia dar como constituído um mercado de trabalho demandado aqueles profissionais correspondentes às habilitações propostas. Além disso, a solução dada pelo parecer e respectiva Resolução também não se encaminhou na direção da superação do caráter generalista (SAVIANI, 2012, p. 44).

Saviani (2012, p. 44) ainda pontua que, ao que parece, o problema do encaminhamento que se deu à questão do curso de Pedagogia reside numa concepção que subordina a educação à lógica de mercado. Assim, a formação ministrada nas escolas deveria servir à produtividade social, ajustando-se, o mais completamente possível, às demandas do mercado de trabalho que, por sua vez, são determinadas pelas leis que regem uma sociedade de mercado como esta em que vivemos. Nestas circunstâncias, a questão educativa é reduzida dominantemente à sua dimensão técnica, 
afastando-se o seu caráter de arte e secundarizando, também, as exigências de embasamento científico.

Supõe-se, portanto, que a escola já está devidamente organizada e o ensino funcionando dentro de parâmetros adequados, cabendo ao especialista inserir-se nela para garantir-lhe a eficiência por meio de uma racionalidade técnica que maximize a sua produtividade. Trata-se, em suma, daquilo que Saviani denomina "concepção produtivista de educação", que, impulsionada pela teoria do capital humano formulada nos anos 50 do século XX, se tornou dominante em nosso país a partir do final da década de 1960, permanecendo hegemônica até os dias de hoje.

O movimento dos educadores em torno da problemática da formação dos profissionais da educação materializou-se por ocasião da realização da $1^{\text {a }}$ Conferência Brasileira de Educação, em 1980, quando foi criado o Comitê Pró-Participação na Reformulação dos Cursos de Pedagogia e Licenciatura. Esse comitê transformou-se, em 1983, na Comissão Nacional pela Reformulação dos Cursos de Formação de Educadores - CONARCFE - que, por sua vez, em 1990, se constituiu na Associação Nacional pela Formação dos Profissionais da Educação - Anfope - que continua em atividade (SAVIANI, 2007, p. 123). Para o autor,

\begin{abstract}
A mobilização dos educadores foi importante para manter vivo o debate; articular e socializar as experiências que se realizaram em diferentes instituições; manter a vigilância sobre as medidas de política educacional; explicitar as aspirações, reivindicações e perplexidades que os assaltavam; e buscar algum grau de consenso sobre certos pontos que pudessem sinalizar na direção da solução do problema (SAVIANI, 2012, p. 51).
\end{abstract}

Segundo Saviani (2007, p. 123), em termos concretos emerge do movimento a ideia de que a docência é o eixo sobre o qual se apoia a formação do educador. A partir dessa ideia prevaleceu entre as instituições a tendência de organizar o curso de Pedagogia em torno da formação de professores, seja para a habilitação magistério, em nível de $2^{\circ}$ grau, seja, principalmente, para atuar nas séries iniciais do ensino fundamental. 
Para Libâneo (2010, p. 50), o movimento de reformulação dos cursos de formação de educadores, representado hoje pela Anfope, produziu ao longo destes anos documentos bastante expressivos do debate, tendo exercido efetiva influência na concepção de formação do professor e na reformulação de currículos em algumas Faculdades de Educação. Para o autor,

No entanto, é forçoso reconhecer que, por insuficiente base teórica, por falta de propostas consensuais dos vários grupos de intelectuais envolvidos, por dificuldades encontradas na própria realidade ou, mesmo, por obstáculos legais, é ainda modesto o nível de alcance de seus objetivos (LIBÂNEO, 2010, p. 50).

A ANFOPE passou a ter existência jurídica em 22 de julho de 1990, porém, sua origem remonta a 1980, com a criação do Comitê Nacional Pró-formação do Educador, cujo objetivo maior era articular as atividades de professores e alunos tendo em vista a reformulação dos cursos de formação docente no Brasil. Esse Comitê, com intensa atuação de 1980 a 1983, realizou vários seminários tanto estaduais quanto regionais, merecendo destaque o Encontro Nacional realizado em novembro de 1983, na cidade de Belo Horizonte, no qual foi aprovado o "Documento de Belo Horizonte".

Na ocasião, o Comitê transformou-se na "Comissão Nacional pela Formação dos Educadores" (CONARCFE), que seria o mediador para acompanhar a continuidade do processo, como também promover o debate sobre a questão. Daí, em 1990 originou-se a “Associação Nacional pela Formação dos Profissionais da Educação" - ANFOPE, responsável pela defesa e manutenção dos cursos de formação de professores (MASSIAS, 2007, p. 40). Segundo Brzezinski,

A ANFOPE é originária do Comitê Pró-formação do Educador, criado em 02/04/1980, durante a reunião que congregou cerca de 200 participantes da I Conferência Brasileira da Educação (CBE). Esta foi convocada pelos educadores brasileiros que aspiravam subverter a tradicional ordem governamental "de cima para baixo" nas decisões sobre as políticas educacionais. A I CBE foi realizada na PUC-SP, sob a organização da Associação Nacional de Educação (ANDE), da Associação Nacional de Pós-graduação e Pesquisa da Educação (ANPEd), do Centro de Estudos Educação e Sociedade (CEDES) e do Centro de Estudos de Cultura Contemporânea (CEDEC) (BRZEZINSKI, 2009, p. 151). 
A CONARCFE realizou ao todo quatro Encontros Nacionais ao longo dos seus sete anos de existência, porém foi a partir do IV e V Encontros Nacionais, ocorridos respectivamente em 1989 e 1990, nos quais se tratou com maior profundidade a concepção e a operacionalização da Base Comum Nacional, que ela se transformou em Associação. A ANFOPE passou a existir no V Encontro Nacional organizado pela CONARCFE e, a partir do VI Encontro Nacional, os demais Encontros foram organizados pela Associação. Nesta nova fase do movimento, como Associação, a mesma buscou o apoio de demais entidades para organizar os novos encontros.

Segundo Massias (2007, p. 51), a partir de 1995, a ANFOPE tenta definir a identidade do curso de Pedagogia, por meio das atividades profissionais em função do mercado de trabalho, tanto o real como o potencial, porém as discussões foram encerradas devido à dificuldade de atribuir funções ao pedagogo. Embora tenha reconhecido a dificuldade de se definir as funções do pedagogo, a ANFOPE deu continuidade à ampliação de suas atribuições, não somente pela abrangência nacional, mas também devido ao acompanhamento contínuo e processual que realizou de diversas propostas curriculares implantadas em diferentes instituições do ensino superior no país. A autora cita que

\footnotetext{
As propostas elaboradas pela ANFOPE podem ser identificadas nos documentos finais dos encontros nacionais, sendo possível apontar que a associação deu prosseguimento em seus trabalhos, ao longo do seu percurso histórico, enfocando a política de formação dos profissionais da educação, na qual estão incluídas as licenciaturas específicas e o curso de Pedagogia (MASSIAS, 2007, p. 52).
}

Desde então, a ANFOPE, historicamente, vem firmando a necessidade de definição de uma política nacional de valorização e profissionalização dos educadores em nosso país, assim como o estabelecimento de um subsistema nacional de formação de profissionais da educação que defina com clareza os vários aspectos relacionados com a formação, a remuneração, a carreira, a progressão e o aprimoramento profissional dos educadores, como condição para a profissionalização e valorização do magistério da educação básica em nosso país.

Pimenta (2004, p. 10) ressalta que é preciso que os cursos assumam a responsabilidade de formar seus pedagogos, com condição legal de inserção no mundo 
social do trabalho (o que é muito diferente de formá-los para o mercado de trabalho), condição para mudarem as formas e os processos de se proceder à educação, ao ensino, às políticas de educação de crianças, jovens e adultos, aos processos educativos formais e não formais, à gestão do ensino e das escolas e instituições educativas e outras demandas sociais necessárias.

Para a autora, o avanço na área da formação de professores, colocando em pauta e apontando caminhos para a construção da identidade docente, dos saberes que o identificam, da profissionalização e da profissionalidade, da formação e das condições de inserção no mundo do trabalho, pode iluminar a área da Pedagogia no que se refere à profissionalização do pedagogo, que não se resume a ser professor das séries iniciais (PIMENTA, 2004, p. 10).

Para Saviani (2012, p. 55), provavelmente esse quadro de crise por que passa o curso de Pedagogia tem a ver com a demora na definição de suas diretrizes curriculares, o que veio a acontecer apenas em 2006, quando nos aproximávamos do décimo aniversário da nova LDB, bem depois, portanto, das demais áreas. Após várias idas e vindas, foi aprovado, em 13 de dezembro de 2005, pelo CNE, o Parecer CNE/CP n. 5/2005. Segundo o autor,

É forçoso reconhecer que as Diretrizes aprovadas se encontram atravessadas por uma ambigüidade que se fazia presente mesmo na primeira versão, quando se havia excluído deliberadamente a formação dos chamados especialistas em educação. Isso porque as funções de gestão, planejamento, coordenação e avaliação, tradicionalmente entendidas como próprias dos especialistas em educação, haviam sido assimiladas à função docente, sendo consideradas atribuições dos egressos do curso de pedagogia, formados segundo as Novas Diretrizes (SAVIANI, 2012, p. 56 - 57).

O espírito que presidiu a elaboração das Diretrizes Curriculares Nacionais do Curso de Pedagogia foi a consideração de que o pedagogo é um docente formado em um curso de licenciatura para atuar na

Educação Infantil e nos anos iniciais do Ensino Fundamental, nos cursos de Ensino Médio, na modalidade Normal, e em cursos de Educação Profissional na área de serviços e apoio escolar, bem como 
em outras áreas nas quais sejam previstos conhecimentos pedagógicos (SAVIANI, 2012, p. 57).

Vê-se, pelos termos em que se encontram vazados os textos do Parecer e da Resolução, que eles se encontram impregnados do espírito dos chamados novos paradigmas que vêm prevalecendo na cultura contemporânea, em geral, e na educação, em particular. Segundo Saviani,

As Novas Diretrizes Curriculares Nacionais do Curso de Pedagogia são, ao mesmo tempo, extremamente restritas e demasiadamente extensivas: muito restritas no essencial e assaz excessivas no acessório. São restritas naquilo que configura a pedagogia como um campo teórico-prático dotado de um acúmulo de conhecimentos e experiências resultantes de séculos de história. Mas são extensivas no acessório, isto é, dilatam-se em múltiplas e reiterativas referências à linguagem hoje em evidência (SAVIANI, 2012, p. 58).

Diante do resultado objetivado nas Diretrizes Curriculares Nacionais do Curso de Pedagogia, poderíamos pensar em fazer uma autocrítica do movimento que desencadeamos em 1980, por ocasião da Primeira Conferência Brasileira de Educação: o movimento não teria sido capaz de concentrar sua atenção nas questões essenciais relativas à formação do educador, de modo geral, e do pedagogo, em especial, tendo se voltado para o aspecto da organização do curso. Em consequência, a excessiva preocupação com a regulamentação, isto é, com os aspectos organizacionais, teria dificultado o exame dos aspectos mais substantivos referentes ao próprio significado e conteúdo da Pedagogia sobre cuja base cabe estruturar o curso correspondente (SAVIANI, 2012, p. 58).

Segundo Saviani (2012, p. 70 - 71), podemos considerar que, do ponto de vista da Pedagogia, as diferentes concepções de educação podem ser agrupadas em duas grandes tendências: a primeira seria composta pelas correntes pedagógicas que dariam prioridade à teoria sobre a prática, subordinando esta àquela, sendo que, no limite, dissolveriam a prática na teoria. A segunda tendência, inversamente, compõe-se das correntes que subordinam a teoria à prática e, no limite, dissolvem a teoria na prática. No primeiro grupo, estariam as diversas modalidades de pedagogia tradicional, sejam elas situadas na vertente religiosa ou na leiga. No segundo grupo, se situariam as diferentes modalidades da pedagogia nova. Dizendo de outro modo, poderíamos 
considerar que, no primeiro caso, a preocupação se centra nas "teorias do ensino", enquanto, no segundo caso, a ênfase é posta nas "teorias da aprendizagem".

Saviani (2012, p. 128) argumenta que em lugar de alimentarmos a polêmica entre as correntes pedagógicas, em especial entre as concepções ditas tradicionais e aquelas renovadas, cabe aceitar o convite para entrar na fase clássica, que é aquela em que já se deu uma depuração, ocorrendo a superação dos elementos da conjuntura polêmica com a recuperação daquilo que tem caráter permanente porque resistiu aos embates do tempo.

\subsection{Currículo e o Curso de Pedagogia da UnB}

O projeto de criação da Faculdade de Educação (FE) é datado de 1962, possuindo o objetivo de oferecer disciplinas pedagógicas aos bacharéis que desejassem cursar a licenciatura para atuar no ensino médio; oferecer pós-graduação em Educação; formar os professores, após o curso introdutório, para a escola elementar e normal, em três anos; formar especialistas em administração, programas e currículos, estatística educacional e em testes de medidas educacionais (BRZEZINSKI, 1997b, p. 44)

A Faculdade de Educação institui estatuto e regimento próprios no ano de 1970, a partir dos quais começa a oferecer o curso de Pedagogia sob as regulamentações das leis 5540/68 e 5692/71. O curso de Pedagogia foi reconhecido pelo decreto $\mathrm{n}^{\circ}$ 70.728 de 19 de dezembro de 1972. As habilitações oferecidas na época abrangiam a Supervisão Escolar; Orientação Educacional; Administração Escolar; Inspeção Escolar; Magistério das Matérias Pedagógicas de $2^{\circ}$ grau e, a partir de 1974, passou a oferecer a habilitação de Tecnologia Educacional. Segundo Menezes (1989), a Faculdade de Educação sustentava-se, em sua organização acadêmico-administrativa, em três departamentos: Planejamento e Administração (PAD), Teorias e Fundamentos (TEF) e Métodos e Técnicas (MTC). Essa estrutura organizacional prevalece na FE até os dias atuais (UNB, 2012, p. 4).

Segundo seu projeto político-pedagógico (UnB, 2012, p. 5), a Faculdade de Educação foi escolhida para sediar o I Seminário de Educação da Região Centro-Oeste, 
em 1986, haja vista sua postura de vanguarda em relação a temas polêmicos da sociedade brasileira. Esse seminário tornou-se um marco para a compreensão da posição da FE/UnB no processo de reformulação do curso de Pedagogia quando foram traçados os seguintes princípios: o enfoque político, social e pedagógico do currículo; a Pedagogia no sentido global; o projeto institucional inserido socialmente, prevalecendo como tema de discussão do encontro a relação educação e sociedade; a autonomia universitária; a formação do educador e do especialista em educação.

Conforme o PPP, (UnB, 2012, p. 5), o documento gerado desse encontro solicitava prioridades curriculares e previa discussão acerca da formação do educador e de seu compromisso com a realidade social do país. Em meio a um contexto de tensões, a Faculdade de Educação da UnB implanta seu curso de Pedagogia com vistas à formação de técnicos em habilitações previstas em lei.

Posteriormente à criação de seu curso de Pedagogia, a FE cria a habilitação em Tecnologia Educacional e seu primeiro laboratório de Tecnologia Educacional; a princípio mantém uma integração com a Fundação Educacional do Distrito Federal (FEDF), de onde foi proporcionada a criação de cursos de extensão na área de formação das novas especialidades; oferecimento de cursos de assessoramento didáticopedagógico a professores de outras unidades acadêmicas, integrando-se com toda a UnB (MENEZES, 1989, p. 110).

No projeto político-pedagógico da FE (UnB, 2012, p. 6), consta a existência de visões diferentes a respeito da missão do curso de Pedagogia. Uma das visões relacionava o curso ao mercado de trabalho, com a proposição de reajustes ao curso existente e configurando uma tendência técnico-legal de abordagem do currículo. E outra visão que prezava pela formação do profissional da educação, apoiando a reformulação global do curso, em outra perspectiva de abordagem curricular. Em 1984, foi realizado o II Seminário: "A Faculdade de Educação da UnB e a formação dos Profissionais da Educação". Desse encontro originou-se um documento com a proposta de aprofundamento dos debates em torno do curso de Pedagogia.

Em 1988 foram introduzidas mudanças curriculares no curso de Pedagogia por iniciativa do Decanato de Graduação. Esse currículo apresentava como novidade a 
introdução de mais uma habilitação - Formação no Magistério para o Ensino Fundamental - junto com as já existentes. Em 1994, entrou em funcionamento o curso noturno de Pedagogia, oferecendo uma única habilitação - Magistério para Início de Escolarização, aprovado em 1997 nas instâncias superiores da UnB (UnB, 2012, p. 6).

O PPP (UnB, 2012, p. 6) da Faculdade de Educação realça que, com a implantação da licenciatura em Pedagogia, abriu-se um espaço na Faculdade de Educação para examinar as questões ligadas à formação de um aluno trabalhador que superasse as limitações observadas no currículo vigente. Baseado em uma avaliação externa em 1997, um grupo de trabalho foi instaurado para analisar o currículo em vigor na FE. Desse debate foram destacados vários aspectos que seriam objeto de reflexão sobre a formação do aluno no Curso de Pedagogia. Emerge a necessidade de passar a considerar a formação inicial em um único curso, sem distinção entre os turnos diurno e noturno. Em meio a tudo isso as políticas de formação determinaram que os créditos em disciplinas obrigatórias não poderiam ultrapassar $70 \%$ do total.

A fim de regulamentar essa política, a Câmara de Ensino Pesquisa e Extensão (CEPE) aprovou a Resolução 219/96. Devido à repercussão da Resolução, os docentes da FE reunidos em plenária decidiram proceder a uma reformulação profunda do curso, em vez de ajustes na contabilidade dos créditos. Em agosto de 1997 iniciou-se a reformulação curricular do curso de Pedagogia, por meio de diversos encontros internos da comunidade. Foi definido o quadro de referência empírica, constituindo-se grupos de trabalho para subsidiar a Câmara Setorial de Graduação. Este processo culminou na aprovação do currículo no ano de 2002, vigente até a atualidade, estando também em processo de rediscussão junto à Comunidade da FE (UnB, 2012, p. 7).

As atividades educacionais a distância na Universidade de Brasília tiveram início em pleno regime militar e intervenção na UnB, na década de setenta do século XX. A Faculdade de Educação (FE) foi pioneira neste segmento. Em 1975 criou a habilitação em Tecnologia Educacional e em 1979 estabeleceu convênio com a Open University, com o objetivo de criação da Universidade Aberta do Brasil (UAB). Ainda no século XX, na década de noventa, a FE implementou o Consórcio Interuniversitário de Educação Continuada e a Distância - BRASILEAD, que congregou um número significativo de universidades públicas e foi considerado o embrião da Universidade 
Virtual Pública do Brasil - UNIREDE. Em 1996, A Faculdade de Educação da UNB iniciou a oferta do Curso de Especialização em Educação Continuada e a Distância apoiada pela Cátedra da Unesco de Educação a Distância e do Ministério da Educação/MEC.

O curso de Pedagogia a distância adota a metodologia ancorada no decreto 5.622/05. Faz-se utilização do Ambiente Virtual de Aprendizagem (AVA) e adoção do modelo semipresencial, que conta com encontros presenciais nos polos que ofertam o curso. A formação oportunizada pelo curso de Pedagogia a distância é a mesma da modalidade presencial. Ambas possuem avaliações peculiares, estágios como previstos nas Diretrizes nacionais, defesa de trabalhos de conclusão de curso e atividades relacionadas aos laboratórios de ensino.

O fato de o curso de Pedagogia a distância ser fomentado por meio do Sistema Universidade Aberta do Brasil impõe uma reorientação pedagógica de forma a atender aos critérios da Diretoria de Educação a Distância da Capes. Esse aspecto reflete-se na estrutura do curso, principalmente nas condições da oferta, por exemplo: número de encontros presenciais, vinculação aos polos presenciais, existência da tutoria presencial e a distância, dos coordenadores de polo, gestores do curso, coordenadores de tutoria e do curso. O projeto político-pedagógico do curso de Pedagogia a distância segue o mesmo projeto do ensino presencial, tendo a mesma oferta em relação às disciplinas obrigatórias e optativas, com algumas modificações necessárias a um curso a distância.

\section{METODOLOGIA DE PESQUISA}

Na presente seção, é apresentada a metodologia utilizada na pesquisa: o método, os procedimentos metodológicos, os instrumentos de geração de dados, as entrevistas e os questionários.

Uma investigação tem como ponto de partida o estudo de dúvidas referentes a algum tema, e as suas respostas buscam meios que levam o pesquisador a algum lugar com o seu trabalho científico. Todas as grandes invenções e acontecimentos do homem foram concluídos sempre pelo pressuposto de uma pergunta, de uma dúvida inerente 
que gerou análises para se chegar a uma solução. Gil (2008, p. 8) elucida que a ciência tem como objetivo fundamental chegar à veracidade dos fatos.

Neste sentido, não se distingue de outras formas de conhecimento. O que torna, porém, o conhecimento científico distinto dos demais é que tem como característica fundamental a sua verificabilidade. Para que um conhecimento possa ser considerado científico, torna-se necessário identificar as operações mentais e técnicas que possibilitam a sua verificação. Ou, em outras palavras, determinar o método que possibilitou chegar a esse conhecimento. Gil afirma que

Pode-se definir método como caminho para se chegar a determinado fim. E método científico como o conjunto de procedimentos intelectuais e técnicos adotados para se atingir o conhecimento (GIL, 2008, p. 8).

Segundo Gonsalves (2005, p. 61), o percurso metodológico se refere ao caminho trilhado para que o pesquisador atinja os objetivos que definiu. Nele o pesquisador também deverá explicitar os instrumentos e as fontes de pesquisa que utilizará na investigação. Uma concepção muito difundida - e extremamente reducionista - é aquela que associa metodologia a um conjunto de técnicas e de procedimentos para a geração de dados empíricos. Neste sentido, metodologia significa o caminho a ser percorrido.

No entanto, a questão metodológica é bem mais ampla e indica um processo de construção, um movimento que o pensamento humano realiza para compreender a realidade social. Isso significa que, ao registrar o seu percurso metodológico, você estará evidenciando a sua postura epistemológica enquanto pesquisador, ou seja, você deixará pistas de como está concebendo a relação sujeito-objeto do conhecimento. Para Gonsalves,

Methodos significa o caminho para chegar a um fim, enquanto logos indica estudo sistemático, investigação. Assim, no sentido etimológico, metodologia significa o estudo dos caminhos a serem seguidos, incluindo aí os procedimentos escolhidos (GONSALVES, 2005, p. 62). 
Para se desenvolver um estudo científico se faz necessário redigir um projeto de pesquisa, no qual se destaca todo o planejamento necessário ao entendimento e desenvolvimento do estudo. Nele é muito importante definir o objetivo, o problema, a metodologia, o referencial teórico, a análise e geração de dados, dentre outras definições e procedimentos importantes para se chegar a uma conclusão. Creswell (2010, p. 25) o definiu como sendo

[...] os planos e os procedimentos para a pesquisa que abrangem as decisões desde suposições amplas até métodos detalhados de coleta e de análise dos dados. Esse plano envolve várias decisões, onde a decisão geral envolve qual projeto deve ser utilizado para se estudar um tópico (CRESWELL, 2010, p. 25).

A informação dessa decisão deveria refletir as concepções que o pesquisador traz para o estudo, os procedimentos da investigação (chamados de estratégias) e os métodos específicos de coleta e de análise e interpretação dos dados. A seleção de um projeto de pesquisa é também baseada na natureza do problema ou na questão de pesquisa que está sendo tratada, nas experiências pessoais dos pesquisadores e no público ao qual o estudo se dirige.

A presente dissertação foi desenvolvida como uma pesquisa qualitativa pela característica do objeto de estudo e natureza do problema. Gonsalves (2005, p. 68) relata que a pesquisa qualitativa se preocupa com a compreensão, com a interpretação do fenômeno, considerando o significado que os outros dão às suas práticas. Creswell (2010, p. 28) define a pesquisa qualitativa como sendo um meio para explorar e para entender o significado que os indivíduos ou os grupos atribuem a um problema social ou humano.

Este processo de pesquisa envolve as questões e os procedimentos que emergem, os dados tipicamente coletados no ambiente do participante, a análise dos dados indutivamente construída a partir das particularidades para os temas gerais e as interpretações feitas pelo pesquisador acerca do significado dos dados. O relatório final escrito tem uma estrutura flexível. Aqueles que se envolvem nessa forma de investigação apoiam uma maneira de encarar a pesquisa que honra um estilo indutivo, 
um foco no significado individual e na importância da interpretação da complexidade de uma situação.

A abordagem metodológica adotada para a pesquisa foi o estudo de caso. Para Creswell (2010, p. 38), os estudos de caso são uma estratégia de investigação em que o pesquisador explora profundamente um programa, um evento, uma atividade, um processo ou um ou mais indivíduos. Gonsalves (2005, p. 67) afirma que o estudo de caso é o tipo de pesquisa que privilegia um caso particular, uma unidade significativa, considerada suficiente para a análise de um fenômeno. É importante destacar que, no geral, o estudo de caso, ao realizar um exame minucioso de uma experiência, objetiva colaborar na tomada de decisões sobre o problema estudado, indicando as possibilidades para sua modificação.

De acordo com Gil (2008, p. 57), o estudo de caso é caracterizado pelo estudo profundo e exaustivo de um ou de poucos objetos, de maneira a permitir o seu conhecimento amplo e detalhado, tarefa praticamente impossível mediante os outros tipos de delineamentos considerados. O estudo de caso vem sendo utilizado com frequência cada vez maior pelos pesquisadores sociais, visto servir a pesquisas com diferentes propósitos, tais como:

a) explorar situações da vida real cujos limites não estão claramente definidos;

b) descrever a situação do contexto em que está sendo feita determinada investigação; e

c) explicar as variáveis causais de determinado fenômeno em situações muito complexas que não possibilitam a utilização de levantamentos e experimentos.

\subsection{Os participantes da Pesquisa}

Os participantes da pesquisa são os alunos finalizando o curso de graduação presencial e a distância em Pedagogia ofertado pela Faculdade de Educação da Universidade de Brasília, localizada no Distrito Federal. Quanto aos alunos do curso presencial de Pedagogia, participaram da pesquisa quarenta e quatro alunos dos oitenta 
e sete alunos matriculados no último semestre do curso. Ou seja, os alunos que estavam saindo da faculdade no segundo semestre do ano de dois mil e quinze (2015). Os alunos participantes da pesquisa que cursam Pedagogia na modalidade a distância estavam na fase de construção do trabalho de conclusão de curso (TCC) e estão vinculados aos polos de estudo de Alexânia-GO e Goiás Velho-GO. Em relação aos alunos que cursam Pedagogia na modalidade a distância, participaram vinte e dois alunos de um total de cinquenta e oito matriculados.

Esta pesquisa contou com a participação dos alunos que estavam finalizando o curso de Pedagogia da Universidade de Brasília. Ao todo participaram da pesquisa sessenta e seis (66) alunos, dentre os quais vinte e dois (22) estão matriculados na modalidade de educação a distância e quarenta e quatro (44) estão matriculados no curso presencial ofertado pela Faculdade de Educação. Por questões éticas, não divulgaremos os nomes desses participantes, os quais serão referidos por meio de abreviações [PP1], [PP2], e assim sucessivamente. Todos os gráficos utilizados na pesquisa e na caracterização dos participantes tiveram como fonte os dados coletados na própria pesquisa. Para criação dos gráficos foram utilizados os softwares Planilhas do Google e também o programa Paint que é utilizado para criar desenhos ou editar imagens digitais.

Em relação ao gênero, os percentuais de alunos com gênero masculino e feminino são similares quanto à modalidade de ensino (educação a distância e curso presencial). O curso presencial de Pedagogia apresenta, em sua maioria, pessoas do gênero feminino, quase oitenta e dois por cento (82\%) dos alunos (Gráfico 1). Dado que reflete historicamente a relação da formação docente com uma identidade feminina, denotando o predomínio de mulheres em cursos de educação. Apenas dezoito vírgula dois por cento $(18,2 \%)$ dos alunos afirmaram ser do gênero masculino. 
Gráfico 1 - Gênero dos Alunos do Curso Presencial de Pedagogia

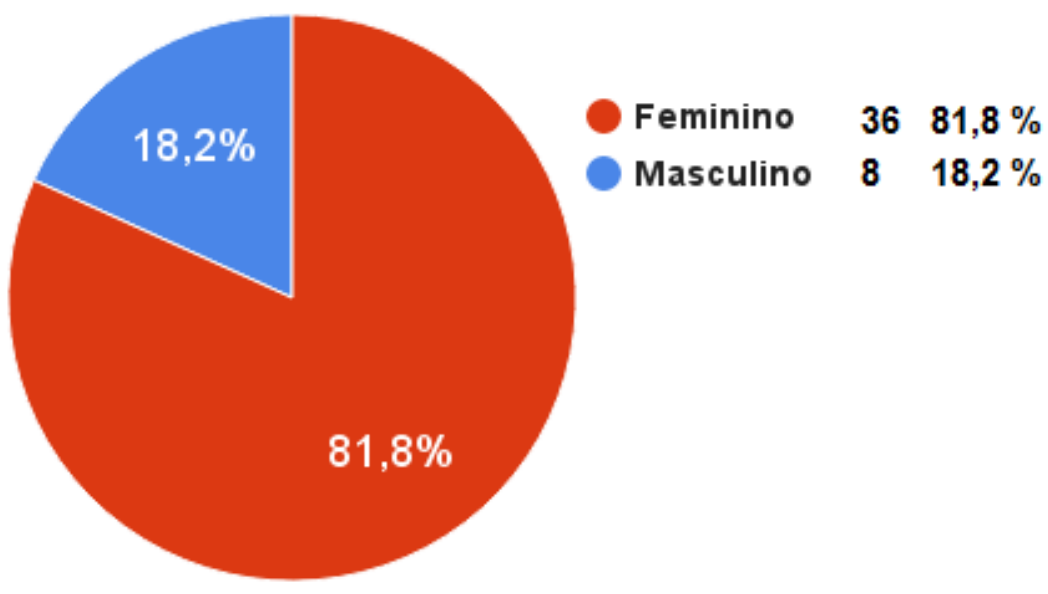

No curso de Pedagogia ofertado a distância os percentuais apresentados em relação ao gênero dos alunos são muito próximos aos encontrados no curso presencial. Dos vinte e dois alunos (22) que participaram da pesquisa (Gráfico 2), dezessete (17) deles, o que equivale a cerca de setenta e sete vírgula três por cento $(77,3 \%)$ dos alunos assinalaram ser do gênero feminino, enquanto apenas vinte e dois vírgula sete por cento $(22,7 \%)$ assinalaram ser do gênero masculino. Interessante observar que mesmo em modalidades de ensino diferentes o predomínio de mulheres nos cursos de Pedagogia se demonstra.

Gráfico 2 - Gênero dos Alunos do Curso a Distância de Pedagogia

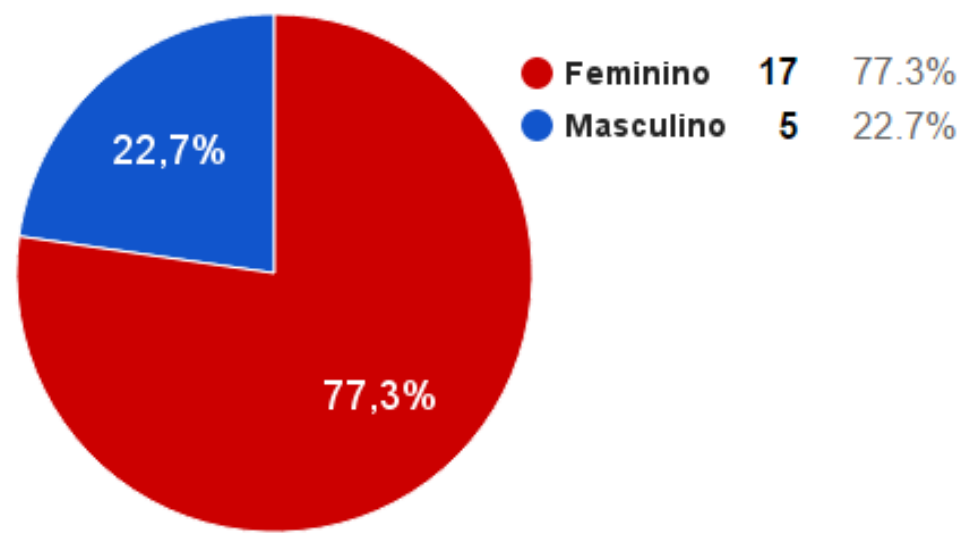

Quanto à renda familiar, pode ser observada uma similaridade entre as características dos alunos das distintas modalidades de ensino (EAD e presencial). A maioria dos alunos que cursam Pedagogia presencialmente, setenta e cinco por cento 
(75\%), possuem uma renda familiar que não ultrapassa seis (6) salários mínimos, Observando que o valor do salário mínimo quando aconteceu a geração de dados equivalia a setecentos e oitenta e oito reais $(\mathrm{R} \$ 788,00)$ (Gráfico 3).

O índice que denota uma maior presença nas respostas é o que expressa uma renda familiar estimada de três a seis $(3-6)$ salários mínimos, para cerca de quarenta e três vírgula dois por cento $(43,2 \%)$ dos alunos. E apenas quinze vírgula nove por cento $(15,9 \%)$ dos alunos, sete (7) participantes, afirmaram possuir uma renda familiar estimada em mais de dez (10) salários mínimos.

Gráfico 3 - Renda Familiar dos Alunos do Curso Presencial de Pedagogia

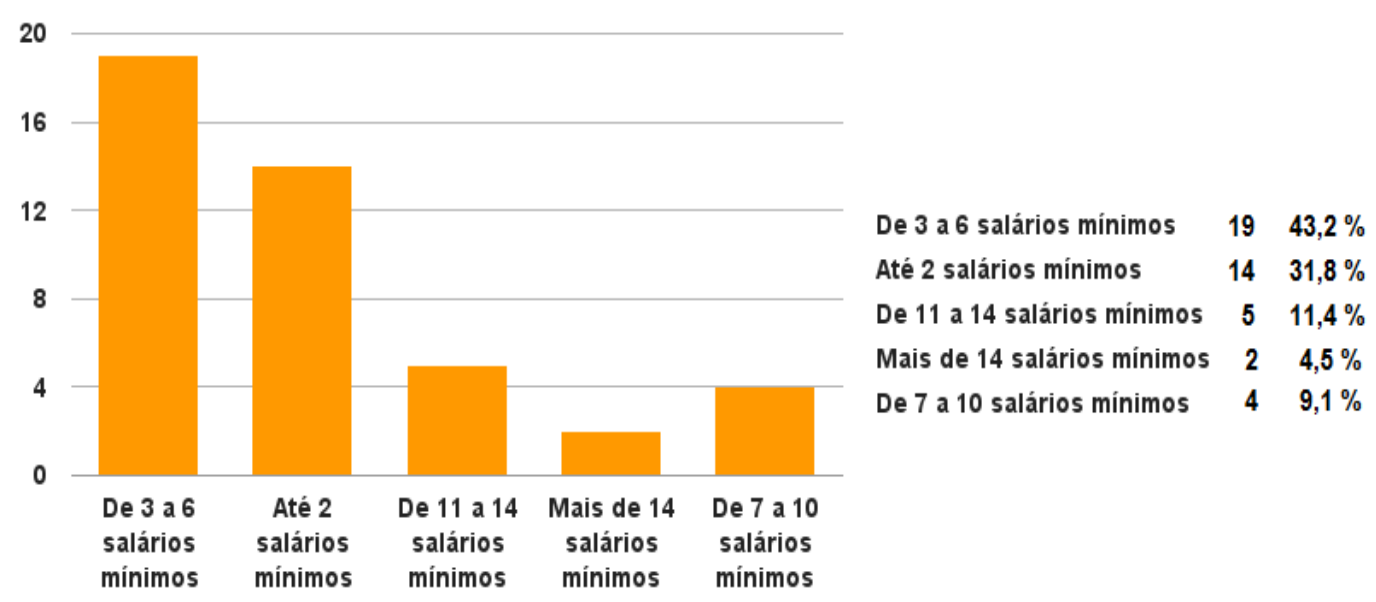

Os dados revelam que os alunos que cursam Pedagogia na modalidade de educação a distância apresentam características muito similares (Gráfico 4) aos alunos que cursam de forma presencial (Gráfico 3). Cerca de setenta e sete vírgula três por cento $(77,3 \%)$ dos alunos, dezessete (17) participantes, afirmaram ter uma renda familiar de até seis (6) salários mínimos, sendo o índice mais acionado nas respostas aquele que expressa que a renda familiar é de até dois (2) salários mínimos, atingindo cinquenta por cento $(50 \%)$ dos participantes.

Somente dois (2) alunos, cerca de nove vírgula um por cento $(9,1 \%)$, assinalaram possuir uma renda familiar acima de quatorze (14) salários mínimos. Podemos observar que a maioria dos alunos que optam pela graduação no curso de Pedagogia apresentam ter uma renda familiar baixa.

Gráfico 4 - Renda Familiar dos Alunos do Curso EAD de Pedagogia 


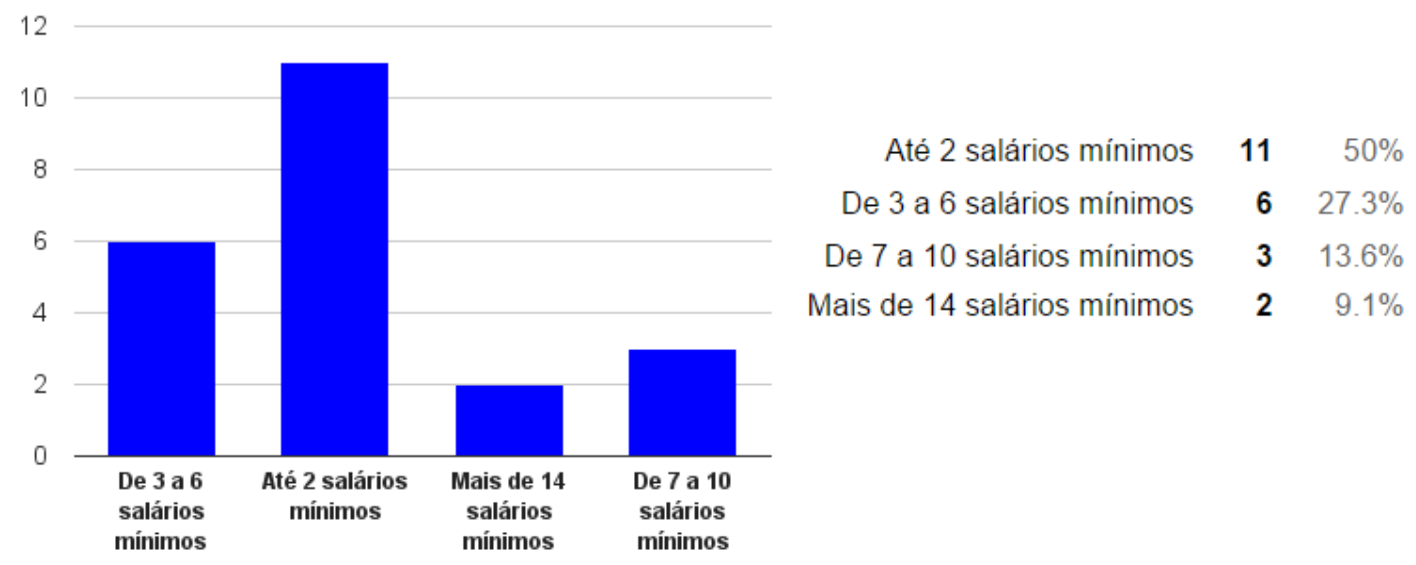

Em relação à idade, temos uma grande diferença no perfil do aluno em relação à modalidade de ensino cursada. No curso presencial de Pedagogia (Gráfico 5) temos cerca de noventa e um por cento (91\%) dos alunos tendo até vinte e sete (27) anos de idade. Observa-se ainda que mais de cinquenta e seis por cento (56\%) dos alunos têm até vinte e dois (22) anos de idade.

Somente quatro (4), dezenove por cento (19\%), dos quarenta e quatro (44) alunos participantes afirmaram ter mais de vinte e oito (28) anos de idade. Lembrando que estes alunos estavam finalizando o curso, último semestre, percebe-se que a maioria deles saíram do ensino médio e ingressaram direto na graduação.

Gráfico 5 - Faixa Etária dos Alunos do curso Presencial de Pedagogia

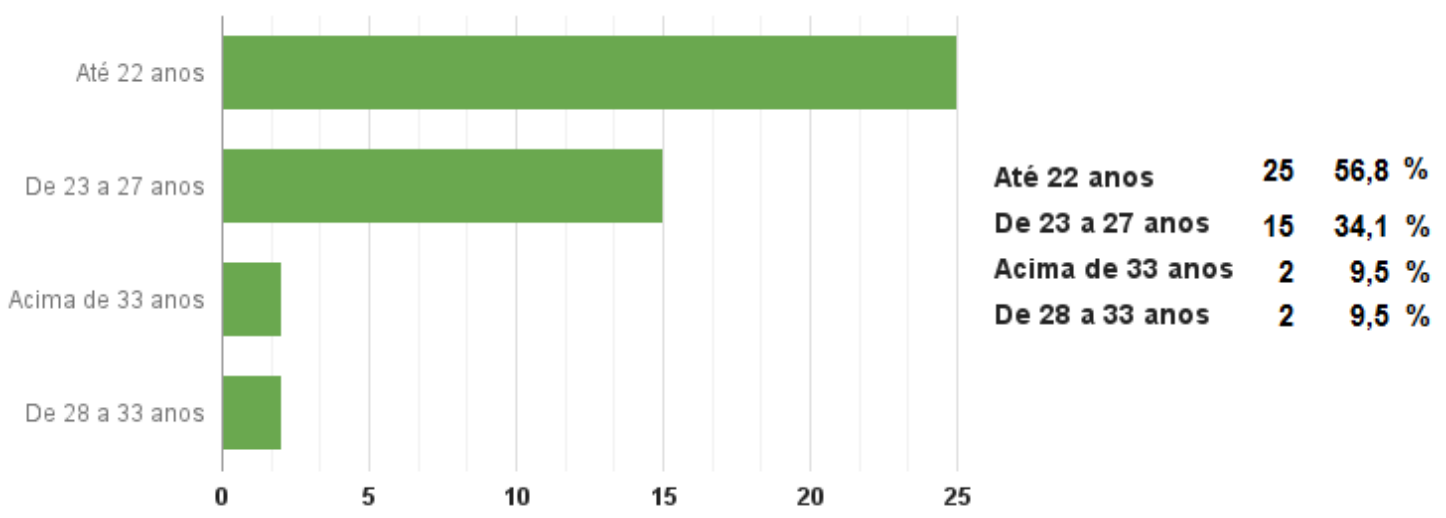

Este perfil é diferente do perfil dos alunos que estão finalizando o curso de Pedagogia na modalidade a distância (gráfico 6). Quase oitenta e dois por cento (82\%) dos participantes têm mais de trinta e três (33) anos de idade. E somente quatro (4) 
participantes, cerca de dezoito por cento (18\%), dos vinte e dois (22) afirmaram ter menos de trinta e três (33) anos de idade.

Aqui o perfil dos alunos indica que a maioria deles optaram por fazer a graduação em Pedagogia em um momento posterior à saída do ensino médio. $\mathrm{O}$ fato de o curso ser ofertado em uma modalidade de ensino mais flexível, no tocante a horários, espaço e forma de funcionamento pode ter contribuído para a escolha da graduação nessa modalidade. Outro fator a ser considerado é a oferta deste curso em locais de difícil acesso à educação e formação, sendo oportunizada então a formação das pessoas da região.

Gráfico 6 - Faixa Etária dos alunos do Curso a Distância de Pedagogia

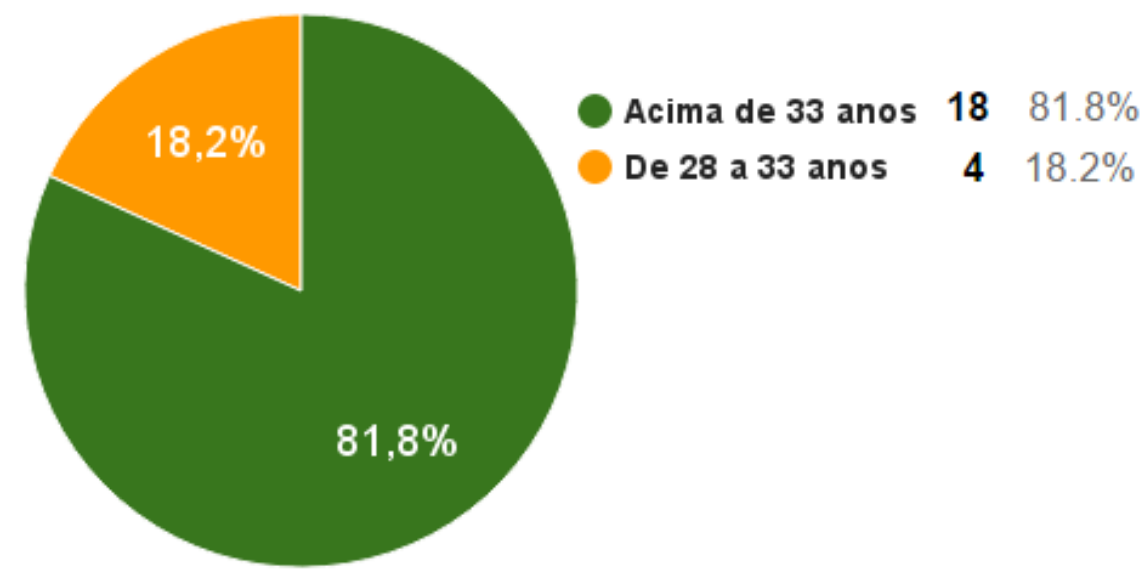

Em relação ao andamento do aluno no curso, há alunos que estão em diferentes períodos. O currículo do curso de Pedagogia presencial ofertado pela Faculdade de Educação possibilita que o aluno monte sua grade horária. Sendo assim, ele pode adiantar matérias para finalizar mais brevemente o curso ou até mesmo em um determinado semestre ou período cursar mais ou menos créditos, lembrando que a faculdade sugere que o aluno siga o fluxo curricular preparado para a orientação dos alunos no decorrer de seus estudos e que existe tempo mínimo e máximo para que o curso seja concluído.

Segundo os participantes da pesquisa, a maioria dos alunos, oitenta e um vírgula oito por cento $(81,8 \%)$, estão matriculados no oitavo período do curso presencial de Pedagogia (Gráfico 7). Devido à flexibilidade do currículo, também participaram da 
pesquisa alunos, cerca de dezoito vírgula dois por cento $(18,2 \%)$, que estavam no sétimo período (um aluno), nono semestre (quatro alunos), décimo semestre (dois alunos) e décimo segundo semestre (um aluno ).

Gráfico 7 - Andamento dos Alunos no Curso Presencial de Pedagogia

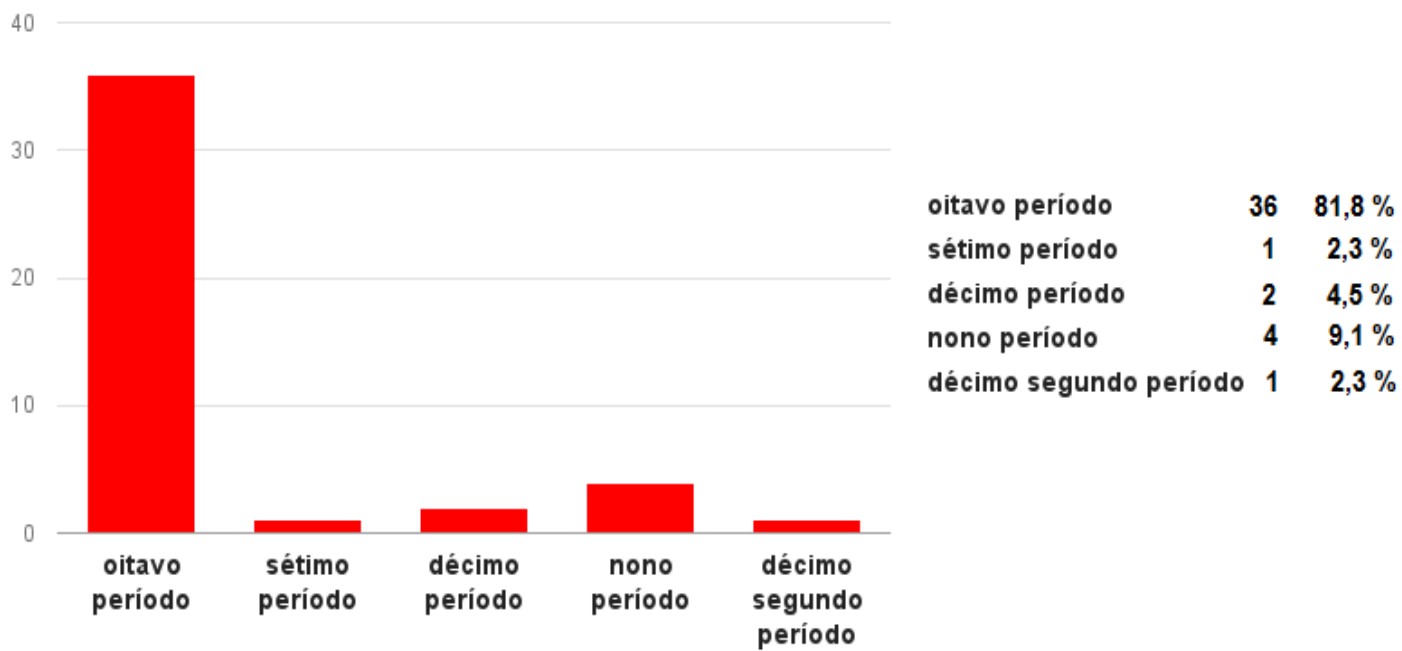

O curso de Pedagogia a distância é o mesmo ofertado de forma presencial, mas conforme as especificidades de um curso ofertado na educação a distância teremos algumas diferenças de funcionamento em relação ao curso presencial. Alguns ajustes se fizeram necessários na forma e funcionamento para maior facilidade e adaptação do curso aos alunos, assim como comumente ocorre em todos os cursos que são ofertados pela EAD.

Cerca de noventa vírgula nove por cento $(90,9 \%)$ dos participantes, vinte alunos (20), estavam cursando o décimo período (Gráfico 8). E apenas nove vírgula um por cento $(9,1 \%)$ dos alunos estavam cursando o oitavo período. Ressalta-se que todos os participantes estavam na fase de elaboração de trabalho de conclusão de curso. 
Gráfico 8 - Andamento dos Alunos no Curso a Distância de Pedagogia

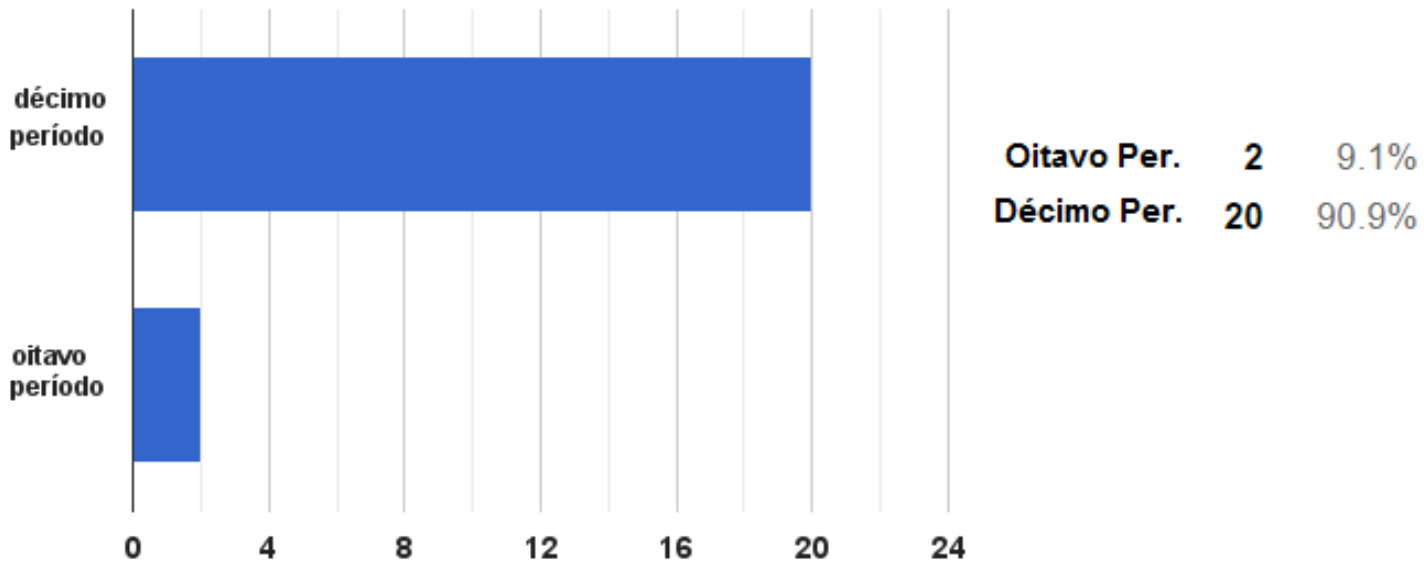

Quanto ao exercício da docência, os alunos das duas modalidades de ensino têm ambições parecidas. A maioria dos alunos participantes da pesquisa, do ensino presencial (Gráfico 9) e do ensino a distância (Gráfico 10), apresentam o desejo de seguir a carreira de professor. Sabe-se que o curso de Pedagogia tem a função de formar professores, mas de acordo com os dados coletados existem alunos que não têm a intenção de exercer a docência.

No curso presencial de Pedagogia quase dezesseis por cento (16\%) dos participantes afirmam que não têm intenção de seguir carreira como professor. Já para trinta e sete alunos, o equivalente a oitenta e quatro vírgula um por cento $(84,1 \%)$, o desejo é seguir a carreira docente (Gráfico 9).

Gráfico 9 - Carreira de Docência: Alunos do Curso Presencial de Pedagogia

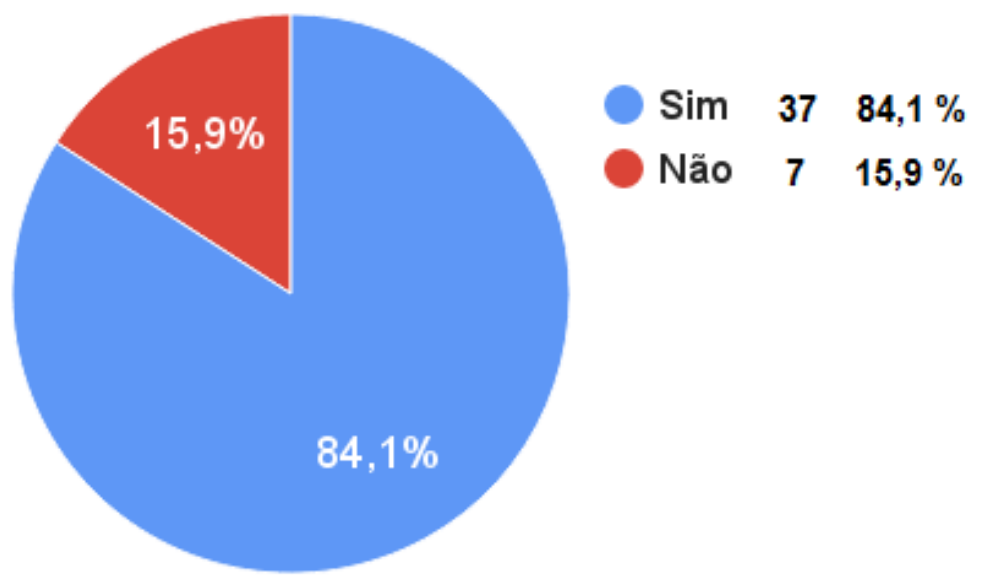


No curso de Pedagogia ofertado a distância, os dados mostram que temos situação similar (Gráfico 10). Cerca de oitenta e seis vírgula quatro por cento $(86,4 \%$ ) dos participantes afirmam que têm intenção de seguir a carreira de professor, mas três (3) dos alunos, treze vírgula seis por cento $(13,6 \%)$ dos participantes, expressaram que não têm a intenção de seguirem a carreira da docência.

Gráfico 10 - Carreira de Docência: Alunos do Curso a Distância de Pedagogia

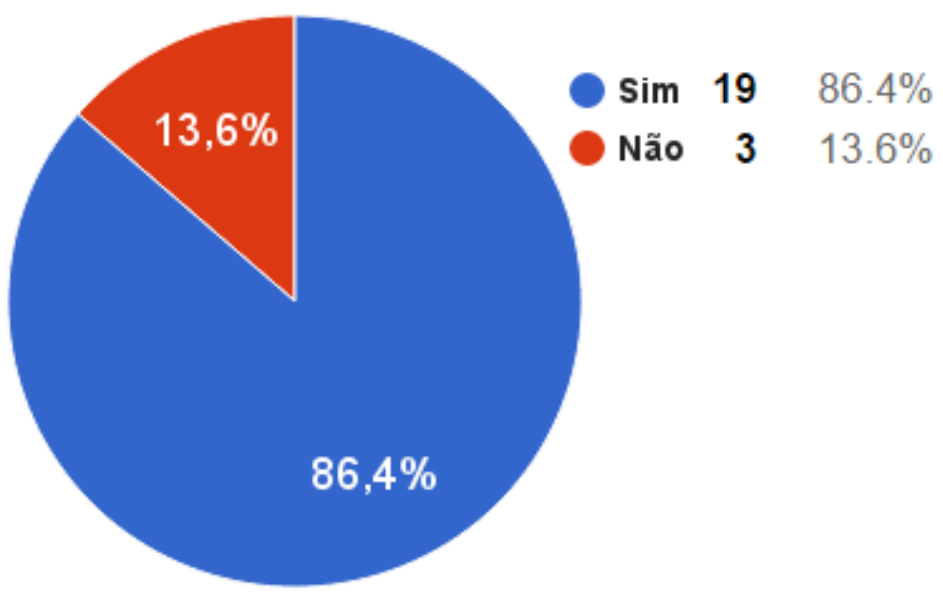

O curso de Pedagogia presencial oportuniza a entrada do aluno em duas turmas. Na oportunidade do seu ingresso ele pode fazer a opção pela turma noturna ou diurna para desenvolver suas atividades. Dos participantes da pesquisa, sessenta e oito vírgula dois por cento $(68,2 \%)$ assinalaram que estão matriculados na turma diurna do curso. Já cerca de quatorze (14) alunos, aproximadamente trinta e um vírgula oito por cento (31,8\%), afirmaram estar matriculados na turma noturna do curso (Gráfico 11).

Gráfico 11 - Turma/Turno do Curso Presencial de Pedagogia

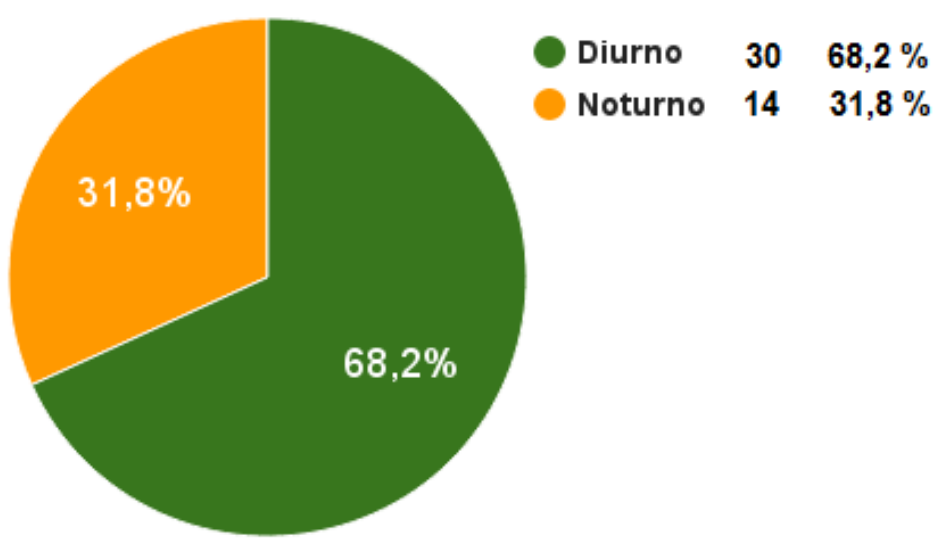


O curso de Pedagogia ofertado na modalidade de educação a distância é ofertado em vários polos que se localizam em diferentes estados brasileiros. Os participantes da pesquisa são originários de dois polos de estudos: um localizado em Alexânia no estado de Goiás e o outro localizado na cidade de Goiás Velho. Cinquenta por cento (50\%) dos alunos, onze (11) participantes, estudam no polo de Alexânia e cinquenta por cento $(50 \%)$ dos alunos estudam no polo de Goiás Velho.

Gráfico 12 - Alunos por Polos do Curso de Pedagogia a Distância

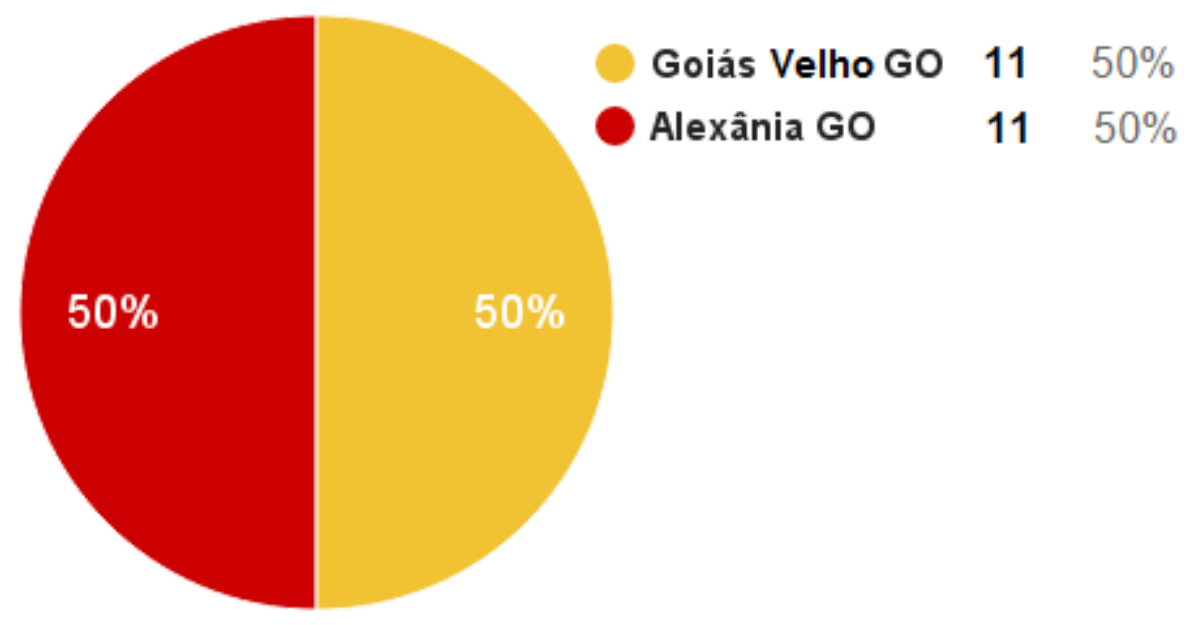

Somente nestes dois polos foram encontradas turmas com alunos em etapa final de curso. Os alunos participantes estão na fase de construção do trabalho final de curso (TCC).

\subsection{Instrumentos e Procedimentos para Geração de Dados}

Para a geração de dados, foram utilizados os seguintes instrumentos e procedimentos: questionário e entrevista semiestruturada.

\subsubsection{Questionário}

O questionário é um dos procedimentos mais utilizados para obter informações. É uma técnica de custo razoável, apresenta as mesmas questões para todas 
as pessoas, garante o anonimato e pode conter questões para atender a finalidades específicas de uma pesquisa.

Aplicada criteriosamente, esta técnica apresenta elevada confiabilidade. Podem ser desenvolvidos para medir atitudes, opiniões, comportamento, circunstâncias da vida do cidadão, e outras questões. Quanto à aplicação, os questionários fazem uso de materiais simples como lápis, papel, formulários, etc. Podem ser aplicados individualmente ou em grupos, por telefone, ou mesmo pelo correio. Podem incluir questões abertas, fechadas, de múltipla escolha, de resposta numérica, ou do tipo sim ou não.

Gil (2008, p. 121) define questionário como a técnica de investigação composta por um conjunto de questões que são submetidas a pessoas com o propósito de obter informações sobre conhecimentos, crenças, sentimentos, valores, interesses, expectativas, aspirações, temores, comportamento presente ou passado etc. Os questionários, na maioria das vezes, são propostos por escrito aos respondentes. Costumam, nesse caso, ser designados como questionários autoaplicados. Quando, porém, as questões são formuladas oralmente pelo pesquisador, podem ser designados como questionários aplicados com entrevista ou formulários.

Segundo Gil (2008, p. 122), a utilização de questionários tem uma série de vantagens. Dentre elas:

a) possibilita atingir grande número de pessoas, mesmo que estejam dispersas numa área geográfica muito extensa, já que o questionário pode ser enviado pelo correio;

b) implica menores gastos com pessoal, posto que o questionário não exige o treinamento dos pesquisadores;

c) garante o anonimato das respostas;

d) permite que as pessoas o respondam no momento em que julgarem mais conveniente;

e) não expõe os pesquisados à influência das opiniões e do aspecto pessoal do entrevistador. 
Construir um questionário consiste basicamente em traduzir objetivos da pesquisa em questões específicas. As respostas a essas questões é que irão proporcionar os dados requeridos para descrever as características da população pesquisada ou testar as hipóteses que foram construídas durante o planejamento da pesquisa. Assim, a construção de um questionário precisa ser reconhecida como um procedimento técnico cuja elaboração requer uma série de cuidados, tais como: constatação de sua eficácia para verificação dos objetivos; determinação da forma e do conteúdo das questões; quantidade e ordenação das questões; construção das alternativas; apresentação do questionário e pré-teste do questionário (GIL, 2008, p. 121).

A aplicação do questionário, nesta pesquisa, teve a finalidade de conseguir um levantamento amplo de dados para identificar o envolvimento dos alunos no último semestre do curso de Pedagogia com as TDICE em sua formação, na perspectiva de caracterizar os participantes e analisar se o curso de Pedagogia da UNB tem proporcionado, na formação do futuro professor, sua inclusão digital.

Os questionários foram aplicados de forma individual a cada participante da pesquisa, aluno do curso presencial de Pedagogia que se dispôs a participar do estudo. Quanto à aplicação do instrumento, a proposta foi pedir autorização aos professores do curso de Pedagogia da UNB para utilizar um intervalo de tempo nas disciplinas ofertadas na Faculdade de Educação onde o fluxo de alunos finalizando o curso fosse maior. Os questionários, sob anuência dos professores, foram submetidos aos alunos no início da aula e recolhidos ao fim do horário. As questões da proposta do questionário, que segue abaixo, tiveram como objetivo:

\begin{tabular}{|l|l|}
\hline Questionário - TECNOLOGIAS NA FORMAÇÃO DO PEDAGOGO \\
\hline Questões & Objetivo \\
\hline $1-3$ & Pesquisar sobre a estrutura tecnológica disponibilizada aos alunos. \\
\hline $4-9$ & $\begin{array}{l}\text { Pesquisar sobre as possibilidades curriculares disponibilizadas na } \\
\text { formação dos alunos para lidar com as TDICE. }\end{array}$ \\
\hline $10-15$ & Pesquisar sobre a didática dos professores do curso. \\
\hline $16-17$ & $\begin{array}{l}\text { Obter avaliação da FE/UNB enquanto promotora da inclusão digital } \\
\text { de seus alunos. }\end{array}$ \\
\hline $18-20$ & $\begin{array}{l}\text { Obter avaliação sobre conhecimentos/habilidades adquiridas para } \\
\text { lidar com as TDICE pelos alunos. }\end{array}$ \\
\hline $21-24$ & Caracterização dos participantes da pesquisa. \\
\hline
\end{tabular}


A estratégia adotada para aplicação dos questionários foi alterada conforme as dificuldades que foram sendo encontradas no percurso da geração de dados. A princípio a estratégia definida para a aplicação dos questionários aos alunos participantes que cursavam Pedagogia na modalidade presencial era em formato impresso. A estratégia planejada era visualizar na grade curricular do curso aquelas disciplinas que teriam um maior fluxo de alunos em etapa final de curso matriculados. Para conhecer essas disciplinas utilizamos o fluxo curricular do curso, no qual estava sugerido quais disciplinas deviam ser cursadas naquele período.

A estratégia adotada não teve uma resposta satisfatória, pois poucos alunos em no último semestre de curso estavam sendo encontrados para participarem da pesquisa. Foi constatado que muitos alunos já tinham cursado tais disciplinas e também que algumas disciplinas possuíam poucos encontros presenciais. Foi percebido um fluxo de alunos formandos próximo à secretaria do curso para resolver problemas referentes à formatura e conclusão de curso; assim, foi encontrado um número razoável de alunos que manifestaram interesse em participar da pesquisa.

Para alcançar um maior número de participantes, uma nova estratégia foi desenvolver o questionário em formato digital utilizando o software Planilhas do Google e disponibilizar o link para a participação dos alunos através dos grupos de Whatsapp e nos grupos de alunos encontrados nas redes sociais (Facebook).

A estratégia adotada para aplicação do questionário de pesquisa aos alunos que cursavam Pedagogia na modalidade a distância foi através do envio por email do link do questionário digital para os alunos que estavam em fase final de curso, desenvolvendo o trabalho de conclusão de curso. A lista com os nomes desses alunos foi conseguida mediante contato com a coordenadora de graduação a distância.

\subsubsection{Entrevista semiestruturada}

Foi empregada para captar a percepção dos alunos do curso presencial de Pedagogia da Universidade de Brasília sobre a inserção das TDICE na sala de aula e seu preparo para uma docência mediada pelas novas tecnologias. 
Pode-se definir entrevista como a técnica em que o investigador se apresenta frente ao investigado e lhe formula perguntas, com o objetivo de obtenção dos dados que interessam à investigação. A entrevista é, portanto, uma forma de interação social. Mais especificamente, é uma forma de diálogo assimétrico, em que uma das partes busca coletar dados e a outra se apresenta como fonte de informação (GIL, 2008, p. 109).

A entrevista é uma das técnicas de geração de dados mais utilizadas no âmbito das ciências sociais. Psicólogos, sociólogos, pedagogos, assistentes sociais e praticamente todos os outros profissionais que tratam de problemas humanos valem-se dessa técnica, não apenas para geração de dados, mas também com objetivos voltados para diagnóstico e orientação.

Gil (2008, p. 110) salienta que a intensa utilização da entrevista na pesquisa social deve-se a uma série de razões, entre as quais cabe considerar:

a) a entrevista possibilita a obtenção de dados referentes aos mais diversos aspectos da vida social;

b) a entrevista é uma técnica muito eficiente para a obtenção de dados em profundidade acerca do comportamento humano;

c) os dados obtidos são suscetíveis de classificação e de quantificação.

A entrevista ainda apresenta outras vantagens na geração de dados, servindo como uma fonte muito importante para corroboração e/ou confrontamento de dados obtidos através dos questionários:

a) não exige que a pessoa entrevistada saiba ler e escrever;

b) possibilita a obtenção de maior número de respostas, posto que é mais fácil deixar de responder a um questionário do que negar-se a ser entrevistado;

c) oferece flexibilidade muito maior, posto que o entrevistador pode esclarecer o significado das perguntas e adaptar-se mais facilmente às pessoas e às circunstâncias em que se desenvolve a entrevista; 
d) possibilita captar a expressão corporal do entrevistado, bem como a tonalidade de voz e ênfase nas respostas.

Esclarece-se que cada um dos participantes entrevistados teve que preencher o Termo de Consentimento Livre e Esclarecido (TCLE), conforme orienta o código de ética nas pesquisas. Desse modo, a entrevista foi utilizada para recolher dados descritivos na linguagem do próprio participante, permitindo ao investigador desenvolver intuitivamente uma ideia sobre a maneira como os participantes interpretam aspectos de sua formação. E, assim, ser possível ter uma visão mais aprofundada da formação do pedagogo e sua relação com as tecnologias.

Para tanto, propôs-se que as entrevistas tivessem um roteiro pré-definido, com base no referencial teórico, e que fossem gravadas em áudio, com duração prevista para, aproximadamente, vinte e cinco minutos, sendo organizadas por um roteiro de perguntas definido, disponível apenas ao pesquisador. Planejou-se que para a fase de entrevista fossem selecionados de forma aleatória cerca de dez alunos em etapa final do curso de Pedagogia. Os alunos foram selecionados aleatoriamente com base no perfil apresentado pelo público-alvo, alunos formandos. Sendo assim, a amostra que passará a entrevista semiestruturada se constituirá em um reflexo do público-alvo.

Apesar de a estrutura estar definida, as perguntas têm o objetivo de ser uma conversa individual, dividida em temáticas, desenvolvidas a partir de temas que permeiam os objetivos específicos de pesquisa. Quanto ao local da entrevista, a proposta foi que as mesmas fossem conduzidas no contexto da pesquisa, a Faculdade de Educação.

As entrevistas com os alunos do curso presencial de Pedagogia aconteceram na Faculdade de Educação na Universidade de Brasília, no Distrito Federal. Ao todo foram entrevistados sete alunos, dos quais quatro eram da turma do diurno e três estavam matriculados na turma noturna. A estratégia adotada para a entrevista foi ir ao ambiente de estudos dos alunos e realizar o convite para participação da pesquisa.

A estratégia adotada para a entrevista dos alunos do curso de Pedagogia a distância teve que ser diferente pela especificidade do curso. Como os dois polos com 
participantes ficavam em outro estado, no estado do Goiás, se tornou mais viável a entrevista via internet mediante um software chamado Skype. O Skype é o software que permite que você converse com o mundo inteiro. Milhões de pessoas e empresas usam o Skype para fazer de graça chamadas com vídeo e chamadas de voz, enviar mensagens de chat e compartilhar arquivos com outras pessoas pelo Skype. Ao responder ao questionário, o aluno assinalava se teria a intenção de participar da segunda etapa da pesquisa, que seria a entrevista. Sendo assim, foi enviado um convite a todos os alunos que manifestaram interesse e três deles se propuseram a participar.

\section{ANÁLISE DOS DADOS E DISCUSSÃO}

Após a geração de dados, a fase seguinte da pesquisa é a de análise e interpretação. Estes dois processos, apesar de conceitualmente distintos, aparecem sempre estreitamente relacionados. A análise tem como objetivo organizar e sumariar os dados de forma tal que possibilitem o fornecimento de respostas ao problema proposto para investigação. Já a interpretação tem como objetivo a procura do sentido mais amplo das respostas, o que é feito mediante sua ligação a outros conhecimentos anteriormente obtidos (GIL, 2008, p. 156).

Bardin (2011, p. 35) descreve que, de maneira geral, pode dizer-se que a sutileza dos métodos de análise de conteúdo corresponde aos seguintes objetivos:

- A superação da incerteza: o que eu julgo ver na mensagem estará lá efetivamente contido, podendo esta "visão" muito pessoal ser partilhada por outros? Por outras palavras, será a minha leitura válida e generalizável?

- E o enriquecimento da leitura: se um olhar imediato, espontâneo, é já fecundo, não poderá uma leitura atenta aumentar a produtividade e a pertinência? Pela descoberta de conteúdos e de estruturas que confirmam (ou infirmam) o que se procura demonstrar a propósito das mensagens, ou pelo esclarecimento de elementos de significações suscetíveis de conduzir a uma descrição de mecanismos de que a priori não possuíamos a compreensão? 
A dissertação em questão se valeu da análise de conteúdo baseada em Bardin. A autora esclarece que o método é muito empírico, dependente do tipo de "fala" a que se dedica e do tipo de interpretação que se pretende como objetivo. Não existe coisa pronta em análise de conteúdo, mas somente algumas regras de base, por vezes dificilmente transponíveis. A técnica de análise de conteúdo adequada ao domínio e ao objetivo pretendidos tem de ser reinventada a cada momento, exceto para usos simples e generalizados (BARDIN, 2011, p. 36). A autora conceitua a análise de conteúdo como sendo

Um conjunto de técnicas de análise de comunicação visando obter, por procedimentos sistemáticos e objetivos de descrição do conteúdo das mensagens, indicadores (quantitativos ou não) que permitam a inferência de conhecimentos relativos às condições de produção/recepção destas mensagens (BARDIN, 2011, p. 48).

Bardin (2011, p. 145) realça que a análise qualitativa apresenta certas características particulares. É válida, sobretudo, na elaboração das deduções específicas sobre um acontecimento ou uma variável de inferência precisa, e não em inferências gerais. Pode funcionar sobre corpus reduzidos e estabelecer categorias mais descriminantes, por não estar ligada, enquanto análise quantitativa, a categorias que deem lugar a frequências suficientemente elevadas para que os cálculos se tornem possíveis.

A proposta aqui traçada se baseou na utilização dos dados levantados pelos questionários, que abrangem o grupo de alunos que estarão em fase final de curso, último período, e também pelas entrevistas, realizadas com um conjunto representativo e voluntário dos alunos que estão matriculados no último período do curso de Pedagogia. Os dados foram analisados e confrontados, de modo a apurar as principais percepções dos futuros professores em relação à sua inclusão digital e condição para uma docência mediada pelas TDICE. Propôs-se uma análise reflexiva e crítica destes, visando à interpretação das dimensões da codificação e categorização que possibilitem e facilitem a compreensão e as inferências suscitadas no diálogo.

A criação de categorias obedeceu às boas qualidades defendidas por Bardin (2011, p. 149): propiciar a exclusão mútua, a pertinência, a homogeneidade, a produtividade, a objetividade e a fidelidade. As categorias que balizarão o atendimento 
do objetivo da pesquisa dirão respeito à infraestrutura física disponibilizada pela Faculdade de Educação aos seus alunos, à didática e metodologia de ensino dos professores, às possibilidades curriculares oferecidas pelo curso de Pedagogia, à inserção das tecnologias na educação e sala de aula, à capacidade dos alunos em proporcionar uma docência mediada pelas TDICE.

Os dados analisados emergiram dos temas que serviram de base para o roteiro das entrevistas e do questionário, como, por exemplo, tecnologias na formação do pedagogo (utilizado para obter a percepção dos alunos em relação à sua formação e inclusão digital), tecnologias na educação (perceber qual a percepção dos alunos do curso de Pedagogia em relação à inserção das TDICE na educação), tecnologias na sala de aula (perceber qual a percepção dos alunos em relação à inserção das novas tecnologias na sala de aula) e tecnologias e docência (investigar se os alunos sentem-se preparados para uma docência mediada pelas novas tecnologias, sobretudo no processo de ensino/aprendizagem). Todos os gráficos utilizados na pesquisa e na caracterização dos participantes tiveram como fonte os dados coletados na própria pesquisa. Para criação dos gráficos foram utilizados os softwares Planilhas do Google e também o programa Paint.

\subsection{Infraestrutura Tecnológica e Digital}

Um passo importante para que se possa promover a inclusão digital dos alunos na universidade é a oferta de uma infraestrutura tecnológica e digital aos acadêmicos. Os alunos precisam estabelecer contato com as ferramentas, acessórios e com toda essa gama de dispositivos inovadores. $O$ investimento na infraestrutura tecnológica no ambiente acadêmico se torna uma medida muito importante para a familiarização dos futuros professores com artefatos da cultura digital que está difundida em nossa sociedade e abarca todos os setores e tipos de atividades em nosso dia a dia.

Kenski (2012, p. 21) elucida que a evolução social do homem se confunde com as tecnologias desenvolvidas e empregadas em cada época. Diferentes períodos da história da humanidade são historicamente reconhecidos pelo avanço tecnológico correspondente. A autora ressalta que vivemos em uma época em que o avanço das 
TDICE produz o aumento constante da presença de mensagens textuais, sonoras e visuais em nossas vidas. Segundo a autora, passamos a ter uma relação mais pessoal e dinâmica com a informação e interação mais frequente com as fontes, sejam elas pessoas ou bancos de dados localizados em qualquer lugar do mundo. Graças às articulações entre a informática e as telecomunicações, é possível, hoje, por satélites, fibras etc., o intercâmbio entre pessoas e máquinas a qualquer tempo, em qualquer lugar (KENSKI, 2012, p. 34). Para Gomez (2010, p. 135),

[...] os professores e alunos convivem com a internet, que é mais um dos artefatos culturais a considerar no processo pedagógico. Portanto, não podemos evitar conhecer seu uso e ensinar sobre eles, com eles ou no contexto deles.

O alcance aos dispositivos digitais na graduação evitará o estranhamento dos futuros professores quando estiverem exercendo sua profissão e se depararem com equipamentos tecnológicos, metodologias ou rotinas que fizerem necessária sua aproximação a tais dispositivos. Muitos professores que não tiveram acesso a este contato acabam procurando uma formação e atualização para poderem utilizar tais ferramentas em sua rotina e prática cotidiana. Mas, pode-se perceber que muitos professores, por não terem tido esta aproximação com as TDICE na graduação, evitam sua aproximação e imersão na cultura digital. Em muitos ambientes educacionais ficam amontoadas diversas ferramentas tecnológicas pelo fato de nenhum professor saber como as utilizar. Behrens (2013, p. 112) chama a atenção dos docentes que não se preocupam em se atualizar ou procurar por uma formação continuada quando relata que

“[...] O professor não pode se furtar de articular projetos de aprendizagem que envolvam tecnologia, principalmente quando ela já está disponível nas suas instituições de ensino".

A utilização das TDICE na escola pode ser muito útil para diversos tipos de atividades. Um dos grandes beneficiados é o professor. Tais tecnologias proporcionam uma grande facilidade e agilidade na preparação de aulas, busca por informações e pesquisas escolares, preparação de material pedagógico (atividades, avaliações, apresentações, etc.) e principalmente quando utilizada para propiciar o ensino/aprendizagem. Segundo Kenski (2012, p. 103), 
O uso criativo das tecnologias pode auxiliar os professores a transformar o isolamento, a indiferença e a alienação com que costumeiramente os alunos freqüentam as salas de aula, em interesse e colaboração, por meio dos quais eles aprendam a aprender, a respeitar, a aceitar, a serem pessoas melhores e cidadãos participativos.

A autora ainda pontua que o professor precisa ter consciência de que sua ação profissional competente não será substituída pelas tecnologias. Elas, ao contrário, ampliam o seu campo de atuação para além da escola clássica. $\mathrm{O}$ espaço profissional dos professores, em um mundo em rede, amplia-se em vez de se extinguir (KENSKI, 2012, p. 104).

Entretanto, não podemos atribuir somente ao investimento em infraestrutura tecnológica e digital o sucesso de um projeto de inclusão digital dos acadêmicos de uma universidade. $\mathrm{O}$ aporte na infraestrutura se faz muito importante, mas para o sucesso do projeto de inclusão também será necessária a formação dos alunos para lidarem com tal cultura e aparatos tecnológicos. É evidente que o investimento somente na parte física, na infraestrutura, não garante o sucesso de um empreendimento de inclusão digital. Só fornecer as ferramentas não funciona, é preciso proporcionar o entendimento em relação às ferramentas, ao processo de utilização e ao funcionamento, além de ensinar como se usa.

Sabe-se que muitas das políticas públicas de Inclusão Digital são baseadas somente no investimento em infraestrutura física de dispositivos digitais. Não deixa de ser um pontapé inicial. O problema é que normalmente tais investimentos públicos param somente nesta etapa: equipar a escola com dispositivos digitais. Temos que dar um passo adiante e prover também a formação dos futuros professores para prepará-los para a docência nesta era tecnológica.

Lacerda Santos e Firmino (2014, p. 45) chamam atenção para o modo como as políticas públicas para promoção da inclusão digital estão organizadas. Segundo os autores, a democratização do acesso às TDICE basicamente acontece de duas maneiras: a primeira é garantindo o acesso aos dispositivos computacionais, através de incentivos para a aquisição; a segunda é pela presença de telecentros nas comunidades com menor distribuição de renda, e por meio de programas de ampliação da banda larga à internet. 
Para os autores, a concepção de inclusão digital implícita nas políticas públicas de inclusão digital,

[...] está baseada em esforços do Governo Federal em universalizar a penetração das TDICE em todas as esferas sociais. Desta forma, acredita-se que, a posse de equipamentos e sistemas aliados a programas de ampliação da oferta de internet, é suficiente para a inclusão digital destes indivíduos (LACERDA SANTOS e FIRMINO, 2014, p. 45).

Foi feito uma pesquisa perante aos alunos do curso de Pedagogia nas modalidades presencial e a distância da UNB acerca da opinião deles em relação à infraestrutura tecnológica e digital oportunizada pela Faculdade de Educação para a utilização da comunidade acadêmica durante a formação no curso. Aqui foi analisado a que tipos de equipamentos e dispositivos digitais e tecnológicos os alunos tiveram acesso, o estado de conservação da infraestrutura e como se dava a forma de acesso a estes dispositivos. Os gráficos utilizados para análise da infraestrutura tecnológica e digital tiveram como fonte os dados coletados na pesquisa por meio dos questionários e entrevistas. Para criação dos gráficos foram utilizados os softwares Planilhas do Google e também o programa Paint. Em relação a que tipos de equipamentos os alunos tiveram acesso ou fizeram uso durante sua graduação, temos uma particularidade em relação à modalidade de ensino estudada pelas suas especificidades. Em relação ao curso presencial, a maioria dos alunos, quarenta e dois (42) dos quarenta e quatro participantes (44), o que equivale a noventa e cinco vírgula quarenta e cinco por cento $(95,45 \%)$, assinalaram que tiveram acesso ou fizeram uso dos computadores e internet disponibilizados pela Faculdade de Educação e UNB (Gráfico 13) e (Gráfico 14).

\section{Gráfico 13 - Acesso ao Computador (Curso Presencial)}

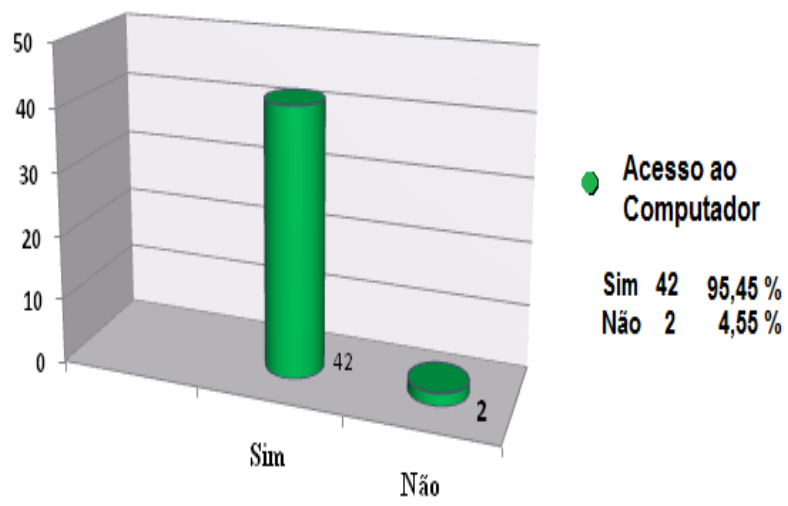


Gráfico 14 - Acesso à internet (Curso Presencial)

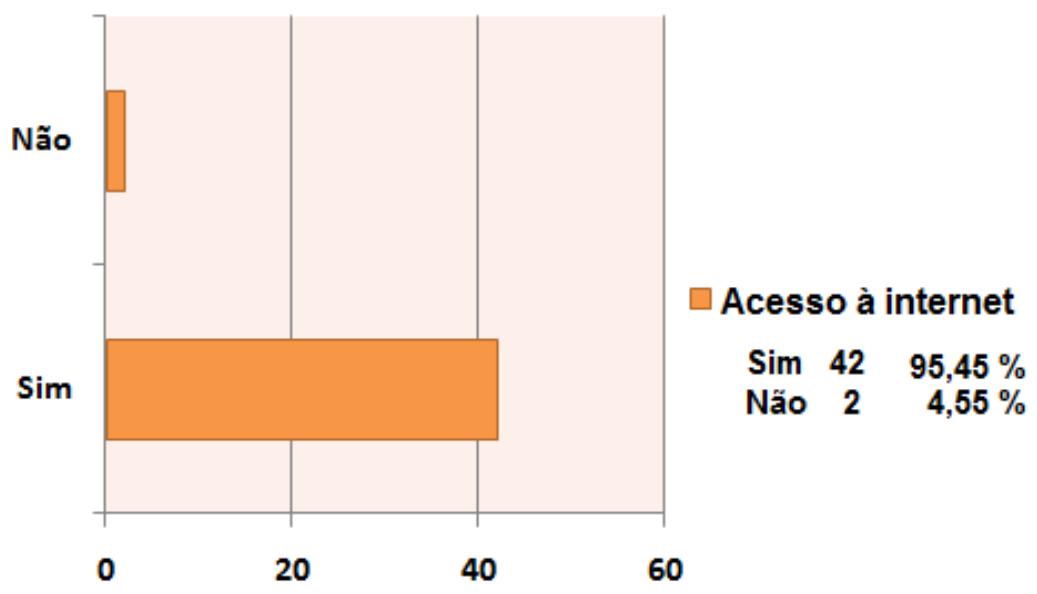

É importante ressaltar que, de acordo com os participantes da pesquisa, a FE oportunizou o acesso ao computador para auxiliar nas atividades acadêmicas. $\mathrm{O}$ computador, juntamente com a internet e seus recursos, é uma ferramenta muito poderosa de informação, comunicação e expressão. Quando levada para o ambiente educacional de forma planejada e pensada, tende a agregar muito valor às atividades desenvolvidas na escola. Quanto à forma do acesso aos computadores e internet, surge uma grande crítica dos alunos sobre a infraestrutura oferecida aos acadêmicos para utilização (Gráfico 15). A maioria dos participantes apontou que têm um acesso limitado aos computadores e internet. Aqui foi ressaltada a quantidade insuficiente de computadores, mal estado de conservação, ambiente inadequado onde se localizam os computadores e link de internet lento e de baixo alcance. Algumas falas dos alunos, extraídas das entrevistas, relatam a opinião deles em relação à disponibilidade e forma de acesso aos computadores e internet.

PP1: Tem mais assim, o nosso laboratório mesmo tem vários computadores, mas cinco funciona. É uma sala inteira cheia de computador, mas nem todos funcionam. Os que funcionam, nem todos têm internet. É muito precário assim, essa... tem espaço, tem material, mas nem todo material funciona! Até a internet mesmo, tem internet, mas a internet não é boa.

PP2: Então, aqui na faculdade a gente não tinha um laboratório de informática pros alunos da Pedagogia, tinha uns computadores ali em baixo, mas nem sempre os computadores funcionavam, nem sempre tinha internet disponível, não era suficiente... não era de quantidade suficiente pra demanda de aluno. 
PP3: Eu acho péssimo, eu acho que FE por exemplo, tem o mínimo disso né. Tem uma sala que deve ter quatro computadores com contingente com mais de 1.500 estudantes, eu acho, e que tem hoje 500 alunos da Pedagogia e outros. Acho que não tem recurso, a internet também é limitada, e quanto a recurso material e físico assim eu acho muito ruim.

PP4: Eu particularmente eu acho que é péssima aqui, eu tô dependendo mesmo de computadores pra fazer TCC aqui da universidade, esses dias uma lâmpada quase caiu na minha cabeça ali na sala, não é a questão do computador assim, mas a sala que também leva em conta. Quando eu comecei a usar tinha uns cinco computadores funcionando, depois quatro, três, no final só tinham dois e a gente disputando por computador. E aqui é um lugar de busca por conhecimento, então eu acho que é alguma coisa que devia tá aberto e tal. Wifi, funciona num prédio num funciona no outro, os professores num têm acesso, a gente quer apresentar um trabalho a gente não tem acesso, então é super complicado.

PP5: Assim, é uma coisa muito restrita, a gente tem essa internet, mas é bem devagar a internet, então acho, por exemplo, eu mudei casa, então eu fiquei um tempo sem internet, fazer meus trabalhos. É muito difícil porque quando todo mundo tá usando o computador, você não tem acesso a outros computadores e tem uma sala de aula de informática que fica fechada.

PP6: É muito fraco! Por exemplo, eu venho sempre fazer minha monografia aqui na UnB, e aí eu utilizo aqueles computadores dali do laboratório, só que desde do início do semestre tem só três computadores que tem internet, os outros todos, alguns nem ligar, ligam! Os outros não, os que ligam não têm internet, e tipo a sala já é pequena, já tem poucas máquinas e não é disponibilizado o serviço de uma forma.

PP7: Eu acho que é muito pouco ainda, a wifi daqui fica só caindo, e também a gente tinha um laboratório de informática pros alunos e hoje não tem mais, aí improvisaram alguns computadores por ali.

O participante da pesquisa PP5 faz uma crítica à disponibilidade de internet e computadores para os alunos poderem desenvolver seus trabalhos e cita uma sala de aula de informática que tem seu uso restrito. Uma das soluções para proporcionar o atendimento a uma maior quantidade de alunos estaria na melhor gestão dos espaços e infraestrutura. A utilização compartilhada de ambientes, salas e recursos poderia dar uma maior dinâmica ao segmento e melhorar a estrutura disponível para os acadêmicos. Sabe-se que em muitas ocasiões existe a preocupação com a depreciação dos equipamentos e ambientes, existindo alguns tipos de restrições para assegurar a prevenção, mas sempre existem soluções para melhor gestão do ambiente e recursos. No caso de laboratórios de informática, salas com equipamentos tecnológicos e afins, uma 
boa saída seria a utilização de monitores para manterem a ordem e organização do ambiente.

Gráfico 15 - Forma de Acesso ao Computador e Internet (Curso Presencial)

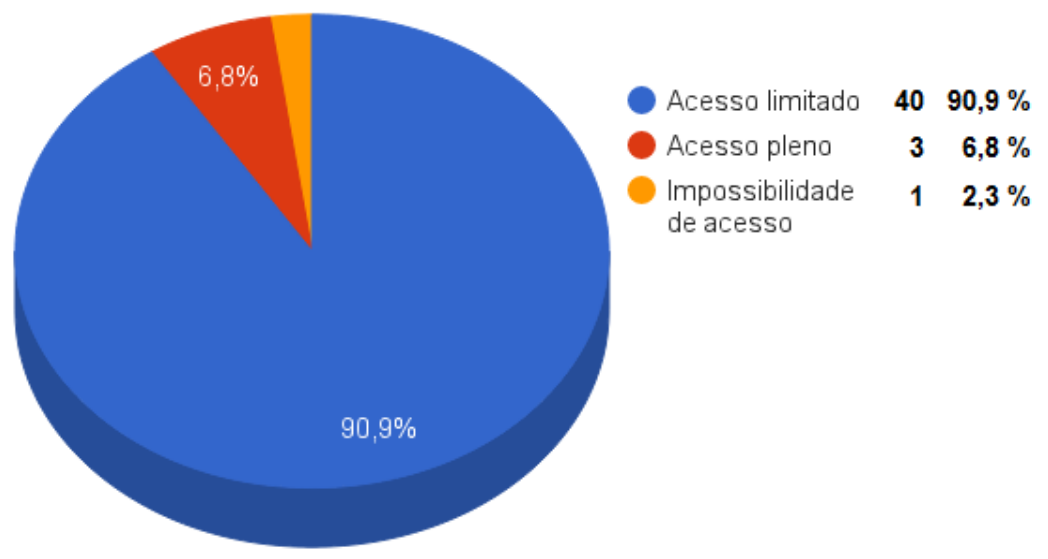

Em relação aos dispositivos tecnológicos e digitais disponibilizados na Faculdade de Educação, aproximadamente vinte e sete vírgula vinte e sete por cento $(27,27 \%)$ dos participantes, doze alunos (12), afirmaram que tiveram acesso ou utilizaram dispositivos tecnológicos (data-show, microfone, televisão, webcam, caixa de som, etc.) disponibilizados pela FE (Faculdade de Educação) em sua formação (Gráfico 16). Cerca de vinte e cinco por cento ( $25 \%$ ) dos participantes da pesquisa assinalaram que não tiveram acesso ou não utilizaram uma sala de multimídia ou videoconferência (Gráfico 17). Estas salas buscam tornar as aulas mais dinâmicas e interativas, proporcionando uma maior experiência com os equipamentos multimídia e interação on-line.

Gráfico 16 - Acesso aos Dispositivos Tecnológicos (Curso Presencial)

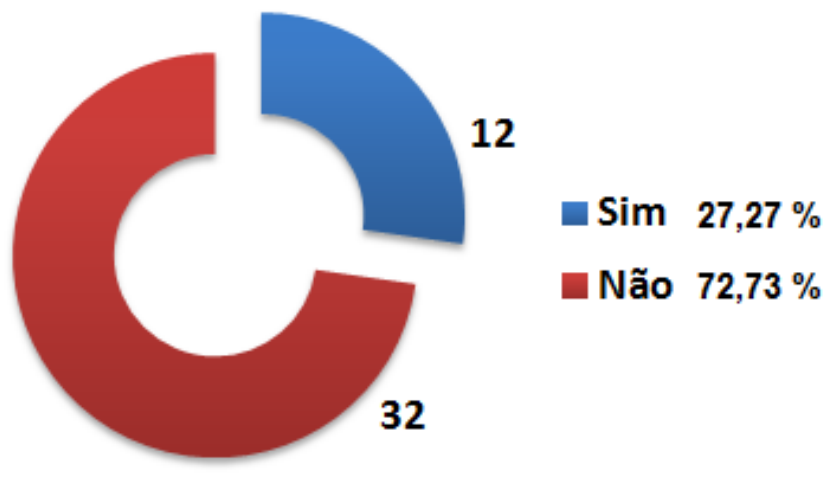


Gráfico 17 - Acesso à Sala de Multimídia ou Videoconferência (Curso Presencial)

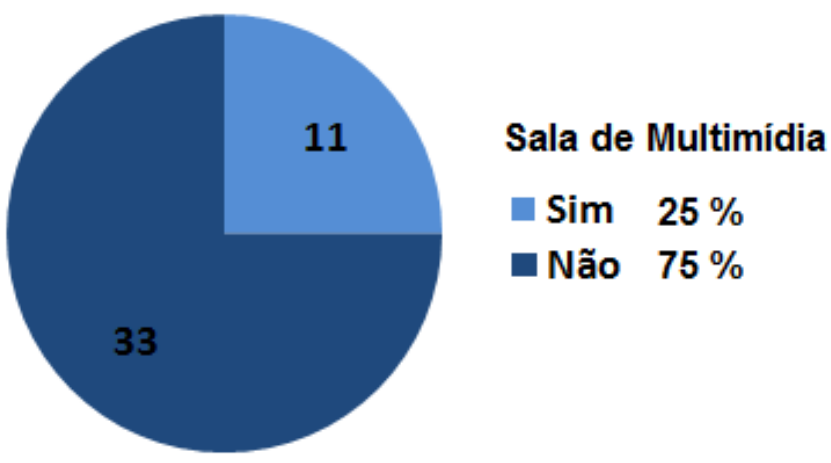

Quanto à disponibilidade oportunizada pela $\mathrm{FE}$ de equipamentos tecnológicos e digitais aos alunos, houve críticas em relação à quantidade de equipamentos, qualidade, forma de agendamento, etc. Trechos das entrevistas expressam a opinião dos participantes da pesquisa com a situação.

PP1: Webcam não (risos), data-show aqui na sala da FE5 tem em cada sala, mas não são todos que funciona... tem sala que ele fica todo vermelho, ou então ele fica todo verde, então a visualização às vezes atrapalha a gente. Quando vai apresentar um trabalho, a gente tem que sempre pensar nas cores do slide por conta disso, porque dependendo da cor que a gente usa no slide não vai ficar bom na iluminação do data-show [...].

PP2: Toda vez que precisa de um data-show você precisava agendar, nem sempre o mesmo tava disponível pro uso dos alunos. Tablet não é uma coisa que é oferecida né.

PP4: É, data-show às vezes funciona, às vezes num funciona [...].

PP7: Temos data-show e raramente uma caixa de som, e as caixas de som que tem ainda são ruins ainda.

PP6: Data-show sim, nós temos acesso, caixa de som eu não sei te informar, porque todas as vezes que eu precisei eu trouxe de casa, então eu acho que talvez nem tenha, uma vez a gente pegou uma emprestada daqui só que era bem baixinha nem dava pra ouvir direito, e das outras vezes eu trouxe de casa.

Os participantes da entrevista PP6, PP4, PP2 e PP1 ainda fazem ressalvas em relação à forma de agendamento e empréstimos dos equipamentos tecnológicos para serem utilizados na graduação.

PP1: Até onde eu saiba tem que agendar pela internet e aí no dia ir lá e fazer o pedido tudo mais, não é tão... assim tem uma emergência, e se precisar, você não vai conseguir. A não ser que seja aqui na FE5 porque 
tem dentro de sala, mas na FEl e na três não tem, aí tem que fazer o pedido.

PP4: [...] Eu particularmente faz tempo que eu não agendo, mas quando eu agendava era tranquilo, mas tem horário que você tem que ir, o público do noturno mesmo eu vejo que é bem difícil pra eles, quando tem greve você pode esquecer, então não é tão fácil.

PP6: Com relação, por exemplo, ao data-show, se você não reservar com uma semana de antecedência, vai chegar no dia da tua apresentação e não vai ter. Já passei por uma situação que eu reservei, chegou no dia da apresentação, todos estavam emprestados e o que estava reservado pra mim tava queimado e aí....

Percebe-se pelos Gráficos (Gráfico 16 e Gráfico 17) que a disseminação e disponibilização dos dispositivos tecnológicos e digitais na Faculdade de Educação ainda é incipiente. Nem um terço dos alunos pesquisados tiveram contato com tais dispositivos. A utilização desses dispositivos tecnológicos no ambiente educacional possibilita uma experiência mais rica dos alunos com o vídeo, o áudio, as imagens e os hipertextos dentro de sala de aula.

Quanto aos serviços on-line (informações, comprovantes, declarações, calendário, etc.), cerca de vinte e nove alunos (29), sessenta e cinco vírgula noventa por cento $(65,90 \%)$ dos participantes da pesquisa, responderam que os tiveram à sua disposição ou fizeram uso deste tipo de serviço (Gráfico 18).

Nota-se que boa parte dos alunos do curso presencial de Pedagogia já têm contato e utilizam dos serviços on-line para resolver problemas acadêmicos. Ressalta-se que ainda há muitos alunos que não estabeleceram acesso ou não sabem como fazê-lo, dentre os pesquisados. Atualmente é muito importante estar familiarizado com estes tipos de serviços. Vivenciamos uma época em que tudo está sendo digitalizado e sistematizado. Iniciativas como esta da FE em disponibilizar serviços de forma on-line crescem a cada dia. Inclusive várias instituições educacionais já trabalham com sistemas escolares on-line. Diários, notas, matrículas e todo tipo de serviço já pode ser desenvolvido pela internet. 
Gráfico 18 - Acesso aos Serviços On-line (Curso Presencial)

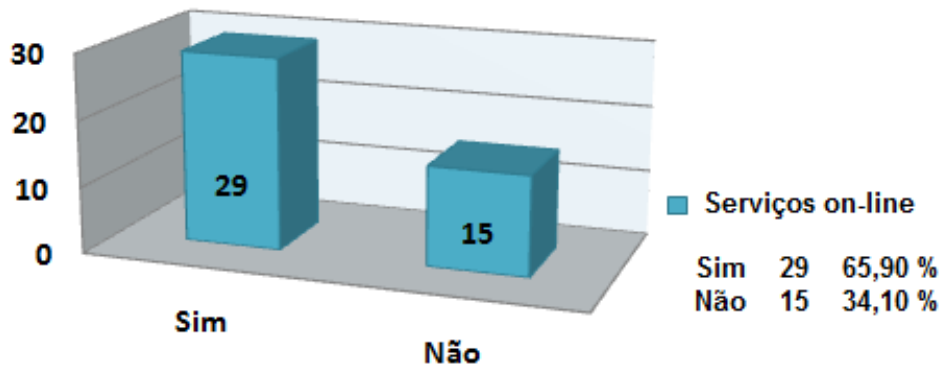

Em se tratando do estado de funcionamento dos equipamentos tecnológicos (computador, data-show, TV, etc.) utilizados durante a graduação, podemos observar pelo (Gráfico 19) que mais de oitenta e quatro por cento (84 \%) dos alunos julgam que os equipamentos tecnológicos se encontram desatualizados. As configurações físicas e lógicas estão ultrapassadas. Deixam os equipamentos com um desempenho e produtividade aquém do desejado. Para mais de cinquenta e dois por cento (52\%) dos alunos participantes, os equipamentos tecnológicos se encontram mal conservados. E apenas quatro vírgula cinco por cento $(4,5 \%)$ dos alunos responderam que entendiam que os equipamentos tecnológicos estavam atualizados e bem conservados.

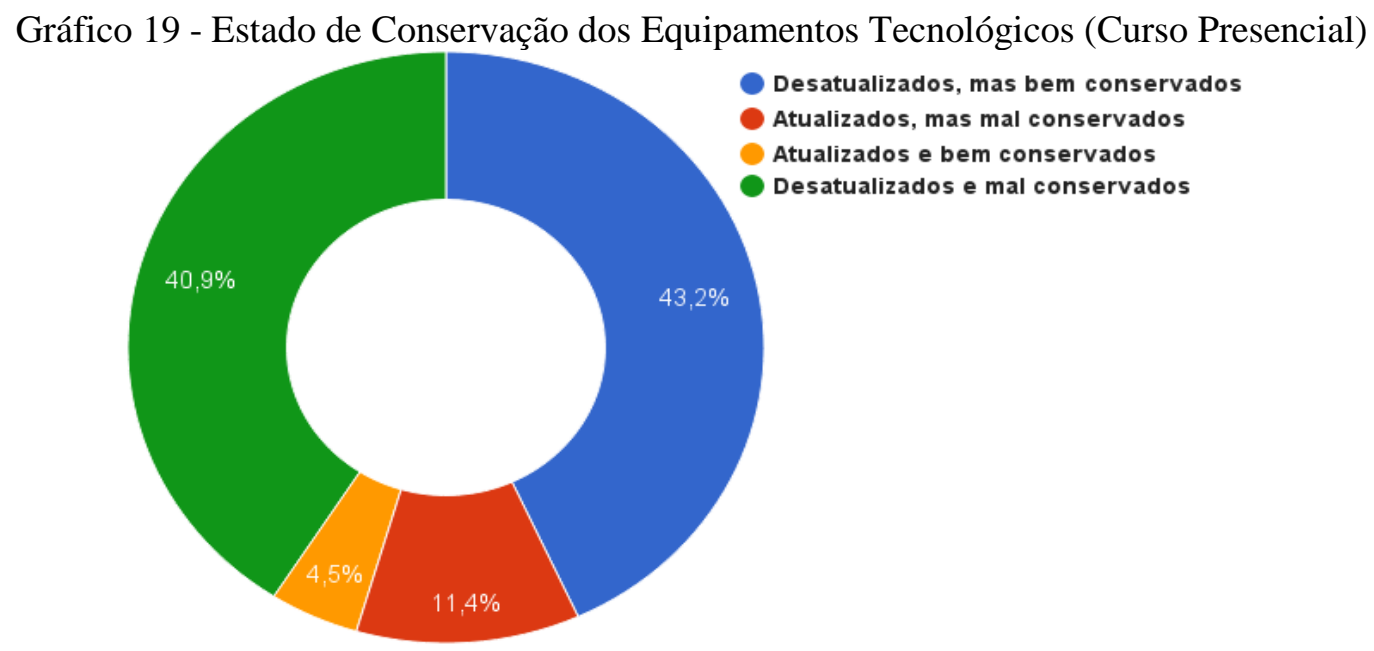

Percebe-se um descontentamento com os equipamentos tecnológicos que são disponibilizados para auxiliar os acadêmicos em suas atividades durante a graduação. Para ilustrar este cenário, algumas falas retiradas das entrevistas. 
PP1: Nossa, eu acho que deveriam dar uma olhada nos materiais pra renovar porque é muito difícil, caixa de som mesmo a gente não tem muitas, quando a gente precisa tem que trazer de casa nossa.

PP4: Cara, esses "computadores" do laboratório quando você olha parece que tá tudo bem, mas como eu te falei, vão parando de funcionar e ninguém vai arrumando.

PP5: [...] pelo menos os data-shows que eu tive mais acesso nas minhas aulas, quando não tá quebrado, assim tá funcionando bem.

PP7: [...] acho que esse suporte de informática assim é meio vago assim, não tem qualidade.

O participante da pesquisa PP7, assim como todos os outros, faz críticas à estrutura de física disponibilizada além de chamar a atenção para o suporte que é oferecido para essa estrutura. Uma forma de conseguir conservar o estado dos equipamentos e estrutura, além de prolongar a vida útil da infraestrutura tecnológica e digital, se trata de uma boa manutenção, que ainda garantirá uma maior quantidade de computadores à disposição dos alunos e uma melhor oferta dos serviços de internet. Sabe-se que a FE, assim como todas as instituições públicas, também passa por problemas relacionados com o contingente de servidores para suprir sua demanda de trabalho. Mais uma vez os monitores, estagiários poderiam ser de grande valia para melhoria do serviço prestado. Como avaliação geral da infraestrutura ofertada pela FE aos alunos do curso presencial do curso de Pedagogia, os entrevistados afirmaram o seguinte:

PP5: Deixa a desejar, poderia ser melhor. Eu acho assim... eu acho que tem possibilidade até economicamente!

PP2: É média, porque não deixa de não ter, mas o que tem não é suficiente pra fazer um uso bom assim, com qualidade, com qualidade pros alunos.

PP6: A manutenção dos aparelhos que tem aqui, não existe praticamente né. Uma sala mais adequada, que seja maior, que tenha mais espaços pras pessoas estudarem, dizem que tem uma sala ali na FE5 que tá pra ser... pra ser laboratório de informática, mas ali a FE5 tá em reforma desde de quando eu entrei aqui, ou bem antes... (risos), então não sei.

Quando analisamos a opinião dos alunos em relação à infraestrutura tecnológica e digital disponibilizadas aos alunos na graduação encontramos algumas diferenças em relação à modalidade de ensino devido às especificidades de cada uma. 
Existem diferenças entre as avaliações dos alunos que cursam Pedagogia a distância e de forma presencial. No tocante aos dispositivos tecnológicos e digitais (Gráfico 20), podemos perceber que setenta e dois vírgula sete por cento $(72,7 \%)$ dos alunos tiveram acesso ou utilizaram os computadores que foram disponibilizados nos polos para auxiliar os alunos em suas atividades acadêmicas.

Ainda pode ser notado que a internet não está sendo muito acessada dos polos, haja vista a quantidade elevada de participantes da pesquisa, doze alunos, o que equivale a quarenta e cinco vírgula cinco por cento $(45,5 \%)$, que afirmaram ter problema para acessar essa tecnologia ou não fazer uso dessa tecnologia no polo de estudo. Pelo fato de o curso ocorrer na modalidade a distância, vários tipos de serviços têm que ser realizados de forma remota. O que pode ser expresso pelos dados levantados junto aos alunos, dos quais sessenta e oito vírgula dois por cento $(68,2 \%)$ dos participantes afirmaram já ter utilizado o sistema on-line do curso para requerer algum tipo de serviço ou resolver algum problema.

Sobre os dispositivos tecnológicos e digitais, dez alunos (10), cerca de quarenta e cinco vírgula cinco por cento $(45,5 \%)$ dos participantes, indicaram que tiveram acesso ou utilizaram tais dispositivos. E cerca de sessenta e três por cento $(63,6 \%)$ dos alunos participantes da pesquisa assinalaram que tiveram acesso ou usufruíram de uma sala de multimídia ou videoconferência.

Gráfico 20 - Acesso aos Dispositivos Tecnológicos e Digitais (EAD)

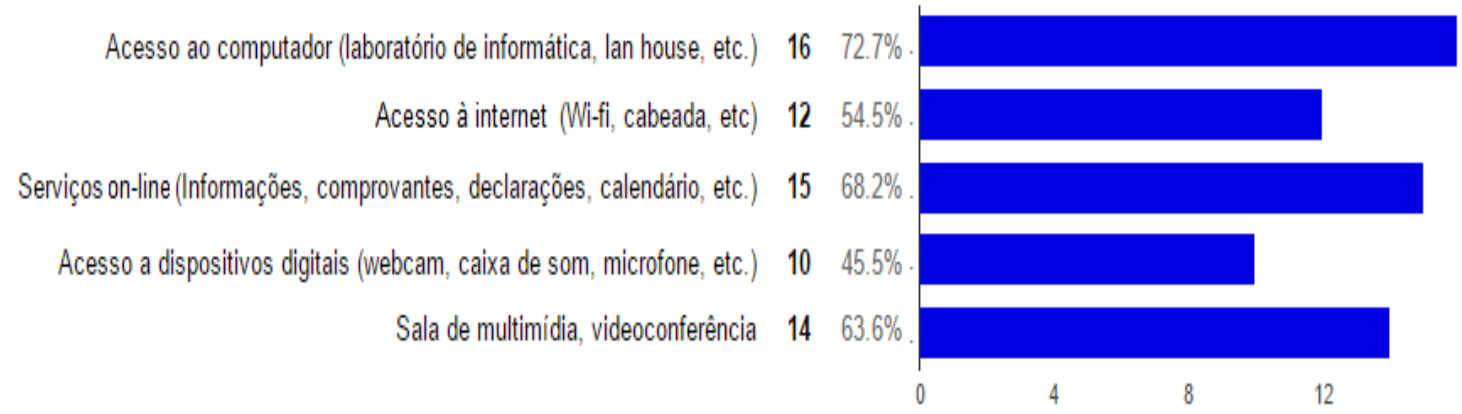

Percebe-se que a porcentagem de participantes que assinalaram ter acesso ou que utilizam os computadores e internet disponibilizados para os estudos foi bem diferente em relação à modalidade de ensino presencial. A porcentagem de utilização e acesso por parte dos alunos que estudam na EAD foi menor em relação aos alunos da 
modalidade presencial. Dado que pode ser explicado pelo fato de vários alunos já possuírem computadores em suas residências ou residirem longe dos polos e também pelo fato de os polos de estudo possuírem uma conexão de internet muito lenta.

Foi feita a pergunta aos entrevistados PP8, PP9 e PP10: Vocês têm acesso a data-show, caixa de som, equipamentos multimídia? E eles responderam de uma forma geral que eles tinham acesso a estes dispositivos tecnológicos, que os computadores eram bons. Uma crítica foi feita (PP10) em relação ao ambiente do polo que estaria deixando a desejar com relação às suas acomodações.

PP8: Eu acho que precisa ter, porque as tutoras de polo elas vivem escaneando algumas coisas e mandando pra gente. Eu acho que tem, a estrutura, não sei pra... o que eu reparei lá foi estrutura física do local mesmo, mais questão de banheiro e tudo, mas computador eu acho que também, essa parte.

PP9: [...] existe um laboratório muito interessante lá, tem todos os recursos de mídia que você pode imaginar com data-show, com os laptops, projetores, caixas de som pra poder fazer apresentações, resumindo: todos os recursos que eram necessários pra se utilizar na formação tava disponível.

PP10: Tem, a gente tem tudo isso sim! Assim, o prédio em si deixa a desejar mas a questão dos computadores são bons.

O participante da pesquisa PP8, aluno de Pedagogia na modalidade EAD, ilustra bem a situação dos alunos que residem longe do polo e preferem desenvolver suas atividades onde residem. O trecho retirado da entrevista com ele expressa tal situação quando ele relata que não usa os computadores e internet do polo de estudo.

PP8: [...] eu uso em casa. Eu raramente vou no polo, só quando tem aula, e o encontro presencial não tem jeito de não ir, porque pra mim essa parte de deslocar pro polo é mais difícil.

O participante da pesquisa PP9 fez uma crítica à conexão com a internet disponibilizada para os alunos fazerem seus trabalhos e também ser utilizada nas aulas e videoconferências. $\mathrm{O}$ entrevistado também relata as dificuldades relacionadas à 
qualidade e à tecnologia empregada na conexão de internet e sua relação com a localização do polo de estudo.

PP9: Olha só, lá no polo onde a gente é atendido existe toda a estrutura, porém a captação do sinal ela deixa a desejar em determinados momentos, então por exemplo, eles têm lá, eu não sei qual é o link que tá disponível pra eles né, mas no meu entendimento poderia ser feito um investimento maior pra ter um link direto via satélite com a Anatel pra poder tá atendendo essa demanda, porque o local onde se encontra a escola é uma zona rural, então provavelmente é via rádio a transmissão do sistema, isso dificulta a determinados procedimentos.

PP9: [...] conferências que a gente organizou ficou prejudicada por causa disso, entendeu?! Então, por exemplo, eu conseguia muito bem captar o sinal de determinado polo que estava participando da conferência, mas outros já não me ouviam, isso acontecia tipo assim, eu tava em Alexânia, o pessoal de Brasília não conseguia me enxergar, entendeu? Mas eu conseguia enxergar o pessoal de Goiás, que é uma outra cidade no estado de Goiás, entendeu?!

Vários alunos preferem estudar em casa onde possuem melhor conexão com a internet para desenvolver suas atividades. O Gráfico 21 expressa estes dados: metade dos alunos, onze alunos (11), participantes da pesquisa que estudam na modalidade EAD, apontaram que possuem um acesso limitado à internet e aos computadores.

PP9: [...] por demandas de local, da posição geográfica, ficou penalizado em determinados momentos, não que isso seja uma realidade que prejudicou o andamento não, não é isso! Nós, como é pontual né, por acaso eu estou em Brasília, eu não estou em Alexânia, eu não sofri esse tipo de transtorno. Eu tô com 15 megas aqui que funciona muito bem, mas é privado, é particular.

Gráfico 21 - Forma de Acesso aos Computadores e Internet no Polo de Estudo (EAD)

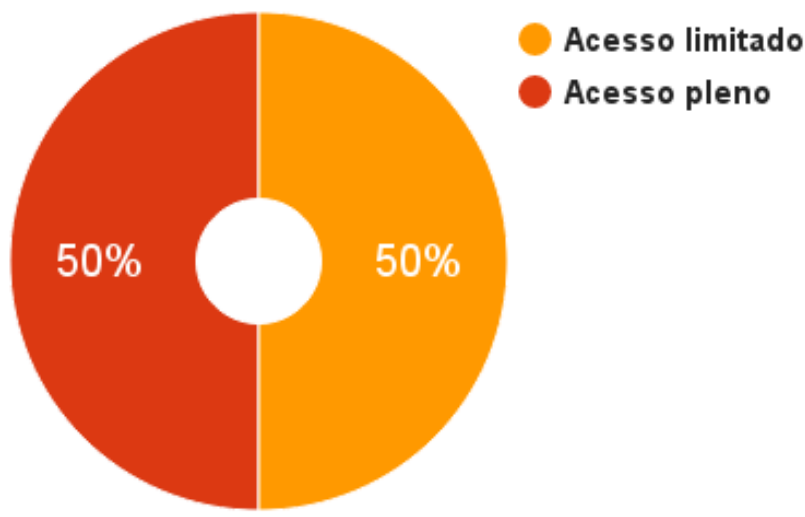


Quanto às condições, em geral, de funcionamento dos equipamentos tecnológicos (computador, data-show, TV, etc.) utilizados durante a graduação no polo de estudo, para mais de sessenta e três por cento $(63 \%)$ dos participantes da pesquisa os equipamentos tecnológicos se encontravam atualizados. Confirmando o bom estado de funcionamento dos equipamentos, cerca de setenta e sete por cento $(77 \%)$ dos alunos afirmaram que os equipamentos se encontravam em bom estado de conservação. Apenas nove vírgula um por cento $(9,1 \%)$ dos participantes assinalaram que os equipamentos tecnológicos se apresentavam desatualizados e mal conservados (Gráfico 22).

Gráfico 22 - Condição de Funcionamento dos Equipamentos Tecnológicos

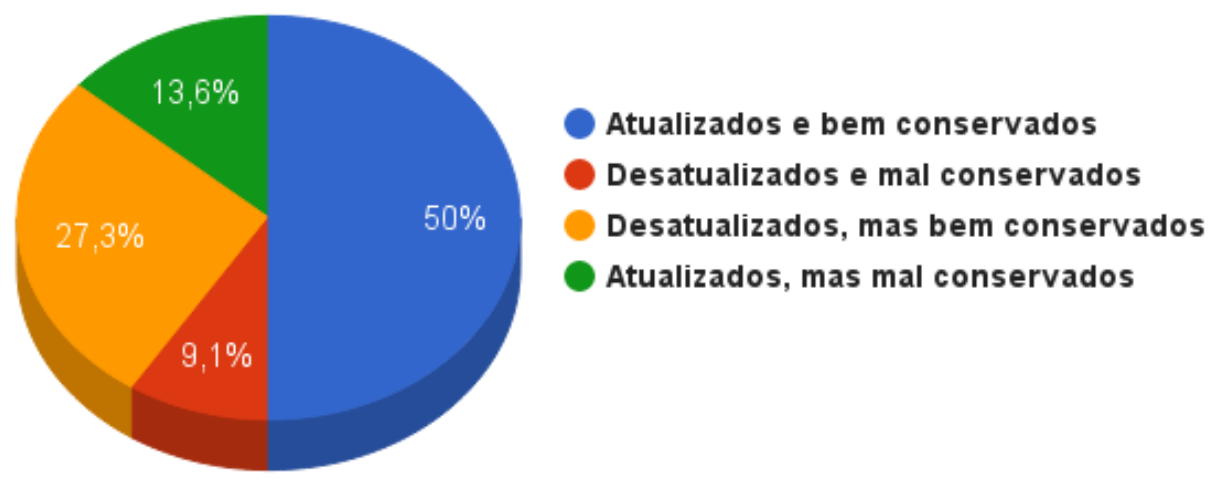

Percebemos que os polos dos formandos que participaram da pesquisa, (Alexânia-GO e Goiás Velho-GO), possuem uma boa infraestrutura de equipamentos tecnológicos e digitais, com a ressalva para o acesso à internet que apresenta problemas pelo fato de o link ser lento e instável. O participante PP10 deixa clara esta situação em um trecho retirado da entrevista.

PP10: [...] apesar de que a gente ainda tem um polo que às vezes né, por ser de interior, a internet nem sempre tá funcionando né, mas pelo menos assim, os computadores estavam adequados né. Bem conservados, a gente ganhou computadores novos, então assim, a questão é da reclamação, como, por ser interior né, às vezes a internet fica falhando, mas não a questão da conservação dos computadores não, foram ótimos né! O polo deu muito apoio.

O entrevistado PP5 faz um relato sobre a importância de se ter a infraestrutura tecnológica e digital à disposição dos alunos na graduação para melhor desenvolvimento no curso. 
PP5: Por exemplo, eu não tenho computador/notebook que eu possa levar pra casa. Então assim, eu acho que esse tipo de coisa interfere na nossa formação de uma forma que se a gente tivesse condições melhores de uso de tecnologia, eu acho que os nossos trabalhos seriam mais bem feitos né.

Observa-se que a Faculdade de Educação disponibiliza aos seus alunos como suporte ao curso de Pedagogia diversos dispositivos e ferramentas tecnológicas. Pode-se perceber, pelos dados coletados, que a FE oportuniza aos seus alunos o acesso a computadores, internet e dispositivos tecnológicos que podem ser utilizados pelos alunos para realização de atividades curriculares e também em aulas. Vale ressaltar que essa infraestrutura ofertada sofreu muitas críticas, principalmente pelos alunos do curso presencial.

Quanto aos computadores, a quantidade, a conservação, a atualização e o ambiente foram questionados. Quanto à internet, a qualidade do acesso (link lento), o alcance do link que não funcionava em todos os prédios. Quanto aos dispositivos tecnológicos e digitais, quantidade disponível para utilização, estado de conservação e condição de agendamento. Percebe-se então que a FE vem disponibilizando uma infraestrutura que, na opinião dos alunos participantes da pesquisa, ainda precisa ser melhorada para um melhor aproveitamento e suporte aos graduandos no curso.

\subsection{O Currículo do Curso de Pedagogia e as TDICE}

Além da disponibilização de uma infraestrutura tecnológica para familiarização dos futuros professores com as mudanças advindas do avanço científico e tecnológico em nossa sociedade, se faz de muita importância que o currículo do curso de Pedagogia proporcione oportunidades de levar ao seu aluno conhecimentos e práticas que lhe

possibilitem estar incluído digitalmente. A globalização e sistematização vêm trazendo muitas mudanças em nossa forma de agir, trabalhar, estudar, nos divertirmos, etc. $\mathrm{O}$ currículo escolar tem que refletir e contemplar essas mudanças que acontecem em nossa sociedade com conhecimentos que possibilitem aos seus alunos estarem atualizados e inseridos em um contexto no qual tenham intimidade, conhecimento e autonomia para desenvolverem seu trabalho. 
Moran (2013, p. 53) ressalta que a educação escolar precisa compreender e incorporar mais as novas linguagens, desvendar os seus códigos, dominar as possibilidades de expressão e as possíveis manipulações. O autor relata que é importante educar para usos democráticos, mais progressistas e participativos das tecnologias, que facilitem a evolução dos indivíduos. Ele chama atenção para a forma como a educação se comporta em relação às mudanças que ocorrem em nossa sociedade. Para Moran (2013, p. 12), a escola precisa reaprender a ser uma organização efetivamente significativa, inovadora, empreendedora. Ela é previsível demais, burocrática demais, pouco estimulante para os bons professores e alunos. Não há receitas fáceis nem medidas simples. Mas essa escola está envelhecida em seus métodos, procedimentos, currículos. O autor observa que

Enquanto a sociedade muda e experimenta desafios mais complexos, a educação formal continua, de maneira geral, organizada de modo previsível, repetitivo, burocrático, pouco atraente. Apesar de teorias avançadas, predomina, na prática, uma visão conservadora, repetindo o que está consolidado, o que não oferece risco nem grandes tensões (MORAN, 2013, p. 12).

Várias mudanças precisam ser feitas para adequação da formação ofertada e do currículo de uma escola para sua atualização e conformação com a sociedade informacional. Nunes (2012, p. 45) ressalta que as instituições formadoras de nível superior precisam, além de inclusão de disciplinas e conteúdos sobre o uso das TICs em seus currículos das licenciaturas, incluindo a Pedagogia, oferecer instalações físicas e recursos humanos e materiais adequados a uma formação científica e tecnológica do futuro professor. Kenski (2012, p. 106) ainda observa que

\footnotetext{
A formação de qualidade dos docentes deve ser vista em um amplo quadro de complementação às tradicionais disciplinas pedagógicas e que inclui, entre outros, um razoável conhecimento de uso do computador, das redes e de demais suportes midiáticos (rádio, televisão, vídeo, por exemplo) em variadas e diferenciadas atividades de aprendizagem.
}

Para a autora, as tecnologias exigem transformações não apenas nas teorias educacionais, mas na própria ação educativa e na forma como a escola e toda a sociedade percebem sua função na atualidade. As mais modernas tecnologias de 
informação e comunicação exigem uma reestruturação ampla dos objetivos de ensino e aprendizagem e, principalmente, do sistema escolar (KENSKI, 2012, p. 101-102).

Foi feita uma pesquisa com os alunos do curso de Pedagogia nas modalidades presencial e a distância da UNB acerca da opinião deles em relação às possibilidades curriculares oportunizadas pela Faculdade de Educação a eles para sua inclusão digital e formação para uma docência mediada pelas TDICE. Aqui foram analisadas quais opções curriculares foram ofertadas aos alunos para sua inclusão digital (disciplinas, teoria, práticas, oficinas, etc.).

Foi perguntado aos alunos participantes da pesquisa, por meio do questionário, se a formação ofertada pelo curso de Pedagogia da UNB tinha proporcionado a sua formação para trabalharem com as TDICE enquanto futuros professores. Nota-se, pelo Gráfico 23, que cinquenta por cento (50\%) dos alunos, vinte e dois (22), que cursam Pedagogia presencialmente, assinalaram que por meio de disciplinas do curso tiveram conhecimento sobre as TDICE na educação. Cerca de quarenta e sete vírgula sete por cento $(47,7 \%)$ dos participantes afirmaram que não tiveram uma formação que lhes proporcionasse trabalhar com as TDICE. Apenas dois vírgula três por cento $(2,3 \%)$ dos participantes afirmaram que se sentiram preparados para trabalharem com as TDICE por meio de oficinas ofertadas na graduação.

Gráfico 23 - Formação para Trabalhar com as TDICE (Presencial)

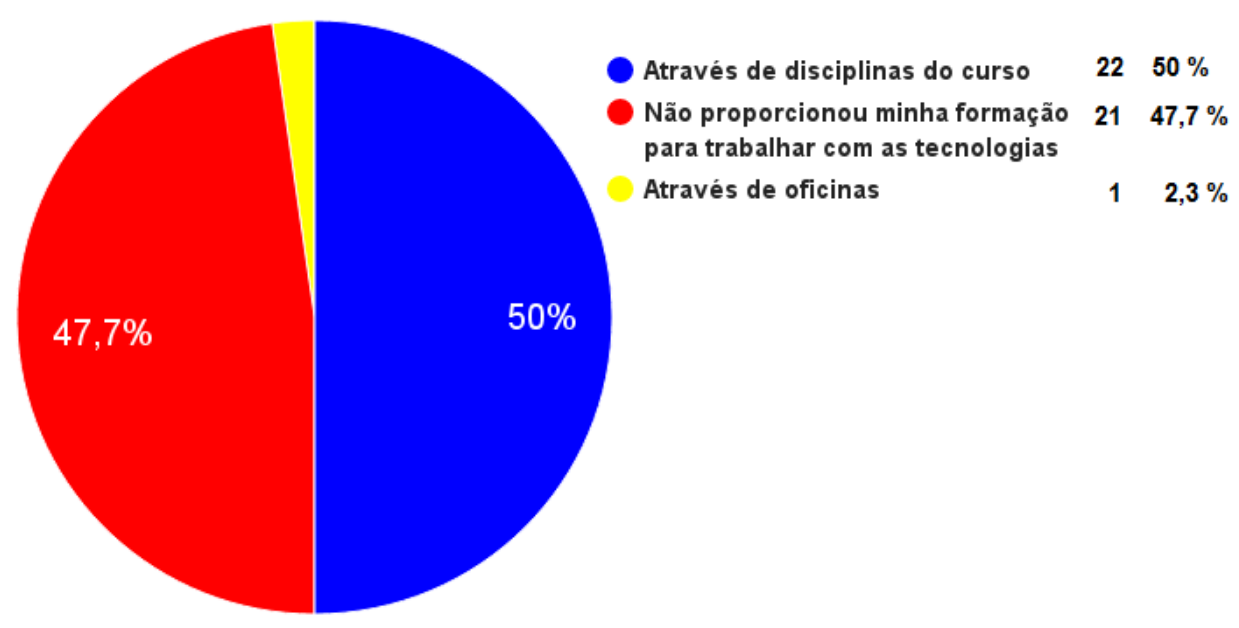

Em relação aos alunos da modalidade a distância, o Gráfico 24 ilustra que eles apontaram que tiveram maiores possibilidades curriculares de terem contato com conhecimentos relacionados às TDICE. Cerca de sessenta e três vírgula quatro por cento 
$(63,4 \%)$ dos participantes da pesquisa, quatorze alunos, assinalaram que tiveram contato com conhecimentos sobre as TDICE em sua formação. Quarenta e cinco vírgula cinco por cento $(45,5 \%)$ dos participantes indicaram que este contato aconteceu por meio de disciplinas do curso. Para treze vírgula seis por cento (13,6\%) dos participantes, os tutores contribuíram em sua formação para que aprendessem como trabalhar com as TDICE. Para oito participantes da pesquisa, trinta e seis vírgula quatro por cento $(36,4 \%)$ dos alunos, a formação que tiveram não lhes proporcionou ter conhecimentos para trabalharem com as TDICE enquanto professores.

Gráfico 24 - Formação para trabalhar com as TDICE (EAD)

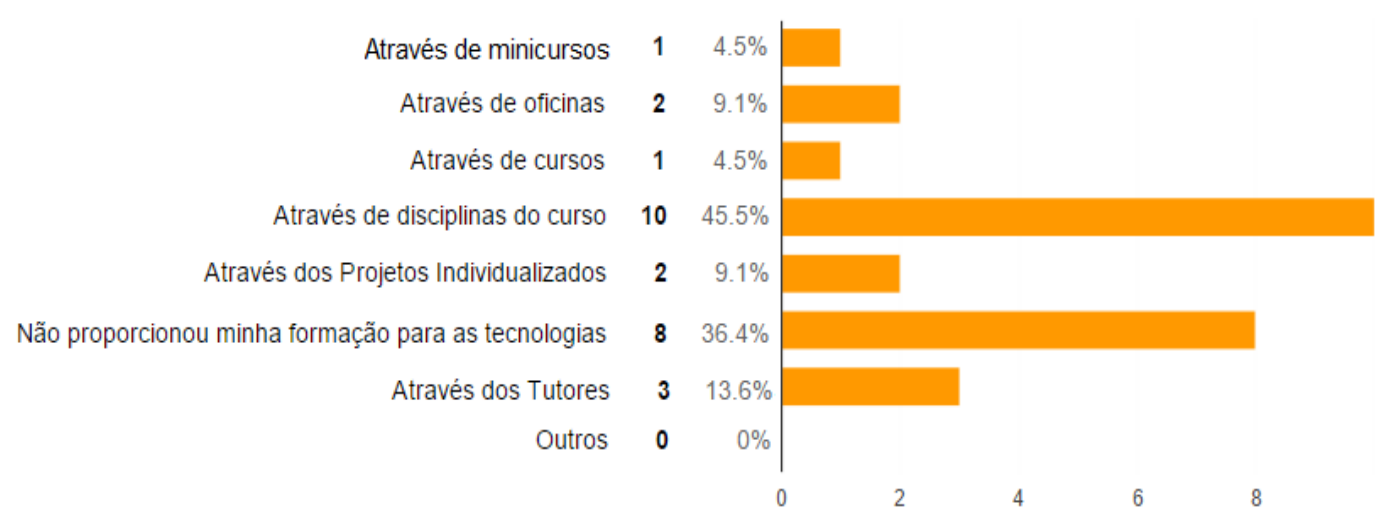

Em se tratando das disciplinas que versavam sobre a teoria da temática (Educação e Tecnologias), ofertadas no curso presencial de Pedagogia (Gráfico 25), doze alunos, o que corresponde a vinte e sete vírgula vinte e sete por cento $(27,27 \%)$ dos participantes assinalaram que não cursaram disciplinas que tratavam dessa temática. Lembrando a flexibilidade curricular que o curso de Pedagogia na modalidade presencial dispõe, o aluno tem a liberdade de escolher as disciplinas optativas que gostaria de cursar. Mais de setenta e dois por cento (72\%) dos participantes afirmaram ter cursado alguma disciplina que tratava da temática (Educação e Tecnologias). Destes, trinta e oito vírgula sessenta e três por cento $(38,63 \%)$ dos participantes indicaram que tiveram acesso a essa temática em disciplinas obrigatórias do currículo e trinta e quatro vírgula um por cento $(34,1 \%)$ indicaram que o acesso foi por meio de disciplinas optativas. 
Gráfico 25 - Disciplina sobre a Teoria da Temática Educação e Tecnologias (Presencial)

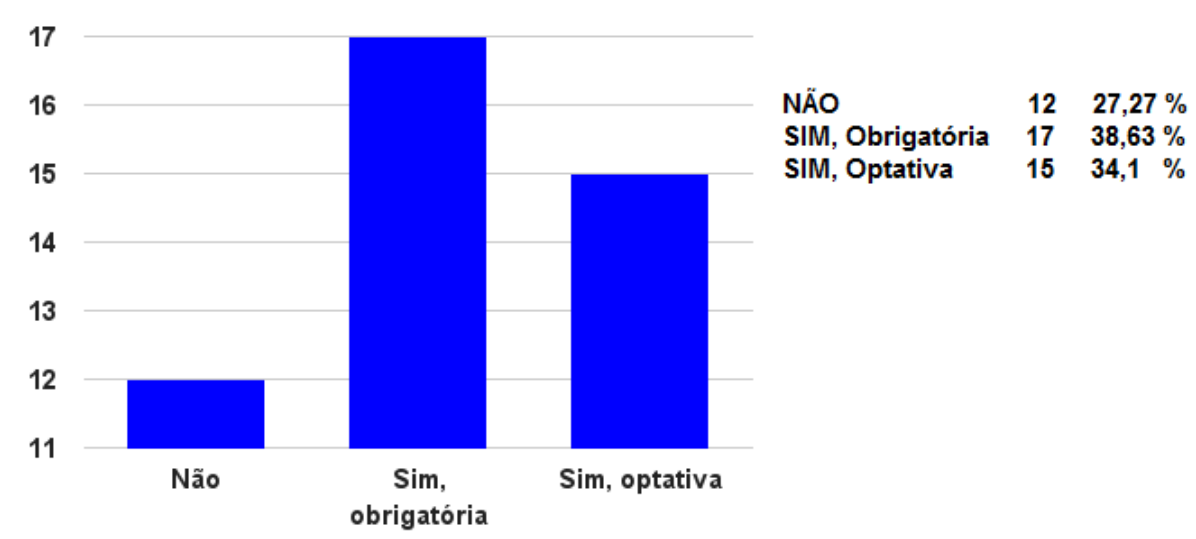

O entrevistado PP1, ao ser questionado, disse que sentiu falta da teoria que abordava a temática envolvendo as tecnologias e educação e relatou:

PP1: Sim, com certeza que isso realmente não tratou nada, eu não sei na outra disciplina que tem porque eu não cursei, mas nessa mesmo num tratou de nada disso.

Em outras falas dos entrevistados em relação às disciplinas curriculares ofertadas no curso, os trechos retirados das entrevistas ilustram a opinião dos participantes. Os entrevistados PP1 e PP2 relatam que fizeram algumas disciplinas que tratavam da temática (Educação e Tecnologias) mas que não se sentiram preparados para planejamento e utilização das tecnologias em sala de aula. O entrevistado PP2 demonstrou sua preocupação em obter tais ensinamentos quando relata que buscou cursos externos para poder utilizar em sua prática docente.

PP1: A gente tem uma disciplina eu acho, se não me engano de mídias digitais especificamente, mas é uma disciplina optativa. Eu peguei, na verdade são duas, eu peguei prática de mídias midiáticas, mas eu falo assim com formação de professor pra eu utilizar aquilo em sala de aula não me ajudou em nada, porque o professor ensinou assim: a fazer blog, a mexer em blog e eu acho que isso em sala de aula pra mim não é nem um pouco interessante porque eu não vou montar um blog com as crianças, talvez monte mas... num....

PP2: Oh vou ser muito sincera, eu sei de uma disciplina que trabalha Práticas Midiáticas na Educação, que trabalha assim com o uso de computador, uso de mídia, e ela é optativa. Então, o que eu sei do uso e do planejamento do uso dessas tecnologias, eu aprendi por meio de cursos externos, de demanda minha própria e de um entendimento que eu tinha que era necessário que eu aprendesse como fazer o uso disso dentro da minha prática docente. 
O participante PP5 relata que fez duas disciplinas, mas, segundo o entrevistado, em uma o conteúdo não tinha nada a ver com tecnologias (ensino de ciência e tecnologia) e a outra (mídias) ele trancou pelo fato de não ter infraestrutura adequada para o desenvolvimento das aulas. Já o entrevistado PP7 relatou que fez duas disciplinas e gostou muito, e ele fez ressalva em relação ao aprofundamento do conteúdo que foi trabalhado.

PP5: Eu fiz uma disciplina que era ensino de ciência e tecnologia, e num tive nada sobre tecnologia nela, eu fui fazer a disciplina até achando que era totalmente nessa... ia me incluir assim geral, eu ia saber de tudo e num sei o que, na verdade eu só estudei ciências naturais, ao meu ver não tinha nada de tecnologia assim. Não me lembro de outra disciplina que tivesse a ver. Tem uma de mídias, mas os computadores também não funcionam, a gente tinha que ficar dividindo, até tranquei a matéria por conta disso, porque não funciona, não rolava, tinha que trazer computador de casa, e ficava com medo de andar aqui na faculdade com computador, então acabei até trancando a disciplina.

PP7: Eu fiz uma disciplina aqui, eu fiz duas na verdade, uma sobre mídia e uma sobre tecnologia mesmo, aí na faculdade, gostei bastante, mas não foi muito aprofundado não, era duas matérias optativas e aí que no caso ficou muito superficial, eu achei que deveria aprofundar mais.

Em relação aos alunos do curso a distância de Pedagogia, obtivemos dados similares (Gráfico 26). Cerca de setenta e sete vírgula três por cento (77,3\%) dos alunos, dezessete acadêmicos, afirmaram ter cursado alguma disciplina que retratava a temática (Educação e Tecnologias). E quatro alunos, o que representa dezoito vírgula dois por cento $(18,2 \%)$ dos participantes, assinalaram que não tiveram disciplinas que abordassem a temática citada. Um aluno não soube responder.

Gráfico 26 - Disciplina sobre a Teoria da Temática Educação e Tecnologias (EAD)

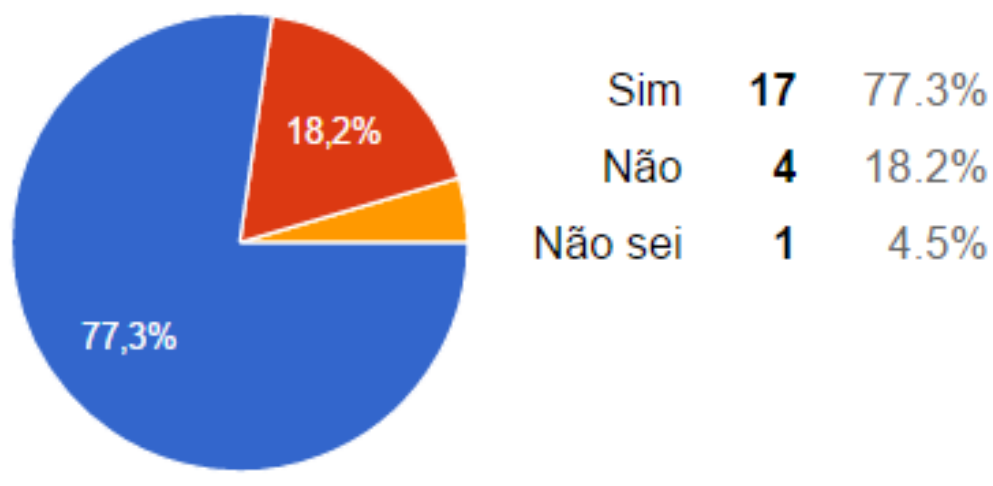


Quanto à prática envolvendo as TDICE na educação, quarenta e três vírgula dezoito por cento $(43,18 \%)$ dos alunos do curso presencial assinalaram que não cursaram nenhuma disciplina que proporcionava ensinamentos de como proceder na prática com as tecnologias na escola (Gráfico 27). Cerca de cinquenta e seis por cento $(56 \%)$ dos participantes afirmaram ter cursado disciplinas que tratavam da prática com as tecnologias na educação. Destes, quarenta e três vírgula dezoito por cento $(43,18 \%)$ afirmaram que a disciplina cursada era optativa e treze vírgula sessenta e quatro por cento $(13,64 \%)$ dos participantes indicaram que a disciplina cursada era obrigatória.

O entrevistado PP10 descreve sua experiência com uma disciplina teórica que aborda o tema das tecnologias na educação e inclusão digital. Percebe-se por sua fala que, apesar de ter tido tal disciplina, ele relata que não teve aprofundamento, viu de forma superficial.

PP10: A gente estudou muito pouco sim! Uma disciplina educação a distância, a gente teve algum contato sobre a inclusão digital, não específico mas a gente teve né, alguns trabalhos assim relacionados a esse tema não por aprofundamento maior.

Gráfico 27 - Disciplina sobre a Prática da Temática Educação e Tecnologias (Presencial)

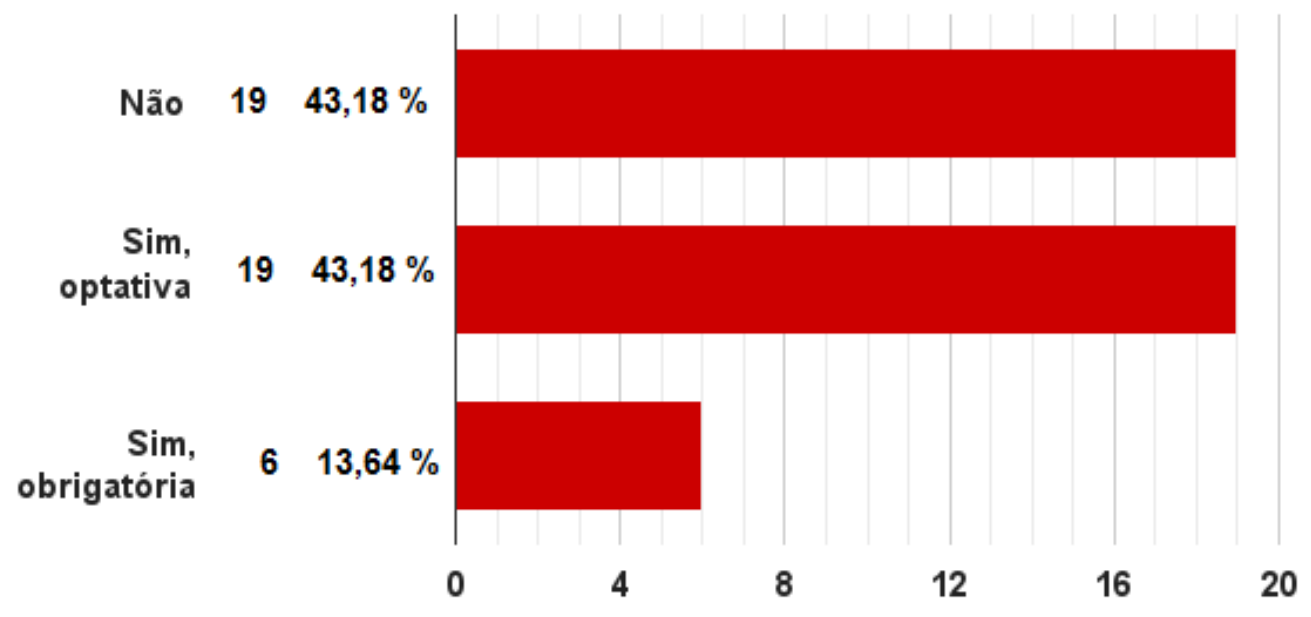

Em relação a ter cursado disciplinas que versavam sobre a prática envolvendo as TDICE, os entrevistados PP1 e PP5 relatam que não tiveram experiência curricular com disciplinas que trabalhassem a prática com as TDICE. 
PP1: Não, nem nessa disciplina que eu fiz a gente teve isso.

PP5: Na minha formação eu não tive, e eu tô formando. Não sei se outras pessoas tiveram com outras disciplinas, mas com os professores que eu peguei essas matérias não. Eu acho importante, acho que a gente fica melhor preparado, a gente que tem mais prática no nosso curso né.

O entrevistado PP2 relata que não teve este tipo de ensinamento. O participante afirma que teve, sim, disciplina na qual aprendiam a utilizar o Moodle (Ambiente Virtual de Aprendizagem), mas era uma utilização somente como aluno e de forma limitada. Não saberia implementar em sala de aula com seus alunos. O aluno faz a sugestão de implementação de alguma atividade que possibilite aos alunos trabalharem com as mídias para poder utilizá-las dentro e fora da faculdade.

PP2: Aqui dentro da faculdade eu não fiz nada que fosse ligado a isso, o que a gente aprender de tecnologia é aprender a usar o Moodle, mas é usado como aluno, não aprender como montar por exemplo, uma matéria dentro do Moodle, eu nunca aprendi como inserir sei lá biblioteca dentro do Moodle, eu nunca aprendi esse tipo de coisa, aprendi a usar como aluno mesmo, foi deficiente assim.

PP2: Eu acredito que nessa primeira parte do currículo caberia, por exemplo, algo que lidasse com uso de mídias, algo que trabalhasse o uso dessas mídias, das mais diversas mídias dentro da educação, não só no sentido da prática docente, mas na prática do aluno, que dê condições de montar um seminário, quantas vezes você não tem que montar, ah sei lá, você é monitor ajudar na disciplina. Desse tipo de ferramenta que é usado aqui dentro e fora daqui.

O entrevistado PP3 relata que cursou disciplinas que tratavam das tecnologias na educação, mas devido às fragilidades de estrutura o desenvolvimento das aulas ficou comprometido.

PP3: No currículo tem entre três disciplinas né, inclusive eu já fiz, mas que são optativas: computadores na educação, tem oficinas de audiovisual, tem o cinema em educação, acho que tem mais umas duas aí... Mas é aquela coisa, não tem estrutura, a qualidade das disciplinas também são comprometidas eu acho.

O entrevistado PP4 relata que optou por fazer a disciplina que abordava o tema inclusão digital vislumbrando a importância que aqueles conhecimentos teriam para sua 
formação. Ele afirma ter gostado da disciplina e ter aprendido muitas coisas que poderão ser aplicados em sua prática com os alunos.

PP4: Sim, eu tive uma disciplina, mas todas são optativas, essas disciplinas que trabalham com a inclusão digital e optei por fazê-la porque eu achei interessante, porque era a disciplina em si, ensinava fazer vídeos. E eu achei interessante, porque eu acho que o professor ele tendo uma formação mais completa sobre isso ele pode disponibilizar isso e ensinar para os seus alunos né, mesmo com pouco... mesmo deixando a desejar essas tecnologias nas escolas. Mas eu gostei bastante da disciplina, eu aprendi a fazer.

Em relação aos alunos do curso a distância, cinquenta por cento (50 \%) assinalaram que não cursaram nenhuma disciplina que proporcionava ensinamentos de como proceder na prática com as tecnologias na escola (Gráfico 28). Cerca de quarenta e cinco vírgula cinco por cento $(45,5 \%)$ dos participantes afirmaram ter cursado disciplina(s) que proviam ensinamentos sobre a prática docente com as TDICE. Um aluno não soube responder.

Gráfico 28 - Disciplina sobre a Prática da Temática Educação e Tecnologias (EAD)

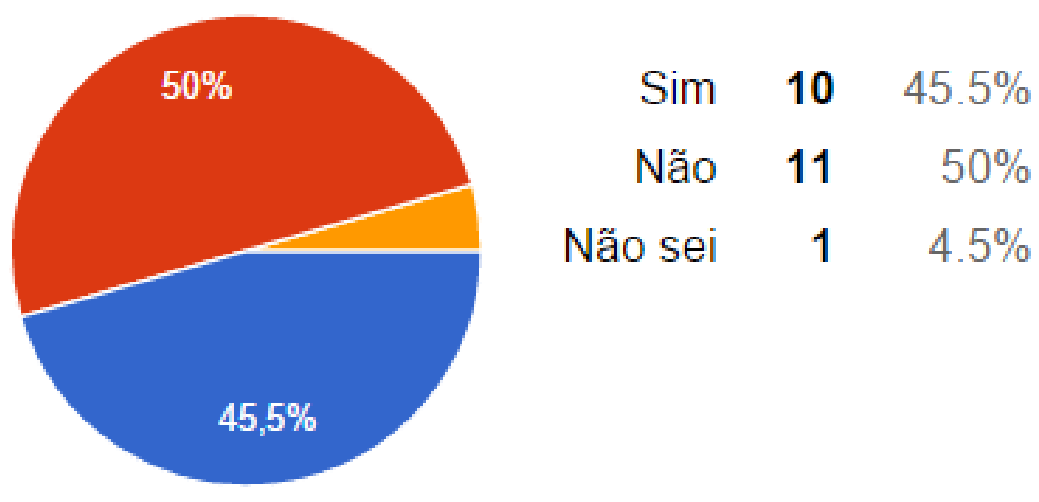

O entrevistado PP8, ao ser indagado sobre disciplinas que abordassem práticas com as tecnologias na sala de aula, responde:

PP8: Nos últimos dois semestres, eu tô vendo mais tutorial a respeito no ambiente tem algumas coisas, cursos pra aprender a mexer com ferramenta, no começo do curso não tinha não. Mas agora tá tendo, eu tenho visto isso. 
Foi perguntado aos entrevistados PP9 e PP10 se eles tiveram alguma disciplina que lhes ensinaram a trabalhar com as tecnologias no dia a dia dentro da sala de aula. Eles responderam:

PP9: Não, não há uma preocupação neste sentido não. Não teve essa preocupação, mostrar a tecnologia e dizer como é que você vai usar não!

PP10: Não, isso não. Não me lembro de ter sido abordado esse tema com a gente não. Nós fomos bastante pra sala de aula, mas não tratamos dessa questão.

Percebe-se que um grande contingente de alunos, quase cinquenta por cento (50\%) de todos os participantes da pesquisa, afirmaram não ter cursado disciplinas que proporcionassem conhecimentos relacionados com a prática docente com dispositivos tecnológicos. Dado que é muito preocupante, já que o aluno, ao ir exercer a docência, se deparará com diversas situações nas quais sua formação inicial daria suporte às atividades que deverão ser desenvolvidas. Uma formação que não contemple aspectos relacionados com a inclusão digital do aluno estará defasada em relação ao que se passa fora da escola. O resultado será uma grande dificuldade que os futuros professores terão para adaptar-se a uma prática e lógica para as quais não foram preparados.

Foi perguntado aos participantes da pesquisa se eles acreditavam ser necessário ter disciplina que trate das novas tecnologias e sua relação com a educação na graduação. Os alunos do curso presencial, em sua maioria, noventa vírgula nove por cento $(90,9 \%)$, afirmaram ser necessário ter disciplinas que tratem deste assunto. Cerca de nove por cento (9\%) dos participantes assinalaram não achar necessário, serem indiferentes ou não sabem opinar (Gráfico 29). Em se tratando dos alunos do curso a distância de Pedagogia, todos os participantes da pesquisa, vinte e dois alunos (22), afirmaram ser necessário ter disciplina(s) que ressalte(m) a relação das tecnologias e educação (Gráfico 30). 
Gráfico 29 - Necessidade da Disciplina sobre as TDICE na Graduação (Presencial)

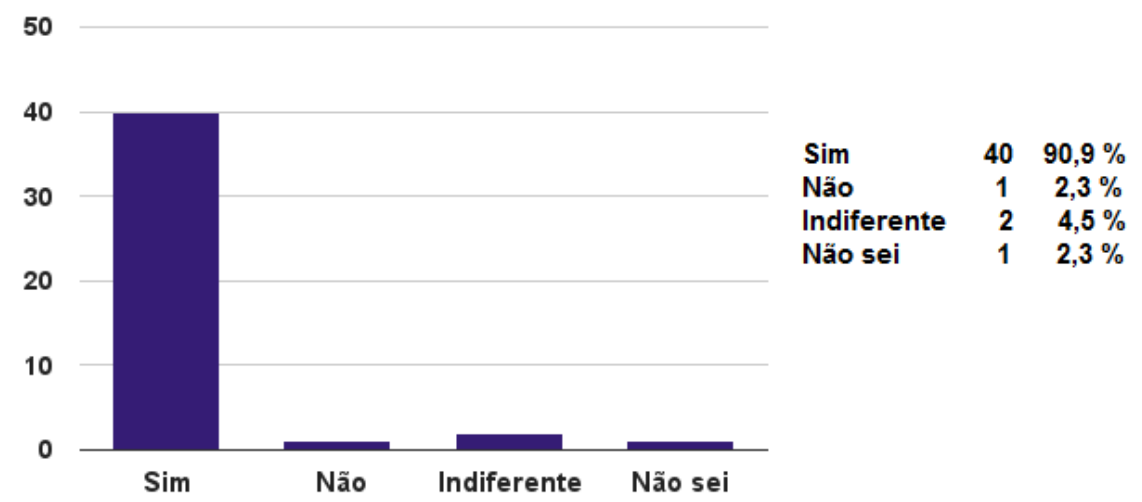

Gráfico 30 - Necessidade da Disciplina sobre as TDICE na Graduação (EAD)

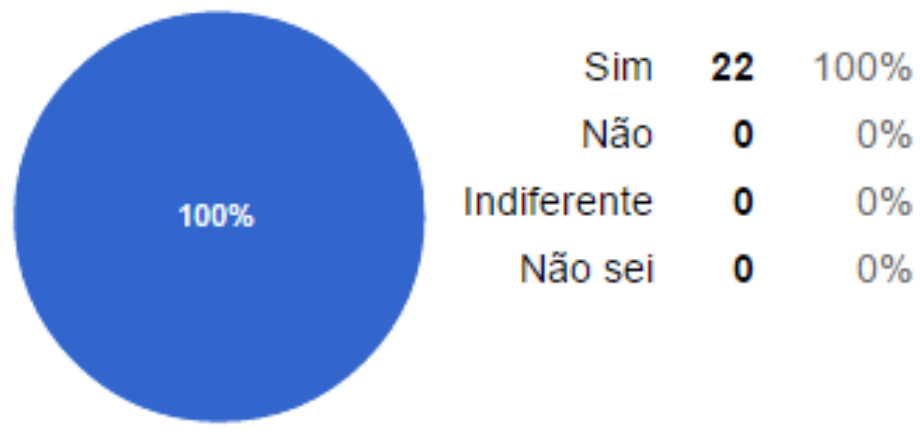

O participante PP4 relata que é muito importante ter disciplinas que abordem a temática estudada e menciona o contato com os alunos, geração que já nasce imersa na cultura digital, e problemas relacionados com a falta de preparo para trabalhar com este público.

PP4: Eu acho que sim até pra gente se orientar mesmo nesse mundo que a gente vive, porque eu acho que eu sou de outra geração até, as crianças que eu vou dar aula, elas são dessa geração já tá totalmente imersa, aí você pega um professor que às vezes não dá conta nem de ligar o próprio datashow.

O entrevistado PP5 afirma que deveria ter mais disciplinas que tratassem da temática (Educação e Tecnologias) sendo ofertadas aos alunos. $\mathrm{O}$ aluno ainda cita alguns conhecimentos que julga serem importantes na graduação para sua formação. $\mathrm{O}$ entrevistado PP6 expressa que seria muito importante que os alunos saíssem da graduação com os conhecimentos sobre as tecnologias na educação e escola. 
PP5: É, eu não fiz todas as disciplinas disponíveis, mas eu acho que assim, pelo tempo e pela disponibilidade até mesmo do nosso fluxo eu acho que deveria ter mais.

PP5: Deveria ter um pouco pelo menos assim, por exemplo, saber trabalhar com o word, porque muitos trabalhos da gente, todos os nossos trabalhos são digitados e a gente tem que fazer uma coisa acadêmica, e no final da nossa formação a gente tem que fazer a monografia. Por exemplo, pelo menos que ensinasse as regras da ABNT, a mexer com o word, coisas básicas de excel que a gente vai mexer um dia como professor né, fazer planilhas, esse tipo de coisas.

PP6: Porque eu acho que é importante você sair daqui com essa carga, e se ela... a faculdade disponibilizasse seria importante que todos saíssem daqui com essa carga.

Foi perguntado aos alunos do curso presencial de Pedagogia se eles já teriam cursado alguma disciplina integralmente ou parcialmente a distância (Gráfico 31). Cinquenta e nove vírgula um por cento dos participantes da pesquisa indicaram que não cursaram nenhuma disciplina, mesmo que parcialmente, a distância. E cerca de quarenta por cento $(40 \%)$ dos participantes afirmaram ter cursado alguma disciplina, integral ou parcial, a distância.

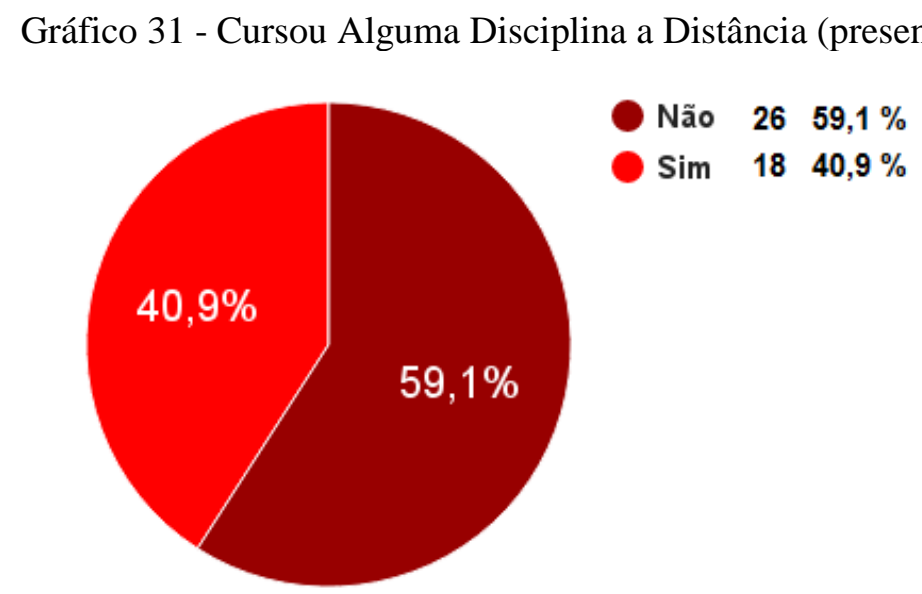

Em relação ao material didático e fontes de pesquisa utilizadas pelos alunos da modalidade de ensino a distância do curso de Pedagogia, a maioria dos participantes da pesquisa, noventa vírgula nove por cento $(90,9 \%)$ dos alunos afirmaram utilizar a internet como fonte de pesquisa. Cerca de sessenta e oito por cento (68\%) indicaram ter utilizado livros impressos; aproximadamente trinta e seis por cento (36\%) fizeram uso de revistas impressas; quatro (4) participantes fizeram uso de entrevistas com pessoas da 
área como forma de consulta e quatro vírgula cinco por cento $(4,5 \%)$ dos participantes afirmaram ter utilizado o recurso de vídeo por meio de fitas e DVDs (Gráfico 32).

Gráfico 32 - Fonte de Pesquisa (EAD)

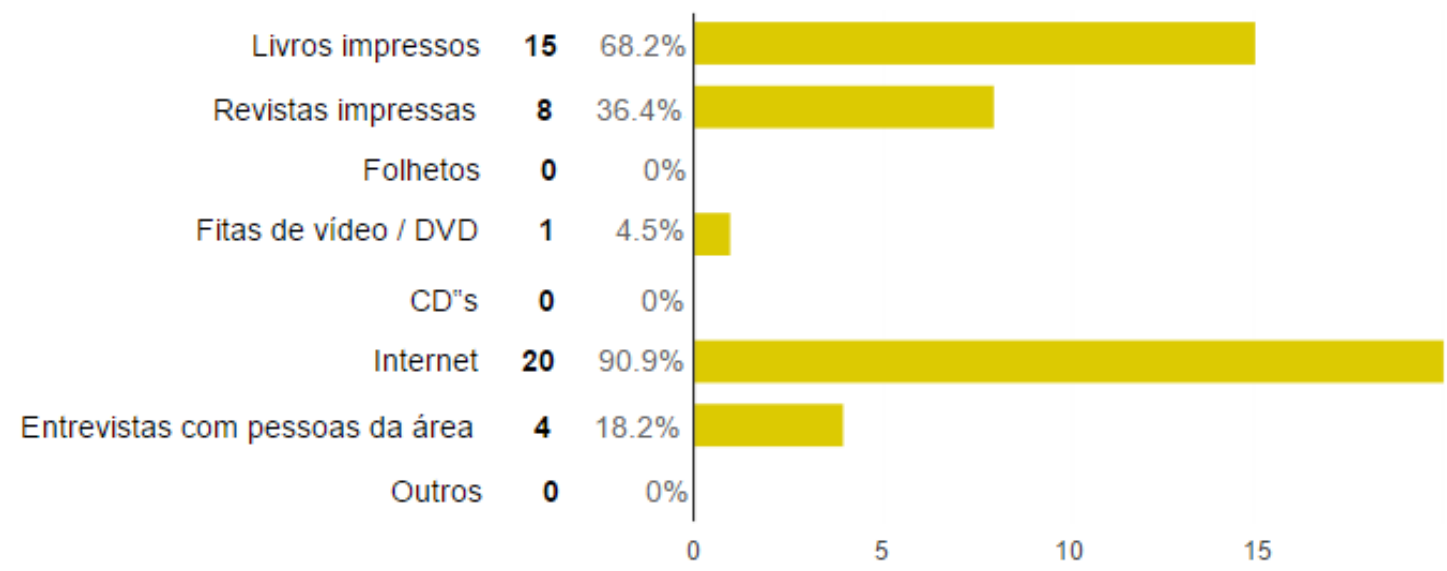

Percebe-se que a internet foi apontada como a maior fonte de pesquisa pelos participantes da pesquisa. Segundo Masetto (2013, p. 163), a internet é um grande recurso de aprendizagem múltipla: aprende-se a ler, a buscar informações, a selecionálas, a pesquisar, a comparar dados, a analisá-los, a criticá-los e a organizá-los. Desenvolvemos habilidades para utilizar e explorar esse novo recurso tecnológico com criatividade, valores éticos, políticos e sociais, na consideração dos fatos e fenômenos que chegam ao nosso conhecimento de todas as partes do mundo.

Um currículo que vislumbra a formação de professores para uma docência mediada pelas TDICE necessita promover ao aluno conhecimentos em relação à teoria e prática da temática. Lacerda Santos (2010, p. 24) cita que vários elementos podem ser identificados como eventuais integrantes de um currículo de formação de professores para a educação mediada pelas novas tecnologias da informação, comunicação e expressão. $\mathrm{O}$ autor descreve como principais:

- elementos formativos para o manuseio de ferramentas de desenvolvimento de materiais didáticos;

- conteúdos disciplinares referentes à compreensão da Sociedade Informacional e de seus impactos na organização do trabalho pedagógico;

- conhecimento sólido em Psicologia Cognitiva; 
- conhecimento sólido dos componentes curriculares (conteúdos) a fim de poder criar alternativas para sua abordagem em situação mediada;

- experiência concreta em aprendizagem mediada por NTICE.

Conforme dados levantados e baseado nos elementos identificados por Lacerda Santos (2010, p. 24) como eventuais integrantes de um currículo de formação de professores para a educação mediada pelas novas tecnologias da informação, comunicação e expressão, pode-se perceber:

Foram oportunizadas aos alunos opções curriculares para que eles pudessem obter o conhecimento sobre elementos formativos para o manuseio de ferramentas de desenvolvimento de materiais didáticos. A principal opção apontada foi por meio de disciplinas do curso. Percebe-se que estas disciplinas receberam muitas críticas com relação ao aprofundamento do conteúdo estudado e à falta de infraestrutura para o seu desenvolvimento. Alguns alunos abandonaram a disciplina pelo fato de a qualidade não estar sendo satisfatória.

Em relação aos conteúdos disciplinares referentes à compreensão da Sociedade Informacional e de seus impactos na organização do trabalho pedagógico, apesar de muitos alunos terem respondido que cursaram disciplinas sobre esta temática, pode-se observar pelas entrevistas que não tiveram uma disciplina que abordasse de forma mais aprofundada a temática. Pelos relatos pode ser percebido que alguns conceitos foram trabalhados de forma superficial em disciplinas optativas.

Quando falamos em experiência concreta em aprendizagem mediada pelas tecnologias, foi constatado que muitos alunos alegaram que não tiveram nenhum tipo de contato em sua graduação. Alguns alunos alegaram que tiveram contato com as tecnologias apenas como alunos. Não tinham conhecimento para utilizar a ferramenta tecnológica como professor com seus alunos. Também alguns alunos afirmaram ter tido experiência em aprendizagem mediada pelas tecnologias, mas em número muito pequeno em relação à totalidade de alunos participantes da pesquisa. Além de que, foram muito poucas as iniciativas dessa natureza oportunizadas aos graduandos. 


\title{
4.3 Os Docentes e as TDICE na Graduação
}

As instituições educacionais devem proporcionar aos seus alunos uma formação que lhes possibilite estar em consononância com os avanços científicos e tecnológicos ocorridos em nossa sociedade. As escolas têm o dever de ofecer todas as condições para que possam promover aos seus alunos uma formação de boa qualidade. Behrens, ao alertar sobre que tipo de formação se deve idealizar para os profissionais na sociedade contemporânea, faz críticas ao modo como tem sido esta oferta nas universidades.

\begin{abstract}
As exigências de uma economia globalizada afetam diretamente a formação dos profissionais em todas as áreas do conhecimento. Tornase relevante alertar que o profissional esperado para atuar na sociedade contemporânea exige hoje uma formação qualitativa diferenciada do que se tem ofertado em um grande número de universidades (BEHRENS, 2013, p. 75).
\end{abstract}

Nesta mesma linha de reciocínio, Lacerda Santos, Ferreira e Castro (2014, p. 52) relatam que independentemente da realidade vivenciada, a instituição escolar precisa assumir o compromisso da qualidade como forma de otimizar as transformações que a circundam e assegurar a sua identidade educativa em uma sociedade em rápido processo de mudança.

Para alcançar esta evolução significativa é necessário que aconteça uma mudança no modo de funcionamento de todo o sistema de ensino nacional. Desde as políticas públicas até a postura dos alunos e professores precisam ser alteradas para uma nova mentalidade. Faz-se muito importante também instrumentalizar e investir na formação que é ofertada nas universidades. É primordial introduzir mudanças no ensino-aprendizagem, nos modos de estruturação e funcionamento da escola e de sua relação com a comunidade. Ressalta-se o importante papel que terá o professor neste processo de mudança de conceitos e mentalidade dos alunos que serão o futuro do país.

Segundo Lacerda Santos, Ferreira e Castro (2014, p. 52), repensar a educação a partir dessa nova realidade e dos desafios que ela traz consigo requer a compreensão da função docente diante das possibilidades oferecidas pela informática educativa. Para os autores, o papel do professor na consolidação de uma nova mentalidade pedagógica, na 
preparação dos cidadãos para a sociedade emergente e na adequação do sistema educativo aos desafios da Sociedade Informacional é inquestionável.

Algumas iniciativas têm sido implementadas para a atualização da formação de professores que é ofertada nas universidades. No entanto, Nunes (2012, p. 52) alerta que embora tenhamos alcançado notável estágio de desenvolvimento científico e tecnológico, ainda estamos longe de atingir um patamar satisfatório de acesso às TDICE mais modernas e o domínio efetivo por parte de professores no uso dessas tecnologias, seja para atividades pessoais, seja para favorecer a aprendizagem dos alunos sob sua responsabilidade. Behrens cita que o professor tem que encarar as tecnologias

Com a visão de que a tecnologia está a serviço do homem e pode ser utilizada como ferramenta para facilitar o desenvolvimento de aptidões para atuar como profissional na sociedade do conhecimento, os professores precisam ser críticos para contemplar em sua prática pedagógica o uso da informática, oferecendo os recursos inovadores aos alunos (BEHRENS, 2013, p. 103).

A utilização de uma tecnologia digital no ambiente educacional pelo professor, com o intuito de propiciar a aprendizagem, precisa ser pautada por um planejamento pedagógico para que esta tecnologia possa fazer a diferença e agregar valor ao ensino/aprendizagem. Moran (2013, p. 32) alerta que há uma exigência maior de planejamento pelo professor de atividades diferenciadas, focadas em experiências, pesquisa, colaboração, desafios, jogos, múltiplas linguagens, e um forte apoio de situações reais e simulações. $\mathrm{O}$ autor elucida que

A transmissão de conteúdos dependerá menos dos professores, porque dispomos de um vasto arsenal de materiais digitais sobre qualquer assunto. Caberá ao professor definir quais, quando e onde esses conteúdos serão disponibilizados, e o que se espera que os alunos aprendam, além das atividades que estão relacionadas a esses conteúdos (MORAN, 2013, p. 32).

Quanto mais tecnologias, maior a importância de profissionais competentes, confiáveis, humanos e criativos. A educação é um processo de profunda interação humana, com menos momentos presenciais tradicionais e múltiplas formas de orientar, motivar, acompanhar e avaliar. Kesnki (2012, p. 66) observa que as TICs e o ciberespaço, como um novo espaço pedagógico, oferecem grandes possibilidades e desafios para a atividade cognitiva, afetiva e social dos alunos e dos professores de todos os níveis de ensino, do jardim de infância à universidade. Belloni (2005, p. 89) faz 
uma ressalva pontuando que o professor que participa de experiências diferenciadas de inovação tecnológica na educação deve estar capacitado não apenas para dominar os conteúdos da disciplina específica, mas também para dominar as novas linguagens típicas dos suportes tecnológicos utilizados.

Para tanto, além de uma infraestrutura satisfatória, um currículo atualizado com os avanços científicos e tecnológicos, a postura e o preparo dos professores vão ser determinantes para o sucesso de um projeto de educação mediado pelas TDICE. Caberá aos professores a tarefa de disciplinar a entrada das tecnologias na escola e na sala de aula. Planejar o emprego das tecnologias para que elas possam agregar valor ao ensino/aprendizagem.

Serão apresentados a seguir dados sobre a didática e a relação dos professores do curso de Pedagogia com as TDICE na graduação. Foi perguntado aos alunos do curso presencial de Pedagogia se os professores proporcionavam uma didática mediada pelas TDICE. Obteve-se como opinião de cerca de trinta e seis vírgula quatro por cento $(36,4 \%)$ dos acadêmicos que sessenta e cinco por cento (65\%) dos professores proporcionavam experiências mediadas com as TDICE (Gráfico 33). Para cinquenta e quatro vírgula cinco por cento $(54,5 \%)$ dos participantes da pesquisa, no máximo cinquenta por cento $(50 \%)$ dos professores com quem eles tiveram contato nas aulas proporcionavam uma docência mediada pelas TDICE. E somente nove vírgula um por cento $(9,1 \%)$ dos participantes afirmaram que todos os professores com quem eles trabalharam proporcionavam experiências didáticas com as TDICE.

Gráfico 33 - Docência Mediada pelas TDICE (Presencial)

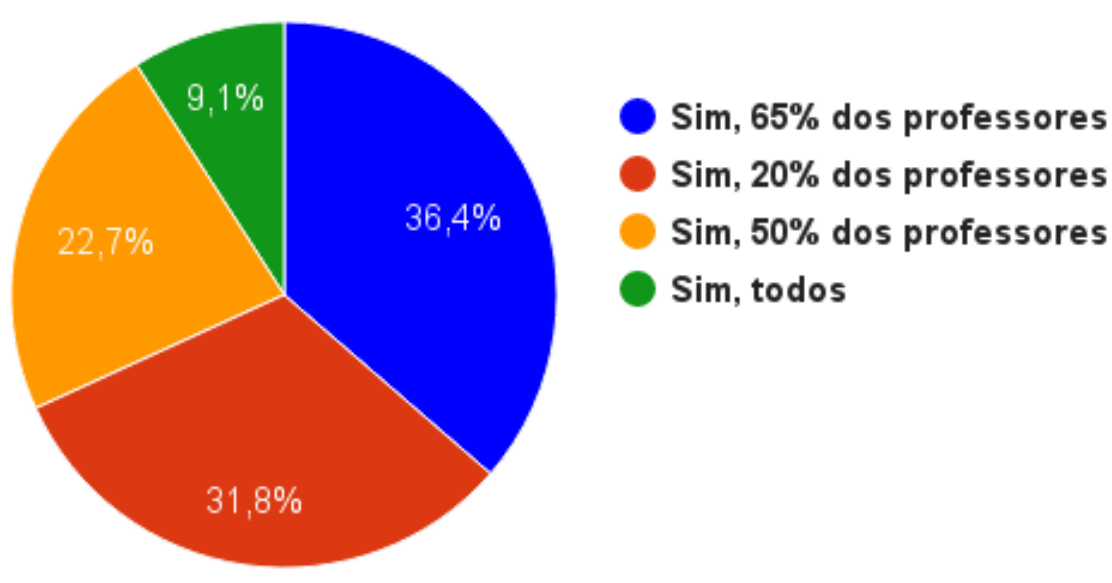


Quanto à avaliação dos alunos a distância do curso de Pedagogia (Gráfico 34), quarenta vírgula nove por cento $(40,9 \%)$ dos participantes assinalaram que todos os professores proporcionavam uma didática mediada pelas tecnologias educacionais. Para dezoito vírgula dois por cento $(18,2 \%)$ dos alunos, apenas no máximo vinte por cento dos professores utilizavam as TDICE em suas aulas. Cerca de vinte e dois vírgula sete por cento $(22,7 \%)$ dos participantes afirmaram que apenas cinquenta por cento (50\%) dos professores proporcionavam uma docência com as tecnologias.

Gráfico 34 - Docência Mediada pelas TDICE (EAD)
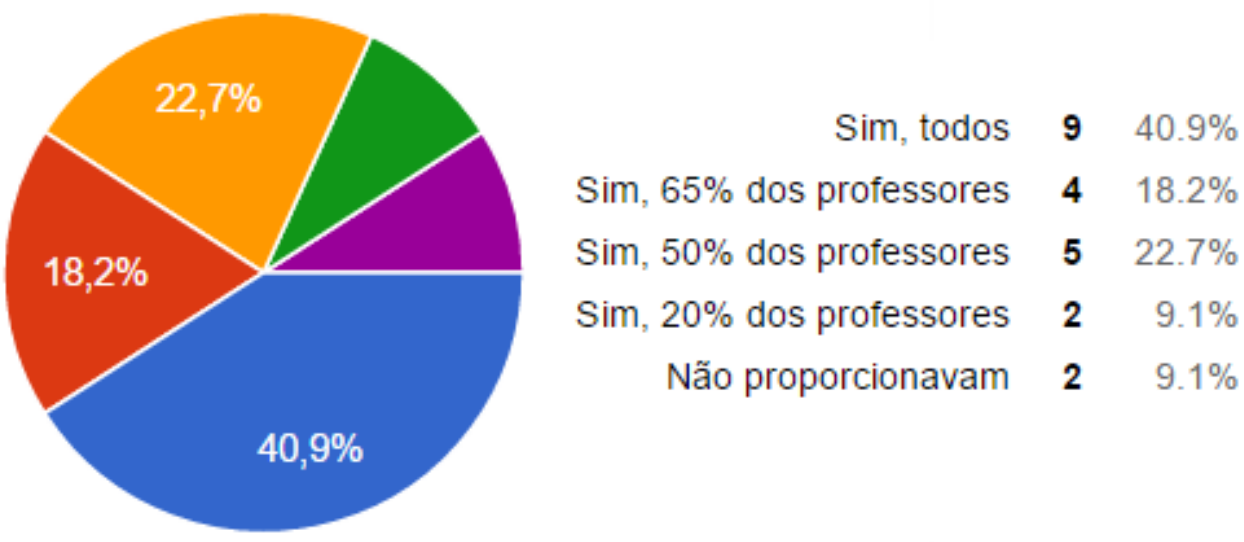

Trechos retirados das entrevistas ilustram a opinião dos alunos acerca da utilização das TDICE pelos professores na graduação. Foi apontada, por vários alunos, a utilização do Moodle como ferramenta tecnológica; a censura de alguns professores em relação à utilização de dispositivos digitais em sala de aula; a boa utilização de alguns professores das TDICE; a falta de preparo e conhecimento dos professores para lidarem com as tecnologias.

PP1: Assim, usa e tem professor que usa muito o Moodle e às vezes não é tão bom, porque o próprio sistema não é tão bom, mas eu acho que possibilita, mas não coisas muito, assim que diga assim que vai fazer tanta diferença na nossa formação.

PP2: Isso é muito difícil sabe? Porque eu tive professores aqui na faculdade que penalizavam os alunos por uso de celular dentro de sala de aula, e isso é uma prática muito errada sabe? Mas eu tive professores que a prática deles, mostravam assim, como fazer uso do ambiente interativo, do ambiente presencial, como utilizar das ferramentas de mídias, mídia digital, que tinham esse pacote completo sabe? Fazia uso da mídia digital, fazia uso do Moodle, fazia uso das mídias dentro da sala de aula. 
PP3: Não, eu acho que não, porque eles também não estão preparados, não tem como você ensinar uma coisa que você não sabe, além disso num tem recurso.

PP4: Não eu acho que não, as disciplinas também, eu acho que teriam outros recursos até pra usar, eu particularmente não gosto muito do Moodle que é o que eles mais usam, a plataforma que eles usam e eu acho que tem outros meios, mas às vezes os professores nem conhecem ainda. As vezes até pra apresentação de slides assim, tem uns sites muito legais, tem aplicativos muito legais. Os professores ficam presos às coisas que, muito antigas que talvez por não conhecerem.

Percebe-se que existem algumas diferenças nos percentuais de opinião em relação à modalidade de ensino dos alunos. Observamos que para a maioria dos alunos do curso a distância, sessenta e cinco por cento (65\%) ou mais dos professores tinham hábito de utilizar as TDICE em suas aulas; diferentemente do apontado pela maioria dos alunos do curso presencial, que indicaram que cinquenta por cento $(50 \%)$ ou menos dos professores oportunizaram ensinamentos mediados pelas TDICE.

Em relação à utilização de equipamentos e dispositivos digitais pelos professores em suas aulas, os alunos do curso presencial e a distância (Gráficos 35 e 36) assinalaram que a maioria dos professores fizeram uso de internet, computador e datashow em suas aulas. Também foi apontada, por quantidade inferior de alunos, a utilização de dispositivos como caixa de som, televisão, microfone, etc.

Gráfico 35 - Equipamentos digitais utilizados pelos professores (Presencial)

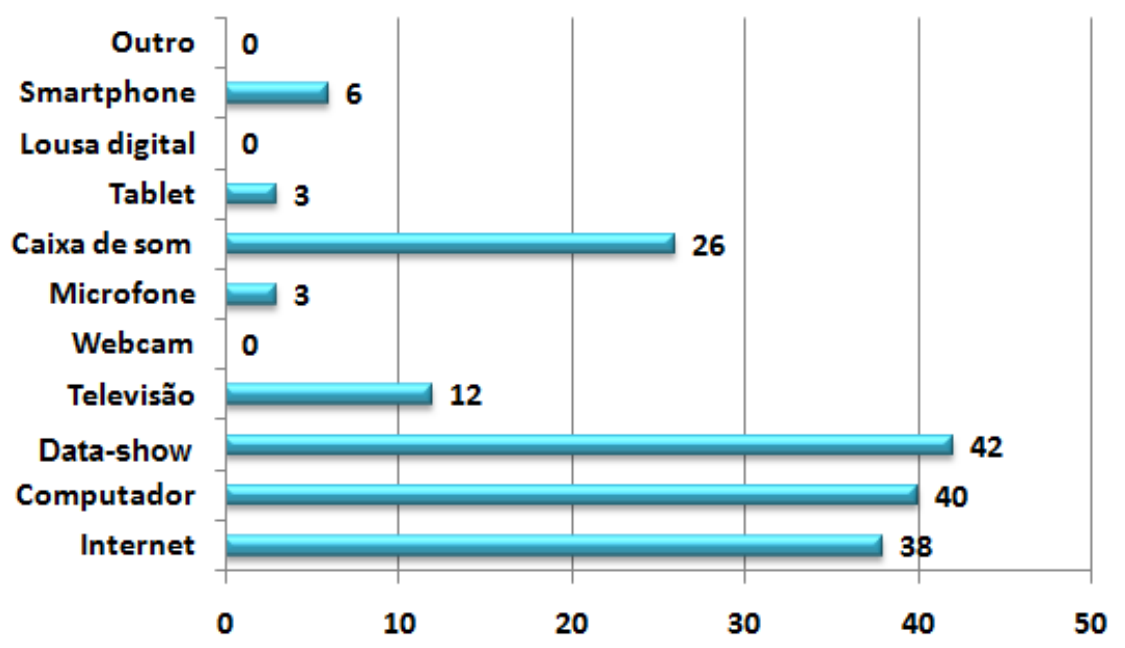


Gráfico 36 - Equipamentos digitais utilizados pelos professores (EAD)

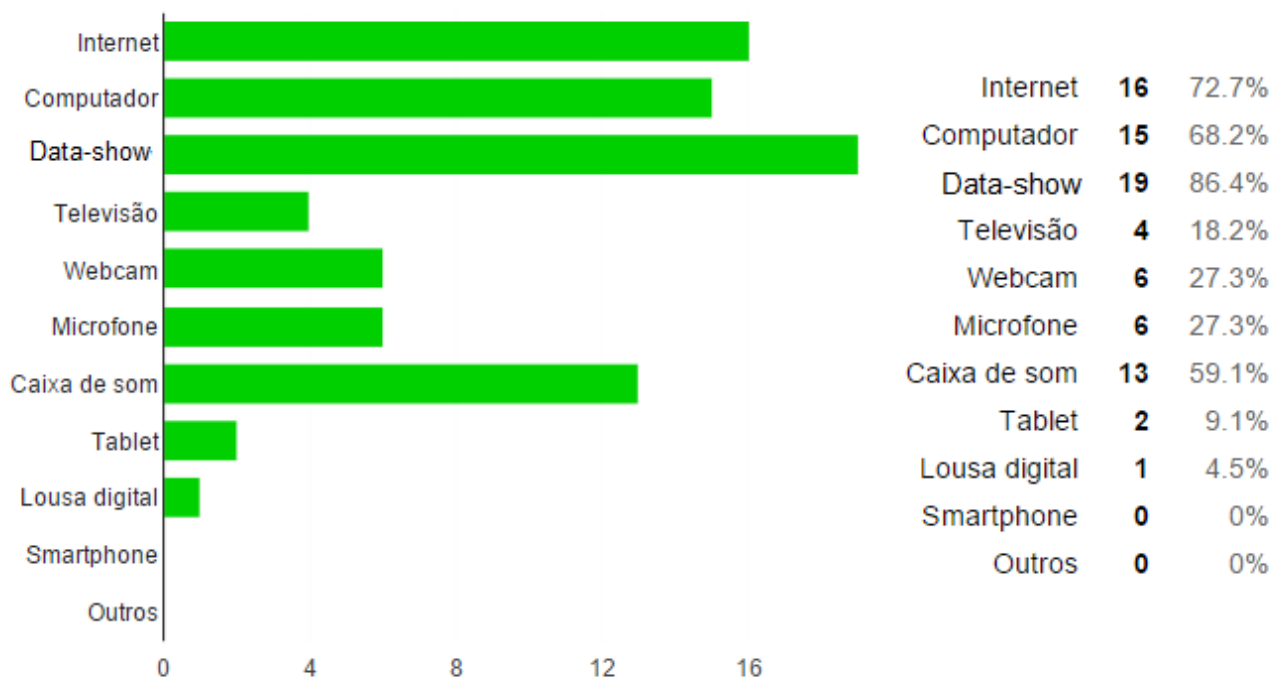

Quanto aos softwares utilizados mediante as demandas do curso, a maioria dos alunos participantes da pesquisa apontaram que fizeram uso dos softwares navegar de internet, editor de textos e criador de slides para auxiliá-los em suas tarefas acadêmicas (Gráfico 37 e 38). Também foi apontada em menor incidência a utilização de softwares para edição de vídeos e imagens, planilhas eletrônicas, gravadores de CD/DVD e jogos.

Gráfico 37 - Softwares Utilizados Mediante Demandas do Curso (Presencial)

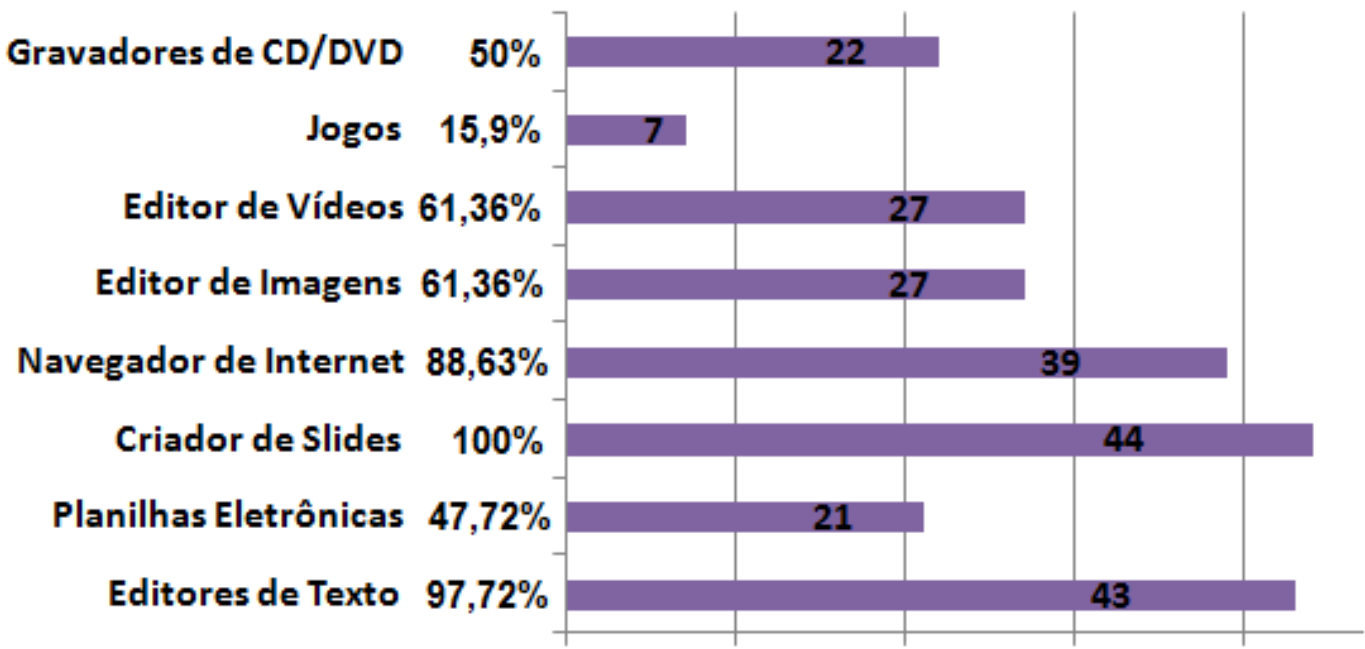


Gráfico 38 - Softwares Utilizados Mediante Demandas do Curso (EAD)

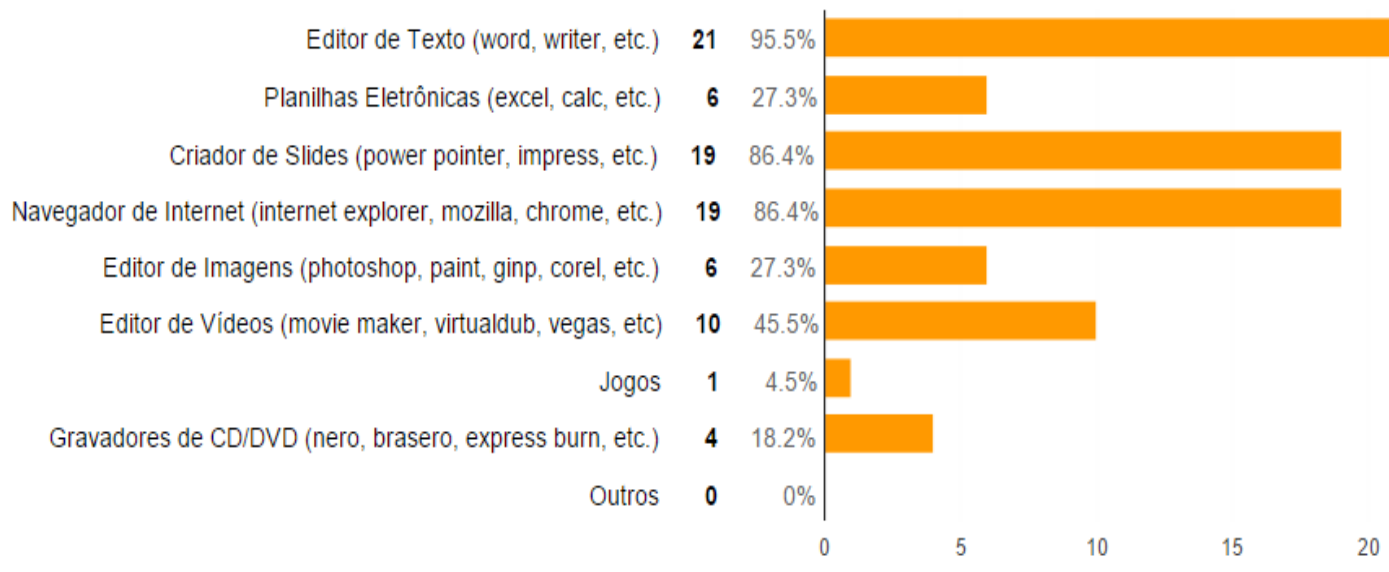

Em relação à comunicação entre professores e alunos, foi assinalado por quase cem por cento (100\%) dos alunos que a ferramenta mais utilizada foi o email (Gráficos 39 e 40). Os alunos do curso presencial apontaram que também se utilizam muito do Facebook (cerca de setenta e sete por cento - 77\%), sistema de gerenciamento acadêmico Saeweb ou Moodle (cerca de setenta e sete por cento - 77\%), Whatzapp (cerca de sessenta e três por cento - 63\%) além de blogs (cerca de quinze vírgula nove por cento $-15,9 \%)$.

Gráfico 39 - Softwares Utilizados para Comunicação com os Alunos (Presencial)

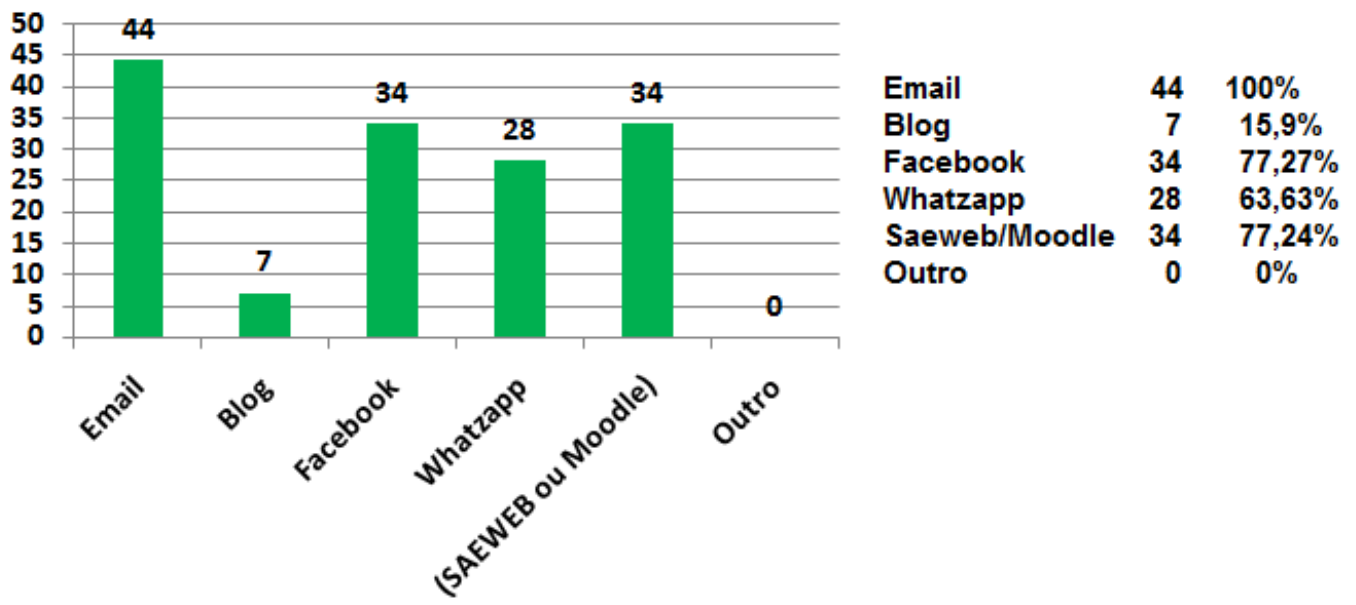

Os alunos do curso a distância apontaram que também se utilizam muito de chats (cerca de sessenta e oito por cento - 68\%), skype (cerca de sessenta e três vírgula seis por cento - 63,6\%), sistema de gerenciamento acadêmico Saeweb ou Moodle (cerca de cinquenta por cento - 50\%), Whatzapp (cerca de quarenta e cinco por cento $45 \%$ ) além de Facebook (cerca de nove por cento - 9\%). 
Gráfico 40 - Softwares Utilizados para Comunicação com os Alunos (EAD)

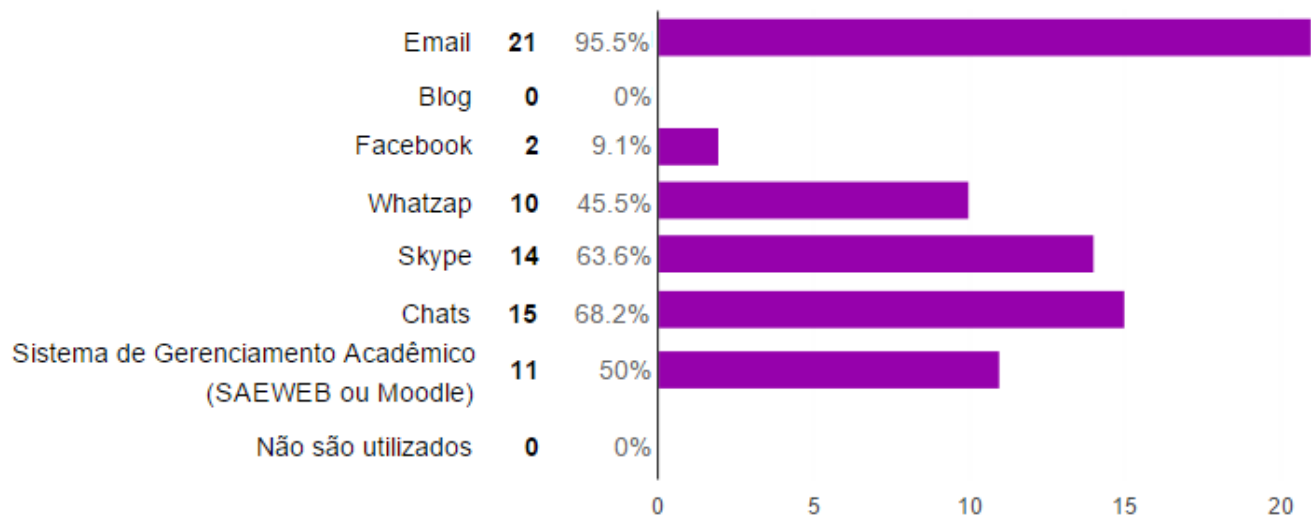

Quanto às finalidades didático-pedagógicas com que as TDICE (computadores, internet, tablets, etc.) são utilizadas pelos professores em suas aulas, os alunos participantes da pesquisa indicaram que as maiores finalidades da utilização das TDICE empregadas eram para introduzir conteúdos (para mais de oitenta e quatro por cento $84 \%$ dos participantes) e servir de instrumento de pesquisa (para mais de cinquenta e nove por cento - 59\% dos participantes) (Gráficos 41 e 42).

Os dois itens mais apontados confirmam uma grande utilização por parte dos professores dos recursos tecnológicos para montarem suas aulas, por exemplo, softwares para criar slides, apresentações nas quais o conteúdo poderá ser preparado para ser exposto aos alunos de uma forma muito fácil e rápida, economizando assim tempo para que possa se dedicar a outras atividades. O entrevistado PP2 confirma tal dado quando descreve, em um trecho da entrevista, que muitos professores utilizavam um software para criação de apresentações, e faz uma crítica em relação à forma que ele era utilizado em sala pelos professores.

PP2: Mas boa parte assim, 90\%, se disser que usa algum tipo de mídia é o PowerPoint assim, e nem fazer isso direito de uma forma que age na interação ao aluno, com aquilo ali acaba tornando uma aula maçante, que tipo, boa parte dos alunos acabam dormindo, pessoal do noturno, quando a aula era expositiva, o professor apagava a luz, quando ligava metade da turma tava dormindo. 
Confirma também o grande poder que as tecnologias têm para serem utilizadas como instrumento de pesquisa. Torna-se muito fácil, ágil e cômodo fazer pesquisas sobre os mais variados assuntos utilizando ferramentas tecnológicas e a internet.

Gráfico 41 - Finalidades Didático-pedagógicas das TDICE (Presencial)

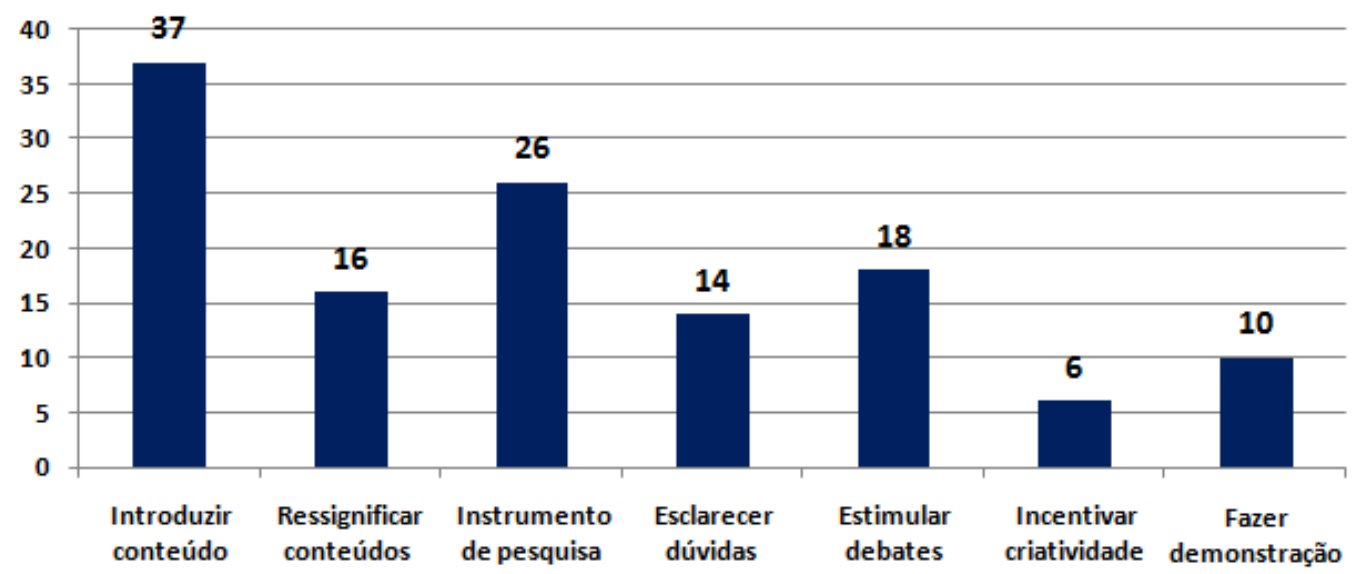

Chama a atenção a opinião dos alunos quando somente menos da metade aponta que as TDICE foram utilizadas pelos professores em demonstrações práticas em situação de aprendizagem. Dado que confirma o pouco contato dos alunos com seu preparo para saber lidar e operar com as TDICE em sala de aula em situação de ensino/aprendizagem. Preocupação manifestada por parte dos alunos pesquisados: saber utilizar as ferramentas tecnológicas didaticamente com seus alunos para propiciar situações de aprendizagem. O participante da pesquisa PP10, em entrevista, confirma tal situação quando relata sua intenção de aprender a lidar com as TDICE na prática.

PP10: Eu acredito que assim, na minha opinião eu acho que deveria ser abordado também, igual a gente fez estágio e tudo. Ter um aprofundamento maior né, pra ajudar o educador, assim na questão de como tratar com a tecnologia, usar ela como aliada, não atrapalhando também né, a parte docente. Mais assim, usando ela como aliada e saber usar, eu acho que é um ponto muito positivo, tem que saber usar né.

O entrevistado PP7 relata que em muitas das práticas envolvendo as tecnologias na graduação a turma teve contato enquanto aluno, não enquanto professor e que poderia obter um conhecimento e aplicar em sua prática em sala de aula como professor. 
PP7: Não, os professores que utilizam o Moodle, ensinam como você ser professor no ambiente Moodle, isso aí só como aluno e muitas vezes nem ensina como você ser aluno no Moodle, você tem que aprender sozinho a se virar e aprender a mexer na plataforma.

Já o entrevistado PP6 relata que os professores oportunizaram experiências práticas com as TDICE na graduação, mas que o aluno tinha o inconveniente de não ter à sua disposição os computadores na universidade para praticar o aprendido e fazer as atividades práticas.

PP6: Ah, eu acho que isso proporciona, mas acaba naquele embarreiramento de que, por exemplo, a gente que não tem como fazer em casa. E aí chega pra fazer aqui na universidade e não tenho um aparelho disponível.

Outro ponto também preocupante diz respeito ao baixo incentivo à criatividade na graduação. As TDICE são ferramentas poderosas para a expressão da criatividade. Observamos que pouco têm sido utilizadas para este fim. Lacerda Santos (2010, p. 24) indica esta falta de crédito que se tem atribuído à criatividade na graduação e elucida que

A criatividade do professor, elemento que tampouco é explorado em cursos de formação docente, é um instrumento essencial para que seja assegurada a dinamização da sala de aula interativa e a reinvenção dos materiais didáticos, sejam eles convencionais ou inovadores, em função de necessidades específicas de relações educativas específicas.

A criatividade é um fenômeno complexo, multifacetado e pouco explorado, sobretudo no ambiente educacional, e não há como negar sua importância no contexto escolar e a necessidade de promovê-la na formação dos alunos. A contemporaneidade requer professores criativos que formem alunos criativos. Cada vez mais, a criatividade do professor é elemento fundamental no processo educativo devido à necessidade de atualização da escola e à demanda de uma sociedade em permanente transformação. Segundo Mitjáns Martínez (2002, p. 195),

Reconhece-se a necessidade de professores criativos para desenvolver a criatividade nos alunos, e, conseqüentemente, a promoção da criatividade dos professores emerge como via para alcançar maiores níveis de criatividade nos educandos. 
Trabalhar a criatividade é uma forma de deixar qualquer aula mais dinâmica e proveitosa, pois incentiva os alunos a participarem com maior dedicação. Sem se preocupar com a disciplina, estimular a criatividade é uma forma de os professores darem a chance de seus alunos irem atrás do conhecimento, de fazerem descobertas, de identificarem elementos fundamentais para se comprovar as teorias e os conteúdos escolares. A ação criativa do professor em sala de aula demanda não só sua capacidade de elaborar atividades inovadoras que permitam atingir os objetivos educativos de forma mais eficiente, mas também demanda habilidades comunicativas que lhe permitam criar um espaço comunicativo que se constitua no espaço onde as atividades podem fazer sentido para o desenvolvimento da criatividade (MITJÁNS MARTÍNEZ, 2002, p. 196).

Gráfico 42 - Finalidades Didático-pedagógicas das TDICE (EAD)

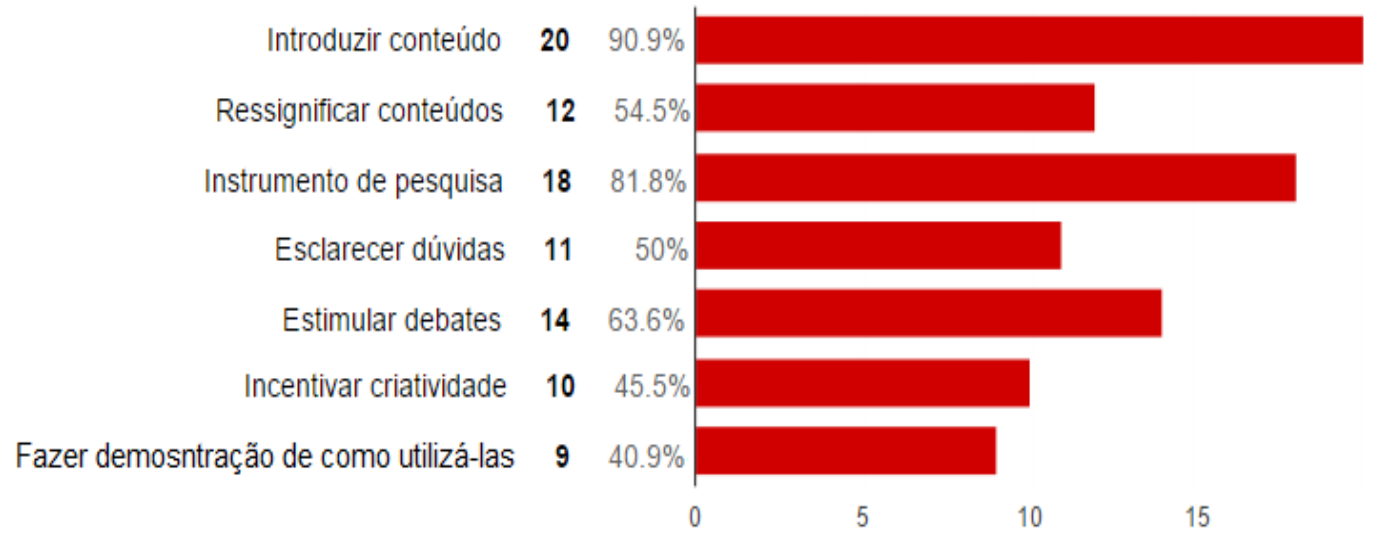

O entrevistado PP5 faz um relato sobre como era a utilização das TDICE pelos professores na graduação e como ele assimilava e observava esta relação.

PP5: Eu acho que os professores eles não dominam esse uso, mas acabaram gerando isso na gente, porque a gente tinha que aprender pra poder apresentar os trabalhos né. Então acho que a gente buscou isso mais autodidatamente né! Mas eu acho que os professores, por exemplo, eles não sabem nem ligar um data-show, então assim, eu acho que é falta de informação mesmo, e são doutores né, então você ver que não é só... as pessoas geralmente consideram essas pessoas os excluídos geralmente são os ignorantes, mas não é né, são os doutores, então ligar um data-show é uma coisa simples. Então acho que essa informação deveria chegar a todos pelo menos eles saberem utilizar o computador, data-show ter essas informações, eu acho que a aula seria mais... assim, gastava entre um tempo bom assim de aula, né uns 30 minutos. 
O participante PP5 relata que alguns professores não têm o domínio das tecnologias e que os alunos acabavam aprendendo sozinhos de forma autodidata pela necessidade. Menciona a dificuldade dos professores em utilizar as ferramentas tecnológicas e questiona o processo de formação e atualização da classe docente. Finaliza sua fala ressaltando os benefícios que os alunos poderiam ter com o emprego das tecnologias em aulas, como a economia de tempo para preparar o material didático que vem atrelado à facilidade, comodidade.

Percebe-se pelos dados coletados que os alunos tiveram contato com as TDICE na graduação em diferentes situações, seja para utilização como meio de comunicação, seja em sala de aula ou fora, para realização de trabalhos escolares, etc. Percebe-se também que grande parte dos professores fazem uso das tecnologias em sua prática docente, mas houve muitos questionamentos pelos alunos em relação à forma com que estes professores empregavam a tecnologia em sala. Relataram que muitos dos professores tinham dificuldades em lidar com as tecnologias, alguns até proibiam o uso, outros não sabiam utilizar ou não proporcionavam ensinamentos para que os alunos pudessem aplicar na prática como futuros professores.

\subsection{TDICE na Sala de Aula}

O avanço científico e tecnológico fez surgir mudanças em nossa sociedade que se manifestaram de forma intensa na educação. Demandas educacionais têm sido levantadas para a escola em meio à criação de modelos organizacionais que surgiram das mudanças no mundo do trabalho; do aumento na produção de novos conhecimentos; do crescimento das TDICE; da globalização que trouxe mudanças não só no âmbito econômico, mas também social; no papel do Estado; nos novos padrões de comportamentos e significação em relação à família, arte, consumo, cultura e formas de pensar e compreender a vida socialmente.

A educação vem passando por uma grande quantidade de mudanças em sua constituição e forma de atuação perante as transformações que ocorreram em nossa sociedade. A escola precisa estar a par das transformações alavancadas em um ambiente social que vive em mutação. Carvalho Nunes observa que a educação necessita se 
modificar e adequar a uma nova realidade para poder preparar os cidadãos para se desenvolverem perante a nova sociedade. $\mathrm{O}$ autor descreve que

[...] em razão das demandas postas pela atual sociedade da informação e do conhecimento, a educação é conclamada a se modificar, seja na tentativa de humanizar processos de tecnologização das relações sociais, seja na busca de contribuir com a formação de cidadãos preparados para atuarem em face da flexibilidade e da mutabilidade do mundo contemporâneo (CARVALHO NUNES, 2012).

Vários segmentos de nossa sociedade foram se modificando e adequando conforme as mudanças que a sociedade passava. A educação também passa por essas mudanças impulsionadas pelos avanços científicos e tecnológicos, só que a um ritmo muito menor em relação aos outros setores da sociedade. O entrevistado PP4, observando o cenário atual de desenvolvimento da nossa sociedade, faz um relato sobre a aproximação que deve haver entre a educação e as tecnologias. Para ele, a educação tem que andar junto com as tecnologias pelo fato de os alunos, geração dos mais jovens, já estarem imersos na cultura digital. O participante ainda chama atenção para o papel do professor neste processo de mediação.

PP4: Hoje em dia a tecnologia tá em tudo assim, por que que não estaria na educação?! E é uma coisa que chama a atenção da maioria dos jovens, de qualquer classe, de qualquer âmbito que tenha, todo mundo tá imerso na tecnologia. Então, eu acho que a educação tem que andar junto como eu te falei. O professor ele pegar essas coisas e trazer pra si, porque eu vejo muita gente que olha com olho torto, não quer usar, tem medo e tal, mas eu acho que tem aproximar essas tecnologias da sala de aula mesmo.

Belloni (2005, p. 17) relata que a entrada das TIC nas escolas ocorreu, sobretudo, como resultado da pressão do mercado, estando a instituição escolar em franca defasagem com relação às demandas sociais e à cultura das gerações mais jovens. Neste sentido, Lacerda Santos e Firmino (2014, p. 47) fazem uma observação quanto à forma indisciplinada com que as tecnologias estão chegando às escolas. Os alunos estão trazendo para o microcosmo que é a escola as demandas e os anseios da sociedade, cujos aspectos socioeconômicos, políticos e de relações sociais já foram transformados pelas TDICE. 
Corroborando com este pensamento, o participante PP2 observa que a educação não pode mais andar separada das tecnologias. A escola tem que se atualizar com as mutações ocorridas na sociedade.

PP2: Acredito que na hora de construir conhecimento, fazer o uso, por exemplo, de filmes, documentários, trazendo uma interação com outras culturas, possibilita essa interação por meio da internet, por meio de ferramentas né, eu acho que educação e tecnologia hoje elas não podem mais ficar separadas.

Já o entrevistado PP6, em sua fala, salienta a relação próxima dos alunos com as tecnologias e elucida a necessidade de orientação do professor na condução das atividades pedagógicas com as ferramentas tecnológicas.

PP6: [...] porque tudo hoje em dia tá voltado pra tecnologia né, então é uma coisa que tem que tá dentro do mundinho dos alunos. Parte do desenvolvimento. Se não tiver uma orientação correta da forma de usar, talvez tenha sim um ponto negativo.

Para Oliveira, Nunes e Dos Santos (2012, p. 95), a inserção das TICs na escola exige forma diferenciada de conceber o ensino e a aprendizagem. Trata-se da preocupação de potencializar os equipamentos da instituição, de modo que os docentes possam utilizá-los a serviço do cumprimento da função social da escola. O entrevistado PP9 enaltece as possibilidades que o professor tem em trabalhar com as tecnologias e faz ressalva em relação à capacidade de motivação e instigação da curiosidade dos alunos.

PP9: Usar as mídias como ferramenta é interessante né, usar vídeos, palestras, filmes, esses filmes educativos que a gente tem acesso, é muito válido né, tem a lousa digital, tem hoje em dia com essas multitecnologias disponíveis, vai causar um impacto muito interessante porque são coisas que atrai a curiosidade do aluno, e nós sabemos que o aprender, ele se resume a questão de interesse, então se o aluno ele demostra, ele se ver motivado, a mediação torna-se muito facilitada.

É imprescindível pensar na utilização das TICs como possibilidades de reformulação do conhecimento. A introdução de tecnologias no setor educacional não pode pretender resolver e/ou acabar de uma vez por todas com os problemas educativos de sempre, mas pode, sim, introduzir melhorias no âmbito de uma reforma educacional 
e de uma política nacional que se integrem de forma pertinente (OLIVEIRA, NUNES e DOS SANTOS, 2012, p. 96). Os autores assim esclarecem os objetivos da inserção das tecnologias na educação,

As TICs devem ser introduzidas à escola com o objetivo de contribuir para expandir o acesso à informação e de estimular a elaboração do conhecimento, estabelecendo novas relações com o saber produzido (OLIVEIRA, NUNES e DOS SANTOS, 2012, p. 97).

Ensinar utilizando as tecnologias traz uma série de desafios cada vez mais complexos. De um lado, temos mais informação, variedade de materiais, canais, aplicativos, recursos. Essa variedade exige capacidade de escolha, avaliação e concentração. Nunca tivemos tantas facilidades, mas elas podem complicar o processo, tanto em nível institucional como pessoal (MORAN, 2013, p. 57). O autor salienta que

Com as tecnologias atuais, a escola pode transformar-se em um conjunto de espaços ricos de aprendizagens significativas, presenciais e digitais, que motivem os alunos a aprender ativamente, a pesquisar o tempo todo, a serem proativos, a saber tomar iniciativas e interagir (MORAN, 2013, p. 31).

Foi perguntado aos participantes da pesquisa qual seria a sua opinião em relação à inserção das tecnologias nas salas de aulas (Gráficos 43 e 44). Os alunos do curso presencial e a distância demonstraram opiniões similares. Cerca de cinquenta e quatro por cento $(54 \%)$ dos participantes da pesquisa afirmaram ser favoráveis a inserção das TDICE nas salas de aula. E aproximadamente quarenta e seis por cento (46 \%) dos alunos disseram que são a favor da inserção das tecnologias, mas com algumas restrições. Nota-se que não houve opiniões contrárias à utilização das TDICE nas salas de aula. O entrevistado PP2 observa que atualmente os alunos já estão submersos na cultura digital e acabam levando para a escola dispositivos tecnológicos os quais não podem ser mais ignorados pelos professores que devem desenvolver uma didática para aproveitar o potencial pedagógico dessas tecnologias.

PP2: Eu acho que não tem como você, por exemplo, dizer para o seu aluno que ele não vai levar pra dentro da sala de aula como era feito um dia, uma parte das crianças hoje já têm smartphone. Eu acho que o professor tem que achar um meio de tornar uma ferramenta pra construção de ensino, construindo aulas interativas, fazendo o uso de mídia social pra disponibilizar materiais, disponibilizar conhecimento, fazer vídeo com os alunos, fazendo trabalho onde eles construam coisas que interagem com as 
mídias sociais, e que isso traga aproximação benéfica sabe?! Dessas ferramentas pra dentro da sala de aula.

Os entrevistados PP4 e PP7 entendem que não existem restrições para o emprego das tecnologias na sala de aula. O entrevistado PP4 realça as mudanças na nossa sociedade e a importância profissional de haver uma formação para trabalhar com as tecnologias.

PP4: Eu acredito que não, eu dou aula pra criança de dois aninhos, eles já nascem imersos nessa tecnologia, o dedinho já tá nervoso ali procurando, ele já sabem ligar, desligar, tirar do aplicativo até comprar joguinho e não sei o quê, e é uma geração que assim, que os livrinhos já não chama mais tanta atenção, brincar na areia já não chama mais atenção, entre o Ipad e o chão eles querem o Ipad, então é inevitável. Eu acredito que toda, inclusive a educação de jovens e adultos se fosse possível assim, geralmente é público que não tá incluído digitalmente né. E mais que seria interessante até na perspectiva profissional e tal, porque como eu te falei o mundo hoje é tecnológico, é todo digital.

PP7: Não pra mim não tem restrição nenhuma, desde a creche até o ensino superior tem como utilizar a tecnologia.

Gráfico 43 - Tecnologias nas Salas de Aulas (Presencial)

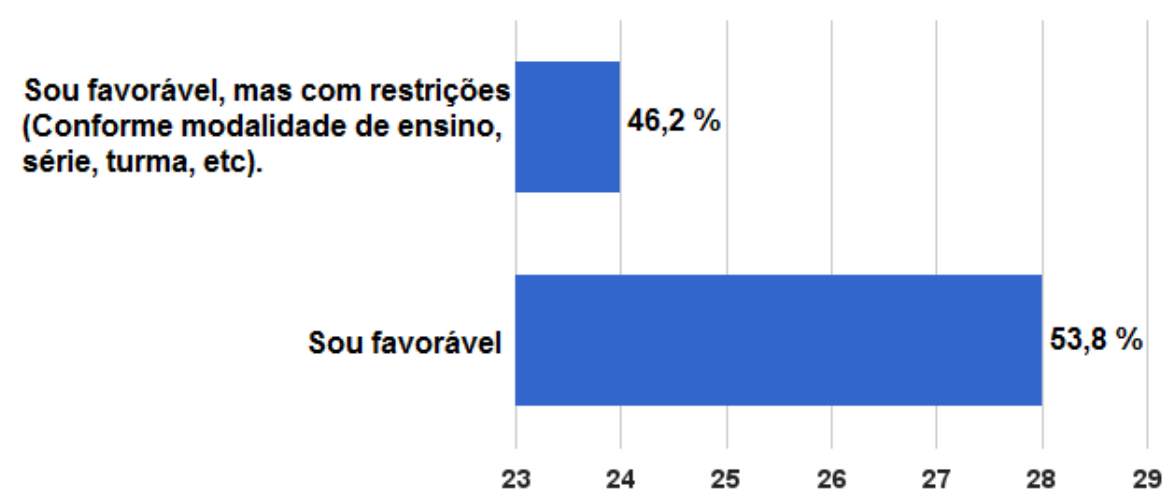

Gráfico 44 - Tecnologias nas Salas de Aulas (EAD)

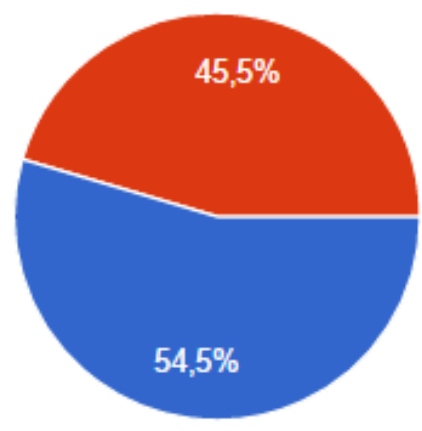

Sou favorável. $12 \quad 54.5 \%$

Sou favorável, mas com restrições (Conforme modalidade de ensino, série, turma, etc). 
Em se tratando das restrições (Gráficos 43 e 44), foram levantadas em relação à idade, à parte financeira (aquisição de equipamentos), à intensidade da utilização (não ficar preso somente as tecnologias) e planejamento pedagógico (as atividades precisam ser planejadas pedagogicamente para que possam agregar valor ao ensino/aprendizagem). Os alunos PP1, PP2, PP3, PP9 e PP10 ilustram tais aspectos em trechos retirados das entrevistas.

PP9: Não, a única restrição que eu vejo é financeira que hoje em dia, é o que eu te disse tá todo mundo ligado.

PP2: Bom, eu acho que... que assim, existem algumas coisas que você não deve expor pros seus alunos dependendo da idade né, por conta de vários riscos que é a internet, de vários riscos que esses meios oferecem de determinadas idades, então eu acho que como tudo na vida você tem que ter discernimento de qual idade, e de como utilizar essa ferramenta em cada um desses níveis.

PP3: Eu acho que é bom, eu acho que é bom, eu acho que atende uma demanda das pessoas já estão nascendo nessa era tecnológica, mas eu acho que no caso do Brasil ainda é muito complicado porque mais de $40 \%$ não têm acesso nem à geladeira, à televisão né, então também não têm acesso às novas tecnologias, na minha opinião tá restrito ainda a uma pequena parcela da população.

PP10: Assim, oh eu ainda não trabalhei, mas assim o que eu vejo é que ele pode ser positivo em algumas atividades, também não acredito que ele deva ser usado todo tempo né, no processo de ensino-aprendizagem. Eu acho que ele tem que ser usado, mas moderadamente.

PP10: Não, assim, eu não acredito que não, eu acho que tem que saber usar né, e adequar com a faixa etária de cada turma.

PP1: Eu acho que tem que ter cuidado, por exemplo, principalmente na educação infantil, as crianças são muito ligadas a jogos, nem sempre são jogos que vão auxiliar no desenvolvimento delas, são jogos mais à toa mesmo, esse é ponto negativo ver onde tá sendo dispersado e onde realmente vai ajudar o desenvolvimento da criança.

São muitos os benefícios em se empregar as TDICE na sala de aula e no processo de ensino e aprendizagem. Segundo Masetto (2013, p. 149), estas são as oportunidades que a informática e a telemática proporcionam a seus usuários - dentre eles, obviamente, alunos e professores: 
- oportunidade de entrar em contato com as mais novas e recentes informações, pesquisas e produções científicas do mundo todo, em todas as áreas;

- oportunidade de desenvolver a autoaprendizagem e a interaprendizagem a distância, valendo-se dos microcomputadores que se encontram disponíveis a todas as pessoas, permitindo o surgimento de novas formas de construir o conhecimento, realizar as atividades didático-pedagógicas, produzir trabalhos monográficos e relatórios científicos;

- possibilidade de integrar movimento, luz, imagem, som, filme, vídeo em novas apresentações de resultados de pesquisa e de temas para as aulas;

- possibilidade de orientar os alunos em suas atividades não apenas nos momentos de aula, mas nos períodos "entre aulas" também;

- desenvolvimento da criticidade para se situar diante de tudo o que se vivencia por meio do computador e aprender a selecionar o que é verdadeiro e relevante para seu desenvolvimento;

- incentivo à curiosidade para buscar coisas novas; e, por fim, colaboração para a reflexão crítica e ética diante dos valores contemporâneos.

Nesta direção, os entrevistados PP5 e PP7 relataram alguns dos pontos positivos em se aproximar a educação das TDICE. Dentre os benefícios foi citada a possibilidade de trabalhar atividades lúdicas, sair das aulas maçantes (quadro e giz), preparar o aluno para o mercado de trabalho e as possibilidades que elas proporcionam como suporte às aulas.

PP5: Acho que tem pontos positivos e negativos também, mas eu acho que na maioria eu vejo como positivo, porque eu acho que ajuda o professor né? Porque as escolas precisam de algo mais lúdico né, não só de quadro e giz, porque fica uma aula maçante, acredito que essas novas tecnologias vêm pra agregar e não pra.... negativar esse processo de ensinoaprendizagem.

PP7: Ah, eu acho que tem pontos muito positivos, porque não tem como hoje em dia você ficar afastado da tecnologia, no século que nós vivemos, a gente tem que tá muito atrelado à tecnologia e usar como um suporte pra nossas aulas. Eu acho uma boa ideia, porque envolve o aluno também e faz com ele fique mais preparado até para o mercado de trabalho, que às vezes não tem condições de fazer curso de informática e aquele contato nem que seja no computador na escola já facilita quando ele for trabalhar.

Foram apontados também os benefícios que podemos obter ao empregar as TDICE como forma de acessibilidade no trabalho com alunos com necessidades 
especiais. Os entrevistados PP1 e PP9 relatam experiências com as tecnologias que agregaram valor ao aprendizado com alunos com necessidades especiais.

PP9: Vejo pontos positivos tá? Porque são ferramentas que atraem. E com o recurso das mídias dentro da sala de aula você pode atrair a atenção desse aluno..., você muda a cor da tela da fonte pra despertar, introduzi um áudio pra verificar se aquele aluno compreendeu através daquela frequência que tá sendo emitida pra ele, quer dizer a ferramenta que a tecnologia oferece, ela tem inúmeros recursos que podem facilitar o aprendizado, mostrando para o aluno a sua forma de aprender, bem como facilitando também o trabalho do professor.

PP1: Eu acho interessante assim eu mesmo sou do grupo da educação especial e no meu projeto quatro eu tive um aluno que era super antenado, então o modo que eu tinha de conseguir passar alguma coisa pra ele era através do computador, era através dessas mídias assim, então eu acho muito importante para os alunos terem esse tipo de contato mesmo.

PP1: Eu acho que... pois é indo pelo lado desse aluno que tem síndrome de down ele, a gente fazia muito jogos com ele de... Ele jogando ele tinha coordenação muito legal, que ele talvez não tinha em outras coisas, assim sei lá, com caneta, as coisas assim... e com os jogos ele conseguia desenvolver aquilo. Então isso eu acho interessante ter, eu acho importante ter na educação infantil.

Para Kenski (2012, p. 45), a imagem, o som e o movimento oferecem informações mais realistas em relação ao que está sendo ensinado. Quando bem utilizados, provocam a alteração dos comportamentos de professores e alunos, levandoos ao melhor conhecimento e maior aprofundamento do conteúdo estudado. As tecnologias dependem de como professores, alunos e gestores as utilizam: em contextos e encontros pedagógicos motivadores ampliam a curiosidade, o interesse, a pesquisa, a interação. As tecnologias em contextos e encontros pedagógicos acomodados, rotineiros aumentam a previsibilidade, o desencanto, a banalização da aprendizagem, o desinteresse.

Os entrevistados demonstraram uma grande preocupação com a forma de utilização das TDICE em sala de aula. Para eles, é necessário um planejamento pedagógico para o emprego ou utilização de uma ferramenta tecnológica. A utilização da tecnologia sem objetivo/plano acaba por não trazer o retorno esperado: a “aprendizagem dos alunos". Em muitos dos casos, gera a dispersão e distração dos 
alunos, o que resulta em atrapalhar a relação de ensino/aprendizagem. Os entrevistados PP1, PP2, PP4, PP5 e PP6 demonstram tal preocupação em suas opiniões.

PP4: Na escola que eu trabalho as crianças têm uso do Ipad, eu acho o uso da tecnologia ele tem que ser muito bem planejado, porque você pode cair no.. Justamente o contrário dessa tecnologia afastar a criança do pedagógico e tal. Lá onde eu trabalho, não é bem planejado, as crianças só recebem o Ipad, nós professores no início do ano a gente viu aplicativo por aplicativo, estudou, viu qual que tava na perspectiva da escola e tal, aí você pega o Ipad não tem todos os aplicativos que pediu baixado, você pede e quando chega metade tá baixado, metade não tá. E aí a criança acaba se dispersando, porque no dela não tem o aplicativo, tem um joguinho ali do lado, ela vai pro joguinho. Então eu acho que tem que ser muito bem planejado as aulas também, eu acho que o uso da tecnologia tem que ter um objetivo também, não usar por usar, é isso!

PP1: Eu acho que dependendo da idade do aluno acaba que dispersa, tem que ver pra que vai ser usado aquilo, se vai ser usado, porque às vezes pode ser o professor use totalmente a favor dos alunos, ou pode usar contra, usar uma coisa que... nada a ver.

PP6: É positivo se usado com um fim né, porque você pegar levar os alunos pra sala de informática e deixar lá, sem propósito, Deus dará sem um propósito não adianta nada, igual você tem um objetivo pra atingir naquilo ali.

PP2: Agora se você não for preparado e não souber trabalhar, essa tecnologia ela não vai ajudar em nada no aprendizado, no desenvolvimento e nem na construção de conhecimento do aluno, vai ser só mais uma ferramenta que não vai ser bem utilizada.

PP2: Se for bem planejado não tem um ponto negativo, mas sem ser bem planejado pode fugir do controle do docente, e aí toda aquela intencionalidade né, de construção do conhecimento ela vai passar a ser outra coisa.

PP5: Eu acho que depende né, tudo é relativo, depende de como os professores estarão usando isso né. Eu acho que quando é usado a favor deles, a favor dos alunos né, pra uma aprendizagem mais completa eu acho que é importante sim, essa inserção.

Quanto à utilização das TDICE em sala de aula, mediante a percepção dos alunos participantes da pesquisa se percebe que não houve quem fosse contra a utilização desses dispositivos tecnológicos. Todos os alunos foram favoráveis à inserção das TDICE em sala de aula com fins de aprendizagem. Percebe-se que parte dos alunos citou algumas restrições quanto ao emprego. Em se tratando das restrições, foram levantadas em relação à idade dos alunos, à parte financeira (aquisição de 
equipamentos), à intensidade da utilização (não ficar preso somente às tecnologias) e ao planejamento pedagógico (as atividades precisam ser planejadas pedagogicamente para que possam agregar valor ao ensino/aprendizagem). Na opinião dos alunos, a inserção das TDICE na sala de aula propicia a possibilidade de trabalhar atividades lúdicas, sair das aulas maçantes (quadro e giz), preparar o aluno para o mercado de trabalho, possibilidades como suporte às aulas e são ferramentas que auxiliam na acessibilidade de alunos com necessidades especiais.

A postura e atuação do professor em sala de aula vão ser determinantes para o sucesso de um projeto de ensino/aprendizagem com as TDICE. Torna-se muito importante sua formação inicial e uma contínua atualização. No entanto, o professor não deverá estranhar se, porventura, o aluno chegar a dados ou informações que ele próprio ainda não possua. Seu papel não é o de saber tudo o que existe sobre um assunto antes do aluno, mas estar aberto para aprender também com as novas informações descobertas por esse aluno e, principalmente, estar em condições de discutir e debater as informações com ele, bem como ajudá-lo a desenvolver sua criticidade diante do que venha a encontrar (MASETTO, 2013, p. 163).

\subsection{Docência Mediada pelas TDICE}

O avanço do mundo digital traz inúmeras possibilidades, ao mesmo tempo em que deixa perplexas as instituições sobre o que manter, o que alterar, o que adotar. Não há respostas simples. É possível ensinar e aprender de muitas formas, inclusive da forma convencional. Há também muitas novidades, que são reciclagens de técnicas já conhecidas. Não são os recursos que definem a aprendizagem, são as pessoas, o projeto pedagógico, as interações, a gestão. Mas não há dúvida de que o mundo digital afeta todos os setores, a forma de produzir, de vender, de comunicar-se e de aprender. Tudo o que for previsível será cada vez mais realizado por aplicativos, programas, robôs. Nosso papel fundamental na educação escolar é de ser mediadores interessantes, competentes e confiáveis entre o que a instituição propõe em cada etapa e o que os alunos esperam, desejam e realizam (MORAN, 2013, p. 11 - 12). 
Segundo Moran, a cultura digital se expande pela nossa sociedade trazendo consigo a digitalização que proporciona uma grande quantidade de possibilidades de escolha, de interação. O mundo físico se reproduz em plataformas digitais e todos os serviços começam a poder ser realizados física ou virtualmente. Há um diálogo crescente, muito novo e rico entre o mundo físico e o chamado mundo digital, com suas múltiplas atividades de pesquisa, de lazer, de relacionamento e outros serviços e possibilidades de integração entre ambos, que impactam profundamente a educação escolar e as formas de ensinar e de aprender a que estamos habituados. $\mathrm{O}$ avanço científico e tecnológico de nossa sociedade produz muitas mudanças que se refletem na educação escolar. Segundo Gomez (2010, p. 9),

\footnotetext{
As mudanças que estão acontecendo na sociedade, mediadas pelas tecnologias em rede, são de tal magnitude que implicam a médio prazo - em reinventar a educação como um todo, em todos os níveis e todas as formas.
}

Para Oliveira, Nunes e Dos Santos (2012, p. 100), transformar a educação e produzir uma nova profissionalização docente é tarefa social, coletiva, que envolve o Estado, os docentes e toda a sociedade. Não obstante, as TICs não vêm substituir nem tirar a importância da Pedagogia, dos docentes ou de sua formação; pelo contrário, vêm reforçar sua necessidade. O novo perfil e o novo papel docente que o sistema escolar requer devem articular antigas e novas necessidades de aprendizagem docente, entre as quais a própria administração das TICs para fins de ensino e aprendizagem.

Torna-se então primordial a inclusão digital dos alunos na formação de professores. Os conhecimentos e habilidades trabalhadas poderão propiciar a imersão dos futuros professores na sociedade da informação e cultura digital.

Quando se fala em inclusão digital do aluno, não basta que ele aprenda apenas a criar uma apresentação de slides, editar um texto eletrônico, criar um blog ou navegar na internet. A inclusão digital está relacionada com uma profunda mudança social, econômica e cultural do sujeito. Segundo Lacerda Santos (2014, p. 37), a inclusão digital caracteriza-se por uma mudança comportamental e atitudinal, que ocorre no momento em que o sujeito atinge um nível de conhecimento e habilidades que lhe 
permita utilizar, processar e interagir com dados e informações utilizando-se de recursos tecnológicos aliados ao desenvolvimento de competências na área motora, cognitiva e afetiva. Para o autor,

A inclusão digital pode ser considerada como um conjunto de ações permeadas pelas TDICE que possibilitam ao indivíduo que a possui ascender social e economicamente, visto que a posse, a produção e a disseminação da informação podem ser consideradas, à luz desta nova sociedade, as atividades econômicas e sociais primárias.

Sendo assim, não basta apenas ter um conhecimento básico sobre informática e as TDICE. Foi perguntado, em entrevista aos participantes da pesquisa, se eles acreditavam ser possível, mediante formação ofertada no curso de Pedagogia, a inclusão digital do aluno. Os participantes PP1, PP7 e PP10 foram enfáticos ao relatarem em suas falas que não achavam possível o aluno ser incluído digitalmente pelo que foi ofertado a eles em sua formação.

PP1: O meu “currículo" não! Nem um pouco, eu acho que nesse novo que eles criaram também não pensaram muito nisso não.

PP7: Eu acho que não, sinceramente eu acho que não é capaz não.

PP10: Da faculdade não, mas eu acho assim, que a pessoa deve procurar pra auxiliar, eu acho que é uma fermenta que pode conciliar né com a formação, eu acho que ajuda.

Os participantes PP3 e PP5 acreditam que conseguiram obter um certo conhecimento, mas apresentam dúvida se realmente a formação ofertada possibilita a inclusão digital do aluno.

PP3: Eu acho que sim, é suficiente. Agora se isso é ter qualidade ou não, aí já fica a dúvida, mas que é suficiente é, que a gente além de ter algumas obrigatoriedades como o Moodle, e-mail, todos os professores hoje usam algum tipo de tecnologia, WhatsApp, videoaula né, plataforma de ensino, então eu acho que a própria prova que a gente faz ou digitaliza ele tá trazendo de um meio, ter assim então, eu acho que própria assim, minimamente propicia, agora se qualidade é boa ou ruim aí...

PP5: Totalmente não, eu acho que pela disciplina que eu fiz de vídeo, teve outra disciplina também que eu ainda tive que fazer um vídeo, eu acho que na verdade foi bem sofrido assim aprender isso. Porque como a gente não tinha uma orientação a mais sobre, então a gente teve que buscar por si só. Então eu acho que podia ser mais completo isso, eu acho que podia ter 
disciplinas assim, e não só disciplinas só sobre isso, eu acho que todas as disciplinas tinham que ter inclusive digital né, então eu acho que é isso.

O aluno PP8 acredita que a formação propiciada não possibilita a inclusão digital do aluno e ainda faz uma ressalva com relação à preparação dos professores para este fim. O entrevistado menciona a preocupação sobre como buscar este conhecimento.

PP8: Ah não, a pessoa tem que se virar com certeza. Mesmo porque se a gente for pensar pela base nem os professores estão capacitados, eles não sabem mexer com todas as ferramentas, eu tô falando de capacidade intelectual ou do conteúdo propriamente dito não, eu tô falando de capacidade de mexer com o sistema, porque eu acho até que isso deve ser uma filosofia da UnB que não deve permitir isso. Mas eu acho que isso tinha que ser revisto.

Neste sentido, é muito importante que as instituições formadoras de professores agreguem a este novo perfil docente habilidades e conhecimentos para lidarem com as TDICE. Foi perguntado aos alunos participantes da pesquisa se eles teriam sido preparados para lidarem, enquanto professores, com as TDICE em seu trabalho (Gráficos 45 e 46). A maioria dos alunos do curso presencial (cinquenta e sete vírgula sete por cento, $57,7 \%$ ) e também do curso a distância de Pedagogia (quarenta e cinco vírgula cinco por cento, 45,5 \%) assinalaram que a formação ofertada possibilitou a eles terem conhecimentos básicos para lidarem com as TDICE.

Em relação ao curso presencial (Gráfico 45), quarenta vírgula quatro por cento $(40,4 \%)$ dos participantes afirmaram não terem sido preparados para lidarem com as TDICE como professores. Dado muito importante de ser observado, uma vez que vivemos na era da informação. Não preparar o seu aluno para o que irá encontrar fora da universidade acaba sendo uma incongruência, um conhecimento negligenciado em sua formação. Apenas um vírgula nove por cento dos alunos afirmou ter conseguido obter, na sua formação, conhecimentos além do básico para lidar com as TDICE. 
Gráfico 45 - Formação para as TDICE (Presencial)

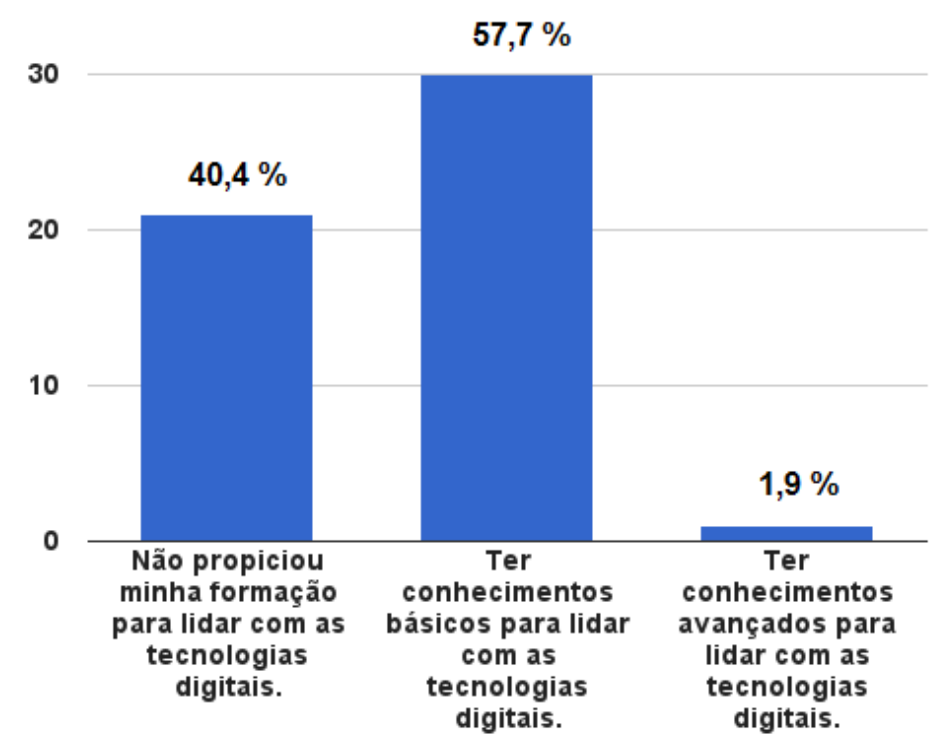

Quanto aos alunos do curso a distância de Pedagogia (Gráfico 46), vinte e sete vírgula três por cento $(27,3 \%)$ dos participantes assinalaram não terem sido formados para lidarem com as tecnologias como docentes e vinte e sete vírgula três por cento $(27,3 \%)$ dos alunos afirmaram ter tido uma formação que lhes possibilitou ter conhecimentos além do básico para utilizarem as TDICE como professores.

Gráfico 46 - Formação para as TDICE (EAD)

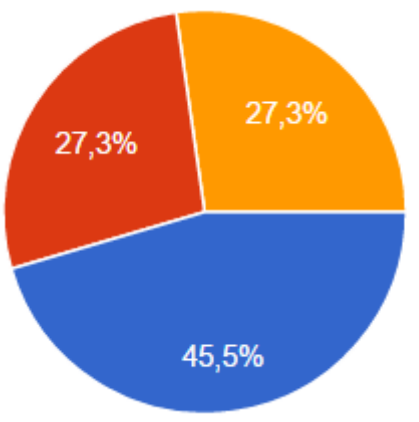

Ter conhecimentos básicos para lidar com as T.D. $\quad 10 \quad 45.5 \%$

Ter conhecimentos avançados para lidar com as T.D. $\quad 6 \quad 27.3 \%$

Näo propiciou minha formaçäo para lidar com as T.D. $\quad 6 \quad 27.3 \%$

Em se tratando dos conhecimentos para trabalhar com as TDICE como professor, alguns trechos das entrevistas ilustram o que pensam os alunos participantes da pesquisa. Os participantes da pesquisa PP1 e PP2 relatam que tiveram uma formação muito deficiente para lidarem com as TDICE. Eles afirmam que não foram preparados para lidarem com as tecnologias de forma pedagogicamente planejada dentro de sala de aula. 
PP1: Não! Nenhum eu acho... (risos). Muito deficiente, é o que eu falei mesmo assim, pra formação mesmo o que a gente sabe assim de mídias é o que a gente já sabe mesmo, que o professor mesmo ele num possibilita isso pra gente, ele só joga o que a gente tem que fazer e cada um por si. Então assim, em sala de aula mesmo eu acho que é complicado, eu como formada chegar numa sala de aula e usar com os alunos talvez seja complicado por conta disso, a não ser que eu estude antes por conta própria minha, mas pela formação que eu tive não...

PP2: É, propicia um conhecimento básico assim, num acho que aluno vai saber fazer o uso sozinho, sabe, sair daqui dizendo: olha eu vou saber montar uma aula, fazer um planejamento que inclua mídia social dentro de sala de aula, não, eu acho.

Para que as TICs possam trazer alterações no processo educativo, no entanto, elas precisam ser compreendidas e incorporadas pedagogicamente. Isso significa que é preciso respeitar as especificidades do ensino e da própria tecnologia para poder garantir que o seu uso, realmente, faça diferença. Não basta usar a televisão ou o computador, é preciso saber usar de forma pedagogicamente correta a tecnologia escolhida (KENSKI, 2012, p. 46). Sem o planejamento adequado o projeto de ensino com as TDICE tende a não ter o retorno esperado: a "aprendizagem dos alunos". A inserção das tecnologias dentro da sala de aula, sem ter um propósito pedagógico definido, pode inclusive atrapalhar o andamento das atividades escolares.

Os participantes da pesquisa PP3, PP4 e PP6 assinalaram que acreditam que a formação ofertada lhes possibilitou ter um conhecimento básico para lidarem com as TDICE. Quando falam em conhecimento básico se referem à habilidade de criar uma apresentação de slide, navegar na internet, utilizar o editor de texto e outras aplicações que desenvolveram enquanto alunos.

PP3: Bem básico assim, básico, menos que o básico.

PP4: Abaixo do básico, (risos), o básico total.

PP6: Eu acho que vai possibilitar o básico.

O entrevistado PP5 acredita que a formação ofertada possibilita ao aluno ter conhecimento básico e ele faz uma crítica ao currículo do curso de Pedagogia. Para o participante, o currículo do curso está desatualizado e ele não se sente preparado para 
lidar com seu público-alvo de trabalho, que seriam as crianças. Ele ressalta ainda a diferença de habilidades para lidar com as tecnologias em relação às crianças.

PP5: Eu acho que o básico, o currículo tá bem desatualizado, as crianças hoje elas parecem que já nascem sabendo mexer em tablete, (risos), celular, computador e vejo pelos os meus irmãos mesmo, eles, meus alunos, eles sabem mexer mais do que eu né, geralmente, então eu acho que tá bem desatualizado, eu acho que a gente tinha que dominar pelo menos né, ser mediano aí pra tá atendendo esse público.

Gomes, Silva e Nunes (2013, p. 69 - 71) alertam que o professor que não teve a possibilidade de aprender com e sobre o uso das TICs em sua formação tem dificuldades em lidar com essa nova modalidade de ensino permeada por essas tecnologias. O docente sem base sólida na sua formação cultural, científica e pedagógica não tem tranquilidade e firmeza para ensinar com os conhecimentos exigidos para os padrões da sociedade contemporânea. Estes alunos que relatam ter uma defasagem de conhecimento e habilidades para lidarem com as TDICE em relação aos seus alunos enfrentarão problemas na sua prática docente.

Já o entrevistado PP8 relata que o curso não proporciona a formação do aluno para lidar com as TDICE. Ele relata uma experiência em outro ambiente onde havia uma preparação do aluno para lidar com as ferramentas tecnológicas e ressalta que no curso ofertado pela UNB isso não foi oportunizado.

PP8: Eu acho que não assim, por exemplo aqui na (...), eu não lembro disso nesse curso, mas aqui por exemplo, quando a gente começa um curso novo, a gente tem encontro presencial de dois dias, aí a gente mostra ferramenta por ferramenta, e antes disso a gente passou tipo uma semana inteira fazendo curso, quem não tem, quem não sabe lidar com educação a distância, a gente passa a semana inteira fazendo pra poder mexer com todo o sistema, depois poder trabalhar na EaD e eu não vi isso na UnB não.

Segundo Lacerda Santos (2010, p. 16), a educação mediada por tecnologias, apesar de vir surgindo gradativamente como prática pedagógica há várias décadas, é ainda uma abordagem extremamente inovadora na sala de aula e no trabalho docente, constituindo um importante desafio para formadores de formadores, para os professores em sala de aula e para os responsáveis por políticas públicas para o setor. 
É responsabilidade das organizações que elaboram e desenvolvem as políticas públicas de formação de professores avançar e ajudar os docentes de forma proativa na constituição de um novo perfil e um novo papel profissional. Essa é uma exigência da sociedade, da escola e dos alunos, independentemente da existência ou não de uma proposta oficial de reforma da educação. Oliveira, Nunes e Dos Santos (2012, p. 105) compreendem que a formação de professores para o uso das TICs implica redimensionar o papel que o professor deverá desempenhar na formação do cidadão do século XXI. Significa introduzir mudanças no ensino-aprendizagem e, ainda, nos modos de estruturação e funcionamento da escola e de sua relação com a comunidade.

Lévy (2010, p. 160) observa que o essencial se encontra em um novo estilo de Pedagogia, que favorece ao mesmo tempo as aprendizagens personalizadas e a aprendizagem coletiva em rede. Para o autor, nesse contexto o professor é incentivado a tornar-se um animador da inteligência coletiva de seus grupos de alunos em vez de um fornecedor direto de conhecimentos. $\mathrm{O}$ autor, ao elucidar a atuação docente, acredita que

Sua competência deve deslocar-se no sentido de incentivar a aprendizagem e o pensamento. O professor torna-se um animador da inteligência coletiva dos grupos que estão a seu encargo. Sua atividade será centrada no acompanhamento e na gestão das aprendizagens: o incitamento à troca dos saberes, a mediação relacional e simbólica, a pilotagem personalizada dos percursos de aprendizagem etc. (LÉVY, 2010, p. 173).

A educação terá como desafio tentar se adaptar aos avanços científicos e tecnológicos e também a orientar o caminho de todos para o domínio e a apropriação crítica desses novos meios, conforme salienta Kenski (2012, p. 18). Foi perguntado aos alunos participantes da pesquisa se eles se sentiam preparados mediante a formação ofertada para uma docência mediada pelas TDICE. Quanto aos participantes do curso presencial (Gráfico 47), quarenta e seis vírgula dois por cento (46,2 \%) assinalaram que foram preparados para uma docência mediada pelas TDICE. Para quarenta vírgula quatro por cento $(40,4 \%)$ dos alunos o curso não possibilitou sua formação para lidar com as tecnologias nas salas de aulas e treze vírgula cinco por cento $(13,5 \%)$ dos participantes não souberam responder se seriam capazes de propiciar uma docência mediada pelas TDICE. 
Gráfico 47 - Docência Mediada pelas TDICE (Presencial)

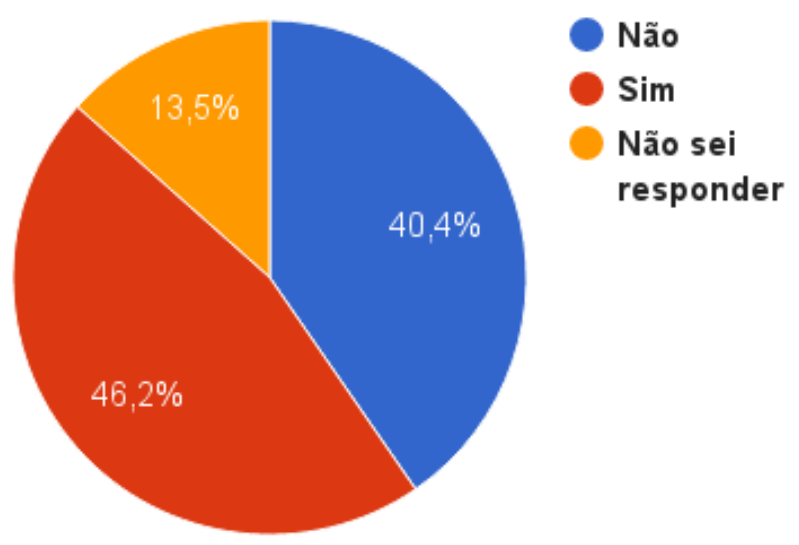

Quanto aos participantes do curso a distância de Pedagogia (Gráfico 48), setenta e sete vírgula três por cento $(77,3 \%)$ afirmaram que foram preparados para uma docência mediada pelas TDICE. Treze vírgula seis por cento $(13,6 \%)$ dos alunos assinalaram que não se sentem preparados para uma docência mediada pelas tecnologias e nove vírgula um por cento $(9,1 \%)$ dos participantes disseram não saber responder.

Gráfico 48 - Docência Mediada pelas TDICE (EAD)

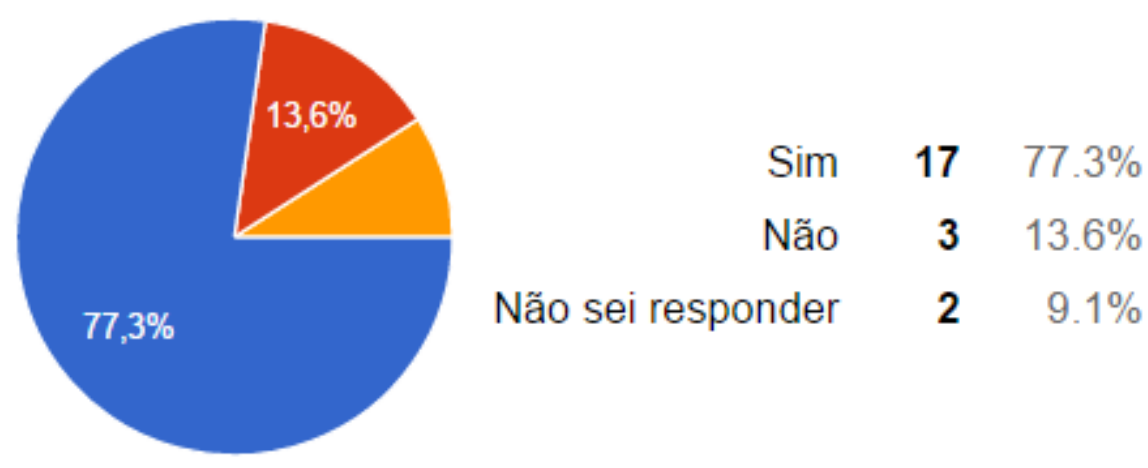

Observa-se que temos dados diferentes em relação à modalidade de ensino do aluno. Conforme a modalidade estudada obteve-se dados acentuando uma resposta ou outra no questionário de pesquisa. A maioria dos alunos do curso presencial demonstrou, por meio do questionário de pesquisa, que não se sentem preparados para uma docência mediada pelas TDICE ou não sabem responder, enquanto que a maioria dos alunos participantes da pesquisa do curso a distância afirmaram que se sentiam preparados para a utilização das TDICE em sala de aula. 
O entrevistado PP7 expressa que será capaz, sim, de desenvolver uma docência mediada pelas TDICE mediante os ensinamentos ao quais teve acesso para trabalhar com as mídias. Conforme dados levantados na pesquisa, a disciplina de mídias foi uma das poucas iniciativas na Faculdade de Educação que possibilitavam ao aluno aprender práticas educacionais envolvendo as TDICE.

PP7: Eu acho que as mídias sim, principalmente a matéria que eu fiz, porque eu aprendi a utilizar as mídias na sala de aula, e toda essa discussão na contemporaneidade nas mídias e de como o aluno de hoje aprende. Eu acho que eu vou ser capaz sim.

Entretanto, há vários trechos de entrevistas que ilustram a dificuldade dos alunos do curso presencial para a prática de uma docência mediada pelas tecnologias. $\mathrm{O}$ aluno PP2 relata que o egresso do curso saberá lidar com operações básicas com as ferramentas tecnológicas. Ressalta que o aluno não terá os conhecimentos necessários para fazer uma integração das ferramentas e nem saberá planejar o uso pedagogicamente, o que lhe renderia uso de toda a potencialidade que essas ferramentas têm.

PP5: Ah eu acho que não, pelo despreparo mesmo, pela formação ser incompleta. Mas eu acho que eu sempre vou buscar aprender né, acho que aprimorar minhas aulas assim.

PP2: Não, ele vai saber usar no sentido básico da coisa sabe?! Ele não vai saber fazer uso de toda a potencialidade que essas ferramentas têm, mas o básico. Como fazer o uso de um PowerPoint, ou talvez pensar numa aula que fizesse o uso de um blog, fizesse o uso de uma mídia social, mas não fazer isso tudo integrado sabe?! Fazer um planejamento pensando no uso de todas essas mídias, e sempre!

O aluno PP4 relata uma experiência profissional que aconteceu com ele ilustrando a falta de preparo para lidar com as TDICE dentro da sala de aula com propósito pedagógico. O entrevistado descreve que acreditava que não sentiria dificuldade para lidar com as tecnologias, até que se deparou com uma situação onde eram necessários os conhecimentos para uma docência mediada pelas tecnologias. Foi relatado por ele que teve que fazer o curso no trabalho para ter um bom desenvolvimento com as ferramentas tecnológicas. 
PP4: Não, e eu passei por isso, porque agora esse ano na escola que eu trabalho na rede de uma turminha de maternal, eu achei que não ia sofrer tanto assim, porque eram crianças muito pequeninhas e tal, mais você não... eu não sabia ligar a AppleTV, não sabia algumas ferramentas da Apple do Ipad tal. E essa questão também que eu tinha falado de planejamento porque você acha que é só mexer com o tablet, dá o tablet pra criança e não é bem assim. Até pra você ensinar mesmo uma coisa que você não sabe pro outro é muito complicado, então a gente tinha que ter essa formação, os cursos nesse sentido nessa área. [...] se não fosse o curso que eu recebi lá no meu trabalho, eu não saberia mexer de forma alguma.

O participante PP7 menciona que teve contato com as TDICE somente enquanto aluno. Não saberá planejar uma aula para utilizar tais dispositivos tecnológicos como professor com seus alunos. Não houve a preocupação no curso de ensinar os alunos a como proceder e ter habilidades para mediação das tecnologias na escola.

PP7: Não, a gente usa muito o Moodle aqui em algumas disciplinas, e até como usar o Moodle mesmo a gente não é ensinado, a gente vai aprendendo sozinho com o Moodle. Se a gente está sendo formado como professor, não vai poder utilizar o Moodle um dia na sua escola, a gente não sabe utilizar o Moodle como o professor acessa, só utilizamos como aluno.

Os entrevistados PP3 e PP6 mencionam a preocupação que os alunos devem ter com o conhecimento para lidar com as tecnologias e realçam a importância em se buscar as habilidades e conhecimentos para não ficarem despreparados. O aluno PP3 descreve que o currículo como proposto não propicia os ensinamentos para uma docência mediada pelas tecnologias, mas relata que o aluno pode procurar se capacitar procurando, na universidade, iniciativas dessa natureza. $\mathrm{O}$ aluno ainda relata que as oportunidades são escassas. Já o entrevistado PP3 diz se sentir preparado para lidar com as TDICE nas salas de aulas por ter buscado um conhecimento e habilidades em cursos fora da graduação. Ele relata que com o ensinado na faculdade não se sentiria confortável para desenvolver uma docência mediada pelas tecnologias.

PP3: Oh, eu acho como tá proposto no currículo não, mas como o aluno da UnB tem muita autonomia e possibilidades, se ele procurar dentro da UnB ele consegue, aí vai depender de cada um, que eu já consigo como uma formação, como responsabilidade da formação do aluno, vai depender muito dele, mas não é uma coisa dada, obrigatória ou exigida como outra disciplina. [...] vai ter que procurar aí, e é concorrido também, porque tem pouco. 
PP6: Se eu não buscar um conhecimento, fora, externo não! Eu me sinto preparada porque eu aprendi fora, mas se fosse depender do que eu aprendi aqui dentro não. Eu me sinto confortável porque eu aprendi fora, eu aprendi a mexer fora, mas aqui da universidade não.

Percebe-se pelas respostas das entrevistas que muitos alunos do curso a distância de Pedagogia também apresentam dificuldades para uma docência mediada pelas TDICE, indo contra o que foi assinalado no questionário. Talvez pelo fato de estudarem em uma modalidade de ensino em que a tecnologia se faz presente, com contato constante com a informática, internet e TDICE. Os entrevistados PP8 e PP10 ilustram a dificuldade para a prática de uma docência mediada pelas TDICE por parte dos alunos do ensino a distância. Ao serem questionados se estariam preparados para mediação com essas tecnologias, afirmaram o seguinte:

\section{PP8: Eu acho que não!}

PP10: Assim, lógico que você vai ter uma facilidade a mais, se você tem uma qualificação a mais. Mas acredito que só por fazer uma faculdade já consegue né, um aproveitamento sim dessas tecnologias.

Com base na percepção dos participantes da pesquisa pode-se observar que grande parte dos alunos julgou que a formação ofertada pelo curso de Pedagogia não propicia a inclusão digital do aluno e que eles conseguiram obter apenas um conhecimento básico para lidarem com as TDICE. Observa-se também uma grande quantidade de alunos afirmando que não foram preparados para trabalharem com as TDICE. Quando falamos de uma atividade docente mediada pelas TDICE, foi apurado perante aos alunos que muitos afirmaram que não serão capazes de implementar na prática uma didática com as TDICE de forma pedagogicamente planejada.

Foi relatado que o currículo não proporciona ensinamentos para desempenho da docência em uma mediação com as tecnologias. E apesar de a pesquisa com os alunos do curso a distância de Pedagogia realizado por meio dos questionários resultar no fato de que a maioria dos alunos estariam preparados para utilizarem as TDICE em mediação em sala de aula para propiciar a aprendizagem, analisando as entrevistas pode-se perceber que alguns alunos se sentiram inseguros quanto à capacidade de planejar pedagogicamente atividades com as TDICE e desenvolvê-las em uma mediação pedagógica. 
Torna-se muito importante ter um profissional preparado para saber guiar seus alunos pelo emaranhado de novidades e inovações tecnológicas que existem e surgem a cada dia. O professor tem esse papel de orientar os seus alunos sobre como proceder e utilizar as tecnologias dentro e fora da sala de aula. Kenski (2012, p. 107) salienta a importância de se ter um profissional qualificado. Ela relata que se a ênfase do processo de tecnologização da sociedade recai na importância da educação, a importância de educadores bem qualificados e reconhecidos profissionalmente torna-se condição primordial de ação. Uma política de pessoal que reconheça e valorize suas competências e importância, com o oferecimento de cursos de aperfeiçoamento e de atualização, além de uma formação inicial de qualidade, um projeto de carreira consistente, a melhoria de condições de trabalho e de vida são fundamentais para que os professores possam atuar com qualidade.

\section{CONSIDERAÇÕES FINAIS}

A escola vem passando por diversas transformações em sua constituição e forma de atuação mediante as mudanças ocorridas em nossa sociedade. Ela precisa acompanhar as transformações desencadeadas em uma sociedade que vive em mutação. A escola tem que estar aberta à sociedade e agir de forma pensante, ter flexibilidade, possibilitar a interatividade, atualização e contextualização para atender às mudanças no papel do aluno que sai de mero expectador, ser passivo, passando a gerir e a relacionar informações para que possa transformar o seu saber e conhecimento.

Um grande desafio do professor é baseado na criação de formas de possibilitar a seus alunos vislumbrar referências presentes no seu cotidiano, vizinhança e mundo. Deve assumir e estabelecer sua ampliação, passando assim a ser um sujeito ativo na transformação e mudança de seu contexto. O aluno necessita sair da passividade e passar a atuar em uma nova dimensão, podendo romper com a transmissão de conteúdos de forma vertical e somente em uma direção, criando assim um processo de participação de forma autônoma e preparado para se desenvolver na sociedade criticamente como um cidadão. 
A meta a ser alcançada pela educação está substanciada na difícil tarefa de tirar o foco central da aprendizagem do professor e repassá-lo ao aluno. Enquanto o professor for entendido como elemento central do processo ensino-aprendizagem haverá alunos que terão seus mundos social, político, curricular, pedagógico reduzidos e cerceados pela atuação do professor. A função que o professor vai desempenhar na escola é muito importante para que consigamos mudar esta cultura da passividade assumida pelos alunos e também para que possamos produzir sujeitos com autonomia intelectual pautados na reflexão e na crítica.

O professor precisa estar preparado para os novos e crescentes desafios desta geração que nunca esteve tão em contato com novas tecnologias e fontes de acesso ao conhecimento. $\mathrm{O}$ trabalho do professor é muito desafiador e extremamente complexo. $\mathrm{O}$ docente necessita ter uma formação inicial sólida e também uma permanente complementação e atualização profissional por meio da formação continuada. $\mathrm{O}$ foco da formação dos professores deve ser mais em processos geradores da aprendizagem de seus alunos do que no ensino transmissivo de conteúdos. Além disso, deve privilegiar o aprender a aprender, garantindo aos docentes ferramentas intelectuais e emocionais para se adaptarem aos contextos em mudança.

Vários segmentos de nossa sociedade imergiram nessa onda revolucionária e tecnológica da cultura digital. O que não acontece com tanta facilidade quando falamos da educação. Sabe-se que a aproximação da educação com as TDICE se faz de forma lenta e gradativa, de uma forma até indisciplinada, quando as tecnologias pulam os muros das escolas e adentram o ambiente educacional por meio dos alunos.

A presente pesquisa objetivou estudar um aspecto muito importante envolvendo os avanços científicos e tecnológicos e a difusão destes conhecimentos na sociedade. Com a pesquisa pode ser estabelecido um diagnóstico da formação do pedagogo no curso de Pedagogia da UNB de forma que foi possível indicar, mediante a percepção dos alunos do curso, aspectos que julgam ser importantes para uma melhor formação na temática estudada. Trata-se de agregar valor ao curso que já é muito bem conceituado. Olhar com maior atenção para as mudanças em nossa sociedade e para o que se passa fora da escola. 
$\mathrm{Na}$ pesquisa foram analisadas algumas variantes importantes para determinar se o curso de Pedagogia ofertado pela Universidade de Brasília possibilita a inclusão digital do seu aluno oportunizando assim uma docência mediada pelas TDICE aos futuros professores. Para tanto, foi feito um estudo em relação à infraestrutura tecnológica e digital disponível aos graduandos; às oportunidades curriculares ofertadas para a formação e entendimento dos alunos sobre a temática "Educação e Tecnologias"; à postura e didática dos professores do curso em relação às TDICE; sobre a percepção dos alunos mediante a inserção das TDICE em sala de aula e também sobre o preparo do futuro professor do curso de Pedagogia para proporcionar uma docência mediada pelas TDICE com seus alunos.

Observa-se que a Faculdade de Educação disponibiliza aos seus alunos como suporte ao curso de Pedagogia diversos dispositivos e ferramentas tecnológicas. Percebe-se, pela pesquisa, que a FE oportuniza aos seus alunos o acesso a computadores, internet e dispositivos tecnológicos que podem ser utilizados por eles para a realização de atividades curriculares e também em aulas. Vale ressaltar que essa infraestrutura ofertada sofreu muitas críticas. Quanto aos computadores, a quantidade, a conservação, a atualização e o ambiente foram questionados. Quanto à internet, a qualidade do acesso (link lento), o alcance do link que não funcionava em todos os prédios. Quanto aos dispositivos tecnológicos e digitais, a quantidade disponível para utilização, estado de conservação e condição de agendamento.

Percebe-se então que a FE vem disponibilizando uma infraestrutura que na opinião dos alunos participantes da pesquisa ainda precisa ser melhorada para um melhor aproveitamento e suporte aos graduandos no curso. Muitos alunos relataram não possuir computadores, internet e dispositivos tecnológicos que pudessem utilizar em sua residência e que a FE ajudaria muito em sua formação se disponibilizasse em qualidade e quantidade suficiente tais dispositivos para sua familiarização e desenvolvimento de suas atividades no curso de Pedagogia.

Foram oportunizadas aos alunos opções curriculares para que eles pudessem obter o conhecimento sobre elementos formativos para o manuseio de ferramentas de desenvolvimento de materiais didáticos. A principal opção apontada foi por meio de disciplinas do curso. Percebe-se que estas disciplinas receberam muitas críticas com 
relação ao aprofundamento do conteúdo estudado e falta de infraestrutura para desenvolvimento na disciplina. Alguns alunos abandonaram disciplinas pelo fato de a qualidade não estar sendo satisfatória. Em relação aos conteúdos disciplinares referentes à compreensão da Sociedade Informacional e de seus impactos na organização do trabalho pedagógico, apesar de muitos alunos terem respondido que cursaram disciplinas sobre esta temática, pode-se observar pelas entrevistas que não tiveram uma disciplina que abordasse de forma mais aprofundada a temática.

Pelos relatos pode ser percebido que alguns conceitos foram trabalhados de forma superficial em disciplinas optativas. Alguns entrevistados sugeriram que o currículo deveria ser atualizado para condizer com as mudanças sociais, culturais, econômicas de nossa sociedade. Algumas das sugestões foram: a inclusão de oficinas para trabalhar com os dispositivos digitais, mais disciplinas sobre a temática, alguns inclusive apontaram que seria interessante que esta disciplina fosse obrigatória, além de ensinamentos para aprender a utilizar de forma pedagogicamente planejada as TDICE em sala de aula para propiciar a aprendizagem.

Quando falamos em experiência concreta em aprendizagem mediada pelas tecnologias, foi constatado que muitos alunos alegaram que tiveram muito pouco contato em sua graduação. Alguns alunos alegaram que tiveram contato com as tecnologias apenas como alunos, mas não tinham conhecimento para utilizar a ferramenta tecnológica como professor. Também alguns alunos afirmaram ter tido experiência em aprendizagem mediada pelas tecnologias, mas estes em número muito pequeno em relação à totalidade de alunos participantes da pesquisa. Além de que, foram muito poucas iniciativas dessa natureza oportunizadas aos graduandos. Percebese pela pesquisa que os alunos tiveram contato com as TDICE na graduação em diferentes situações, seja para utilização como meio de comunicação, seja em sala de aula ou fora, para realização de trabalhos escolares, etc.

Percebe-se que grande parte dos professores fazem uso das tecnologias em sua prática docente, mas houve muitos questionamentos dos alunos em relação à forma com que estes professores empregavam a tecnologia em sala. Relataram que muitos dos professores tinham dificuldades em lidar com as tecnologias, alguns até proibiam o uso, outros não sabiam utilizar ou não proporcionavam ensinamentos para que os alunos 
pudessem aplicar na prática como futuros professores. Foi demonstrada, por uma grande quantidade de alunos, a preocupação em estarem bem preparados para atuar com crianças que já nascem imersas na cultura digital. Vários alunos acabaram procurando fazer cursos fora da graduação pelo fato de não sentirem preparados para a atuação docente com as tecnologias digitais dentro de sala de aula.

Quanto à utilização das TDICE em sala de aula, mediante a percepção dos alunos participantes da pesquisa pode ser observado que não houve quem fosse contra a utilização desses dispositivos tecnológicos. Todos os alunos foram favoráveis à inserção das TDICE em sala de aula com fins a aprendizagem. Percebe-se que parte dos alunos citaram algumas restrições quanto ao emprego. Em se tratando das restrições, foram levantadas em relação à idade dos alunos, à parte financeira (aquisição de equipamentos), à intensidade da utilização (não ficar preso somente às tecnologias) e ao planejamento pedagógico (as atividades precisam ser planejadas pedagogicamente para que possam agregar valor ao ensino/aprendizagem). Na opinião dos alunos, a inserção das TDICE na sala de aula propicia a possibilidade de trabalhar atividades lúdicas, sair das aulas maçantes (quadro e giz), preparar o aluno para o mercado de trabalho, possibilidades como suporte às aulas e são ferramentas que auxiliam na acessibilidade de alunos com necessidades especiais.

Com base na percepção dos participantes da pesquisa pode-se observar que grande parte dos alunos julgou que a formação ofertada pelo curso de Pedagogia não propicia a inclusão digital do aluno e que eles conseguiram obter apenas um conhecimento básico para lidarem com as TDICE. Observa-se também uma grande quantidade de alunos afirmando que não foram preparados para trabalharem com as TDICE. Quando falamos de uma atividade docente mediada pelas TDICE, foi apurado que muitos alunos afirmaram que não serão capazes de implementar na prática uma didática com as TDICE de forma pedagogicamente planejada. Foi relatado que o currículo não proporciona ensinamentos para o desempenho da docência em uma mediação com as tecnologias. E apesar do estudo com os alunos do curso a distância de Pedagogia realizado mediante os questionários resultar que a maioria dos alunos estariam preparados para utilizarem as TDICE em mediação em sala de aula para propiciar a aprendizagem, quanto à análise das entrevistas pode-se perceber que alguns 
alunos se sentiram inseguros quanto à capacidade de planejar pedagogicamente atividades com as TDICE e desenvolvê-las em uma mediação pedagógica.

As poucas oportunidades curriculares, a infraestrutura regular e a baixa propagação dos conceitos e conhecimentos pelos professores do curso em relação à temática estudada tornam muito difícil a aquisição pelo aluno de habilidades e conhecimentos necessários para a formação inicial que permita o desenvolvimento de uma atividade docente mediada pelas TDICE visando à promoção da aprendizagem de seus futuros alunos.

Segundo Moran (2013, p. 36), as TDICE facilitam a pesquisa, a comunicação e a divulgação em rede. A gestão das tecnologias pelas escolas passa por três etapas, até o momento. Na primeira, as tecnologias são utilizadas para melhorar o que já se vinha fazendo, como o desempenho, a gestão, para automatizar processos e diminuir custos. $\mathrm{Na}$ segunda etapa, a escola insere parcialmente as tecnologias no projeto educacional. Cria uma página na internet ou um portal com algumas ferramentas de pesquisa e comunicação, divulga textos e endereços interessantes, desenvolve alguns projetos, algumas atividades no laboratório de informática, introduz aos poucos as tecnologias móveis, mas mantém intocada a estrutura de aulas, as disciplinas e os horários. Na terceira etapa, com o amadurecimento de sua implantação e o avanço da integração das tecnologias móveis, escolas e universidades repensam seu projeto pedagógico, seu plano estratégico, e introduzem mudanças metodológicas e curriculares significativas, como a flexibilização parcial do currículo, com atividades a distância combinadas com as presenciais.

Percebe-se que a Faculdade de Educação, mediante o ofertado para constituição do curso de Pedagogia, se encontra na segunda etapa, pois as TDICE começaram a ser inseridas parcialmente no projeto escolar. Verifica-se que a FE disponibiliza pagina própria na web e sistema de gerenciamento acadêmico, além de disponibilizar o sistema educacional Moodle aos alunos e professores. Algumas atividades são desenvolvidas nos laboratórios de informática, assim como o trabalho com mídias digitais. No entanto, a estrutura das aulas, as disciplinas e os horários de uma forma geral permanecem como tradicionalmente. Deseja-se que a instituição escolar possa atingir a terceira etapa e imergir na cultura digital, realizando assim uma 
discussão sobre o projeto pedagógico e seu plano estratégico para atualização com as mudanças em nossa sociedade.

A Faculdade de Educação, direção e coordenação de curso percebem a importância em haver estudos relacionados com as tecnologias, informação, comunicação e expressão ao passo que já têm implantado na FE uma linha de pesquisa que trate de estudos na temática "ETEC - Educação, Tecnologias e Comunicação". A faculdade disponibiliza dispositivos tecnológicos e digitais, tem iniciativas curriculares para formação dos alunos nesta área, propicia debates sobre a temática e vem investindo em melhorias em sua infraestrutura. Sabe-se que a FE muito ainda tem a melhorar para que os ensinamentos em relação à temática "Educação e Tecnologias" possam ser desenvolvidos com maior qualidade. Pois, segundo Moran ( 2013, p. 71), ensinar com as novas mídias será uma revolução se mudarmos simultaneamente os paradigmas convencionais da educação escolar, que mantêm distantes professores e alunos. Caso contrário, só conseguiremos dar-lhes um verniz de modernidade, sem mexer no essencial.

Percebemos com clareza que as técnicas só poderão colaborar para o desenvolvimento das pessoas quando empregadas numa perspectiva de aprendizagem, em que o aprendiz é o centro do processo, que se realiza num clima de confiança e parceria entre alunos e professor, que também estão imbuídos de uma mesma proposta de aprendizagem cooperativa. O professor assume uma nova atitude. Embora, vez por outra, ainda desempenhe o papel do especialista que possui conhecimentos e/ou experiências a comunicar, o mais das vezes ele vai atuar como orientador das atividades do aluno, consultor, facilitador, planejador e dinamizador de situações de aprendizagem, trabalhando em equipe com o aluno e buscando os mesmos objetivos (MASETTO, 2013, p. 142).

Aprender a decorar um volume infindável de informações tornou-se tarefa de questionável valor, uma vez que pela produção veloz com que os conhecimentos vêm sendo apresentados e renovados eles tendem a envelhecer rapidamente. A visão ingênua do professor que julga ensinar tudo aos alunos sobre sua disciplina passou a ser impraticável, pois o universo das informações se estendeu e se ampliou. Portanto, mais que apresentar e decorar conteúdos, os alunos precisam aprender a acessá-los, a pensar e 
refletir sobre eles. Os professores e os alunos podem utilizar as tecnologias da informação para estimular o acesso à informação e à pesquisa individual e coletiva, favorecendo processos para aumentar a interação entre eles. A rede informatizada cria a possibilidade de exposição e de disponibilização das pesquisas aos alunos, de maneira mais atrativa e produtiva, da demonstração e da vivência de simulação por texto e imagens, facilitando o discernimento e o envolvimento dos alunos com problemas reais da sociedade (BEHRENS, 2013, p. 104).

O presente estudo trata de um dos aspectos envolvidos para analisar se os alunos do curso de Pedagogia estão tendo uma formação que proporcione ensinamentos e conhecimentos para uma docência mediada pelas TDICE. Analisamos tais aspectos pela percepção dos alunos do curso. Outras dimensões também podem ser analisadas para que se possa chegar a um entendimento quanto ao objetivo da pesquisa. Torna-se muito importante sempre a autoavaliação e a atualização dos cursos promotores de formação de professores para manterem sua pertinência e aplicação na sociedade vigente. Recomenda-se que mais pesquisas e discussões possam ser feitas para que o curso de Licenciatura em Pedagogia da Universidade de Brasília continue sendo referência na formação de professores. 
ADAMI, A. Info Escola. Redes Sociais. Disponível em: <http://www.infoescola.com/sociedade/redes-sociais-2/>. Acesso em: 12 fev. 2015.

ALMEIDA, M. E. B. D. Inclusão digita de professor: Formação e prática pedagógica. São Paulo: Editora Articulação Universidade/Escola, 2004.

ARAÚJO, C. Info Escola. O que são blogs? Disponível em: <http://www.infoescola.com/informatica/o-que-sao-blogs/>. Acesso em: 12 fev. 2015.

BARDIN, L. Análise de Conteúdo. Tradução de Luís Antero Reto e Augusto Pinheiro. São Paulo: Edições 70, 2011.

BEHRENS, M. A. Projetos de aprendizagem colaborativa num paradigma emergente. In: MORAN, J. M.; MASETTO, M. T.; BEHRENS, M. A. Novas tecnologias e mediação pedagógica. 21. ed. Campinas: Papirus, 2013.

BELlONI, M. L. O que é mídia-educação. 2. ed. Campinas: Autores Associados, 2005.

BRAGA, C. B.; LACERDA SANTOS, G. Tablets, laptops, computadores e crianças pequenas: novas linguagens, velhas situações na educação infantil. Brasília: Liber Livro, 2012.

BRASIL. Fundo Nacional de Desenvolvimento da Educação. Programa Banda Larga nas Escolas (PBLE). Disponível em: <www.fnde.gov.br/programas/programanacional-de-tecnologia-educacional-proinfo/proinfo-programa-banda-larga-nas-escolaspble>. Acesso em: 6 fev. 2015.

BRASIL. Fundo Nacional de Desenvolvimento da Educação. Tablet Educacional. Disponível em: <www.fnde.gov.br/programas/programa-nacional-de-tecnologiaeducacional-proinfo/proinfo-tablets >. Acesso em: 6 fev. 2015.

BRASIL. Fundo Nacional de Desenvolvimento da Educação. Projeto Um Computador por Aluno (UCA). Disponível em: $<$ www.fnde.gov.br/programas/programa-nacional-de-tecnologia-educacionalproinfo/proinfo-projeto-um-computador-por-aluno-uca>. Acesso em: 6 fev. 2015.

BRASIL. Fundo Nacional de Desenvolvimento da Educação. ProInfo - Programa Nacional de Tecnologia Educacional. Disponível em: $<$ www.fnde.gov.br/programas/programa-nacional-de-tecnologia-educacionalproinfo/proinfo-apresentacao>. Acesso em: 6 fev. 2015.

BRASIL. Lei $n^{\circ}$ 5.540, de 28 de novembro de 1968: Organização e Funcionamento do Ensino Superior. Presidência da República. Disponível em: <http://www.planalto.gov.br/ccivil_03/leis/15540.htm>. Acesso em: 5 jan. 2015. 
BRASIL. Lei $n^{\circ}$ 5692/71, de 11 de agosto de 1971: Diretrizes e Bases para o ensino de $1^{\circ}$ e $2^{\circ}$ graus. Presidência da República. Disponível em: <http://www.planalto.gov.br/ccivil_03/leis/15692.htm>. Acesso em: 5 jan. 2015.

BRASIL. Ministério da Educação. e-Proinfo. Disponível em: $<$ http://portal.mec.gov.br/index.php?option=com_content\&id=138:e-proinfo>. Acesso em: 12 fev. 2015.

BRASIL. Ministério da Educação. Projetor Proinfo. Disponível em: <http://webeduc.mec.gov.br/projetorproinfo/>. Acesso em: 12 fev. 2015.

BRASIL. Ministério da Educação. TV Escola. Disponível em: <http://tvescola.mec.gov.br/tve/about?clearBreadCrumb=true>. Acesso em: 6 fev. 2015.

BRZEZINSKI, I. Faculdade de Educação da UnB: Da utopia ao projeto real. Cadernos Linhas Críticas, Brasília, 3, p. 31 - 48, 1997a.

Formação de professores - um desafio. Goiânia: UCG, 1997b.

ANFOPE. Pesquiseduca, Santos, v. 1, n. 2, p. 151 - 156, 2009.

BUZATO, M. E. K. Letramento Digital abre as portas para o conhecimento. São Paulo: Educarede, 2003.

BUZATO, M. E. K. Entre a fronteira e a periferia: linguagem e letramento na inclusão. Campinas: UNICAMP, 2007.

CARVALHO NUNES, J. B. TDICE, política educacional e formação de professores. In: NUNES, J. B. C.; OLIVEIRA, L. X. D. Formação de professores para as TDICE: software livre e educação a distância. Brasília: Liber Livro, 2012.

CASTELLS, M. A sociedade em rede. 6. ed. São Paulo: Paz e Terra, 1999.

CORPORATION, C. CorelDRAW. Visão Geral - Software de Design Gráfico. Disponível em: <http://www.coreldraw.com/br/product/software-de-design-grafico/>. Acesso em: 12 fev. 2015.

CRESWELL, J. W. Projeto de pesquisa: métodos qualitativo, quantitativo e misto. Tradução de Magda Lopes. 3. ed. Porto Alegre: Artmed, 2010.

DAL-FARRA, R. A.; LOPES, P. T. C. Métodos Mistos de Pesquisa em Educação: Pressupostos Teóricos. Nuances: estudos sobre a Educação, Presidente Prudente, 24, set. 2013.

DEMO, P. Charme da exclusão social. Campinas: Autores Associados, 2002. 
DUFFY, M. E. Methodological Triangulation: a vehicle for merging quantitative and qualitative research methods. Journal of Nursing Scholarship, 19, p. 130-133, 1987.

FERREIRA, C. A. R.; LACERDA SANTOS, G. A inclusão digital em meios de ensino formais e não-formais. Lisboa Pt: Faculdade de Motricidade Humana FMH, 2014.

FERREIRA, M. Inclusão digital de professores da Secretaria de Educação do Distrito Federal: Um estudo sobre a formação docente. 2009. Dissertação (Mestrado em Educação) - Faculdade de Educação, Universidade de Brasília, Brasília, 2009.

FREITAS, M. T. Educ. rev. Letramento digital e formação de professores, Belo Horizonte, 26, dez. 2010. Disponível em: http://www.scielo.br/scielo.php?script=sci_arttext\&pid=S0102-46982010000300017. Acesso em: 16 abr. 2014.

GIL, A. C. Métodos e técnicas de pesquisa social. 6. ed. São Paulo: Atlas, 2008.

GOMES, R. O. D. A.; SILVA, M. L. R. D.; NUNES, J. B. C. Formação de professores para o letramento digital. In: NUNES, J. B. C.; OLIVEIRA, L. X. D. Formação de professores para as TDICE: software livre e educação a distância. Brasília: Liber Livro, v. 2, 2013.

GOMEZ, M. V. Cibercultura, formação e atuação docente em rede: guia para professores. Brasília: Liberlivro, 2010.

GONSALVES, E. P. Conversas sobre iniciação à pesquisa científica. 4. ed. Campinas: Editora Alínea, 2005.

GOOGLE, E. Google Earth. Inicio - Google Earth. Disponível em: <http://www.google.com.br/intl/pt-BR/earth/>. Acesso em: 12 fev. 2015.

HUFF, A. S. Designing research for publication. CA: Thousand Oaks, 2008.

KENSKI, V. M. Educação e Tecnologias: O novo ritmo da informação. 8. ed. Campinas: Papirus, 2012.

KIRSCHBAUM, C. Decisões entre pesquisas quali e quanti sob a perspectiva de mecanismos causais. Revista Brasileira de Ciências Sociais, São Paulo, v. 28, jun. 2013.

LACERDA SANTOS, G. A gestão de relações educativas apoiadas pelo computador por meio da pedagogia de projetos. In: LACERDA SANTOS, G. Tecnologias na Educação e formação de professores. Brasília: Editora Plano, 2003. 
Formar professores para a educação mediada por tecnologias: Elucidação da problemática por meio de seis investigações acadêmicas. In: ANDRADE, J. B. F.; LACERDA SANTOS, G. Virtualizando a escola: migrações docentes rumo à sala de aula virtual. Brasília: Liber Livro, 2010.

A promoção da inclusão digital de professores em exercício: uma pesquisa de síntese sobre aproximações entre professores, novas mídias e manifestações culturais emergentes na escola. Inter Ação, Goiânia, v. 39, 2014.

FERREIRA, M.; CASTRO, W. D. A pedagogia de projetos como estratégia de inclusão digital de professores dos anos iniciais do ensino fundamental. In: FERREIRA, C. A. R.; LACERDA SANTOS, G. A inclusão digital em meios de ensino formais e não-formais. Lisboa Pt: Faculdade de Motricidade Humana FMH, 2014.

; FIRMINO, E. A. D. P. A promoção da inclusão digital de professores: Avaliação de uma política pública brasileira para formação docente. In: FERREIRA, C. A. R.; LACERDA SANTOS, G. A inclusão digital em meios de ensino formais e não-formais. Lisboa Pt: Faculdade de Motricidade Humana FMH, 2014.

; KEMPFER, L. M. D. A. Cibercultura e mediação pedagógica: Estudo acerca da inclusão digital docente. In: FERREIRA, C. A. R.; LACERDA SANTOS, G. A inclusão digital em meios de ensino formais e não-formais. Lisboa Pt: Faculdade de Motricidade Humana FMH, 2014.

LÉVY, P. Cibercultura. 2. ed. São Paulo: Editora 34, 2010.

LIBÂNEO, J. C. Pedagoiga e Pedagogos, para quê? 12. ed. São Paulo: Cortez, 2010.

MARTIN-BARBERO, J. Reconfigurações comunicativas do saber e do narrar. In: MARTIN-BARBERO, J. A comunicação na educação. São Paulo: Contexto, 2014.

MASETTO, M. T. Mediação pedagógica e tecnologias de informação e comunicação. In: MORAN, J. M.; MASETTO, M. T.; BEHRENS, M. A. Novas tecnologias e mediação pedagógica. 21. ed. Campinas: Papirus, 2013.

MASSIAS, S. C. As propostas da associação nacional pela formação dos profissionais da educação (ANFOPE) para a definição do curso de Pedagogia no Brasil (1990 - 2006). São Paulo: Pontifícia Universidade Católica, 2007. 154 p.

MENEZES, T. M. C. C. A Faculdade de Educação da Universidade de Brasília: História de um isolamento. Brasília: UNB, 1989.

MENTA, E. EscolaBR: inclusão digital de professores. Curitiba: UFPR, 2011. 
MITJÁNS MARTÍNEZ, A. A criatividade na escola: três direções de trabalho. Revista Linhas Críticas, Brasília, v.8, n. 15, jul./dez. 2002.

MORAN, J. M. Apresentação. In: GOMEZ, M. V. Cibercultura, formação e atuação docente em rede: guia para professores. Brasília: Liberlivro, 2010.

Ensino e Aprendizagem inovadores com apoio de tecnologias. In: MORAN, J. M.; MASETTO, M. T.; BEHRENS, M. A. Novas tecnologias e mediação pedagógica. 21. ed. Campinas: Papirus, 2013.

NEVES, J. L. Pesquisa Qualitativa - Características, usos e possibilidades. Caderno de Pesquisas em Administração, São Paulo, v. 1, 1996.

NUNES, A. I. B. L.; SILVEIRA, R. D. N.; XAVIER, A. S. Aprendizagem e subjetividade em tempos de tecnologias: desafio à instituição escolar. In: NUNES, J. B. C.; OLIVEIRA, L. X. D. Formação de professores para as TDICE: software livre e educação a distância. Brasília: Liber Livro, 2012.

NUNES, J. B. C. TDICE, política educacional e formação de professores. In: NUNES, J. B. C.; OLIVEIRA, L. X. Formação de professores para as TDICE: software livre e educação a distância. [S.1.]: Liber Livro, v. 1, 2012.

OLIVEIRA, L. X. D.; NUNES, J. B. C.; DOS SANTOS, V. D. P. A. Formação de professores e inclusão digital: $\mathrm{O}$ uso do software livre. In: OLIVEIRA, L. X. D.; NUNES, J. B. C. Formação de professores para as TDICE: software livre e educação a distância. [S.1.]: Liber Livro, v. 1, 2012.

OLIVEIRA, W. L.; $O$ docente do ensino médio e as tecnologias da informação e comunicação: análise de possíveis alterações no processo de trabalho. Dissertação (Mestrado em Educação), Faculdade de Educação, Universidade Federal de Minas Gerais. Belo Horizonte, 2007.

OLIVEIRA, W. L.; As tecnologias da informação e comunicação e a intensificação do trabalho docente. Educação, Formação \& Tecnologias, Lisboa. 3 (1): 84-95. mai. 2010 .

PASSOS, R.; SOUZA, J. F. C. D.; SANTOS, G. C. Armadilhas do Letramento Digital: A necessidade de comptência para a recuperação da informação. Campinas: Faculdade de Educação/Universidade Estadual de Campinas, 2007.

PIMENTA, S. G. Pedagogia: sobre diretrizes curriculares. Fórum Nacional de Pedagogia, Belo Horizonte, 2004.

Pedagogia, Ciência da Educação? 6. ed. São Paulo: Cortez, 2011. 
PRENSKY, M. On the horizon (NCB University Press). Digital Natives, Digital Immigrants, 9, out. 2001.

ROLDÃO, M. D. C. Função docente: natureza e construção do conhecimento profissional. Revista Brasileira de Educação, v. 2, 2007. p. 94 - 103.

SACRISTÁN, J. G. Consciência e ação sobre a prática como libertação profissional dos professores. In: NÓVOA, A. Profissão Professor. Porto: Porto Editora, 1995.

SANTOS, D. B. Avaliação de habilidades de inclusão digital: uma proposta de instrumento de pesquisa. Brasília: Instituto de Ciências Exatas, Departamento de Ciência da Computação, Universidade de Brasília, 2007.

SANTOS, M. L. Do giz à Era Digital. São Paulo: Zouk, 2003.

SAVIANI, D. Pedagogia: o espaço da educação na universidade. Caderno de Pesquisa, São Paulo, 37, p. 99 - 134, 2007.

SAVIANI, D. A Pedagogia no Brasil: história e teoria. 2. ed. Campinas, SP: Autores Associados, 2012.

SILVA, H. et al. Inclusão Digital e educação para a competência informacional: uma questão de ética e cidadania. Brasília: Ciência da Informação/UFBA, v. 34, 2005.

SILVA, K. A. C. P. C. D. A formação de professores na perspectiva críticoemancipadora. Revista Linhas Críticas, Brasília, v. 17, 2011.

SILVA, Obdália Santana Ferraz. Entre o plágio e a autoria: qual o papel da universidade? Rev. Bras. Educ., Rio de Janeiro, v. 13, n. 38, p. 357-368, Ago. 2008 .Disponível em: <http://www.scielo.br/scielo.php?script=sci_arttext\&pid=S141324782008000200012\&lng=en\&nrm=iso >. Acesso em: 22 abr. 2016.

UNB. Faculdade de Educação. Projeto Acadêmico do Curso de Pedagogia, 2002. Disponível em: <http://www.fe.UnB.br/images/graduacao/PROJETO\%20ACADEMICO\%20\%20atualizado\%20-\%20FE\%20COM\%20ALTERACOES\%20ATE\%20\%2016-122010.pdf>. Acesso em: 9 fev. 2015.

UNB. Faculdade de Educação. Projeto Pedagógico do Curso de Pedagogia, 2012. Disponível <http://www.fe.UnB.br/images/noticias/2014/files/Minuta\%20PPP.pdf>. Acesso em: 9 fev. 2015.

WERTHEIN, J. A sociedade da informação e seus desafios. Ci. Inf., Brasília, 29, ago. 2000. Disponível em: www.scielo.br/scielo.php?script=sci_arttext\&pid=S010019652000000200009\&lng=en\&nrm=iso. Acesso em: 16 mai. 2015. 
XAVIER, A. C. D. S. Letramento digital e ensino. In: SANTOS, C. F. Alfabetização e letramento: conceitos e relações. 1. ed. Belo Horizonte: Autêntica, 2007.

YIN, R. K. Estudo de caso: planejamento e métodos. 3. ed. Porto Alegre: Bookman, 2005.

\title{
APÊNDICE A - QUESTIONÁRIO DE PESQUISA
}

\author{
QUESTIONÁRIO DE PESQUISA \\ Universidade de Brasília - UnB / Faculdade de Educação \\ Programa de Pós-Graduação em Educação
}

Mestrando: Diego Viana Porto

Orientador: Prof. Dr. Gilberto Lacerda Santos

Linha de Pesquisa: ETEC - Educação Tecnologias e Comunicação

Agradecemos sua colaboração em participar da pesquisa que visa analisar se o curso de Pedagogia da Universidade de Brasília promove a inclusão digital de seus alunos, proporcionando uma atividade docente mediada pelas novas tecnologias e para uma sociedade cada vez mais digital.

Salientamos a importância de sua participação para elucidar aspectos referentes a esta temática, portanto o/a convidamos a emitir opinião, preenchendo questionário abaixo de acordo com a concordância aos itens propostos.

Destacamos que suas respostas serão tratadas com absoluto sigilo e anonimato e que sua participação é voluntária. Ao iniciar o preenchimento do formulário você estará concordando em participar dessa pesquisa. Caso queira desistir em algum momento, poderá fazê-lo sem qualquer prejuízo para você.

Informamos que para participar desta pesquisa é necessário ser aluno(a) do curso presencial de Pedagogia da UNB e estar matriculado no oitavo período. Desde já nos colocamos à disposição para quaisquer esclarecimentos pelo email: pedagogotecnologia@gmail.com

Siga a orientação de cada questão para a resposta mais apropriada. Lembre-se de que a indicação de uma resposta se dá pela marcação da caixa, $\square$,que segue em cada opção, $(a, b, c, d, e t c$.$) .$

\section{TEMA: TECNOLOGIAS NA FORMAÇÃO DO PEDAGOGO}

Questão 1 - A Faculdade de Educação disponibiliza aos alunos: (Assinale quantas opções forem necessárias)
a. $\square$ Acesso ao computador (laboratório de informática, lan house, etc.).
b. $\square$ Acesso à internet (Wi-fi, cabeada, etc.).
c. $\square$ Serviços on-line (Informações, comprovantes, declarações, calendário, etc.).
d. $\square$ Acesso a dispositivos digitais (webcam, caixa de som, microfone, etc.).
e. $\square$ Sala de multimídia, videoconferência. 
Questão 2 - Quais as condições, em geral, de funcionamento dos equipamentos tecnológicos (computador, data-show, TV, etc.) utilizados durante a graduação?

a. $\square$ Atualizados e bem conservados.

b. $\square$ Atualizados, mas mal conservados.

c. $\square$ Desatualizados, mas bem conservados.

d. $\square$ Desatualizados e mal conservados.

Questão 3 - Acesso aos microcomputadores/internet da universidade para desenvolver as atividades propostas em seu curso:

a. $\square$ Acesso pleno.

b. $\square$ Acesso limitado.

c. $\square$ Impossibilidade de acesso.

d. $\square$ O curso não necessita de microcomputadores.

Questão 4 - A faculdade proporcionou ou disponibilizou, de alguma forma, sua formação para trabalhar com as TDICE? (Assinale quantas opções forem necessárias)

a. $\square$ Através de mini-cursos.

b. $\square$ Através de oficinas.

c. $\square$ Através de cursos.

d. $\square$ Através de disciplinas do curso.

e. $\square$ Não proporcionou minha formação para trabalhar com as tecnologias.

f. $\square$ De outra forma:

Questão 5 - Você cursou alguma disciplina que diz respeito à teoria da temática (Educação e Tecnologias)?
a. $\square$ Sim, obrigatória.
b. $\square$ Sim, optativa.
c. $\square$ Não.

Questão 6 - Você cursou alguma disciplina que versou sobre a prática didática docente com as novas tecnologias?
a. $\square$ Sim, obrigatória
b. $\square$ Sim, optativa.
c. $\square$ Não.

Questão 7 - Qual(is) das disciplinas ofertadas na UNB/FE você cursou? (Assinale quantas opções forem necessárias)
a. $\square$ Ensino de Ciências e Tecnologia 1.
b. $\square$ Práticas Mediáticas na Educação.
c. $\square$ Linguagens Audiovisuais na Educação.
d. $\square$ Ensino de Ciência e Tecnologia 2.
e. $\square$ Educação a Distância (MTC).
f. $\square$ Educação e Linguagens Tecnológicas (MTC).
g. $\square$ Educação Hipertextual (MTC).
h. $\square$ Gestão de Sistemas de EAD (PAD).
i. $\square$ Informática Aplicada à Administração da Educação (PAD).
j. $\square$ Pesquisa em Educação a Distância (MTC).
k. $\square$ Seminário Tecnologias na Educação (MTC).
1. $\square$ Tecnologia e Educação (MTC).
m. $\square$ Tecnologia na Educação Especial (TEF).
n. $\square$ Tópicos Especiais em Ensino de Ciência e Tecnologia (MTC).
o. $\square$ Usos de TV/Vídeo na Escola (MTC).
p. $\square$ Computadores na Educação. 
q. $\square$ Outra disciplina que aborde a temática (Tecnologia e Educação).

Questão 8 - Está matriculado(a) ou já cursou alguma disciplina ofertada integralmente ou parcialmente a distância?

a. $\square$ Sim.

Questão 9 - Você acredita ser necessária uma disciplina que trate das novas tecnologias e sua relação com a educação na graduação?
a. $\square$ Sim.
b. $\square$ Não.
c. $\square$ Indiferente.
d. $\square$ Não sei.

Questão 10 - Os professores proporcionavam uma didática mediada pelas TDICE?
a. $\square$ Sim, todos.
b. $\square$ Sim, $65 \%$ dos professores.
c. $\square$ Sim, $50 \%$ dos professores.
d. $\square$ Sim, $20 \%$ dos professores.
e. $\square$ Não proporcionavam.

Questão 11 - Quais dos recursos, equipamentos eram utilizados didaticamente pelos professores? (Assinale quantas opções forem necessárias)
a. $\square$ Internet.
b. $\square$ Computador.
c. $\square$ Data-show, projetor multimídia.
d. $\square$ Televisão.
e. $\square$ Webcam.
f. $\square$ Microfone.
g. $\square$ Caixa de som.
h. $\square$ Tablet.
i. $\square$ Lousa digital.
j. $\square$ Smartphone.
k. $\square$ Outros:

Questão 12 - Quais desses recursos são utilizados pelos professores para se comunicarem com os alunos fora da sala de aula? (Assinale quantas opções forem necessárias)
a. $\square$ Email.
b. $\square$ Blog.
c. $\square$ Facebook.
d. $\square$ Whatzap.
e. $\square$ Skype.
f. $\square$ Chats.
g. $\square$ Twitter.
h. $\square$ Sistema de Gerenciamento Acadêmico.
i. $\square$ Não são utilizados.
j. $\square$ Outro:

Questão 13 - Quais dos itens listados foram exigidos de você a participação ou criação perante as demandas do curso (professores, trabalhos, atividades escolares): (Assinale quantas opções forem necessárias)
a. $\square$ Email.
b. $\square$ Rede social (facebook, instagram, Google +, etc.).
c. $\square$ Lista de discussão, fórum ou comunidade virtual.
d. $\square$ Canal de comunicação (blog, glog, canal de vídeo, site pessoal, etc.). 
Questão 14 - Quais dos softwares listados foi necessária a sua utilização pela necessidade imposta pelas demandas do curso (professores, trabalhos, atividades escolares)? (Assinale quantas opções forem necessárias)

a. $\square$ Editor de Texto (word, writer, etc.).

b. $\square$ Planilhas Eletrônicas (excel, calc, etc.).

c. $\square$ Criador de Slides (power pointer, impress, etc.).

d. $\square$ Navegador de Internet (internet explorer, mozilla, chrome, etc.).

e. $\square$ Editor de Imagens (photoshop, paint, ginp, corel, etc.).

f. $\square$ Editor de Vídeos (movie maker, virtualdub, vegas, etc).

g. $\square$ Jogos.

h. $\square$ Gravadores de CD/DVD (nero, brasero, express burn, etc.).

i. $\square$ Outro:

Questão 15 - Com que finalidades didático-pedagógicas as TDICE (computadores, internet, tablets, etc.) são utilizadas pelos professores? (Assinale quantas opções forem necessárias)

a. $\square$ Introduzir conteúdo.

b. $\square$ Ressignificar conteúdos.

c. $\square$ Instrumento de pesquisa.

d. $\square$ Esclarecer dúvidas.

e. $\square$ Estimular debates.

f. $\square$ Incentivar criatividade.

g. $\square$ Fazer demonstração de como as utilizar em suas atividades acadêmicas.

Questão 16 - Como você avalia a relação, utilização e propagação das TDICE na Faculdade de Educação (instituição, professores)?
a. $\square$ Excelente.
b. $\square$ Boa.
c. $\square$ Regular.
d. $\square$ Ruim.
e. $\square$ Péssima.
f. $\square$ Não sei avaliar.

Questão 17 - Em sua opinião, para que houvesse uma melhoria na utilização das novas tecnologias em sua graduação seria necessário: (Assinale quantas opções forem necessárias)
a. $\square$ Equipamentos de qualidade.
b. $\square$ Formação dos professores.
c. $\square$ Espaço disponível para laboratórios.
d. $\square$ Profissional especializado nas novas tecnologias.
e. $\square$ Não acho necessário.
f. $\square$ Não sei responder.
g. $\square$ Outros

Questão 18 - A sua formação no curso de Pedagogia te possibilitou:

a. $\square$ Ter conhecimentos básicos para lidar com as TDICE.

b. $\square$ Ter conhecimentos avançados para lidar com as TDICE.

c. $\square$ Não propiciou minha formação para lidar com as TDICE.

Questão 19 - Você se sente preparado para propiciar uma atividade docente mediada pelas novas tecnologias:
a. $\square$ Sim.
b. $\square$ Não.
c. $\square$ Não sei responder. 
Questão 20 - Em relação à inserção das novas tecnologias na sala de aula:

a. $\square$ Sou favorável.

b. $\square$ Sou favorável, mas com restrições (Conforme modalidade de ensino, série, turma, objetivo pedagógico, etc.).

c. $\square$ Não sou favorável.

d. $\square$ Não sei responder.

Para finalizar, gostaríamos de conhecê-lo/la um pouco melhor para podermos caracterizar os participantes desta pesquisa.

Por favor, responda aos itens que se seguem.

Questão 21 - Gênero:

a. $\square$ Masculino

b. $\square$ Feminino

Questão 22 - Faixa etária

a. $\square$ Até 22 anos

b. $\square$ De 23 a 27 anos

c. $\square$ De 28 a 33 anos

d. $\square$ Acima de 33 anos

Questão 23 - Deseja seguir carreira como professor(a):

a. $\square \mathrm{Sim}$

b. $\square$ Não

Questão 24 - Está matriculado em qual turma de Pedagogia:

a. $\square$ Diurno

b. $\square$ Noturno

\section{Obrigada por sua participação!}

1. Todas as informações coletadas através deste questionário são sigilosas e serão usadas exclusivamente pelo pesquisador Diego Viana Porto e pelo Prof. Dr. Gilberto Lacerda Santos, do Programa de Pós-Graduação em Educação da FE/UNB.

2. Todas as informações coletadas nas entrevistas serão mantidas sob sigilo e os entrevistados não serão identificados. Por favor, preencha seus dados abaixo.

NOME:

E-MAIL:

TELEFONES:

Em uma fase posterior da pesquisa, alguns alunos serão selecionados para participar de uma entrevista para aprofundamento de estudo na temática abordada. Ao se levar em consideração a importância da pesquisa, você deseja participar:

a. $\square$ Sim

b. $\square$ Não 


\section{APÊNDICE B - ROTEIRO DA ENTREVISTA SEMIESTRUTURADA}

\begin{tabular}{|c|c|c|}
\hline TEMA & $\begin{array}{l}\text { ROTEIRO DE } \\
\text { PERGUNTAS }\end{array}$ & OBJETIVO \\
\hline $\begin{array}{l}\text { Tecnologias } \\
\text { Educação. }\end{array}$ & $\begin{array}{l}\text { - } \quad \text { Qual a sua percepção em relação à } \\
\text { inserção das TDICE na educação? } \\
\text { - } \quad \text { Para você, qual é o perfil adequado } \\
\text { para o professor do século XXI? } \\
\text { - O que é ser incluído digitalmente? }\end{array}$ & $\begin{array}{l}\text { Perceber qual a } \\
\text { percepção dos alunos do } \\
\text { curso de Pedagogia em } \\
\text { relação à inserção das } \\
\text { TDICE na educação. }\end{array}$ \\
\hline $\begin{array}{l}\text { Tecnologias } \\
\text { Sala de Aula. }\end{array}$ & $\begin{array}{l}\text { - O que pensa sobre o emprego das } \\
\text { TDICE dentro da sala de aula? } \\
\text { - Quais são os pontos positivos? E os } \\
\text { pontos negativos? } \\
\text { - Existem restrições? Algumas } \\
\text { indicações? }\end{array}$ & $\begin{array}{l}\text { Perceber qual a } \\
\text { percepção dos alunos em } \\
\text { relação à inserção das } \\
\text { TDICE na sala de aula. }\end{array}$ \\
\hline $\begin{array}{l}\text { Tecnologias } \\
\text { Docência. }\end{array}$ & $\begin{array}{l}\text { - Você se sente confortável para uma } \\
\text { didática mediada pelas TDICE? } \\
\text { - É capaz de desenvolver uma } \\
\text { didática mediada pelas novas } \\
\text { tecnologias? } \\
\text { - Você se acha capaz de propiciar a } \\
\text { inclusão digital de seus alunos? }\end{array}$ & 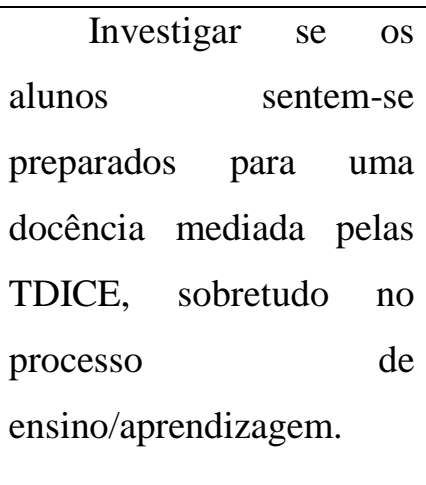 \\
\hline
\end{tabular}




\title{
APÊNDICE C - TERMO DE CONSENTIMENTO LIVRE E ESCLARECIDO
}

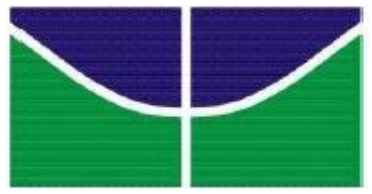

\author{
Universidade de Brasília - UNB / Faculdade de Educação \\ Programa de Pós-Graduação em Educação
}

\section{TERMO DE CONSENTIMENTO LIVRE E ESCLARECIDO}

Prezado(a) participante:

Sou estudante do programa de mestrado na Faculdade de Educação da Universidade de Brasília. Estou realizando uma pesquisa sob supervisão do professor Dr. Gilberto Lacerda Santos, cujo objetivo é analisar se o curso de Pedagogia da Universidade de Brasília proporciona aos seus alunos a formação que possibilite uma docência mediada pelas TDICE.

Sua participação envolve participar de uma entrevista, que será gravada se assim você permitir, e que tem a duração aproximada de vinte minutos. A participação nesse estudo é voluntária e se você decidir não participar ou quiser desistir de continuar em qualquer momento, tem absoluta liberdade de fazê-lo.

Na publicação dos resultados desta pesquisa, sua identidade será mantida no mais rigoroso sigilo. Serão omitidas todas as informações que permitam identificá-lo(a). Mesmo não tendo benefícios diretos em participar, indiretamente você estará contribuindo para a compreensão do fenômeno estudado e para a produção de conhecimento científico.

Quaisquer dúvidas relativas à pesquisa poderão ser esclarecidas pelo pesquisador no telefone (38) 99763658 ou email: diegovipo@ gmail.com.

\section{Consentimento Livre e Esclarecido}

Tendo em vista os itens acima apresentados, eu, de forma livre e esclarecida, manifesto meu consentimento em participar da pesquisa. Declaro que recebi cópia deste termo de consentimento, e autorizo a realização da pesquisa e a divulgação dos dados obtidos neste estudo.

Assinatura do Pesquisador/ Diego Viana Porto

Assinatura do Participante

Brasília-DF, 2015 